ANDRÉ LUIZ VEIGA GIMENES

\title{
AGREGAÇÃO DE VALOR À ENERGIA ELÉTRICA ATRAVÉS DA GESTÃO INTEGRADA DE RECURSOS
}

Dissertação apresentada à Escola Politécnica da Universidade de São Paulo para obtenção do título de Mestre em Engenharia.

São Paulo

2000 


\section{ANDRÉ LUIZ VEIGA GIMENES}

\section{AGREGAÇÃO DE VALOR À ENERGIA ELÉTRICA ATRAVÉS DA GESTÃO INTEGRADA DE RECURSOS}

Dissertação apresentada à Escola Politécnica da Universidade de São Paulo para obtenção do título de Mestre em Engenharia.

Área de Concentração:

Sistemas de Potência

Orientador:

Prof. Dr. Lineu Belico dos Reis

São Paulo

2000 


\section{Gimenes, André Luiz Veiga}

Agregação de Valor à Energia Elétrica Através da Gestão Integrada de Recursos, São Paulo, 2000. 239p.

Dissertação (Mestrado) - Escola Politécnica da Universidade de São Paulo. Departamento de Engenharia de Energia e Automação Elétricas.

1. Energia Elétrica 2. Infra-Estrutura - Universidade de São Paulo. Escola Politécnica. Departamento de Engenharia de Energia e Automação Elétricas. 
À Karla, minha companheira nesta e em outras empreitadas da vida, aos meus pais e meu irmão, sempre firmes na batalha... 


\section{AGRADECIMENTOS}

Ao Prof. Dr. Luiz Cláudio Ribeiro Galvão, que criou, desde o princípio, condições para que este trabalho se tornasse possível, respaldando, incentivando e principalmente acreditando nesta iniciativa.

Ao Prof. Dr. Fernando Selles Ribeiro, chefe do Departamento de Engenharia de Energia e Automação Elétricas da Escola Politécnica da Universidade de São Paulo, que igualmente manteve 0 apoio ao desenvolvimento deste trabalho.

Ao Prof. Dr. Lineu Belico dos Reis, que orientou esta dissertação de maneira aberta e colaborativa, contribuindo sempre com sua experiência e conhecimentos e, acima de tudo, permitindo e incentivando o desenvolvimento das minhas próprias idéias.

Ao amigo Prof. Dr. Miguel Edgar Morales Udaeta, especialista na arte da reflexão, que, com seu senso de equipe, tem contribuído de maneira decisiva ao meu aprimoramento profissional e pessoal.

Aos meus amigos, Alden Uehara Antunes e Cláudio Elias Carvalho, que, quase sem perceberem, foram e têm sido fundamentais no desenrolar dos meus trabalhos.

À CAPES pelo apoio financeiro dado através da bolsa de estudos. 


\section{LISTA DE FIGURAS}

$\begin{array}{lr}\text { Figura 2.1: Infra-Estrutura para Energia Elétrica } & 8\end{array}$

$\begin{array}{ll}\text { Figura 2.2: Infra-Estrutura para Água e Saneamento } & 8\end{array}$

$\begin{array}{ll}\text { Figura 2.3: Infra-Estrutura para Transporte } & 9\end{array}$

Figura 2.4: Infra-Estrutura para Tratamento do Lixo 9

Figura 2.5: Infra-Estrutura para Telecomunicações 10

Figura 3.1: Aceitabilidade e Sustentabilidade: Viabilização de Projetos 35

Figura 4.1: Diagrama Básico da Gestão Integrada de Recursos $\quad 59$

Figura 4.2: Alteração no Perfil de Investimentos em Infra-Estrutura 62

Figura 4.3: Vertentes Básicas da Sustentabilidade $\quad 81$

Figura 4.4: Sinergia a Partir da Água $\quad 92$

Figura 4.5: Sinergia a Partir da Eletricidade $\quad 93$

Figura 4.6: Sinergia a Partir do Tratamento do Lixo 93

Figura 4.7: Sinergia Entre Eletricidade e Telecomunicações 94

$\begin{array}{ll}\text { Figura 4.8: Joint Venture por Desmembramento } & 103\end{array}$

Figura 4.9: Estrutura de Comparação de Investimentos Convencionais e Segundo $\begin{array}{ll}\text { a GIR } & 107\end{array}$

$\begin{array}{ll}\text { Figura 4.10: Análise de Possíveis Vantagens Econômicas } & 109\end{array}$

$\begin{array}{ll}\text { Figura 4.11: Perdas de Capital em Infra-Estrutura } & 112\end{array}$

Figura 5.1: Gráfico de Médias Mensais Pluviométricas do Município de Cruzália 173 


\section{LISTA DE TABELAS}

Tabela 2.1: Cobertura de Infra-Estrutura nos Países 22

Tabela 2.2: Domicílios por Condição de Saneamento e Luz Elétrica 22

Tabela 4.1: Qualificação de Impactos nos Indicadores Sociais 61

Tabela 4.2: Qualificação de Impactos no Resultado Empresarial 61

Tabela 4.3: Custos Incidentes 69

Tabela 4.4: Benefícios Incidentes

Tabela 4.5: Características Empresariais dos Componetes da Infra-Estrutura $\quad 76$

Tabela 4.6: Atuação x Necessidades $\quad 77$

Tabela 4.7: Possíveis Indicadores e Beneficiados $\quad 78$

Tabela 4.8: Atores Envolvidos x Tipo de Investimento x Tipo de Benefício $\quad 79$

Tabela 4.9: Características do Tipo de Propriedades e Operação da Infra-Estrutura $\quad 88$

Tabela 4.10: Coeficiente Técnico Intersetorias - IBGE 1995

Tabela 4.11: Matriz de Leontief $\quad 127$

Tabela 4.12: Emprego e Coeficiente de Geração de Empregos IBGE 1980

Tabela 4.13: Estrutura de Matriz de Avaliação de Impactos 142

Tabela 5.1: Números Característicos do Vale do Médio Paranapanema $\quad 147$

Tabela 5.2: Caracterização Fundiária da Região do CIERGA, $1985 \quad 148$

Tabela 5.3: Vazões Características dos Rios da Região do MPP $\quad 150$

Tabela 5.4: Custos da Geração Propriamente Dita, Sem Acréscimos 155

Tabela 5.5: Taxas, Encargos e Outros Acréscimos - Venda à Concessionária $\quad 155$

Tabela 5.6: Resultados para um Mercado Competitivo, Sem Alavancagem 158

Tabela 5.7: Viabilidade Econômica de um Estabelecimento Produtor de Grãos de 50 ha, na Região 161

Tabela 5.8: Viabilidade Econômica de um Estabelecimento Produtor de Grãos de 75

ha, na Região 161

Tabela 5.9: Viabilidade Econômica de um Estabelecimento Produtor de Grãos de 100 ha, na Região 162

Tabela 5.10: Média Pluviométrica Mensal do Município de Cruzália 173

Tabela 5.11: Estimativas Mensais da Necessidade de Irrigação $\quad \mathbf{1 7 4}$

Tabela 5.12: Custos Mensais de Energia Elétrica ( $p / 50$ ha) 176

$\begin{array}{ll}\text { Tabela 5.13: Custos e Lucratividade do Cultivo da Pupunha } & 178\end{array}$

Tabela 5.14: Rendas Mensais Proporcionadas pelo Cultivo da Pupunha $\quad 179$

Tabela 5.15: Características Físicas e Sociais do Município de Cruzália 202

Tabela 5.16: Estimativa de Arrecadação de Impostos 206

Tabela 5.17: Reinvestimento para Ampliação do Projeto 221 


\section{LISTA DE ABREVIATURAS}

$\begin{array}{ll}\text { ACC } & \text { Análise dos Custos Completos } \\ \text { ANA } & \text { Agência Nacional de Águas } \\ \text { ANEEL } & \text { Agência Nacional de Energia Elétrica } \\ \text { BATNEEC } & \text { Best Alternative Not Entailing Excessive Costs } \\ \text { BNDES } & \text { Banco Nacional de Desenvolvimento Econômico e Social } \\ \text { CETESB } & \text { Companhia de Tecnologia de Saneamento Ambiental } \\ \text { CFCs } & \text { Clorofluorcarbonos } \\ \text { CIERGA } & \text { Consórcio Intermunicipal da Região do Governo de Assis } \\ \text { COFINS } & \text { Contribuição para o Financiamento da Seguridade Social } \\ \text { CONAMA } & \text { Conselho Nacional do Meio Ambiente } \\ \text { CS } & \text { Contribuição Social } \\ \text { EGF } & \text { Empréstimo do Governo Federal } \\ \text { ELETROBRAS } & \text { Centrais Elétricas do Brasil SA } \\ \text { EIA } & \text { Estudo de Impacto Ambiental } \\ \text { FC } & \text { Fator de Compensação à Usina } \\ \text { IBGE } & \text { Instituto Brasileiro de Geografia e Estatística } \\ \text { IBAMA } & \text { Instituto Brasileiro do Meio Ambiente e dos Recursos Naturais Renováveis } \\ \text { IPTU } & \text { Impostos Predial e Territorial Urbano } \\ \text { IR } & \text { Imposto de Renda } \\ \text { ISS } & \text { Imposto Sobre Serviços } \\ \text { MP } & \text { Material Particulado } \\ \text { MPP } & \text { Região do Vale do Médio Paranapanema } \\ \text { PCH } & \text { Pequenas Centrais Hidrlétricas } \\ \text { PIB } & \text { Produto Interno Bruto } \\ \text { PNB } & \text { Produto Nacional Bruto } \\ \text { PNUD } & \text { Programa das Nações Unidas para o Desenvolvimento } \\ \text { RGR } & \text { Reserva Geral de Reversão } \\ \text { RIMA } & \text { Relatório de Impacto Ambiental } \\ & \end{array}$




\section{RESUMO}

Há algum tempo, a energia elétrica tem sido pensada como um fator de fomento ao desenvolvimento de regiões carentes. No entanto, a experiência tem mostrado que, embora seja realmente necessária, a presença da energia elétrica, por si só não é suficiente para alcançar tal objetivo.

Neste contexto, o presente trabalho aborda a disponibilização da energia elétrica de forma integrada em um cenário mais amplo, o da infra-estrutura, abrangendo o Transporte, a Água e Saneamento, o Tratamento do Lixo e as Telecomunicações, com vistas a criar uma base sólida para alavancar o desenvolvimento.

Para tanto, propõe a abordagem da Gestão Integrada de Recursos GIR, que é balizada pelo equilíbrio entre os aspectos econômico, social e ambiental dos empreendimentos, visando a provisão de infra-estrutura com vistas ao desenvolvimento sustentável de regiões carentes.

Esta metodologia, desenvolvida no contexto de uma visão abrangente e integrada da infra-estrutura, permite a identificação de sinergias e potencialidades entre os seus componentes, bem como de possíveis parcerias entre os envolvidos. Dessa forma espera-se estabelecer vantagens econômicas, sociais e ambientais na provisão de infra-estrutura pelo setor privado sob a ação do Estado, não mais como investidor e administrador, mas como ente regulador.

Nesta gestão, salienta-se a importância da atuação do Setor Público no sentido de criar mecanismos regulatórios diferenciados, que tornem os investimentos em infra-estrutura atrativos ao investidor privado, ao mesmo tempo em que estabelecem e permitem a fiscalização do cumprimento das metas sociais e de preservação ambiental. 


\begin{abstract}
Electrical energy has been considered like a fomentation factor to the poorest regions. The experience has shown that electrical energy is really necessary but it's not sufficient to guarantee a development basis.

In such a context, this work focuses the integration of electrical energy within other component of the infrastructure, including Transportation, Water and Sanitation, Waste Disposal and the Telecommunications, in order to establish a strong basis for development.

For that, the work proposes the approach Integrated Resources Management -IRM, that is based on the balance of the economic, social and environmental aspects of the projects, in order to guarantee the required infrastructure basis for the sustainable development of the poorest regions.

In this type of management, it is emphasized the importance of the Public Sector, in order to create new regulatory mechanisms that make the infrastructure investments more attractive to the Private Sector, at the same time in witch establish and allow the monitoring of the social goals and of the environmental preservation.

This methodology is developed within a wide and integrated vision of the infrastructure that allows the identification of synergies and potentialities of its components, and the establishment of partnerships of involved parties. This approach is expected to establish economic, social and environmental advantages in the infrastructure provision by the private sector, under the regulatory State action.
\end{abstract}




\section{SUMÁRIO}

Lista de Figuras

Lista de Tabelas

Lista de Abreviaturas

Resumo

Abstract

1. INTRODUÇÃO.................................................................................. 1

1.1 A importância da infra-estrutura para um Desenvolvimento Sustentável.............. 2

1.2 A Energia Elétrica no contexto da Infra-estrutura.................................................... 3

1.3 A Gestão Integrada de Recursos....................................................................... 3

1.4 Roteiro do Trabalho.................................................................................................

2. INFRA-ESTRUTURA, MEIO AMBIENTE E DESENVOLVIMENTO SUSTENTÁVEL - A ENERGIA ELÉTRICA

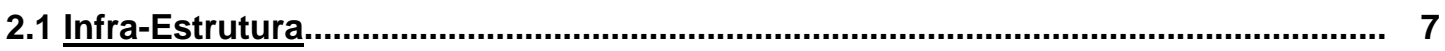

2.2 Infra-Estrutura e a Interação com o Meio Ambiente................................................ 10

2.2.1 Água e Saneamento............................................................................. 11

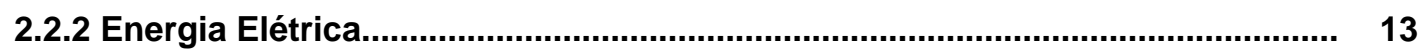

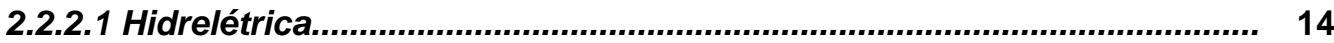

2.2.2.2 Termelétrica..................................................................................... 15

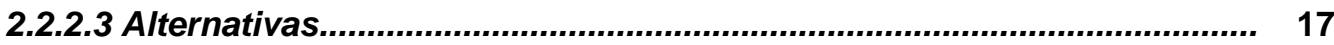

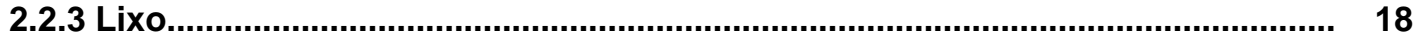

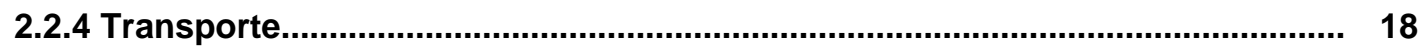

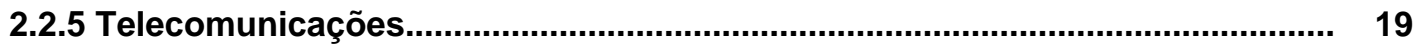

2.3 Infra-Estrutura e o Desenvolvimento Sustentável.................................................... 20

2.3.1 Considerações Quanto aos Investimentos em Infra-Estrutura......................... 25

2.3.2 Considerações sobre a Inserção da Infra-Estrutura em um Ambiente de

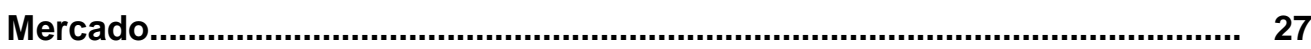

2.4 A Energia Elétrica no Contexto Global da Infra-estrutura........................................... 30

\section{SUSTENTABILIDADE E ACEITABILIDADE - A VIABILIZAÇÃO DE PROJETOS}

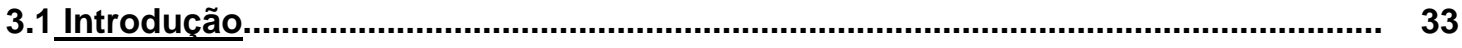

3.2 Sustentabilidade: Barreiras e Incentivos.................................................................. 36 
3.2.1 O Papel das Partes Políticas...................................................................... 41

3.2.2 Padrão de Vida........................................................................................ 43

3.2 Aceitabilidade: Variável Básica para Viabilizacão de Projetos................................. 44

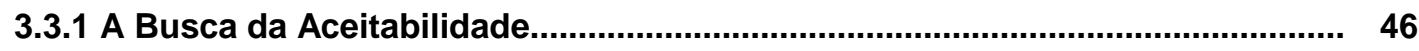

3.3.2 O Processo de Planejamento.......................................................................... 48

3.3 A Viabilizacão dos Projetos Através de uma GIR - Gestão Integrada de

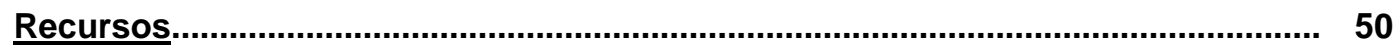

\section{A PROPOSTA DA GESTÃO INTEGRADA DE RECURSOS}

4.1 A Base, os Conceitos, o Desenho...................................................................... 53

4.1.1 Base e Conceitos....................................................................................... 53

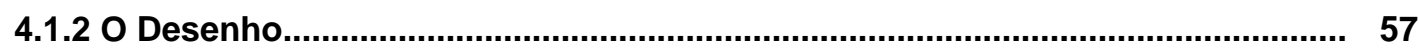

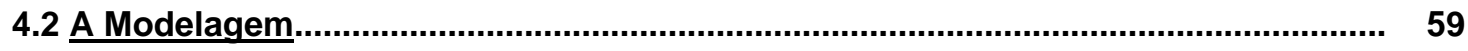

4.2.1 Leque de Opções.............................................................................. 60

4.2.1.1 Impactos nos Indicadores Sociais ...................................................... 62

4.2.1.2 Impactos no Resultado Empresarial................................................ 67

4.2.2 Análise dos Componentes da Infra-Estrutura Economicamente Atraentes.... 68

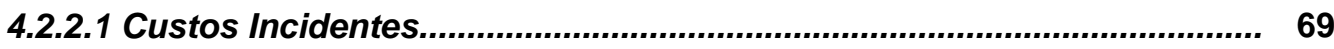

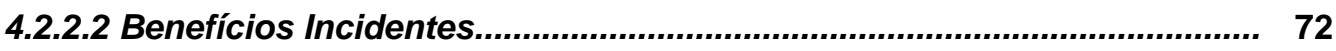

4.2.3 Análise dos Componentes Socialmente Necessários.................................. 77

4.2.3.1 Investidores $x$ Beneficiados................................................................. 78

4.2.4 Definição do Tipo de Atuação Privada e Pública............................................ 83

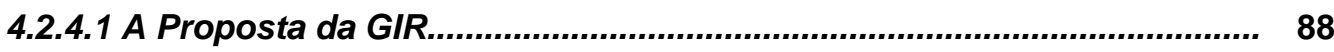

4.2.5 Identificação da Sinergia (Construtiva e/ou Operativa) entre os Componentes da Infra-Estrutura ............................................................ 91

4.2.6 Definição do Escopo.............................................................................. 94

4.2.7 Definição do Tipo de Parceria..................................................................... 94

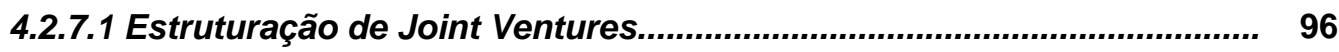

4.2.7.2 Métodos de Divisão e Controle........................................................ 98

4.2.7.3 Técnicas Avançadas de Estruturação............................................... 102

4.2.7.4 Considerações Finais Acerca das Parcerias....................................... 103

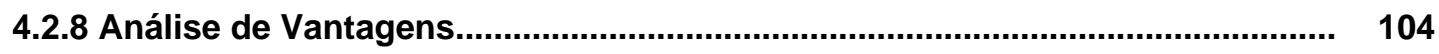

4.2.8.1 Análise das Vantagens Econômicas................................................ 105

4.2.8.2 Análise das Vantagens Sociais........................................................ 112

4.2.8.3 Análise das Vantagens Ambientais................................................. 113

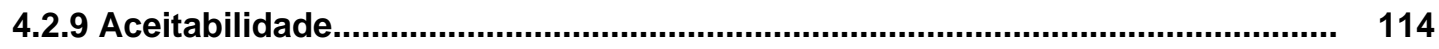

4.3 Metodologia, Métodos, Coleta de Dados / Informacões......................................... 115

4.3.1 Exemplos de Metodologias de Análise Econômica........................................ 1115 
4.3.1.1 Metodologias para Análise Técnico-Econômica de um Projeto de uma $\mathrm{PCH}$.

4.3.1.2 Metodologias para Análise Técnico-Econômica da Produção Agrícola da Pupunha.

4.3.2 Exemplos de Metodologias de Análise Social de Projetos. 123

4.3.2.1 Indicadores. 124

4.3.2.2 Método da Matriz de Leontief. 125

4.3.3 Exemplos de Metodologias de Análise Ambiental de Projetos. 128

4.3.3.1 Estudo de Impacto Ambiental. 129

4.3.3.2 Método da Matriz de Leontief. 132

4.3.4 Coleta de Dados e Informações 133

4.4 Avaliação de Alternativas.. 134

4.4.1 Método da Avaliação dos Custos Completos. 135

4.4.1.1 Triagem Inicial dos Recursos. 136

4.4.1.2 Metodologia de Avaliação. 137

4.4.1.3 Seleção dos Recursos.. 138

4.4.1.4 Avaliação dos Custos Completos. 139

4.4.1.5 Avaliação Final dos Custos Completos. 142

4.4.1.6 Plano Indicativo para as Alternativas. 143

5. GIR - ESTUDO DE CASO

5.1 O Caso Estudado: Energia Elétrica, Áqua / Irrigacão / Producão Agrícola. 144 5.1.1 O Problema Isolado. 144

5.1.2 A Gestão Integrada. 145

5.2 Caracterizacão da Região de Estudo: Médio Paranapanema - MPP. 147

5.2.1 Características Sócio-Econômicas e Fundiárias. 147

5.2.2 Características Físicas............................................................................ 148

5.2.2.1 Clima. 149

5.2.2.2 Solos. 149

5.2.2.3 Recursos Hídricos. 150

5.3 Energia Elétrica: Geração Através de uma PCH. 151

5.3.1 Dimensionamento 151

5.3.2 Análise de Viabilidade Econômica da PCH. 152

5.3.2.1 Valores de Referência / Dados Básicos. 152

5.3.2.2 Taxas e Encargos. 154

5.3.2.3 Avaliação Econômica Segundo a Prática Tradicional do Setor Elétrico. 
5.3.2.4 Investimento Efetuado no Contexto de Mercado competitivo, Sem Alavancagem

5.4 Água: O Uso para Irrigação e a Produção Agrícola............................................... 159

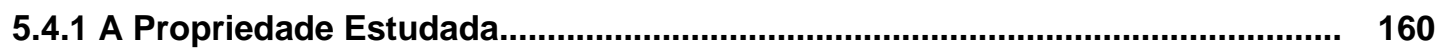

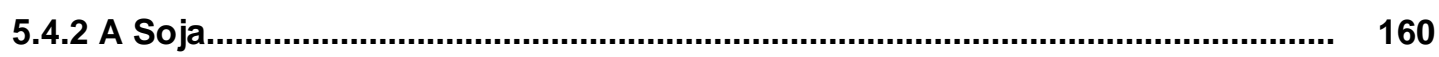

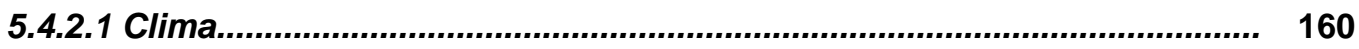

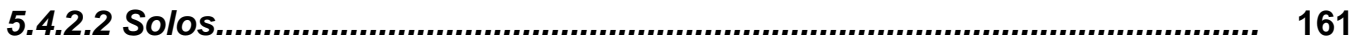

5.4.2.3 Adequação às Características da Região do Médio Paranapanema..... 161

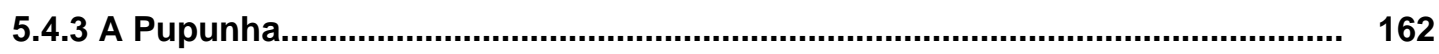

5.4.3.1 Potencial Econômico e de Mercado.................................................... 163

5.4.3.2 Clima............................................................................................. 164

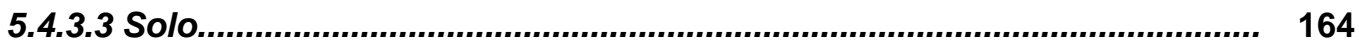

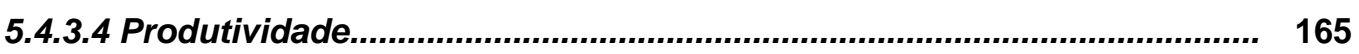

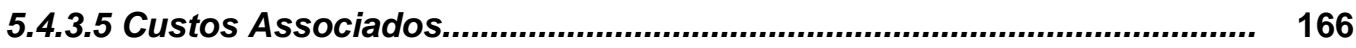

5.4.3.6 Comercialização.............................................................................. 166

5.4.3.7 Adequação às Características da Região do Médio Paranapanema...... 169

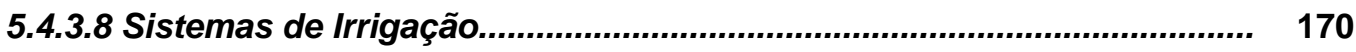

5.4.3.9 Análise de Viabilidade Econômica da Pupunha com o Sistema de Irrigação....................................................................................... 177

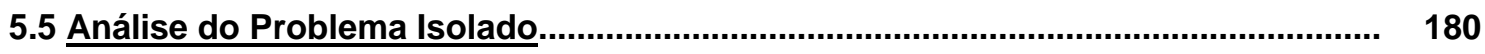

5.6 O Problema Segundo a Gestão Integrada de Recursos........................................ 181

5.6.1 Identificação dos Componentes................................................................... 182

5.6.2 A Nova Modelagem................................................................................ 184

5.6.2.1 Atividade Agrícola........................................................................ 184

5.6.2.2 Sustentabilidade no Uso da Água...................................................... 185

5.6.2.3 Compensação à PCH..................................................................... 192

5.6.3 Análise das Vantagens........................................................................... 198

5.6.3.1 Análise das Vantagens Econômicas.................................................... 198

5.6.3.2 Análise das Vantagens Sociais.................................................... 201

5.6.3.3 Análise das Vantagens Ambientais................................................ 210

5.6.4 A Consideração do Caso Proposto em um Horizonte de Planejamento 216

5.6.4.1 Plano de Ampliação do Projeto...................................................... 219

6. CONCLUSÕES E RECOMENDAÇÕES ….................................................................. 223

REFERÊNCIAS BIBLIOGRÁFICAS...................................................................... 227

ANEXO 


\section{INTRODUÇÃO}

O presente trabalho tem como objetivo analisar a energia elétrica inserida em um contexto mais amplo, o da disponibilização de infra-estrutura com vistas a um desenvolvimento sustentável.

Nesta análise são considerados os aspectos econômicos, sociais políticos e tecnológicos da disponibilização da infra-estrutura e sua relação com o meio ambiente.

O aspecto principal a que o trabalho estará voltado é o da facilitação da implantação da infra-estrutura, preferencialmente pelo setor privado.

Com este intuito foi proposta a abordagem chamada de Gestão Integrada de Recursos.

O conceito de Gestão Integrada de Recursos abrange a administração da disponibilização e operação de recursos diversos de forma integrada, com vistas ao Desenvolvimento Sustentável.

Dessa forma, os recursos, seus impactos, os entes afetados (sociedade, setores público e privado) e seus conflitos e interesses são administrados dentro de uma visão integrada, procurando estabelecer um equilíbrio entre os aspectos econômico, social, ambiental, político e tecnológico.

Acredita-se que deste equilíbrio advenham condições para que se possa dar passos na direção da sustentabilidade.

Uma breve apresentação dos principais conceitos utilizados neste trabalho é feita a seguir, assim como uma descrição do roteiro seguido em seu desenvolvimento. 


\subsection{A Importância da Infra-Estrutura para um Desenvolvimento}

\section{Sustentável}

A infra-estrutura desempenha um papel preponderante na busca do Desenvolvimento Sustentável.

Ela é a base para o desenvolvimento das atividades humanas e se relaciona diretamente com os aspectos principais do Desenvolvimento Sustentável: social, ambiental e econômico.

O desenvolvimento econômico é extremamente dependente da presença da infra-estrutura, sem a qual, a indústria e o comércio têm sua viabilidade e expansão comprometidas

Socialmente a infra-estrutura é fundamental para que haja condições de saúde e desenvolvimento pessoal, principalmente nos grandes centros urbanos onde a presença do saneamento básico é o condicionante principal da saúde pública.

Por fim, na questão ambiental, a infra-estrutura torna-se necessária primeiro por permitir o desenvolvimento econômico e social, sem o qual pode haver degradação ambiental. Segundo, por comportar componentes como o saneamento básico, sem os quais não há condições de preservação ambiental, além de outros componentes que, uma vez mal gerenciados, colaboram para piorar as condições ambientais. 


\subsection{A Energia Elétrica no Contexto da Infra-Estrutura}

A energia elétrica representa um papel preponderante no contexto global da infra-estrutura .

A sua presença não é condição suficiente para que haja 0 desenvolvimento de uma região, mas é uma condição absolutamente necessária.

Isto ocorre porque a presença de tecnologia, informação e mesmo outros componentes da infra-estrutura estão condicionados à sua presença.

É neste contexto que este trabalho procura estudar a disponibilização da energia elétrica, através de uma visão integrada que contemple sua inserção entre os diversos componentes da infra-estrutura e sua inter-relação com os aspectos do Desenvolvimento Sustentável.

\subsection{A Gestão Integrada de Recursos}

A forma proposta neste trabalho para a análise integrada da energia elétrica no contexto da infra-estrutura é a chamada Gestão Integrada de Recursos - GIR.

A GIR procura realizar uma análise ampla da disponibilização da infraestrutura e estabelecer condições para que tal disponibilização ocorra.

Para tanto avalia e orienta as atuações do Estado, do empresariado e da sociedade, procurando harmonizar interesses e garantir condições para que 
haja interesse do setor privado em disponibilizar os componentes da infraestrutura.

O Estado, no presente paradigma de desenvolvimento, deve atuar preferencialmente como ente regulador e, quando conveniente, através dos meios apropriados, como financiador.

Por Estado aqui entende-se o país, com leis e regulação que não estão condicionados ao governo da vez. O governo (curto prazo: mandatos) não deve ter muita influência no processo regulatório ou de financiamento, que devem ser providos por instituições relativamente independentes e com objetivos de longo prazo.

Através de mecanismos regulatórios, o Estado tem meios para incentivar a participação do setor privado na infra-estrutura, e mais do que isso, deve estabelecer critérios ambientais e sociais que estejam de acordo com a busca da sustentabilidade.

Estes mecanismos, muitas vezes, são de difícil aceitação pela população.

Ao empresariado, caberá a parte de investir e gerenciar a infra-estrutura, de forma a garantir a qualidade nos serviços prestados, a eficiência na operação e a acessibilidade por parte das mais carentes, dentro de critérios estabelecidos na regulação. Neste contexto, o investimento, em certos casos, poderá contar com a alavancagem do Estado como financiador através dos entes apropriados, como por exemplo o BNDES. 
Para a sociedade caberá, além de colher os benefícios da disponibilidade de infra-estrutura, participar ativamente do processo de planejamento.

A GIR busca a sinergia entre componentes da infra-estrutura (construtiva e operativa), procurando identificar os serviços mais rentáveis, os socialmente e ambientalmente mais necessários e a associação entre estes componentes e possíveis parceiros de forma a garantir o suprimento permanente destes serviços.

Resumidamente, a GIR deve proceder uma análise institucional, econômica, social e ambiental dos empreendimentos em infra-estrutura, como forma de disponibilizá-los sob a ótica do Desenvolvimento Sustentável. Ou seja, garantido a viabilidade econômica dos empreendimentos através do investimento privado, garantindo o acesso à infra-estrutura pela população (especialmente a mais carente) e preservando-se o meio ambiente.

\subsection{Roteiro do Trabalho}

Com o objetivo de abordar todos os aspectos importantes citados anteriormente, além de apresentar um estudo de caso, o trabalho seguiu o seguinte roteiro:

No capítulo 2 foram abordados aspectos da provisão de infra-estrutura e sua relação com o meio ambiente e o desenvolvimento sustentável. Também foi situada a importância da energia elétrica neste contexto. 
No capítulo 3 foi abordado o conceito de aceitabilidade de projetos de infra-estrutura e sua importância para a viabilização dos mesmos sob o enfoque da sustentabilidade.

No capítulo 4 foi apresentada uma proposta de conceituação e modelagem da Gestão Integrada de Recursos. Também foram apresentados exemplos de metodologias e métodos de análise pertinentes à metodologia apresentada.

No capítulo 5 foi proposto um estudo de caso, baseado em dados da região do Vale do Médio Paranapanema, propondo a implantação de uma Pequena Central Hidrelétrica e um projeto de irrigação para produção agrícola na região. Primeiramente foi analisada a abordagem tradicional, de dois investimentos isolados e, posteriormente, segundo a ótica da GIR. Foram comparados os aspectos econômico, social, ambiental, político e tecnológico, das duas abordagens.

Finalmente, no capítulo 6, apresentam-se as conclusões e considerações relativas ao trabalho. 


\section{INFRA-ESTRUTURA, MEIO AMBIENTE E DESENVOLVIMENTO SUSTENTÁVEL - A ENERGIA ELÉTRICA}

\subsection{Infra-Estrutura}

Por infra-estrutura entende-se o conjunto de estruturas construídas pelo homem que visam a alteração do meio ambiente de forma a proporcionar o desenvolvimento das atividades humanas. Através da disponibilização da infraestrutura objetivam-se (nem sempre se atingem) melhoras no campo da saúde e do bem estar social, através do desenvolvimento econômico e produtivo, com conseqüente redução da pobreza, analfabetismo, mortalidade infantil, etc. .

A realização de tais objetivos não é tarefa simples, pois a infra-estrutura tem uma componente sinérgica muito forte com o meio ambiente (podendo ser bem ou mal utilizada), além de sua provisão estar intimamente ligada à interesses políticos e econômicos, tornando seu desempenho dependente de fatores que estão muito além da questão técnica e da necessidade social.

Sua presença é necessária à implantação de atividades produtivas e ao desenvolvimento de uma região. Como será visto no decorrer deste trabalho, o desenvolvimento depende de outros fatores, mas está fortemente relacionado com a presença da infra-estrutura.

Existem diversos componentes da infra-estrutura que podem ser considerados no escopo de um planejamento com vistas ao desenvolvimento de determinada região, mas identificam-se como sendo os mais representativos: a Energia Elétrica, as Telecomunicações, o Transporte, 
Água e Saneamento Básico, e por fim o Tratamento do Lixo. Tais componentes são responsáveis por mais de $90 \%$ dos investimentos feitos no setor pelos países em desenvolvimento (Banco Mundial, 1994, [Ref. 1]).

Apresentam-se a seguir os diagramas da composição simplificada de cada um destes componentes.

\section{Energia Elétrica}

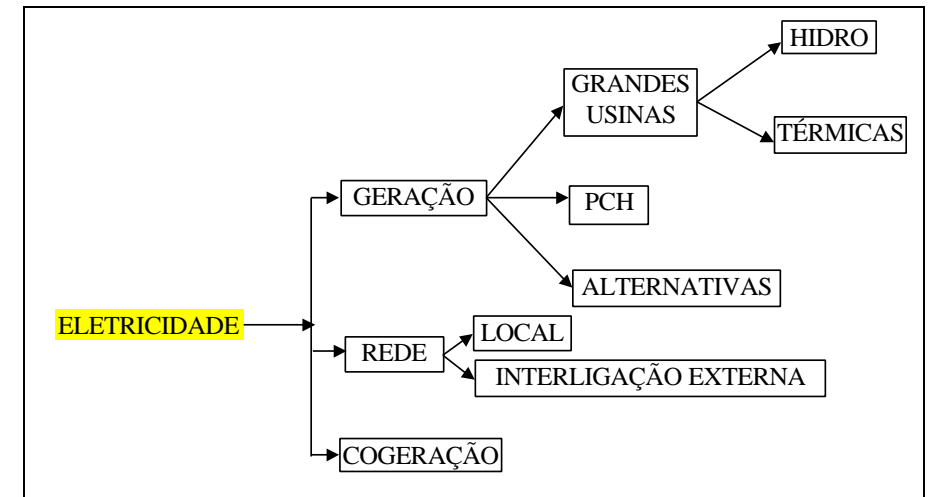

Figura 2.1 : Infra-estrutura para Energia Elétrica

\section{Água e Saneamento}

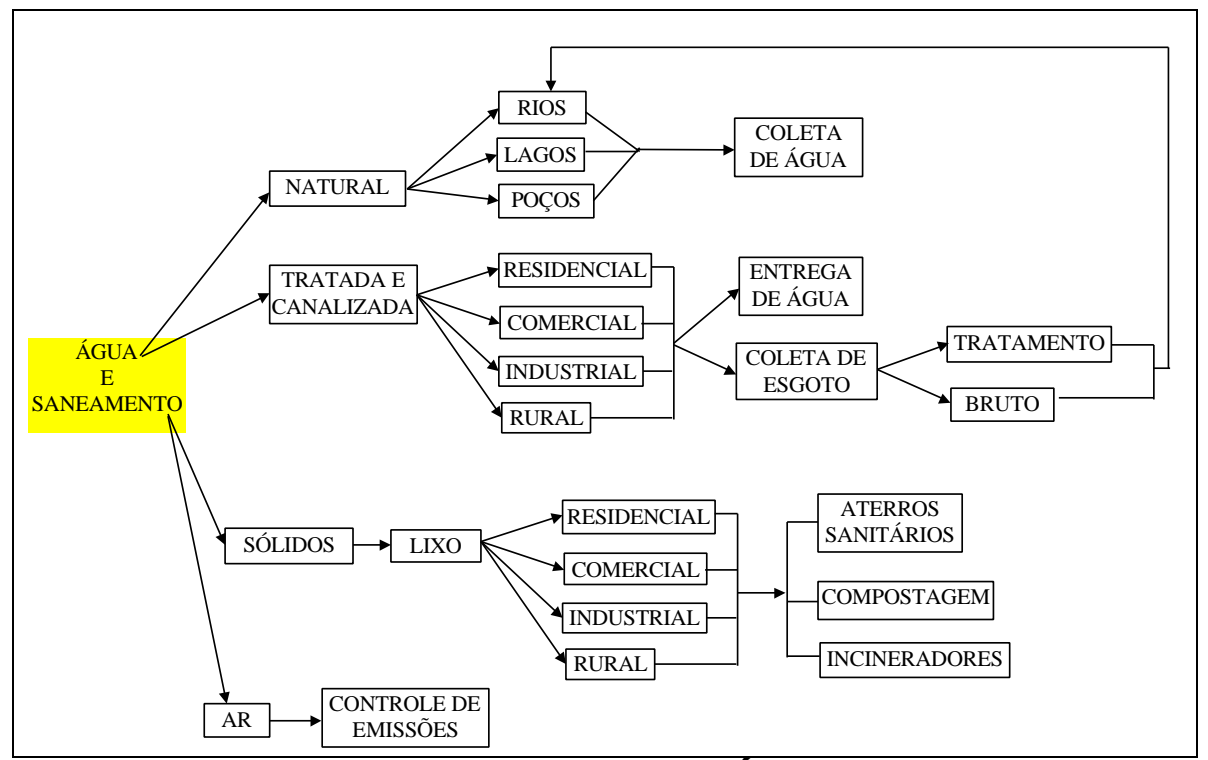

Figura 2.2 : Infra-estrutura para Água e Saneamento 
Transporte

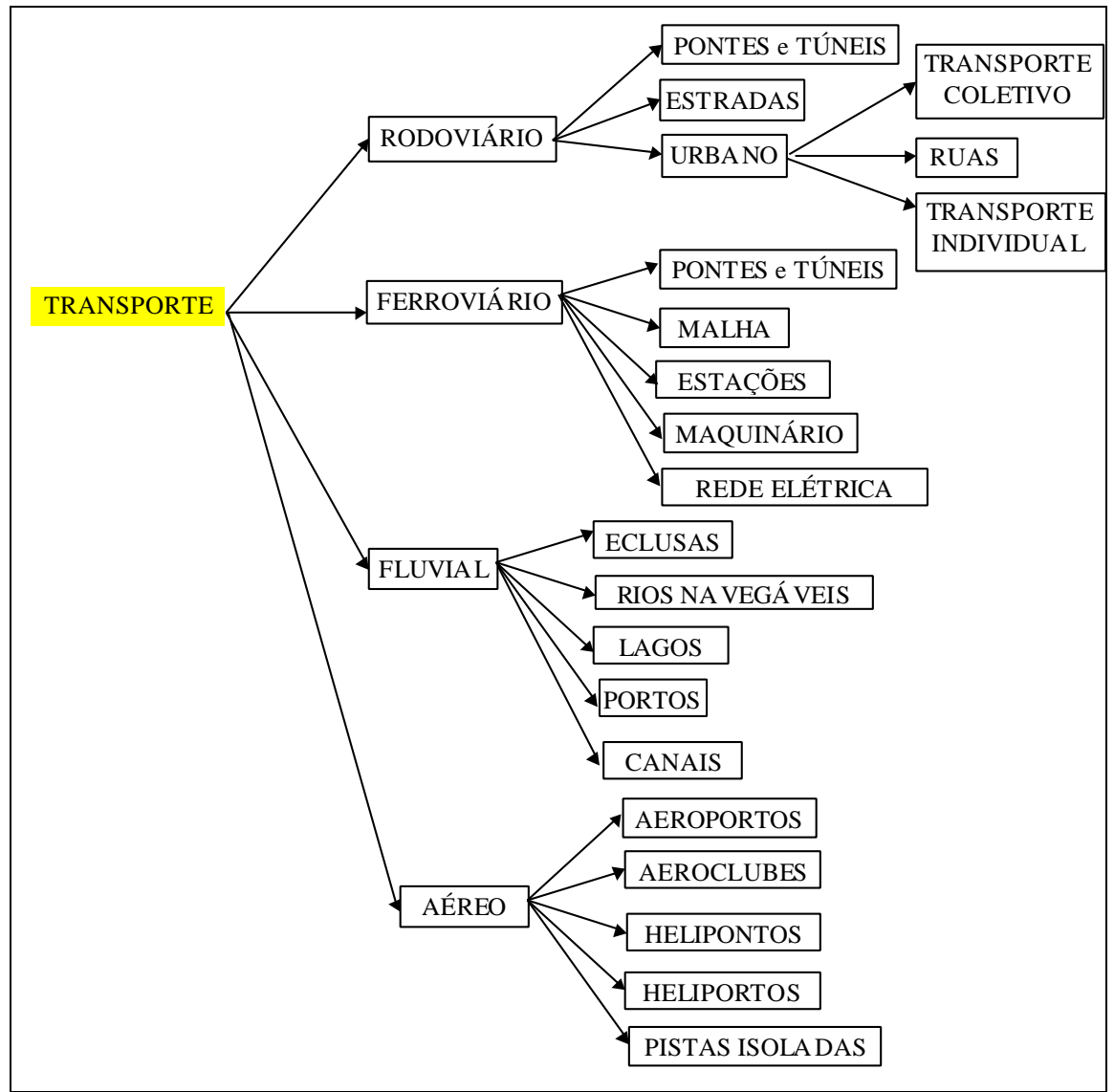

Figura 2.3 : Infra-estrutura para Transporte

\section{Lixo - Tratamento}

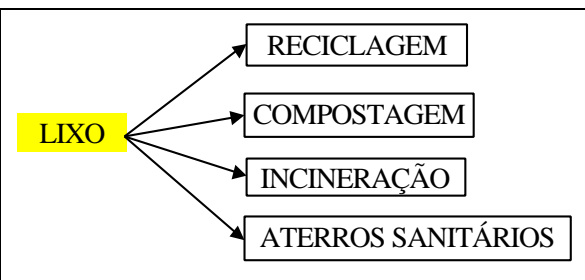

Figura 2.4 : Infra-estrutura para Tratamento do Lixo 
Telecomunicações

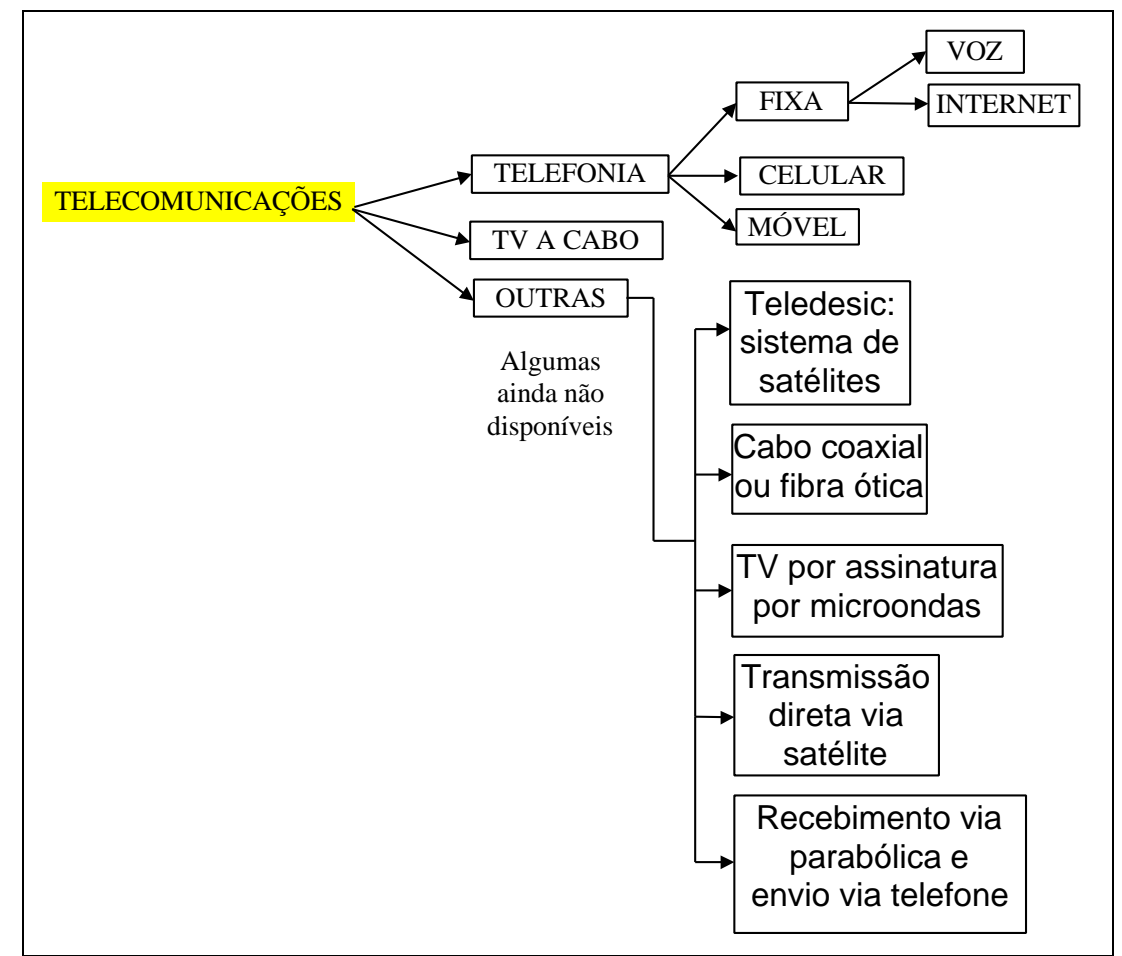

Figura 2.5 : Infra-estrutura para Telecomunicações

\subsection{Infra-estrutura e a Interacão com o Meio Ambiente}

Como dito anteriormente, a infra-estrutura tem como objetivo principal a melhora na qualidade de vida do homem, através da redução da pobreza, aumento do conforto, da produtividade, etc.. Isto é alcançado através do processo de intervenção do homem no meio ambiente, o que pode ser danoso ou até benéfico, dependendo da maneira como a implantação e operação da infra-estrutura sejam conduzidas.

Assim, deve-se buscar uma integração sustentável da infra-estrutura com o meio ambiente, caso contrário, os benefícios podem ser suplantados pelas conseqüências adversas da degradação ambiental. Por exemplo, um crescimento mal gerenciado no componente transporte pode aumentar a poluição atmosférica e diminuir os benefícios de uma política de saúde pública. 
A implantação de determinado componente da infra-estrutura pode ser consistente com a preservação ambiental e o desenvolvimento sustentável, desde que bem projetada e administrada. Mesmo assim, a interação entre as diversas partes da infra-estrutura e o meio ambiente é bastante complexa, dada as características muito particulares de cada uma.

A seguir são apresentadas algumas dessas interações, para cada um dos componentes da infra-estrutura considerados, não sendo o intuito deste trabalho o aprofundamento em cada item, o que por si só justificaria um trabalho a parte.

\subsection{1 Água e Saneamento}

O saneamento básico é um dos componentes mais importantes da infraestrutura, no que concerne ao meio ambiente, pois uma coleta de esgotos eficiente seguida de adequado tratamento do mesmo, pode colaborar para a sustentabilidade das grandes cidades, principalmente no que tange ao aumento da população e conseqüente aumento de efluentes. Ao contrário, somente a coleta sem o posterior tratamento, pode levar à contaminação de lençóis freáticos e à poluição de rios (acabando com importante reservatório de água para abastecimento, além da importante opção de lazer, pesca e irrigação associados). Além disso, pode contribuir para o aumento de enchentes e reduzir os benefícios em saúde associados aos investimento em água. Quando não há sequer a coleta, além dos anteriores, são gerados problemas gravíssimos de saúde pública.

$\mathrm{Na}$ área rural, o problema relativo ao saneamento é ainda mais sério. 
Um exemplo deste fato é a poluição na região oeste de Santa Catarina, decorrente da suinocultura, relatado pelo PNUD [Ref. 31]. Esta região concentra $80 \%$ do rebanho de suínos do estado, que é de 6,5 milhões de cabeças.

Muitas destas criações encontram-se próximas de cursos d'água, que acabam sendo contaminados pelo esterco dos suínos. Só para se ter uma idéia do potencial poluidor destas criações, o esterco produzido por elas é equivalente à produção de dejetos humanos de uma população de 30 milhões de habitantes (a região tem pouco mais de 1 milhão). Infelizmente, uma grande parte deste esterco (que pode ser aproveitado para agricultura, como fertilizante) tem ido para os rios.

Este exemplo mostra claramente que os impactos decorrentes de uma estrutura de saneamento inadequada no meio rural podem ser superiores àqueles produzidos pelos grandes centros urbanos.

Outro aspecto relativo à água no meio rural é a sua utilização para irrigação.

O mau uso deste recurso (que pode até triplicar uma dada produção) pode acarretar a salinização do solo, contribuindo para a destruição do mesmo, pois a terra salinizada dificulta a germinação de sementes e o desenvolvimento das plantas, podendo levá-las à morte (PNUD, 1999, [Ref. 31]).

"Além disso, a água aplicada em excesso retorna para córregos, rios ou para os lençóis freáticos, carregando sedimentos e resíduos de agroquímicos (Salasier, 1997). Também os sedimentos provenientes da erosão contém nitrogênio e fósforo que podem desencadear processos de eutrofização, isto é, 
um aumento de nutrientes que possibilita o rápido desenvolvimento de vegetais aquáticos, principalmente as algas, que elevam o consumo de oxigênio e impedem a sobrevivência de outros organismos como peixes e crustáceos (Brady, 1983). Os animais aquáticos também são afetados pelo aumento da turgidez da água provocada pelo aumento das partículas em suspensão. Outro problema é que os sedimentos podem conter resíduos de metais pesados presentes em fertilizantes e corretivos.

Podem ocorrer também o assoreamento e a contaminação dos córregos e rios pela erosividade dos solos. Fertilizantes e agrotóxicos, utilizados em grandes quantidades, são acrescidos na água, que contamina os depósitos e lençóis subterrâneos, comprometendo os mananciais a jusante (Reis e Rassini, 1976, et. al.,)" (PNUD, 1999 [Ref. 31]).

Além destes aspectos, o uso indiscriminado da irrigação reduz a disponibilidade de água para o uso da população, das atividades industriais e para a produção de energia elétrica.

A questão dos resíduos sólidos será apresentada no item Lixo.

\subsubsection{Energia Elétrica}

Dos diferentes componentes da infra-estrutura aqui considerados, a energia elétrica é a que talvez apresente a maior gama de impactos ao meio ambiente.

Considerando-se as diferentes formas de geração, vê-se que os impactos ao meio ambiente são ainda mais diversificados, de acordo com as 
particularidades de cada uma. Um detalhamento de cada caso foge ao escopo proposto pelo presente trabalho.

As principais formas de geração são a hidrelétrica, termelétrica (incluindo-se as nucleares) e as fontes alternativas. Seus principais impactos são descritos a seguir.

\subsubsection{Hidrelétrica}

Embora seja renovável e não apresente emissões aéreas, apresenta diversos impactos significativos sobre o meio aquático e biótico, por represar águas correntes, o que provoca sedimentação, com conseqüente assoreamento e alteração da qualidade dessas águas.

Além disso, imobiliza grandes quantidades de terras, muitas vezes produtivas, representando perdas com produção agrícola, ou então a destruição de áreas com vegetação e fauna nativas, e que neste caso pode passar a apresentar emissões de gases como efeito da decomposição desta matéria orgânica.

Ocorrem também problemas relativos à estabilidade de encostas, aspectos paisagísticos, perda de recursos minerais e de sítios arqueológicos inundados, além de possível elevação e contaminação de lençóis freáticos.

Além destes, diversos outros problemas sócio-econômicos estão associados à construção de barragens, tais como: proliferação de doenças transmissíveis pelo meio aquático, diminuição do nível de emprego associados à perda de terras, aumento da demanda por serviços sociais durante a 
construção da barragem, inundação de comunidades e áreas indígenas, reservas florestais etc..

Muitas vezes, tais problemas também podem superar os benefícios associados à sua implantação, fato este que deve ser levado em consideração em um planejamento que visa o desenvolvimento sustentável de uma região.

\subsubsection{Termelétrica}

As usinas termelétricas variam muito quanto aos seus impactos ao meio ambiente, de acordo com o combustível que utilizam, mas seu impacto comum e mais significativo é a emissão de efluentes aéreos, em especial os gases estufa, ressaltando-se que a geração de energia elétrica é a segunda maior causadora dos "gases-estufa" $\left(\mathrm{CO}_{2}\right.$, principalmente), e, portanto, do Aquecimento Global (Global Warming), perdendo apenas para o setor de transportes (Reis, 1999, [Ref. 2]).

Os principais efluentes são:

\section{Dióxido de Carbono $\left(\mathrm{CO}_{2}\right)$}

Quando em excesso na atmosfera, o $\mathrm{CO}_{2}$ é o principal causador do efeito estufa, que pode implicar no aquecimento global do planeta. Como é dissociável em água, a sua presença na atmosfera contribui para formação de chuva ácida, como o ácido carbônico, além de seu excesso também causar dificuldades respiratórias, principalmente em idosos e recém nascidos.

\section{Óxidos de Enxofre $\left(\mathrm{SO}_{\mathrm{x}}\right)$}


O $\mathrm{SO}_{\mathrm{x}}$ é responsável por problemas respiratórios na população que vive em torno de usinas que não controlam suas emissões. Dependendo de sua concentração na atmosfera pode possibilitar o surgimento de chuva ácida e outros efeitos ambientais a consideráveis distâncias do local da emanação.

\section{Material Particulado (MP)}

Uma parte das cinzas formadas durante o processo de combustão ou presentes no combustível é arrastada pelo fluxo de gases para a chaminé, sendo lançada para a atmosfera. O MP afeta o meio ambiente pelos efeitos decorrentes de sua deposição nos bens imóveis e suas benfeitorias, no sistema respiratório de pessoas e animais, em plantas e vegetais, na ação sobre a visibilidade atmosférica e instalações elétricas, etc.

\section{Óxidos de Nitrogênio}

$\mathrm{O} \mathrm{NO}_{x}$, em concentrações altas, provoca $\mathrm{o}$ agravamento de enfermidades pulmonares, cardiovasculares e renais, bem como a redução no crescimento das plantas e a queda prematura das folhas. $\mathrm{O} \mathrm{NO}$ em particular, é substância chave na cadeia fotoquímica para a formação do 'smog'.

\section{Monóxido de Carbono e Hidrocarbonetos}

O maior perigo dos hidrocarbonetos decorre da sua reação fotoquímica com os óxidos de nitrogênio, gerando compostos oxidantes. O monóxido de carbono é um item importante para o controle da eficiência de operação da caldeira, estando dessa forma sob constante monitoramento.

Além dos efluentes aéreos há ainda os efluentes líquidos que podem afetar física e/ou quimicamente o solo e as águas superficiais e subterrâneas. 
São provenientes do Sistema de Refrigeração, Sistema de Tratamento de Água, Purga das Caldeiras, Líquidos para Limpeza de Equipamentos. Além de outros efluentes, tais como: Efluentes sanitários, de drenagem e Cinzas.

\section{Nucleares}

A centrais térmicas nucleares apresentam como principal risco ao meio ambiente a disposição dos resíduos radioativos provenientes de sua operação, chamados de "lixo atômico". A periculosidade (ao meio ambiente e ao ser humano), destes resíduos se extende por centenas de anos, o que requer cuidados especiais ao tratamento e disposição deste lixo, que é armazenado em tambores especiais, que são concretados e depois dispostos na natureza, enterrando-os em minas abandonadas, jogando-os no fundo do mar etc..

Além disso, há o fator relativo ao risco de vazamentos, provenientes do lixo atômico, de falhas no reator ou na operação das usinas, que podem causar acidentes como o de Chernobil, que contaminou milhares de pessoas. Este risco implica na rejeição pública à implantação de usinas nucleares, e já existem casos de projetos abandonados devido à pressões da sociedade.

\subsubsection{Fontes Alternativas}

As fontes alternativas tais como: solar fotovoltáica, eólica, geotérmica, das marés, etc. apresentam impactos ambientais significativamente menores que as anteriores e devem ser consideradas no planejamento de uma região como forma sustentável de disponibilização de energia elétrica, sendo muitas vezes a solução para eletrificação de áreas rurais ou comunidades isoladas. 


\subsubsection{Lixo}

Os resíduos sólidos representam sérios riscos à saúde. Um incorreto tratamento do lixo residencial pode, por exemplo, trazer o aparecimento de mosquitos transmissores de doenças, podendo ainda contaminar de maneira significativa o solo e reservatórios naturais de água.

O lixo industrial tóxico também representa uma séria ameaça ao meio ambiente, pois seu incorreto armazenamento pode implicar em grave contaminação do solo e água, representando riscos à população e animais.

Quando o lixo é incinerado, uma atenção especial deve ser dada aos efluentes aéreos, que devem ser devidamente filtrados e tratados antes de sua liberação na atmosfera.

Uma política correta de coleta e tratamento do lixo pode evitar tais problemas, sendo, portanto, uma forma de garantir a absorção do crescimento do lixo sem danos significativos ao meio ambiente.

\subsubsection{Transporte}

Os veículos com motores à combustão, baseados nos derivados do petróleo, são os maiores responsáveis por efluentes aéreos tóxicos nas grandes cidades e por $95 \%$ da contaminação aérea por chumbo. Sua contribuição para o efeito estufa é significativa, além da emissão do monóxido de carbono, que em grandes concentrações traz graves problemas respiratórios, principalmente em idosos e crianças. 
Tais problemas acarretam elevados custos sociais, principalmente relacionados com a saúde pública. Estima-se que em Bangkok, uma cidade com 6 milhões de habitantes, uma redução de $20 \%$ na poluição aérea, produziria benefícios anuais entre US\$100 e US\$ 400 per capita (Banco Mundial, 1994, [Ref. 1]).

Dessa maneira, ao pensar-se no desenvolvimento da infra-estrutura de transportes, deve-se ter em mente uma política racional de controle de congestionamentos, de transporte coletivo de massa, além de um plano de incentivo ao uso de veículos mais eficientes e com melhor controle de emissões, bem como o incentivo ao uso de combustíveis limpos.

\subsubsection{Telecomunicações}

As telecomunicações são as que apresentam os menores impactos ambientais diretos, que são, inclusive, de difícil determinação. Sua estrutura é, geralmente, menor e menos impactante que as demais, sendo, por exemplo a utilização de postes ou a construção de antenas para transmissão.

Sua atuação sobre o meio ambiente pode ainda ser bastante positiva, se for utilizada para garantir o acesso à informação por parte da população, o que pode ser associado à um trabalho de conscientização das responsabilidades ambientais do indivíduo, sendo este um eficiente meio de conservação ambiental. 


\subsection{Infra-estrutura e o Desenvolvimento Sustentável}

"O atual contexto mundial é caracterizado por drásticas mudanças nos paradigmas que orientam a organização da sociedade humana. Estas mudanças vêm-se impondo já há algumas décadas. Problemas como o aquecimento global, a ocorrência de grandes desastres ecológicos, a existência de grandes populações vivendo em condições de profunda pobreza e a má distribuição da riqueza natural e humana demonstraram os aspectos ecologicamente predatórios, socialmente perversos e politicamente injustos do paradigma de desenvolvimento que vinha sendo adotado particularmente desde o período pós-guerra.

Além disso, tem crescido a conscientização sobre as significantes interferências que sistemas humanos impõem sobre sistemas naturais, sobre o desequilíbrio ambiental que estas interferências podem causar, e os impactos irreversíveis que tal desequilíbrio pode ter sobre o meio ambiente.

Essas constatações motivaram a busca de um novo paradigma capaz de não só contribuir para superar os atuais problemas mas também de garantir a própria vida através da proteção e manutenção dos sistemas naturais que a tornam possível. Dessa forma nasceu o paradigma do desenvolvimento sustentável. Esse "novo paradigma" implica na necessidade de mudanças nos atuais sistemas de produção, organização da sociedade humana e utilização de recursos naturais essenciais à vida humana e a outros seres vivos.

A noção de desenvolvimento sustentável está além da simples consideração da questão ambiental. Os problemas ambientais estão diretamente relacionados com os problemas da pobreza, como o atendimento 
às necessidades básicas de alimentação, saúde e moradia. É necessário rever os sistemas de produção quanto à escolha, gerenciamento e utilização dos recursos naturais, bem como quanto ao processo de inovação tecnológica. A solução para as questões ambientais tem que ser encontrada dentro de um contexto amplo onde questões sociais, econômicas e políticas precisam também ser revistas.

Companhias internacionais não mais ignoram o fato de que padrões de sustentabilidade irão afetar mais e mais os padrões de consumo da sociedade e as formas de produção que dominarão o próximo século, sendo portanto condicionantes significativos de competitividade", (Reis, 1999, [Ref.3]).

A disponibilidade de infra-estrutura é uma das condições básicas para a redução da pobreza e a promoção do desenvolvimento. Quantificar os impactos de sua presença sobre a população ou sua influência sobre o PIB de uma região não é tarefa fácil, sendo motivo até de controvérsias. Mas sabe-se que seus impactos sobre a população e a produção são, via de regra, positivos.

Sobre o meio ambiente, seus impactos dependem da forma como é conduzida a administração de seus componentes, como será discutido posteriormente.

Os países em desenvolvimento têm investido cerca de US\$200 bilhões por ano em infra-estrutura. Não obstante a quantia e o conseqüente aumento na disponibilidade de infra-estrutura, hoje, aproximadamente 1 bilhão de pessoas estão sem acesso à água limpa, e 2 bilhões sem acesso à eletricidade. Além disso, muito do que já foi feito apresenta-se com estruturas ineficientes ou inadequadas, representando grande soma de capital 
desperdiçado. Só nos setores de água, energia e ferrovias, estima-se que a perda anual devida à ineficiência é da ordem de US\$ 55 bilhões, somente nos países em desenvolvimento (Banco Mundial, 1994, [Ref. 1]).

A seguir tem-se a Tabela 2.1 que mostra a cobertura de infra-estrutura nos países.

\section{Tabela 2.1: Cobertura de Infra-Estrutura nos Países}

\begin{tabular}{|c|c|c|c|c|c|}
\hline Indicador & $\begin{array}{c}\text { Economias de } \\
\text { baixo PIB per } \\
\text { capita }\end{array}$ & $\begin{array}{c}\text { Economias em } \\
\text { transição } \\
\text { (em Desenvolv.) }\end{array}$ & $\begin{array}{c}\text { economias de } \\
\text { médio PIB per } \\
\text { capita }\end{array}$ & $\begin{array}{l}\text { Economias de } \\
\text { alto } \\
\text { crescimento }\end{array}$ & OECD \\
\hline \multicolumn{6}{|l|}{ Cobertura de infra-estrutura } \\
\hline Linhas por mil pessoas & 3 & 95 & 73 & 122 & 475 \\
\hline $\begin{array}{l}\text { Casas /c acesso à água } \\
\text { limpa (\%) }\end{array}$ & 47 & 95 & 76 & 86 & 99 \\
\hline Casas c/ eletricidade (\%) & 21 & 85 & 62 & 61 & 98 \\
\hline \multicolumn{6}{|c|}{ Desempenho das infra-estruturas } \\
\hline Perdas de energia & 22 & 14 & 17 & 13 & 7 \\
\hline $\begin{array}{l}\text { Vias pavimentadas em } \\
\text { condições ruins (\%) }\end{array}$ & 59 & 50 & 63 & 46 & 15 \\
\hline $\begin{array}{l}\text { Vias pavimentadas em } \\
\text { boas condições }(\%)\end{array}$ & 35 & 28 & 37 & 39 & 13 \\
\hline $\begin{array}{l}\text { Locomotivas Diesel fora de } \\
\text { uso (\%) }\end{array}$ & 55 & 27 & 36 & 26 & 16 \\
\hline Sem água (\%) & 35 & 28 & 37 & 39 & 13 \\
\hline
\end{tabular}

Fonte: World Development Report 1994, World Bank.

A seguir, na Tabela 2.2 tem-se alguns desses indicadores relativos ao Brasil, segundo dados do IBGE [Ref. 18].

Tabela 2.2: Domicílios por Condição de Saneamento e Luz Elétrica - 1996

\begin{tabular}{|c|c|c|c|c|c|}
\hline \multirow{2}{*}{} & \multirow{5}{*}{ Água } & \multicolumn{2}{|c|}{ Percentual (\%) } & \multirow{2}{*}{$\begin{array}{c}\text { Lixo } \\
\text { Coletado }\end{array}$} & $\begin{array}{c}\text { Luz } \\
\text { Elétrica }\end{array}$ \\
\cline { 2 - 4 } & & Rede Coletora & Fossa Séptica & Colo & 92,9 \\
\hline Brasil & 74,2 & 40,3 & 23,3 & 87,4 & 96,8 \\
\hline $\begin{array}{c}\text { Região Norte } \\
\text { Urbana* }\end{array}$ & 59,7 & 8,9 & 39,7 & 64,7 & 81,7 \\
\hline Região Nordeste & 56,2 & 15,3 & 22,4 & 72,9 & 97,8 \\
\hline Região Sudeste & 86,5 & 69,0 & 13,9 & 92,9 & 96,8 \\
\hline Região Sul & 77,0 & 14,0 & 52,6 & 95,6 & 93,2 \\
\hline $\begin{array}{c}\text { Região Centro } \\
\text { Oeste }\end{array}$ & 65,5 & 15,0 & 11,3 & 89,2 & \\
\hline
\end{tabular}

Fonte: Pesquisa Nacional por Amostra de Domicílios: síntese de indicadores 1996. Rio de Janeiro: IBGE, 1997. P.9799 (Tabela 6.12). * Exclusive a população da área rural de Rondônia, Acre, Amazonas , Pará e Amapá 
Estes dados são apenas ilustrativos, uma vez que, dadas as proporções do território brasileiro, existem diferenças sociais muito grandes entre as diversas regiões, que ficam, na maioria das vezes, camufladas em dados médios como estes.

A falta de infra-estrutura básica impede o desenvolvimento das atividades produtivas, desde as mais básicas, como a agricultura (irrigação), até as mais sofisticadas, como a indústria (energia elétrica, telecomunicações, etc.), além de representar riscos à saúde da população, falta de educação, emprego, etc..

Ao contrário, a sua disponibilidade pode significar, além do desenvolvimento de tais atividades, o acesso à novos mercados, o que é de extrema importância para os países em desenvolvimento.

No caso de países desenvolvidos, além do transporte, a presença das telecomunicações, da energia elétrica e da água são fatores determinantes para o sucesso de suas empresas no mercado global, que possui elevados índices de exigências.

Dados do Banco Mundial comprovam que há uma forte ligação entre a disponibilidade de infra-estrutura e o PIB per capita, sem no entanto estabelecer uma relação de causa e efeito. Tais dados permitem verificar-se que a cada $1 \%$ de incremento na disponibilidade de infra-estrutura está associado um crescimento da mesma ordem no PIB dos países, [Ref. 1].

Ainda segundo o Banco Mundial, [Ref. 1], a maior parte da pobreza encontra-se na zona rural, cujo aumento da produtividade e nível de emprego 
está intimamente relacionado com a disponibilidade de infra-estrutura. Neste caso pode-se citar o exemplo de Bangladesh, onde vilas rurais com maior acesso ao transporte apresentam produções agrícolas significativamente maiores que as menos desenvolvidas, além de maiores níveis de salários, empregos e saúde.

Ainda na área rural, a presença de água potável de qualidade pode possibilitar a produção de alimentos processados, de maior valor agregado, que garantem maior lucro e geram mais empregos do que a venda de produtos agrícolas in natura.

Ainda do ponto de vista da sustentabilidade, vale ressaltar que o investimento em infra-estrutura, principalmente em épocas de recessão, é uma eficiente forma de geração de empregos e de estímulos à novos negócios.

O investimento em infra-estrutura não implica necessariamente em desenvolvimento, que depende de diversos outros fatores para acontecer, mas garante, como já dito, as condições básicas para sua ocorrência, desde que responda efetiva e eficientemente à demanda pelos serviços associados aos sub-setores da infra-estrutura.

Como será visto adiante, a sustentabilidade da implantação da infraestrutura estará associada ao retorno do capital investido, sendo que esta é uma das preocupações deste trabalho. Posteriormente serão discutidos os impactos e benefícios trazidos pela implantação de determinados componentes da infra-estrutura em uma região. 


\subsubsection{Considerações Quanto aos Investimentos em Infra-Estrutura}

Segundo dados do Banco Mundial, os países em desenvolvimento têm gasto por volta de US\$200 bilhões por ano em infra-estrutura, sendo que a participação dos governos raramente é menor que 30\%, sendo, na maior parte das vezes, em torno de $70 \%$ [Ref. 1].

Seja por investimentos anteriores mal alocados ou por ajustes orçamentários indispensáveis, os governos destes países têm tido a sua capacidade de investimento em infra-estrutura bastante reduzida.

Paralelamente, a demanda por tais serviços tem crescido rapidamente, não só pelo aumento da produção, mas também pela necessidade de modernização para competição no mercado globalizado.

Tal situação aponta para um cenário não sustentável de crescimento, com demanda crescente e investimentos decrescentes em infra-estrutura, apontando para a necessidade de novas abordagens para garantir tal tipo de investimento.

Nesta linha, a privatização de serviços e a busca da parceria com o setor privado têm sido apontados como caminhos para garantir os investimentos em infra-estrutura sem prejuízo para o crescimento [Ref. 1].

Diversas empresas especializadas em determinados sub setores da infra-estrutura estão buscando a ampliação estratégica de seus mercados nos países em desenvolvimento, que apresentam grande potencial de crescimento, ao contrário dos países desenvolvidos, que apresentam mercados estabilizados. Em 1994, a participação do setor privado em infra-estrutura nos 
países em desenvolvimento era da ordem de $7 \%$ e espera-se que este percentual dobre até o ano 2000. Ressalta-se que esta participação é ainda maior na América Latina, e concentra-se especialmente nos setores de $\underline{\text { Telecomunicações e Energia Elétrica. }}$

Mesmo assim, os governos ainda terão um papel importante no desenvolvimento da infra-estrutura, principalmente em áreas de maior carência social, que muitas vezes não apresentam grandes atrativos aos investidores privados.

As formas institucionais de participação e investimento em infra-estrutura variam bastante, mas podem-se identificar as principais como sendo:

> Construção-Operação-Transferência: onde o investidor privado (ou consórcio) financia, constrói e opera determinado empreendimento e, depois de um período determinado, o transfere para o setor público.

> Construção e Operação Privadas: onde a diferença da anterior consiste em que não há posterior transferência para o setor público, sendo este mais atrativo ao setor privado, quando os riscos comerciais e políticos são baixos.

> Concessão: onde por um período estipulado, o setor privado opera e mantém um determinado serviço, sob concessão do setor público.

> Construção e Operação Públicas: que, como o próprio nome já diz, não há participação do setor privado.

Além disso, pode-se investir para: a) implementação de uma infraestrutura nova; b) ampliação de uma já implantada; c) ou simplesmente revitalização de uma estrutura deteriorada; 


\subsubsection{Considerações sobre a Inserção da Infra-Estrutura em um Ambiente de Mercado}

Historicamente, os investimentos em infra-estrutura têm alcançado níveis de retorno (tanto do capital quanto do desenvolvimento) abaixo do esperado, conforme resultados do Banco Mundial [ref. 1].

Assim sendo, para que se obtenha o retorno esperado de um investimento em infra-estrutura, alguns cuidados importantes devem ser tomados. Abaixo seguem alguns dos fatores determinantes da falta de retorno dos investimentos em infra-estrutura realizados pelo Banco Mundial:

A manutenção inadequada da infra-estrutura implantada, o que leva à perdas elevadas de capital e recursos, pois enquanto se investe em novas estruturas, as antigas vão se deteriorando até o ponto em que necessitam ser reconstruídas;

- Operação inadequada, que envolve desperdícios na distribuição e/ou transmissão do bem (p. ex. água encanada), excesso de pessoal, etc. ;

Investimentos mal alocados e problemas com incentivos fiscais, sejam em componentes da infra-estrutura inapropriados ou em padrões inadequados à demanda, onde o usuário tem dificuldade para arcar com os custos do serviço prestado. Também em estruturas prematuras para uma determinada região, que operam abaixo de sua capacidade, gerando pouco retorno do capital investido. Na questão dos incentivos fiscais, políticas inadequadas de incentivos podem levar à distorções que afetam negativamente a macro 
economia da região e impedem uma operação sustentável do empreendimento;

Desperdício e ineficiência na infra-estrutura implantada geralmente superam os benefícios alcançados. Uma infra-estrutura mal administrada representa uma das maiores fontes de degradação ambiental.

Tais problemas são alguns dos motivos para os desempenhos sofríveis de alguns planos de desenvolvimento implantados no passado, e mostram-se como desafios a serem superados pelos planos futuros.

A experiência do Banco Mundial [Ref. 1] tem mostrado que, ao contrário dos anteriores, alguns fatores são determinantes para o sucesso do investimento em infra-estrutura:

$>$ Deve ser administrada como negócio, ou seja, deve ter uma orientação comercial;

> Quando possível, deve ser introduzida a competição, cabendo a participação do governo como regulador, sempre que necessário;

> Usuários e acionistas devem participar efetivamente do processo de implantação;

$>$ O setor privado deve participar do processo, sabendo-se que os governos hoje, não mais exercem o papel de únicos provedores de infra-estrutura;

D Deve-se garantir o acesso dos mais pobres aos serviços de infra-estrutura;

$>$ Deve-se, em todos os aspectos, considerar a interação com o meio ambiente. 
D Deve-se dar grande atenção às novas tecnologias, que estão possibilitando mudanças no modo como os componentes da infra-estrutura são disponibilizados, apresentando novas oportunidades de negócios e melhorando o planejamento dos investimentos, bem como tornando tais componentes mais eficientes, robustos e flexíveis.

D Deve-se estar atento à novas formas de parceria e investimentos para prover a infra-estrutura;

Deve-se buscar disponibilizar a quantidade e qualidade adequadas da infraestrutura para possibilitarem a competitividade dos produto locais.

O sucesso da implementação de determinados componentes da infraestrutura depende do local, do período e do balanço entre suprimento e demanda. Os mercados com demanda reprimida em determinados serviços são os que, historicamente, têm apresentado os maiores índices de retorno dos investimentos [Ref. 1].

No caso do Brasil, existem inúmeras regiões com déficit de infraestrutura e grandes potenciais de desenvolvimento, representando assim boas oportunidades de investimentos e novos negócios.

Como foi dito, para se garantir a sustentabilidade dos empreendimentos, deve-se buscar a parceria do setor privado, mas sabe-se que a participação do governo será ainda muito importante, principalmente na provisão de infraestrutura à regiões muito pobres e que não apresentem condições de garantir retorno do capital investido. Neste sentido, a parceria e participação do setor privado é ainda mais relevante, pois poupa os governos de investirem em 
determinadas áreas, podendo se concentrarem em áreas cujo maior retorno é o social, através de mecanismos mais adequados, como a regulação.

\subsection{A Energia Elétrica no Contexto Global da Infra-Estrutura}

"Na organização mundial atual, a energia pode ser considerada como um bem básico para a integração do ser humano ao desenvolvimento. Isso porque a energia proporciona oportunidades e maior variedade de alternativas tanto para a comunidade como para o indivíduo. Sem uma fonte de energia de custo aceitável e de credibilidade garantida, a economia de uma região não pode se desenvolver plenamente. Também o indivíduo e a comunidade não podem ter acesso adequado à diversos serviços essenciais ao aumento da qualidade de vida como a educação, saneamento e saúde", (Reis, 1999, [Ref.3].

No contexto da energia, a elétrica tem papel preponderante, participando com $40 \%$ da matriz energética mundial, com tendência de crescimento. Tal crescimento tem razão de ser na medida em que as atividades industriais, comerciais e residenciais estão cada vez mais dependentes deste tipo de energia. Tal fato está calcado na elevação dos padrões de qualidade exigidos nos produtos e serviços ofertados, sem o cumprimento dos quais a indústria e o comércio fatalmente perderão espaço no mercado globalizado. A energia elétrica representa um papel preponderante no alcance de tais padrões, uma vez que os mesmos estão ligados à processos produtivos automatizados, à tecnologia da informação, aos computadores e, obviamente, à força motriz, 
elementos estes inconcebíveis sem a presença de energia elétrica de boa qualidade.

Mesmo em regiões com pouco desenvolvimento, a energia elétrica se mostra necessária para a transição da produção primária para produtos manufaturados de maior valor agregado, que é o caminho natural nesta etapa do desenvolvimento.

No tocante ao setor residencial, a medida em que o nível de desenvolvimento da região aumenta, itens como luz elétrica, refrigeração, televisão, chuveiro elétrico, passam a fazer parte efetivamente da vida das pessoas, e, em níveis posteriores, a energia elétrica proporciona conforto e acesso à informação, p ex. computador pessoal.

Neste contexto, a energia elétrica é um componente que vai além do conceito de provisão de condições básicas de infra-estrutura, ela é necessária como forma de garantir crescimento sustentado da produção nos seus mais diversos níveis de desenvolvimento.

Embora tal assertiva seja válida também para as telecomunicações, ressalta-se que a presença da energia elétrica deve ocorrer em uma etapa anterior a esta, por ser condição necessária ao desenvolvimento das telecomunicações.

O mesmo vale para a questão da água e saneamento, onde a energia elétrica é necessária, por exemplo, para o bombeamento de água.

A Energia Elétrica e as Telecomunicações, conforme será visto adiante, são os componentes da infra-estrutura que mais interessam ao setor privado, devido à viabilidade econômica e retorno do capital investido que apresentam, 
além de que, o setor privado já possui o domínio da tecnologia necessária para garantir a excelência nos serviços prestados. Assim, pode haver vantagens na associação destas como os outros componentes, cujo retorno maior é do ponto de vista social. Tal assunto será melhor desenvolvido na abordagem da Gestão Integrada de Recursos, em capítulo específico.

Desse modo, a energia elétrica assume um papel estrutural e estratégico no contexto da infra-estrutura com vistas ao Desenvolvimento Sustentável. 


\section{SUSTENTABILIDADE E ACEITABILIDADE - A VIABILIZAÇÃO DE}

\section{PROJETOS}

\subsection{Introducão}

A provisão de infra-estrutura, dentro do conceito de sustentabilidade, deve levar em consideração o balanço dos seguintes aspectos [Ref. 16]:

1 - Provisão das necessidades, que podem ser:

Absolutas: mínimo necessário de comida, água, teto e investimentos;

Necessidades pessoais: relacionadas à vida moderna;

Necessidade nacionais: relacionadas à necessidade que o país tem de ser competitivo e aumentar seu padrão de vida. Por exemplo transporte, educação.

Na provisão das necessidades deve-se considerar a problemática da acessibilidade, onde as camadas mais pobres da sociedade devem ter condição de usufruírem dos bens e serviços providos pela infraestrutura. Este conceito é fundamental na busca da sustentabilidade, sendo um de seus componentes, inclusive por ser decisivo para a preservação do meio ambiente.

2 - Provisão de recursos financeiros.

3 - Preservação do meio ambiente.

4 - Aceitabilidade. 
Embora haja um consenso geral de que se deve buscar a sustentabilidade, há um desafio ainda maior relacionado a esta busca, que é torná-la "aceitável".

A busca da sustentabilidade implica em mudança de atitude, comportamento, padrão de vida, investimento, regulação, punições, restrições e incentivos que, muitas vezes, tornam-se inaplicáveis. Isto porque há parcelas da sociedade que se opõem veementemente à algumas destas medidas, inviabilizando-as.

Dessa forma, enquanto a sustentabilidade atua no sentido de harmonizar os aspectos sociais, econômicos e ambientais no âmbito geral da existência humana, a aceitabilidade advém do conflito destes aspectos, face aos interesses particulares de cada segmento (ou, no limite: de cada indivíduo) da sociedade.

Como exemplo, considera-se que o uso do transporte individual, em detrimento do coletivo, é o caminho oposto ao da sustentabilidade. Dessa maneira, quando se busca a sustentabilidade, deve-se priorizar o transporte coletivo, impondo, se necessário, restrições ao uso de automóveis.

No entanto, não é difícil imaginar as implicações políticas e sociais de uma medida mais severa neste sentido. Com certeza, os proprietários de automóveis irão se opor à tais medidas e é bem provável que consigam anulálas.

Este é um exemplo de medida sustentável mas não aceitável, o que torna uma medida de sustentabilidade inviável, ver figura 3.1 . 


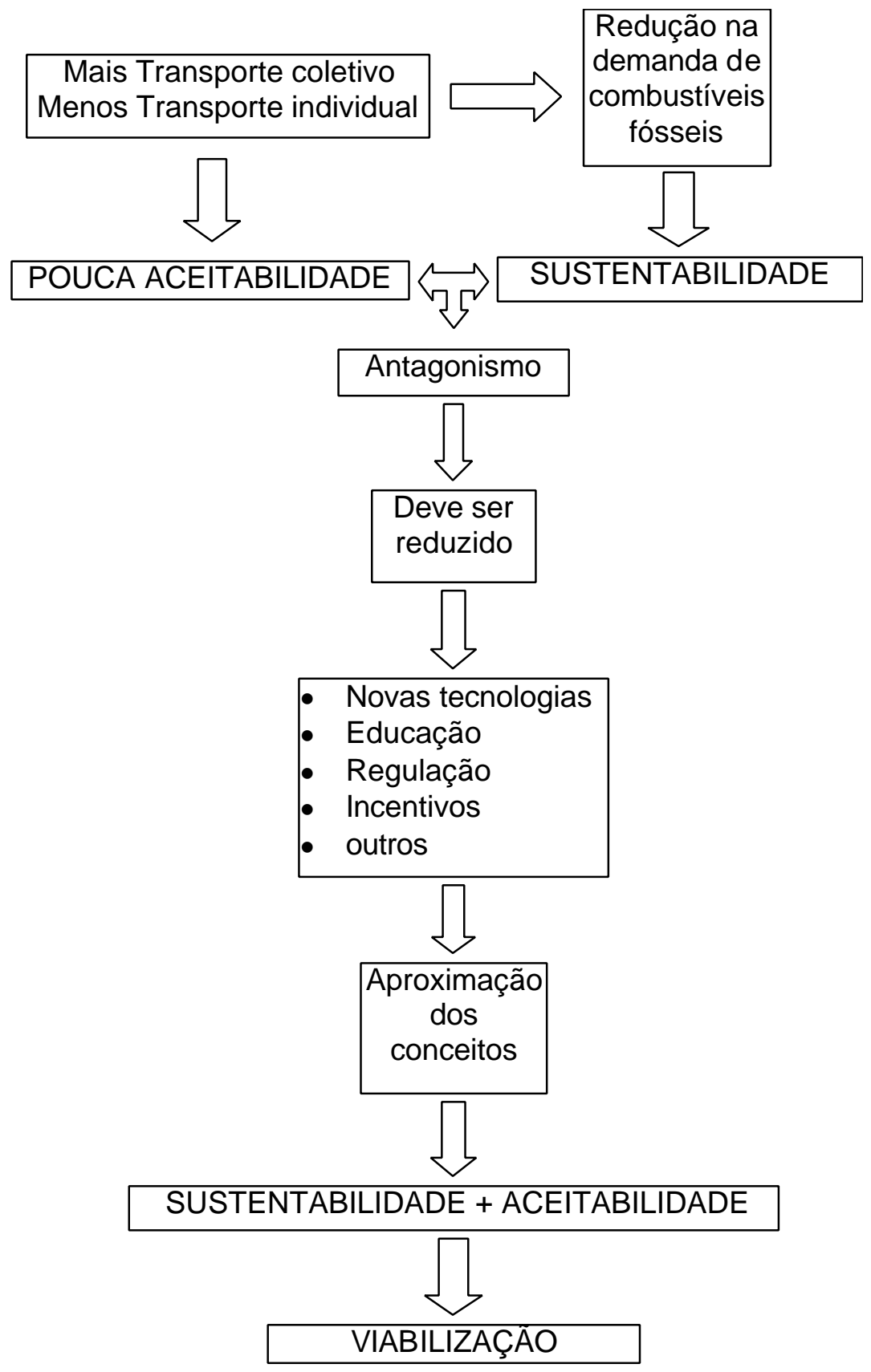

Figura 3.1: Aceitabilidade e Sustentabilidade: Viabilização de Projetos

A aceitabilidade tem uma forte componente política, mas, conforme será visto adiante, os maiores conflitos relativos à aceitabilidade estão relacionados ao aspecto econômico. 
O grande desafio é a conciliação dos interesses individuais com as metas globais de sustentabilidade, tornando a busca desta última uma meta aceitável e portanto factível.

A seguir serão melhor detalhados aspectos destes dois conceitos.

\subsection{Sustentabilidade: Barreiras e Incentivos}

O conceito de sustentabilidade já foi abordado no capítulo 2 porém será retomado aqui sob o enfoque da aceitabilidade. O texto a seguir é um extrato da [Ref. 16], à qual se remete para um maior aprofundamento do tema.

Quando se trata da infra-estrutura sob o enfoque da sustentabilidade, deve-se considerar que, para a maioria dos seus componentes, é no seu uso onde se identificam os maiores impactos sobre a sustentabilidade.

No aspecto da estrutura em si, a sua construção implica em:

$\checkmark$ Imobilização da terra;

$\checkmark$ Diminuição de recursos finitos em construções;

$\checkmark$ Disposição do lixo e entulhos;

A imobilização da terra se constitui em um importante tema de discussão quando se trata de sustentabilidade e aceitabilidade.

Como exemplo, pode-se citar o uso de biomassa para geração de energia elétrica, que, embora apresente diversos aspectos ambientais positivos, ocupa a terra de maneira permanente. 
Os ambientalistas argumentam que a escassez de terras pode elevar 0 preço de alimentos, o que interfere diretamente na aceitabilidade do empreendimento.

Pensando-se na construção e disposição de lixo, a sustentabilidade pode ser alcançada por um método perpétuo e regenerativo ou através do reuso, ou reciclagem. A construção da infra-estrutura deve considerar o uso de materiais recicláveis e reciclados como formas de buscar a sustentabilidade já na etapa construtiva, já com vistas a eventual futura disposição no meio ambiente.

Quando se pensa no uso a longo prazo, a provisão de infra-estrutura deve-se preocupar com:

- Consumo de recursos não renováveis ( $p$ ex. petróleo e gás natural).

$\checkmark$ Aumento deste consumo, emissões de poluentes a uma taxa maior que a capacidade de absorção pela natureza;

$\checkmark$ Emissão de compostos químicos naturais a uma taxa tal que desbalanceem o ecossistema $\left(\mathrm{CO}_{2}\right)$;

$\checkmark$ Emissões de CFCs;

$\checkmark$ Emissões de $\mathrm{NO}_{x}$ e $\mathrm{SO}_{x}$;

$\checkmark$ Consumo de minerais como combustíveis

Em conformidade com o anteriormente exposto, a busca da sustentabilidade deve procurar: 
- Mudança no padrão de comportamento. Por exemplo: mais transporte coletivo e menos individual;

- Processos limpos, redução de emissões;

- Uso mais eficiente dos recursos, o que no caso específico da energia elétrica consiste, por exemplo, na aplicação de técnicas de Gerenciamento pelo Lado da Demanda, [Ref. 29].

A sustentabilidade pode ainda ser atingida com diferentes níveis de qualidade.

Assim, uma estrutura de saneamento pode ser feia e mal cheirosa (pouco aceitável), mas pode ser sustentável.

Para se atingir a sustentabilidade, há que se atuar na legislação, regulação, educação, forças de mercado, ciência, econômica e sociologia, de onde se conclui que a sua busca efetiva é uma questão política.

A maneira mais poderosa e efetiva é a educação, que pode operar mudanças de atitude na população como um todo.

A mudança requerida é profunda, indo além da compreensão do conceito de sustentabilidade e promovendo o desejo de atuar positivamente, através da mudança de seu modo de vida, para atingir-se os objetivos concernentes à sustentabilidade.

Esse objetivo demanda mudanças na educação, que deve incluir ciência e tecnologia e as ciências humanas. A sustentabilidade requer um número maior de pessoas com uma educação global. 
Paralelamente à educação, existem as não menos importantes forças de mercado.

O mercado, por si só, não buscará a sustentabilidade ambiental, pois seu objetivo é a sustentabilidade financeira.

Se os objetivos ambientais forem incorporados às forças de mercado, direta ou indiretamente deverá ser colocado um valor aos objetivos que se pretende atingir.

Embora seja difícil estabelecer-se objetivos quantitativos, eles são necessários para que se proceda a uma análise do que foi atingido por medidas já implantadas. Deve-se tomar cuidado para não enganar a próxima geração em termos ambientais, com medidas que só garantem a sustentabilidade aparentemente.

Medidas fiscais e regulatórias podem se prestar ao papel de fomentar a busca da sustentabilidade ambiental.

Algumas considerações devem ser feitas em relação a estas medidas:

- As medidas fiscais devem ser implantadas ao longo dos anos, para evitar o impacto negativo da impopularidade e, ainda, para que tanto as indústrias como a população possam se conscientizar dos objetivos pretendidos.

- As medidas regulatórias devem ser tomadas mais rapidamente para incentivar respostas criativas.

- É difícil mobilizar a opinião pública em defesa do meio ambiente. Os planos devem ter motivações outras que não só a ambiental. 
- A abordagem deve ser a de se buscar o possível, não deixando que a perfeição conceitual se torne inimiga da atuação prática.

- A atuação governamental deve buscar medidas de aplicação barata, aceitáveis e pouco burocráticas.

- A sustentabilidade ambiental não será conquistada com penalidades e arbitrariedades financeiras. Por exemplo, pode-se estabelecer limites decrescentes de tolerância à emissão de poluentes para determinado tipo de indústria

O desempenho ambiental da indústria geralmente tem sido pensado em termos de proibição e penalidades.

Também é útil pensar-se em termos de incentivos, particularmente no caso dos tomadores de decisão dos negócios, que não irão desviar-se do seu objetivo de lucro ótimo, apenas por altruísmo.

O uso de taxações como instrumento para sustentabilidade deve ser encarado com muito cuidado, não devendo implicar em um aumento geral de impostos.

Dessa forma, se os encargos aumentam em uma área, devem, automaticamente, serem reduzidos em outra. Por exemplo, a transferência de impostos no salário e no lucro, para emissão de poluentes, para o uso de recursos, energia, etc..

Outro aspecto de extrema importância ao se considerar os métodos de redução da demanda (como caminho para sustentabilidade) é o do atendimento aos mais pobres. A simples taxação de bens e serviços pode 
simplesmente criar uma barreira intransponível, impedindo determinadas camadas da sociedade de usufruírem de bens essenciais. Assim, taxações devem primeiro ser introduzidas gradualmente, para que todos possam adaptar-se à nova realidade. Segundo, para determinados setores deve haver uma compensação que mitigue os efeitos da taxação. Caso contrário, a taxação poderá se tornar um fardo que conduzirá à destruição do meio ambiente. Isto tem sido comprovado em diversos locais, onde a falta de acesso à infra-estrutura e o desenvolvimento tem conduzido a população desfavorecida à práticas depredatórias ao meio ambiente, tais como o extrativismo de madeira ou mesmo a poluição conseqüente da falta de saneamento. Um exemplo deste fato, que será retomado no capítulo 5 , é o extrativismo predatório da palmeira juçara, nativa da Mata Atlântica brasileira. O extrativismo predatório (há também o extrativismo ecológico) está levando-a à extinção, com sérios danos à fauna e flora deste ecossistema. Esta prática predatória está baseada principalmente no fato das populações carentes terem como único meio de subsistência a venda do palmito extraído da mata.

\subsubsection{O Papel das Partes Políticas}

O governo irá encontrar dificuldade em implementar medidas como o aumento de impostos ou taxações, pois a oposição deverá tirar vantagem política do fato.

Porém, para que se alcance a sustentabilidade, são necessárias políticas fiscais e regulatórias de longo prazo, não podendo ser apenas decisões de caráter individual de cada uma das partes em um jogo político. 
As partes devem concordar ao menos com programas e objetivos de longo prazo.

Aqui insere-se o conceito de políticas de Estado, que estão acima das de governo. Ou seja, devem existir políticas de longo prazo que estejam acima das políticas momentâneas, que são sujeitas às práticas dos políticos ou governantes.

Um acordo deste tipo é difícil e demandará recursos financeiros para alcançar resultado. O fato é que a sustentabilidade requer capital para ser alcançada.

Via de regra, a obtenção de fundos para realização de obras em infraestrutura não é uma tarefa fácil e a busca da sustentabilidade pode ser ainda mais complicada. O meio ambiente deverá concorrer com objetivos de primeira necessidade, como por exemplo a necessidade que os governos vão ter de contornar problemas previdenciários (devido à tendência de crescimento da população idosa).

Um conceito interessante a respeito da provisão de infra-estrutura com vistas à sustentabilidade é o do inglês [Ref. 16] BATNEEC (Best Alternative Techniques Not Entailing Excessive Costs), ou melhores técnicas disponíveis que não requerem custos excessivos, cujo conceito foi amplamente aceito no Reino Unido, por todos os entes políticos. Este conceito prevê a utilização de técnicas eficientes que não implicam em um encarecimento excessivo do serviço em pauta, o que determinaria uma menor acessibilidade do mesmo e portanto com implicações negativas para o meio ambiente e para a sociedade. 
Trata-se de adequar as necessidades relativas à sustentabilidade à factibilidade das mesmas.

\subsubsection{Padrão de Vida}

O padrão de vida está intimamente ligado à sustentabilidade. Isto porque é ele, em primeira instância, quem define a quantidade de energia e recursos gastos (e todas as suas conseqüências para o meio ambiente) por habitante. É difícil que os países em desenvolvimento abracem a causa da sustentabilidade se isto implicar de alguma forma na redução ou manutenção do seu já inadequado padrão de vida. O mesmo ocorre com os países desenvolvidos, cuja população já mostrou não aceitar redução de qualquer natureza neste item.

Neste contexto, a busca da sustentabilidade sem queda no padrão de vida do indivíduo passa, necessariamente, pelo desenvolvimento de novas tecnologias. Isto deverá ocorrer nos mais diversos campos: agricultura, reflorestamento, água, recriação do habitat, comunicações, transporte, redução da poluição, reciclagem, fontes renováveis, etc.

As perspectivas neste campo são promissoras, mas reforçam a idéia de que se deve criar mecanismos (regulatórios, fiscais, etc.) que incentivem a busca acelerada destas novas tecnologias.

Embora essa mudança de paradigma possa ser vista como uma carga a mais para sociedade e especialmente para a indústria (aceitabilidade), por outro lado ela representa o surgimento de novas oportunidades de negócios. 
Em breve haverá grandes volumes de capital disponíveis para empresas e/ou países que tiverem desenvolvido tecnologias que conduzam à sustentabilidade. Será então criado um novo mercado, cuja criatividade e investimento em pesquisa e desenvolvimento serão fundamentais.

\subsection{Aceitabilidade: Variável Básica para Viabilizacão de Projetos}

Para os ambientalistas, o que é sustentável deve definir o que é aceitável.

Para a maioria da população, sustentabilidade é um conceito desconhecido e não determinante da aceitabilidade. Inclusive este tem sido o motivo pelo qual diversas medidas que visam a sustentabilidade são inviabilizadas, pois incorrem na não aceitação pela opinião pública.

A divergência atual entre sustentabilidade e aceitabilidade tem sido um dos maiores entraves à tomada de decisões no sentido da primeira. Somente com a educação em massa e o passar dos anos ambas poderão andar juntos para a maioria das pessoas, momento este em que a busca da sustentabilidade será facilitada através da redução de tempo e custos na implantação de medidas neste sentido.

A aceitabilidade tem uma componente política muito forte, relacionada a factibilidade. Um projeto pode ser aceito por $95 \%$ da população, mas se os outros $5 \%$ se opuserem vigorosamente e dispuserem de recursos para tal, provavelmente tornarão o projeto inviável. 
Há dois aspectos que devem ser considerados nesta questão: a) de que as pressões das minorias devem ser suplantadas pela maioria e; b) ao contrário, de que o bem estar social tem sido controlado pelas minorias e os políticos deveriam estar abertos à persuasão.

Esta última abordagem pode tornar determinados projetos mais aceitáveis por parte de seus oponentes.

Isto é especialmente importante quando se considera a quantidade de tempo e dinheiro gastos em uma disputa judicial contra determinada medida ou empreendimento. Tais recursos seriam bem melhor empregados caso fossem direcionados à medidas e estruturas que apresentassem um uso produtivo e/ou ambiental.

As divergências em torno de empreendimentos podem atrasá-los em anos, consumindo considerável quantia de tempo e dinheiro, de ambas as partes integrantes da disputa.

Conflitos internos à sociedade são destrutivos inclusive à saúde da população, o que se reflete negativamente na busca da sustentabilidade.

Além disso, todo o dinheiro e esforços gastos poderiam ser melhores direcionados à saúde, educação, programas ambientais ou simplesmente redução do fardo fiscal sobre o contribuinte. O que tem efeito imediato sobre a problemática do acesso à infra-estrutura pela população de baixa renda.

Os projetos de infra-estrutura necessitam de processos de audiências públicas, que costumam levar até 2 anos para a avaliação detalhada de prós e contras. 
A análise de aceitabilidade, em um primeiro plano de sua consideração, tem como meta reduzir estes tempos, sem prejuízo da qualidade ambiental do projeto.

Através desta abordagem espera-se diminuir os já conhecidos custos de planejamento dos projetos. No Reino Unido, espera-se reduzir em $50 \%$ os custos com audiências públicas em 5 anos e mais $50 \%$ nos 5 anos seguintes.

O custo com processos judiciais deve ser reduzido à zero, pois não agrega valor algum aos projetos.

\subsubsection{A Busca da Aceitabilidade}

Os projetos de infra-estrutura necessitam ser construídos. Como então diminuir os protestos e a objeção, tornando-os aceitáveis?

Há dois grupos de objeção à projetos. Aqueles que lutam (ou acham que o fazem) por um meio ambiente sustentável e aqueles que lutam por uma gama de razões individuais (onde se inclui o ganho financeiro).

$\mathrm{Na}$ busca da sustentabilidade deve-se conduzir os projetos para a aceitação ambiental dos mesmos, o que reduzirá a objeção dos grupos ambientalistas e manterá o objetivo de sustentabilidade.

Para que isto aconteça deve-se estabelecer uma situação onde os ambientalistas confiem nas políticas governamentais. Estes grupos precisam considerar que seus objetivos podem ser melhor alcançados desta maneira do que através de oposição permanente. 
A idéia é economizar grandes somas de dinheiro gastas em batalhas judiciais, através da melhora da aceitabilidade do empreendimento.

Se houver uma confiança geral, a aceitabilidade poderá ser vista segundo dois enfoques: com foco no balanço entre vantagem para as pessoas e desvantagem ambiental e com foco em um esquema com maior sensibilidade ambiental, dentro da factibilidade.

Um aspecto da aceitabilidade é enfatizar os benefícios. Por exemplo, uma rede de estradas construídas é crucial para o bem estar econômico do país. Reservatórios, que ocupam a terra, são essenciais para manter o suprimento da água.

Em termos ambientais, o uso da terra pela infra-estrutura geralmente não é crítico. Porém, seria ingênuo acreditar que, na visão de médio ou longo prazo, as terras produtivas não terão nenhum valor.

A preocupação com o meio ambiente deve ser considerada em larga escala e embora tal custo seja elevado, ele compõe a valoração econômica da destruição do meio ambiente.

A emissão de poluentes aéreos ou líquidos é certamente um vetor de degradação da qualidade de vida.

A busca da sustentabilidade é um objetivo ambiental diferente da manutenção da qualidade de vida, a despeito da maioria das pessoas, que desejam o primeiro e querem também melhorar o segundo. 
Essas questões constituem uma importante parte da aceitabilidade relacionada à projetos individuais. Compõem também parte necessária da abordagem de impactos ambientais e debates em audiências públicas.

Em alguns casos, o pagamento de uma compensação financeira é necessária. A compensação por danos deve ser justa para ambos os lados, as políticas que estabelecem pagamentos não maiores que os danos têm-se mostrado melhores.

Um problema importante está relacionado às incertezas ao longo dos anos, tanto no planejamento quando nas políticas de implantação.

\subsubsection{O Processo de Planejamento}

O processo de planejamento pode ser um fator de aceitabilidade, particularmente nas audiências públicas.

As audiências públicas, geralmente adquirem alto grau de antagonismo. As visões tendem a se polarizar e as posições a se enrijecerem.

O desenvolvimento aceitável requer um balanço que leve em consideração as opções de desenvolvimento, bem como seus benefícios e malefícios. Devem-se incluir os efeitos econômicos completos bem como considerações sobre a sustentabilidade e o meio ambiente.

A aceitabilidade depende de uma abordagem mais colaborativa que competitiva (adversários) no processo de audiências públicas. Deve-se proceder um processo de diálogo, o que implica em esforço para se 
empreender um processo de planejamento aberto, criando-se mais de uma opção a ser apresentada nas audiências públicas.

A idéia de oferecer duas ou mais opções pode parecer uma receita para se gastar mais tempo e dinheiro, entretanto o processo pode levar menos tempo.

O objetivo principal deste conceito é levar o público a escolher um melhor caminho, dadas duas alternativas, ao invés de apenas se opor a uma única solução apresentada.

No planejamento, a consideração apenas da análise de custo benefício é insuficiente, devendo-se incluir os benefícios e a sustentabilidade. Aqui recaise na problemática de se converter os danos e ou assistência à sustentabilidade em valores monetários, para que possam ser pesados contra outros fatores.

Este se constitui por si só em um vasto campo de estudo, mas que é absolutamente necessário para o estabelecimento de métodos de comparação.

Vê-se desse modo que o conceito de aceitabilidade deve ser incorporado já no processo de planejamento, pois é nesta etapa onde se pode administrar de maneira mais efetiva os conflitos em torno de determinado empreendimento em infra-estrutura. Um processo de planejamento que já incorpora tais características é o Planejamento Integrado de Recursos, para o qual se remeta à [Ref. 8]. 


\subsection{A Viabilização dos Projetos Através de uma GIR - Gestão Integrada de Recursos}

A GIR deve considerar, como já foi dito, a viabilização sustentável de projetos em infra-estrutura, seja melhorando os que já são viáveis seja viabilizando os que ainda não o são, sob os aspectos: econômico, social, ambiental, político e tecnológico.

A viabilização econômica deve ser a primeira a ser satisfeita, pois, para que se possa contar com a participação de investidores do setor privado, o projeto deve ser sustentável neste aspecto.

Do ponto de vista estritamente econômico, a sustentabilidade ambiental implica em desvio do ponto ótimo, pois requer investimentos adicionais em todas as etapas do empreendimento: implantação, operação e manutenção.

Este fato reflete na aceitabilidade econômica do empreendimento.

Além disso, por diversas razões já salientadas, existem problemas relacionados à aceitação social. Seja por motivos da estrutura ou o seu uso que podem implicar em deterioração de determinado local, seja pelo próprio aspecto econômico relacionado ao seu uso.

A GIR deve permitir a minimização destes inconvenientes, o que pode ser feito de diversas formas:

a) Através da busca de redução de custos na provisão de serviços ou infra-estrutura, através da integração dos mesmos. Isto deve permitir a melhora da aceitabilidade econômica dos empreendimentos por 
parte dos investidores. Esta redução deve permitir também a redução de tarifas, melhorando a aceitabilidade (e consequentemente o acesso) por parte da população.

b) Esta integração deve ser feita de modo a se minimizarem os impactos ambientais da inserção da infra-estrutura, através da busca da redução da estrutura construída para provisão dos mesmos serviços. Esta abordagem deve melhorar a aceitabilidade ambiental e consequentemente reduzir custos com batalhas judiciais, recuperação ambiental, aprovação de EIA RIMA;

c) Quando inserida no processo de planejamento, a GIR deverá constituir uma segunda opção em relação a abordagem convencional, melhorando os processos de audiências públicas, conforme explicado anteriormente;

d) A GIR deve permitir a inserção de serviços de caráter social em projetos de viabilidade econômica comprovada. Esta possibilidade implica na junção da aceitabilidade econômica com a social, podendo, ao mesmo tempo, tornar um projeto aceitável econômica e socialmente. A aceitabilidade ambiental já deverá estar inserida neste contexto. Dessa forma também pode se fomentar a realização de obras de caráter social por parte do setor privado, com a motivação da melhora na aceitação de projetos cuja finalidade maior é a econômica. 
A análise integrada dos empreendimentos em infra-estrutura, procurando viabilizar a provisão dos serviços vai ao encontro da busca da aceitabilidade.

A GIR deve procurar se valer do novo paradigma, onde o Estado exerce mais efetivamente o papel de regulador e, quando necessário, de financiador, deixando para o setor privado as funções de empreendedor e administrador.

Através deste papel é possível criar condições para que o setor privado se sinta interessado em investir na infra-estrutura. Devido à maior flexibilidade, "know-how" e agilidade deste, em comparação ao Estado, os aspectos que comprometem a aceitabilidade, tratados neste texto, são evitados ou mais facilmente contornados.

Por outro lado, a busca da sustentabilidade (não só econômica) ficará a cargo do Estado, através de políticas e regulação de longo prazo, que deverão incorporar a linha da sustentabilidade. Esta abordagem deixa claro o papel de cada ente participante do processo e permite que se atinja o equilíbrio harmônico entre as partes mais facilmente.

A população terá como resultado serviços de melhor qualidade, e a regulação deverá garantir que tais serviços sejam mais acessíveis que no panorama atual.

Com cada parte exercendo sua real competência, pode-se esperar como resultado um relacionamento menos competitivo e mais colaborativo, o que, de acordo com os conceitos explanados, deve conduzir à aproximação esperada dos conceitos de sustentabilidade e aceitabilidade. 


\section{A PROPOSTA DA GESTÃO INTEGRADA DE RECURSOS}

\subsection{A Base, os Conceitos, o Desenho}

\subsubsection{Base e Conceitos}

Segundo (Lynch, 1994, [Ref. 10]), no mercado globalizado, as empresas devem buscar o crescimento como forma de evitar a sua própria extinção. Uma das formas de se garantir o crescimento do negócio são as alianças estratégicas, que se constituem em uma poderosa arma competitiva, pois requerem poucos recursos em espécie e podem ser realizadas com rapidez, formadas horizontalmente ou verticalmente.

Analogamente, o Banco Mundial [Ref. 1] aponta que, no futuro, os governos precisarão da parceria de empreendedores privados.

Seguindo esta linha, a Gestão Integrada de Recursos - GIR, deve procurar nas alianças e parcerias, vantagens na implantação e operação de componentes da infra-estrutura. Busca-se, na associação da infra-estrutura e/ou serviços, vantagens (construtivas ou operativas) que garantam a competitividade econômica e a viabilização do investimento.

Entre outras, podem-se ter as seguintes vantagens:

$\checkmark$ • Otimização da implantação, operação e serviços;

$\checkmark \square$ Possível redução de tarifas, aumentando o acesso à infra-estrutura pelos mais pobres;

$\checkmark$ Redução de danos ao meio ambiente, por permitir, em alguns casos, a redução de estruturas redundantes para prestação de serviços diferentes; 
$\checkmark$ Diversificação dos serviços prestados;

$\checkmark$ Melhor posicionamento estratégico da empresa, pois permite a ampliação de sua fatia de mercado;

$\checkmark$-Diminuição da barreira do capital inicial, que fica diluído entre os participantes;

$\checkmark$ Divisão de riscos associados aos investimentos.

Através desta abordagem, partes da infra-estrutura sabidamente viáveis podem ser associadas à outras que, sozinhas, seriam economicamente inviáveis, mas são socialmente necessárias.

A GIR deve olhar para a busca da eficiência econômica e financeira na implantação da infra-estrutura, olhando para diversas demandas por serviços e identificando os mais rentáveis, os socialmente mais necessários e a possível associação entre parceiros e componentes da infra-estrutura que possam suprir tais serviços.

A associação de parceiros é orientada a partir da identificação da sinergia (construtiva ou operativa) entre os componentes da infra-estrutura e serviços, bem como entre os entes investidores e possíveis beneficiados.

Tal abordagem deve perseguir a sustentabilidade dos investimentos, através da autonomia econômica dos empreendimentos, recorrendo-se à atuação do Setor Público apenas nos casos em que determinados componentes da infra-estrutura são socialmente necessários mas não são rentáveis. A atuação governamental pode ocorrer através de parceria, incentivos, subsídios, criação de mecanismos, etc.. Neste contexto, as 
Agências Regulatórias terão papel preponderante, pois deverão priorizar os interesses coletivos resguardando os interesses dos entes participantes do projeto.

A GIR, segundo o modelo considerado como base para este desenvolvimento (Reis e Mielnick, 1999, [Ref.4], ANEXO 1), deverá ser operacionalizada a partir da harmonização de duas concepções: a) a visão empresarial, que pretende a realização do lucro, considerando o papel e as atribuições dos investidores; b) a visão institucional, com ênfase na defesa dos interesses coletivos e na atuação dos agentes reguladores dos serviços de infra-estrutura.

Vale lembrar que parte da infra-estrutura é provida, até agora, em caráter obrigatório pelos governos, que na visão da GIR poderiam obter vantagens com a associação entre si (p. ex. municipal e estadual) ou com o setor privado.

Ainda com vistas à sustentabilidade, todo o planejamento da GIR deve levar em conta o critério ambiental. Neste sentido, a associação de estruturas, pode reduzir impactos ambientais, uma vez que uma estrutura integrada, i.e., que proporciona mais de um tipo de serviço, pode ser menor que outras separadas para provisão dos mesmos serviços.

Resumidamente, a GIR tem como base a vantagem de tornar investimentos agregados viáveis do ponto de vista econômico, social, ambiental, político e tecnológico em projetos que, isoladamente, seriam inviáveis em algumas destas vertentes. 
No contexto brasileiro, a nova ordem, baseada em (Reis e Mielnick, 1999, [Ref.4]), a) reorganização institucional dos setores relacionados à infraestrutura (energia, transportes, telecomunicações, água e saneamento básico); b) incentivo à aplicação de capitais privados nos mesmos setores e; c) criação das agências reguladoras, cuja missão é, entre outras coisas, a de assegurar a qualidade dos serviços públicos em benefício da população e a de viabilizar projetos de interesse público, por critérios que preservem os interesses do conjunto dos participantes, incluindo os órgãos governamentais, as empresas e os seus investidores; possibilita o surgimento de oportunidades de negócios passíveis da abordagem da Gestão Integrada de Recursos. A GIR, segundo os autores é ainda justificada pelos seguintes motivos:

$\checkmark \square$ A importância de estabelecer-se mecanismos que incentivem a utilização integrada e mais adequada dos recursos disponíveis em uma dada região, de forma a estabelecer uma estratégia de desenvolvimento sustentável que elimine desperdícios, se harmonize com o meio ambiente e promova a equidade;

$\checkmark \square \mathrm{A}$ necessidade de uma visão holística e multidisciplinar dos principais vetores de infra-estrutura relacionados com o desenvolvimento e sua sustentabilidade: energia, telecomunicações, transporte, água e saneamento básico.

$\checkmark \square$ A necessidade de viabilizar a aplicação de conceitos que relacionem a utilização integrada de recursos, a exploração de sinergias potenciais e o 
desenvolvimento sustentável, de uma forma prática e atrativa para investidores privados.

$\checkmark \square$ processo de reestruturação e de reforma institucional dos serviços públicos de infra-estrutura no País, o que cria oportunidades para a introdução de novos debates, procedimentos e propostas

$\checkmark$ $\square$ identificação, no País, de diversas áreas e regiões, onde o desenvolvimento tem sido inviabilizado, principalmente por falta de investimentos nos serviços de infra-estrutura, resultando em menos investimentos e em redução cada vez mais acentuada da atividade econômica.

$\checkmark$ $\checkmark$ A viabilização da possibilidade de estabelecer unidades de negócio em consórcio, com gestão unificada, permitindo a utilização integrada dos recursos da região de modo que o melhor uso dos recursos (interesse da comunidade) esteja associado a oportunidades atrativas aos investidores privados.

\subsubsection{O Desenho}

O primeiro aspecto que deve ser analisado na associação dos componentes da infra-estrutura é o econômico, para que se garanta a autonomia do investimento. Desta forma, deve-se primeiramente identificar a viabilidade econômica dos componentes, diferenciando-os por este critério.

Para os menos rentáveis deve-se analisar a necessidade social dos mesmos, e, em ambos os casos, deve-se identificar o tipo de atuação para 
cada caso - dos setores privado e público. Aqui serão analisados os possíveis mecanismos compensatórios.

Uma vez identificados os componentes potencialmente rentáveis ou socialmente mais necessários, deve-se buscar a sinergia entre estes, quanto às suas características construtivas ou operativas.

Com tais etapas concluídas, pode-se partir para a identificação de possíveis associações de componentes da infra-estrutura que se desejam para um local. Nesta etapa, o escopo da análise deve ser fechado em torno do que se pretende aplicar e então pode-se identificar possíveis parceiros.

De acordo com as características do empreendimento e dos possíveis parceiros deve-se escolher ou propor a melhor forma de associação entre estes, compondo a etapa de definição do tipo de parceria.

Deve-se então verificar as possíveis vantagens da GIR nos aspectos: Econômico, Ambiental e Social, verificando sua consistência perante os aspectos político e tecnológico.

A viabilidade econômica é então analisada de acordo com o lucro obtido com a associação em comparação com o que seria obtido separadamente.

A social é analisada em função de benefícios à população, comércio e indústria, que tais empreendimentos venham a trazer, bem como ao Setor Público, através da arrecadação de impostos.

A viabilidade ambiental se concretiza pela redução de impactos ambientais em relação à implantação isolada, ou decorrente da introdução de 
serviços que reduzam impactos deste tipo. Esta proposta da GIR pode ser melhor visualizada no diagrama da Figura 4.1.

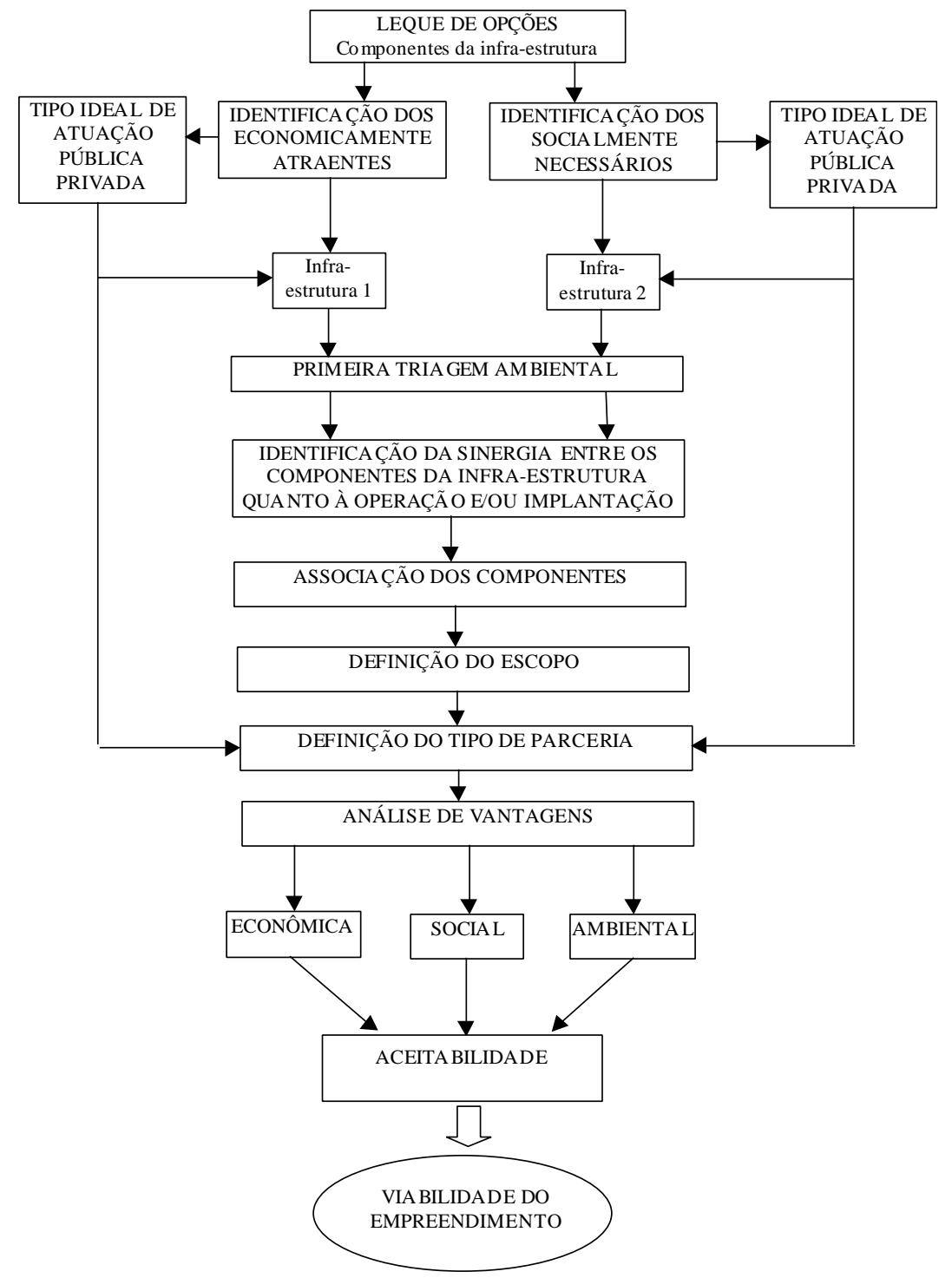

Figura 4.1: Diagrama Básico da Gestão Integrada de Recursos

\subsection{A Modelagem}

Seguindo o encaminhamento do diagrama da Figura 4.1, passa-se, a seguir, ao desenvolvimento de cada uma e suas etapas. 
Conforme será visto, muitas delas se intercalam e se completam em suas análises.

A ordem que se segue não deve ser encarada de maneira rígida, pelo contrário, todo o processo deve ser desenvolvido da maneira mais paralela possível, para que os resultados de determinadas análises possam enriquecer o de outras.

\subsubsection{Leque de Opções}

Como já mencionado, o leque de opções considerado envolve os cinco componentes básicos da infra-estrutura : Energia Elétrica, Telecomunicações, Água e Saneamento, Tratamento do Lixo e Transporte.

Como parte da orientação quanto à identificação e escolha dos componentes mais adequados da infra-estrutura, de acordo com a sinergia entre estes e os entes que eles afetam, é necessário estabelecer uma relação entre tais componentes e o resultado empresarial (vertente comercial) e os indicadores sociais (vertente social). Dessa forma será possível obter elementos que ajudem no processo de identificação de possíveis potenciais de sinergia entre os componentes da infra-estrutura e os entes que estes afetam, buscando uma relação de causa e efeito entre os objetivos que se pretendem alcançar e a implantação da infra-estrutura.

Para tanto foram construídas as Tabelas 4.1 e 4.2, cujo objetivo principal

é qualificar os impactos causados pelos componentes da infra-estrutura nos Indicadores Sociais e sobre o Resultado Empresarial, mostrando se os 
mesmos são diretos, ou indiretos. Em seguida, tem-se um melhor detalhamento sobre as tabelas.

Tabela 4.1 : Qualificação de Impactos nos Indicadores Sociais

\begin{tabular}{|l|l|l|l|l|l|l|}
\hline $\begin{array}{c}\text { Componentes da } \\
\text { infra-estrutura }\end{array}$ & \multicolumn{5}{|c|}{ INDICADORES SOCIAIS } \\
\hline & $\begin{array}{c}\text { Acesso à } \\
\text { qualidade } \\
\text { de vida }\end{array}$ & $\begin{array}{c}\text { Saúde e } \\
\text { Saneamento }\end{array}$ & $\begin{array}{c}\text { Educação } \\
\text { básica }\end{array}$ & $\begin{array}{c}\text { Aumento da } \\
\text { Qualificação }\end{array}$ & $\begin{array}{c}\text { Fixação } \\
\text { Local }\end{array}$ & $\begin{array}{c}\text { Aumento da } \\
\text { possibilidade de } \\
\text { Locomoção }\end{array}$ \\
\hline Eletricidade & & & & & & \\
\hline Água e Saneamento & & & & & & \\
\hline Transporte & & & & & & \\
\hline Lixo - Tratamento & & & & & & \\
\hline Telecomunicação & & & & & & \\
\hline
\end{tabular}

Tabela 4.2: Qualificação de Impactos no Resultado Empresarial

\begin{tabular}{|l|c|c|c|c|}
\hline \multirow{4}{*}{$\begin{array}{c}\text { Componentes da } \\
\text { infra-estrutura }\end{array}$} & \multicolumn{3}{|c|}{ IMPACTOS NO RESULTADO EMPRESARIAL } \\
\hline \multirow{4}{*}{ Eletricidade } & \multicolumn{3}{|c|}{ Resultado Empresarial } & \multirow{2}{*}{ Escoamento da Produção } \\
\cline { 2 - 5 } & Unidades Produtivas & Cooperativas & \\
\cline { 2 - 5 } & Agrícola & Urbana & & \\
\hline Água e Saneamento & & & & \\
\hline Transporte & & & & \\
\hline Lixo - Tratamento & & & & \\
\hline Telecomunicação & & & & \\
\hline
\end{tabular}

\section{Direto}

Indireto - com grande influência

Indireto - com pequena influência

Influência desprezível

As Tabelas 4.14 .2 seriam utilizadas em um primeiro nível de desenvolvimento. Em um segundo nível, mais adiantado, pode-se pensar em, por exemplo, empresas de desenvolvimento de softwares, onde as telecomunicações fariam o papel de transporte do produto software.

Dependendo do nível de desenvolvimento do país ou região, a composição dos investimentos em infra-estrutura sofre alterações significativas, como pode ser visto na figura 4.2 a seguir. 


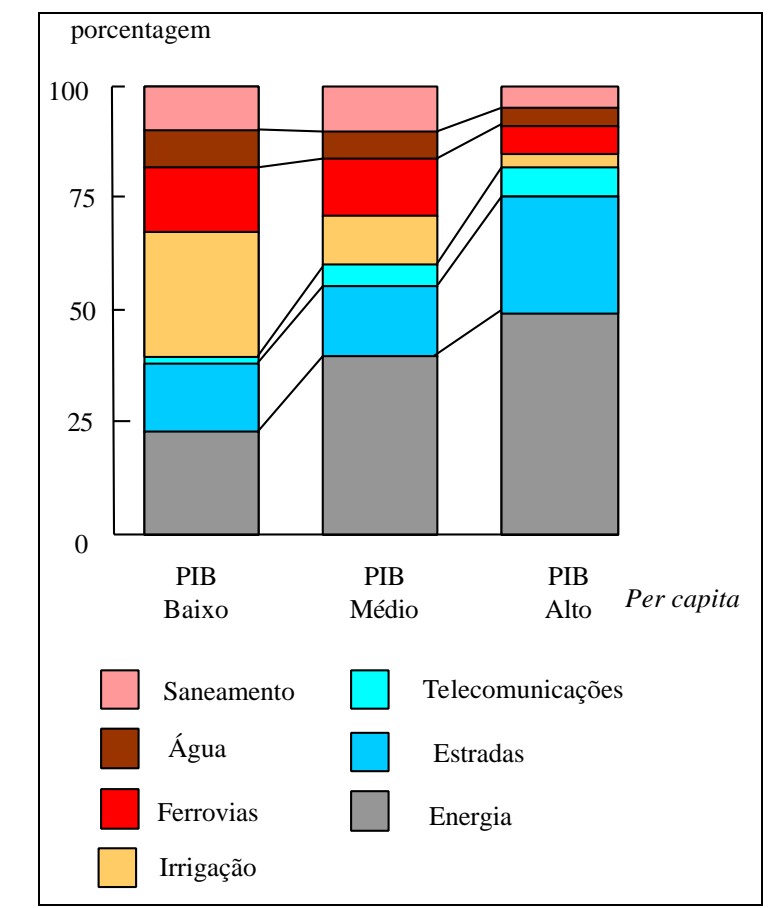

Fonte: World Development Report 1994, World Bank.

Figura 4.2: Alteração no Perfil de Investimentos em Infra-Estrutura

\subsubsection{Impactos nos Indicadores Sociais}

\section{A) Energia Elétrica}

A energia elétrica exerce influência direta sobre a qualidade de vida da população, pois permite o acesso à luz elétrica, refrigeração, informação (através da televisão, computador - internet, rádio, etc.), além de proporcionar maior nível de conforto às famílias.

Sobre a saúde e saneamento, sua influência é indireta, mas preponderante, uma vez que sua presença é necessária para que haja saneamento, embora não seja condição suficiente para o mesmo. Esta condição de influência indireta se refere à necessidade de energia elétrica para que seja possível a instalação, por exemplo, de unidades de bombeamento, 
necessárias ao saneamento (tanto para água potável como para a coleta e tratamento de esgotos).

Para a educação básica, sua influência também é indireta, uma vez que é necessária para o funcionamento de escolas. (Uma escola sem energia elétrica não apresenta condições mínimas de qualidade - iluminação adequada, acesso à equipamentos audiovisuais, computadores etc.), mas a sua presença, por si só, não é suficiente para garantir o ensino básico.

No item aumento da qualificação profissional, sua atuação é indireta com pequena influência, uma vez que não garante aumento na qualificação. Porém, pode influenciar positivamente tal fator, por permitir a ocorrência de fatores essenciais ao desenvolvimento do indivíduo, tais como: acesso à informação, melhoria na qualidade de vida, educação básica, etc. .

Na questão da fixação no local, a influência da energia elétrica é direta, pois permite condições mínimas de habitação e acesso à qualidade de vida, seja pelo uso de equipamentos essenciais como a geladeira, acesso à informação TV, ou conforto: chuveiro elétrico.

Quanto ao Aumento da Possibilidade de locomoção, sua influência é baixa, ficando restrita aos trólebus (sendo que o uso destes não se expandiu devido ao alto custo da energia elétrica), ferrovias e metrôs, presentes apenas nas grandes cidades. Este perfil pode ser alterado em um futuro onde haja 0 uso efetivo de carros elétricos. 


\section{B) Água e Saneamento}

Sua influência é direta na qualidade de vida, uma vez que a sua presença reduz a incidência de doenças sobre a população, reduz riscos de epidemias, além de melhorar a satisfação pessoal. Analogamente, o mesmo vale para a questão (correlata) de saúde e saneamento.

Na educação básica sua influência foi considerada desprezível, uma vez que sua presença, ou não, não afeta a disponibilidade, embora possa afetar a qualidade, do ensino básico. Analogamente, não influencia o $\underline{\text { Aumento da }}$ Qualificação Profissional.

Quanto à fixação no local, sua influência é direta, uma vez que sua indisponibilidade representa a falta de condições mínimas para habitação de um local.

\section{C) Transporte}

O transporte somente apresenta impactos diretos sobre o aumento da possibilidade de locomoção, pois envolve desde ruas e estradas, que compõem a infra-estrutura básica do transporte, até a disponibilidade de meios de locomoção como o transporte coletivo e o individual.

Nos demais itens, a influência do transporte é fraca, mas cabem algumas considerações.

Na qualidade de vida, sua influência é fraca, mas a sua indisponibilidade pode comprometer a mesma, gerando insatisfação. Esta avaliação se refere ao fato de que ter acesso ao transporte garante apenas o mínimo em termos de qualidade de vida. 
$\mathrm{Na}$ educação básica sua influência é mais notada na zona rural ou comunidades isoladas, por permitir o acesso das crianças à escola ou dos professores à região.

$\mathrm{Na}$ fixação no local, pode influenciar apenas na medida em que o indivíduo passa a ter acesso ao emprego e a serviços essenciais, sem a necessidade de se mudar para os locais onde estes estão disponíveis.

\section{D) Telecomunicações}

Na qualidade de vida sua influência é indireta, mas importante, dado que cada vez mais está presente na vida das pessoas, seja na TV aberta ou à cabo (que deverá em breve oferecer serviços diferenciados em comunicação, como internet) ou na telefonia, que além da voz, agora representa um meio para o transporte e a troca de dados via computador, além do acesso à internet.

$\mathrm{Na}$ saúde e saneamento, também apresenta influência indireta, mas preponderante, uma vez que o acesso à informação é, comprovadamente, uma medida eficaz no combate à certos tipos de doenças (como a Dengue) e de prevenção à outras como a AIDS e o câncer de mama.

Na educação básica sua influência é indireta mas preponderante, sendo que deverá assumir influência direta no futuro, onde a internet ou outro meio possibilitarão aulas à distância como já ocorre nas teleconferências em empresas, onde o palestrante e sua platéia estão a milhares de km de distância uns dos outros, interagindo como se estivessem na mesma sala. Tal procedimento reduz custos com deslocamento, além de melhor aproveitamento do tempo dos envolvidos e poderá ser usado para educação à distância, principalmente em locais de difícil acesso. 
Na fixação no local, sua influência é fraca, mas em regiões mais desenvolvidas, com produção basicamente intelectual, as telecomunicações podem influir na fixação, através do tele-trabalho, onde o indivíduo realiza o trabalho no seu computador pessoal e envia o resultado, via rede, para a empresa, sem necessidade de locomoção.

No aumento da possibilidade de locomoção, sua influência também é fraca, uma vez que até pode reduzir tal necessidade, como citado anteriormente.

\section{E) Lixo}

Sobre a qualidade de vida sua influência é indireta, mas preponderante, uma vez que é parte fundamental na higiene e saneamento, principalmente em zonas urbanizadas.

$\mathrm{Na}$ saúde e saneamento sua influência direta é óbvia, uma vez que reduz riscos de epidemias e doenças associadas ao acúmulo de detritos, presença de moscas e mosquitos como o da dengue, etc.

Na educação básica sua influência é demasiadamente fraca bem como na Fixação no Local, $\underline{\text { Aumento da Possibilidade de Locomoção e } \text { Aumento da }}$ Qualificação Pessoal. 


\subsubsection{Impactos no Resultado Empresarial}

\section{A) Energia Elétrica}

A energia elétrica tem impactos diretos no resultado empresarial tanto das unidades produtivas (agrícolas e urbanas) como das cooperativas, uma vez que é fundamental como energia para força motriz na produção.

No escoamento da produção, no Brasil, sua influência é desprezível, uma vez que o transporte, via de regra, é feito com base no Diesel.

\section{B) Água e Saneamento}

A água e saneamento têm influência direta no resultado empresarial agrícola e de cooperativas, principalmente na irrigação. Obviamente, no escoamento da produção não exercem influência (lembrando que o transporte fluvial encontra-se inserido no item transporte). A presença de água de boa qualidade pode também propiciar o aparecimento de indústrias de beneficiamento de produtos agrícolas, o que agrega maior valor a este tipo de produção.

Nas unidades produtivas urbanas, a água e saneamento já estão presentes e não são diferenciais no resultado empresarial .

\section{C) Transporte}

O transporte exerce influência fundamental sobre o Escoamento da Produção, o que é um fator crítico para o desenvolvimento industrial da região.

Embora seja fundamental para a indústria, sua presença não garante um bom resultado empresarial . 


\section{D) Telecomunicações}

Sua presença pode afetar o escoamento da produção diretamente, no caso de produção de caráter intelectual, como por exemplo softwares, em regiões com características de desenvolvimento mais acentuadas.

No resultado empresarial sua influência é fraca.

\section{E) Lixo}

O lixo não exerce influência tanto no aumento quanto escoamento da produção, embora a presença de um tratamento adequado de lixo possa favorecer a implantação de determinados tipos de indústrias que produzam resíduos tóxicos, que necessitam de tratamento adequado e, muitas vezes, oneroso.

\subsubsection{Análise dos Componentes da Infra-Estrutura Economicamente} Atraentes

Pensando no planejamento da infra-estrutura de uma forma empresarial, com vistas ao desenvolvimento sustentável, é necessário que, conjuntamente com os benefícios sociais e financeiros, sejam avaliados os custos que incidem sobre cada agente participante do processo. Deve-se saber as características de cada um, se são quantificáveis ou não (e neste caso se podem ser estimados e de que maneira), para posteriormente identificar-se quais investimentos trazem melhores benefícios com maior retorno do capital investido. A seguir apresenta-se uma qualificação genérica dos custos e benefícios incidentes em cada ente. Em seguida há um detalhamento sobre 
cada consideração. Deve-se notar que a classificação é genérica, e uma quantificação de cada um só é possível quando se houver determinado o escopo de um caso específico e suas particularidades (econômicas, sociais, construtivas, etc.).

\subsubsection{Custos Incidentes}

$\mathrm{Na}$ Tabela 4.3 a seguir, para cada setor da sociedade há duas subdivisões, onde a primeira trata dos custos de operação e uso (o\&u) da infraestrutura abordada e a segunda dos custos de implantação. Tal discriminação é necessária, pois alguns atores apenas participam de uma destas etapas, enquanto outros participam das duas. Além disso, o custo de operação para um envolvido pode significar o retorno de capital para outro, que participou dos investimentos apenas na implantação.

\section{Tabela 4.3: Custos Incidentes}

\begin{tabular}{|l|l|l|l|l|l|l|l|l|l|l|l|}
\hline \multicolumn{1}{|c|}{ Infra-Estrutura } & \multicolumn{2}{c|}{ População } & \multicolumn{2}{c|}{ Prefeitura } & \multicolumn{2}{c|}{ Indústrias } & \multicolumn{2}{c|}{$\begin{array}{c}\text { Empresa do } \\
\text { Setor }\end{array}$} & \multicolumn{2}{c|}{ Investidor } \\
\hline & o\&u & Imp & o\&u & Imp & o\&u & Imp & o\&u & Imp & o\&u & Imp \\
\hline Eletricidade & & & & & & & & & & \\
\hline Água e Saneamento & & & & & & & & & & \\
\hline Transporte & & & & & & & & & & \\
\hline Lixo & & & & & & & & & & \\
\hline Telecomunicação & & & & & & & & & & \\
\hline
\end{tabular}

Custos

Quantificáveis

Não quantificáveis

\section{A) Custos Incidentes Sobre a População}

> Operação, todos os componentes da infra-estrutura apresentam custos diretos mensuráveis.

- Energia elétrica: custo quantificável - conta de energia elétrica; 
- Lixo: custo quantificável - IPTU;

- Saneamento: custo quantificável - conta de água e esgoto;

- Telecomunicações: custo quantificável - conta de telefone (internet);

- Transporte: custo quantificável - passagem de ônibus, avião, trem, combustível do veículo próprio;

Implantação, geralmente não incorrem custos diretos para a população em tais itens.

\section{B) Custos Incidentes Sobre as Prefeituras}

operação

- Lixo: custos quantificáveis com operação e coleta, ainda que privatizadas;

- Áqua e saneamento: custos quantificáveis tanto no uso como na manutenção da infra-estrutura;

- Telecomunicações: custos quantificáveis no uso, através de conta;

- Eletricidade: custos quantificáveis no uso para suas instalações (edifícios, creches, escolas, etc.) e iluminação pública, através da conta;

- Transporte: podem ocorrer custos quantificáveis no subsídio em passagens de ônibus urbanos (mesmo com a operação de empresas privadas).

$\underline{\text { implantação }}$

- Áqua e saneamento: custos quantificáveis, relacionados à própria estrutura de implantação; 
- Transporte: custos quantificáveis, onde incorrem os custos de construção de pequenas estradas, ruas, terminais e pontos de ônibus, etc. ;

- Lixo: custos quantificáveis na disponibilização de terrenos para os lixões, construção de incineradores e aquisição da estrutura de coleta.

- Eletricidade: custos não quantificáveis, pois a infra-estrutura é provida por empresas específicas;

- Telecomunicações: custos não quantificáveis, a infra-estrutura é provida por empresas específicas.

\section{C) Custos Incidentes Sobre as Indústrias}

\section{operação}

- Lixo: custos quantificáveis com o pagamento da coleta e tratamento adequado;

- Áqua e saneamento: custos quantificáveis no uso, através de conta de água e esgoto;

- Telecomunicações: custos quantificáveis no uso, através de conta;

- Eletricidade: custos quantificáveis no uso para sua produção, através da conta;

- Transporte: custos quantificáveis no frete para escoamento da produção ou compra de insumos e materiais

implantação

- Áqua e saneamento: custos não quantificáveis;

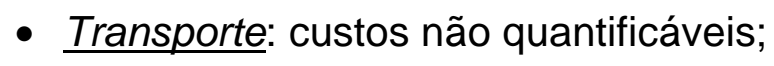


- Lixo: custos quantificáveis na disponibilização de terrenos para o acondicionamento de resíduos especiais;

- Eletricidade: custos não quantificáveis, exceto para o caso de cogeradores;

- Telecomunicações: custos não quantificáveis, exceto para estrutura própria, geralmente interna à empresa.

\section{D) Custos Incidentes Sobre as Empresas do Setor}

No caso, empresas do setor são aquelas referidas à cada infra-estrutura citada.

Por serem as responsáveis pela operação e/ou implantação da infraestrutura específica, seus custos são sempre quantificáveis, tanto na operação quanto na implantação. Em abordagens mais recentes, nas quais procura-se internalizar custos ambientais e sociais, tal premissa de custos quantificáveis tende a se alterar, dada a dificuldade de monetarização destes outros dois aspectos.

\section{E) Custos Incidentes Sobre os Investidores}

Estes caminham junto às empresas do setor e incorrem em custos diretos na implantação (que é a parte mais onerosa do investimento) porém, o investidor dificilmente é necessário na etapa de operação.

\subsubsection{Benefícios Incidentes}

A Tabela 4.4 a seguir apresenta uma qualificação de benefícios incidentes sobre a população, as prefeituras, indústrias, empresas do setor e 
investidor, quanto ao fato de serem quantificáveis ou não, e neste último, se podem ser estimados ou não.

Tabela 4.4: Benefícios Incidentes

\begin{tabular}{|l|l|l|l|l|l|}
\hline \multicolumn{1}{|c|}{ Infra-Estrutura } & População & Prefeitura & Indústrias & $\begin{array}{c}\text { Empresa do } \\
\text { Setor }\end{array}$ & Investidor \\
\hline Eletricidade & & & & & \\
\hline Água e Saneamento & & & & & \\
\hline Transporte & & & & & \\
\hline Lixo & & & & & \\
\hline Telecomunicação & & & & & \\
\hline
\end{tabular}

Benefícios

Quantificáveis Não quantificáveis

Estimáveis

Não Estimáveis

A seguir são detalhados cada um dos aspectos considerados na Tabela 4.4.

\section{A) Benefícios Incidentes Sobre a População}

- Energia elétrica: benefício não estimável numericamente - aumento da qualidade de vida, do nível de educação, etc.;

- Lixo: benefício não estimável - redução de doenças, aumento da qualidade de vida;

- Água e Saneamento: benefício não estimável - redução de doenças, aumento da qualidade de vida, redução de mortalidade infantil, etc.;

- Telecomunicações: benefício não estimável - aumento da qualidade de vida, educação (internet);

- Transporte: benefício quantificável - redução de tempo de casa para o trabalho, preço da passagem ou combustível, etc.;

\section{B) Benefícios Incidentes Sobre as Prefeituras}

- Lixo: benefício não estimável - satisfação do eleitor;

- Áqua e saneamento: benefício não estimável - satisfação do eleitor; 
- Telecomunicações: benefício não estimável - melhoria em processos de atendimento ao público;

- Eletricidade: benefício estimável - relativo ao próprio funcionamento e operação de suas instalações, além da iluminação pública;

- Transporte: benefício não estimável - satisfação do eleitor.

\section{C) Benefícios Incidentes Sobre as Indústrias}

- Lixo: benefícios estimáveis com possível redução de custos com o tratamento do mesmo;

- Áqua e saneamento: benefícios estimáveis - possibilita produção de bens de maior valor agregado, pode-se estimar que tipos de indústrias estariam impossibilitadas de operar sem o mesmo;

- Telecomunicações: benefícios estimáveis - possibilita novas oportunidades de negócios (internet), competitividade;

- Eletricidade: benefícios estimáveis - atração de indústrias mais sofisticadas;

- Transporte: benefícios estimáveis em possíveis reduções do frete para escoamento da produção (Ex. Introdução de uma malha ferroviária), melhorando a competitividade dos produtos em outras regiões.

\section{D) Benefícios Incidentes Sobre as Empresas do Setor}

Por serem as responsáveis pela operação e/ou implantação da infraestrutura específica, seus benefícios são sempre quantificáveis, uma vez que são do tipo financeiro, obtido no lucro da atuação da empresa. 


\section{E) Benefícios Incidentes Sobre os Investidores}

Novamente caminham junto às empresas do setor e obtém benefícios quantificáveis na remuneração do capital investido.

Como parte integrante da identificação dos componentes economicamente atraentes, a Tabela 4.5 contém informações da infra-estrutura do ponto de vista da comerciabilidade de cada componente, da capacidade de retorno do capital, externalidades, excelência no serviço prestado quando oferecido pela iniciativa privada ou governo, e serve como uma orientação inicial nesta identificação.

$\mathrm{Na}$ Tabela 4.5, pode-se verificar que a Energia Elétrica e as Telecomunicações são os que apresentam 0 melhor potencial de comerciabilidade, além de serem próprias para o investimento do setor privado em um ambiente competitivo. Aqui pode-se ter uma identificação prévia de componentes economicamente atraentes ao investidor e que, em uma análise posterior, podem ser integrados à componentes socialmente necessários, descritos a seguir. 


\section{Tabela 4.5: Características Empresariais dos Componentes da Infra- Estrutura}

\begin{tabular}{|c|c|c|c|c|c|c|c|}
\hline \multicolumn{2}{|c|}{$\begin{aligned} & \text { Taxa de comerciabilidade } \\
= & 1,0 \quad(\text { menos comerciável }) \\
= & 2,0 \\
= & 3,0(\text { mais comerciável })\end{aligned}$} & \multirow{2}{*}{$\begin{array}{l}\text { Potencial p/ } \\
\text { competição }\end{array}$} & \multirow{2}{*}{$\begin{array}{c}\text { Característica do } \\
\text { bem ou serviço }\end{array}$} & \multirow{2}{*}{$\begin{array}{c}\begin{array}{c}\text { Potencial de } \\
\text { recuperação c/ } \\
\text { encargos do } \\
\text { usuário }\end{array} \\
\text { Alto }\end{array}$} & \multirow{2}{*}{$\begin{array}{c}\text { Obrigações do } \\
\text { serviço público } \\
\text { (Equidade) }\end{array}$} & \multirow{2}{*}{$\begin{array}{c}\text { Externalidades } \\
\text { ambientais }\end{array}$} & \multirow{2}{*}{$\begin{array}{c}\text { Índice de } \\
\text { comerciabilidade } \\
2,6\end{array}$} \\
\hline$\dot{\delta}$ & Serviços locais & & & & & & \\
\hline$\stackrel{\bar{\Phi}}{\vdash}$ & Longa distância e valor adicionado & Alto & Privado & Alto & Pouco & Baixo & 3,0 \\
\hline \multirow{4}{*}{ 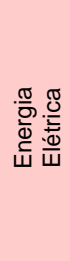 } & Geração térmica & Alto & Privado & Alto & Pouco & Alto & 2,6 \\
\hline & Transmissão & Baixo & Cota & Alto & Pouco & Baixo & 2,4 \\
\hline & Distribuição & Médio & Privado & Alto & Muito & Baixo & 2,4 \\
\hline & Produção e transmissão de gás & Alto & Privado & Alto & Pouco & Baixo & 3,0 \\
\hline \multirow{9}{*}{ 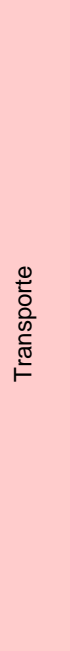 } & Trilhos e estações & Baixo & Cota & Alto & Médio & Médio & 2,0 \\
\hline & Trens de carga e passageiros & Alto & Privado & Alto & Médio & Médio & 2,6 \\
\hline & Ônibus urbanos & Alto & Privado & Alto & Muito & Médio & 2,4 \\
\hline & Trens urbanos & Alto & Privado & Médio & Médio & Médio & 2,4 \\
\hline & Estradas rurais & Baixo & Público & Baixo & Muito & Alto & 1,0 \\
\hline & Estradas primárias e secundárias & Médio & Cota & Médio & Pouco & Baixo & 2,4 \\
\hline & Estradas urbanas & Baixo & $\begin{array}{l}\text { Propriedade } \\
\text { comum }\end{array}$ & Médio & Pouco & Alto & 1,8 \\
\hline & Estruturas portuárias e aeroviárias & Baixo & Cota & Alto & Pouco & Alto & 2,0 \\
\hline & Serviços portuários e aeroviários & Alto & Privado & Alto & Pouco & Alto & 2,6 \\
\hline \multirow{2}{*}{$\frac{\pi}{3}$} & Rede encanada urbana & Médio & Privado & Alto & Muito & Alto & 2,0 \\
\hline & Sistemas não encanados & Alto & Privado & Alto & Médio & Alto & 2,4 \\
\hline \multirow{3}{*}{ 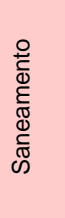 } & $\begin{array}{l}\text { Sistema de tratamento de esgoto } \\
\text { encanado }\end{array}$ & Baixo & Cota & Médio & Pouco & Alto & 1,8 \\
\hline & Esgotos de condomínios & Médio & Cota & Alto & Médio & Alto & 2,0 \\
\hline & Aterro do lixo & Alto & Privado & Alto & Médio & Alto & 2,4 \\
\hline \multirow{2}{*}{ ․ㅡㅂ } & Coleta & Alto & Privado & Médio & Pouco & Baixo & 2,8 \\
\hline & Aterro sanitário & Médio & Cota & Médio & Pouco & Alto & 2,0 \\
\hline \multirow{2}{*}{ 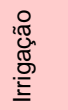 } & Redes primárias e secundárias & Baixo & Cota & Baixo & Médio & Alto & 1,4 \\
\hline & Terciária & Médio & Privado & Alto & Médio & Médio & 2,4 \\
\hline
\end{tabular}

Fonte: World Development Report 1994, World Bank. 


\subsubsection{Análise dos Componentes Socialmente Necessários}

Embora todos os componentes da infra-estrutura sejam socialmente necessários, devem-se identificar aqueles cuja necessidade se sobrepõe à interesses comerciais, onde a participação do Setor Público se faz necessária para alterar o ambiente desfavorável ao investimento privado.

A Tabela 4.6 a seguir procura estabelecer uma relação entre as competências de cada ente e suas necessidades, onde, socialmente, se destaca a população.

Tabela 4.6: Atuação x Necessidades

\begin{tabular}{|c|c|c|c|}
\hline & \multirow[t]{2}{*}{ Atuação } & \multicolumn{2}{|c|}{ Necessidades } \\
\hline & & $\begin{array}{l}\text { Que representam gastos } \\
\text { (Custos Incidentes) }\end{array}$ & $\begin{array}{l}\text { Que representam renda } \\
\text { (Resultado Empresarial) }\end{array}$ \\
\hline Prefeituras & $\begin{array}{l}\text { lluminação pública } \\
\text { Creches } \\
\text { Escolas } \\
\text { Parques } \\
\text { Praças } \\
\text { Infra-estrutura própria } \\
\text { Coleta e disposição do lixo } \\
\text { Habitação } \\
\text { Transporte }\end{array}$ & $\begin{array}{l}\text { Energia elétrica } \\
\text { Água-Saneamento } \\
\text { Telecomunicações }\end{array}$ & Impostos \\
\hline População & $\begin{array}{l}\text { Mão-de-obra } \\
\text { Impostos } \\
\text { Lucro p/ investidores } \\
\text { Lixo }\end{array}$ & $\begin{array}{l}\text { Habitação } \\
\text { Água saneamento } \\
\text { Telecomunicações } \\
\text { Energia elétrica } \\
\text { Transporte } \\
\text { Saúde }\end{array}$ & $\begin{array}{l}\text { Emprego } \\
\text { Saúde }\end{array}$ \\
\hline Indústria & $\begin{array}{l}\text { Emprego } \\
\text { Impostos } \\
\text { Investimentos } \\
\text { Agrega valor ao produto local } \\
\text { Lixo + efluentes }\end{array}$ & $\begin{array}{l}\text { Transporte } \\
\text { Energia elétrica } \\
\text { Água-Saneamento } \\
\text { Telecomunicações } \\
\text { Mão-de-obra }\end{array}$ & $\begin{array}{l}\text { Mercado consumidor } \\
\text { (estratégia) } \\
\text { Lucro }\end{array}$ \\
\hline $\begin{array}{l}\text { Investidor- } \\
\text { financiador }\end{array}$ & Viabiliza os anteriores & Sucesso dos anteriores & Retorno do capital \\
\hline
\end{tabular}




\subsubsection{Investidores $x$ Beneficiados}

A identificação clara de quem investe e de quem se beneficia, na implantação de determinado empreendimento, auxilia a etapa (posterior) de identificação de possíveis parceiros, bem como de benefícios associados (sociais e/ou ambientais). A seguir temos, resumidamente, a Tabela 4.7 de possíveis investidores e beneficiados, para cada componente da infraestrutura, e, mais detalhadamente, na Tabela 4.8, tem-se também o tipo de investimento e benefícios possíveis.

Tabela 4.7: Possíveis Investidores e Beneficiados

\begin{tabular}{|c|c|c|}
\hline & Investidor & Beneficiados \\
\hline Eletricidade & $\begin{array}{l}\text { Gerador / Transmissor } \\
\text { Concessionária / Cogerador }\end{array}$ & População / Prefeituras / Indústria \\
\hline $\begin{array}{l}\text { Água e } \\
\text { Saneamento }\end{array}$ & Prefeitura / Empresa / Estado & População / Prefeituras / Indústria \\
\hline Transporte & $\begin{array}{l}\text { Prefeitura/ Empresa / Estado / } \\
\text { Gov. Federal }\end{array}$ & População / Prefeituras / Indústria \\
\hline Lixo & Prefeitura / Empresa & População / Indústria \\
\hline Telecomunicações & $\begin{array}{l}\text { Empresa de } \\
\text { Telecomunicações }\end{array}$ & População / Prefeituras / Indústria \\
\hline
\end{tabular}


Tabela 4.8: Atores Envolvidos X Tipo de Investimentos X Tipo de Benefícios

\begin{tabular}{|c|c|c|c|c|}
\hline & Ator & Tipo do Investimento & $\begin{array}{l}\text { Capacidade de } \\
\text { Investimento - }\end{array}$ & Benefícios \\
\hline & & & & \\
\hline & Gerador & Financeiro & Alta & Financeiro \\
\hline & Transmissor & Financeiro & Alta & Financeiro \\
\hline \multirow[t]{8}{*}{ Eletricidade } & Concessionária & Financeiro & Alta & Financeiro \\
\hline & Cogerador & Financeiro & Alta & Financeiro \\
\hline & População & - & - & Qualidade de vida \\
\hline & Prefeituras & $\begin{array}{c}\text { Concessões / terrenos / } \\
\text { incentivos fiscais }\end{array}$ & - & $\begin{array}{l}\text { I.P., disponibilidade, } \\
\text { serviços, etc. }\end{array}$ \\
\hline & Indústria & - & - & disponibilidade \\
\hline & Prefeitura & $\begin{array}{l}\text { Concessões / terrenos / } \\
\text { incentivos fiscais }\end{array}$ & Baixa & \\
\hline & Empresa & Financeiro & Alta & Financeiro \\
\hline & Estado & $\begin{array}{c}\text { Concessões / Terrenos / } \\
\text { Incentivos fiscais / } \\
\text { Legislação }\end{array}$ & Média & \\
\hline \multirow[t]{5}{*}{$\begin{array}{l}\text { Água e } \\
\text { Saneamento }\end{array}$} & População & - & - & $\begin{array}{c}\text { Redução de doenças, } \\
\text { qualidade de vida }\end{array}$ \\
\hline & Indústria & - & - & \\
\hline & Prefeitura & $\begin{array}{c}\text { Concessões / Maquinário } \\
\text { / Mão de obra }\end{array}$ & Baixa & $\begin{array}{c}\text { Desenvolv. Da cidade- } \\
\text { impostos, eleitorado }\end{array}$ \\
\hline & Empresa & & Alta & Financeiro \\
\hline & Estado & $\begin{array}{c}\text { Concessões / Maquinário } \\
\text { / Mão de obra }\end{array}$ & Média & Idem à pref. \\
\hline \multirow[t]{4}{*}{ Transporte } & Gov. Federal & $\begin{array}{c}\text { Concessões Maquinário / } \\
\text { Mão de obra }\end{array}$ & Média & Idem à pref. \\
\hline & População & - & - & $\begin{array}{c}\text { Locomoção, acesso } \\
\text { ao emprego }\end{array}$ \\
\hline & Indústria & - & - & $\begin{array}{l}\text { Logística, distribuição } \\
\text { de produtos }\end{array}$ \\
\hline & Prefeitura & $\begin{array}{l}\text { Concessões / Terrenos / } \\
\text { Incentivos fiscais } \\
\text { /Maquinário / Mão de obra }\end{array}$ & Baixa & $\begin{array}{c}\text { Eleitorado, } \\
\text { cumprimento de suas } \\
\text { funções }\end{array}$ \\
\hline \multirow[t]{5}{*}{ Lixo } & Empresa & Financeiro & Alta & Financeiro \\
\hline & População & - & - & $\begin{array}{c}\text { Redução de doenças, } \\
\text { qual de vida }\end{array}$ \\
\hline & Indústria & Financeiro & Média & $\begin{array}{l}\text { Eliminação de } \\
\text { estrutura própria }\end{array}$ \\
\hline & $\begin{array}{l}\text { Empresa de } \\
\text { Telecomunicaç } \\
\text { ões }\end{array}$ & Financeiro & Alta & Financeiro \\
\hline & População & - & - & Acesso à informação \\
\hline \multirow[t]{2}{*}{ Telecom. } & Prefeituras & $\begin{array}{c}\text { Concessões / Terrenos / } \\
\text { Incentivos fiscais } \\
\text { /Maquinário / Mão de obra }\end{array}$ & - & Disponibilidade \\
\hline & Indústria & Financeiro & Média & $\begin{array}{l}\text { Disponibilidade, } \\
\text { oportunidades, internet }\end{array}$ \\
\hline
\end{tabular}


Na Tabela 4.7 pode-se notar que a atuação e necessidade dos entes (população, prefeitura, indústrias e investidores) se mesclam, pois a atuação de um supre a necessidade de outros, fechando-se um ciclo.

A atuação da prefeitura envolve ações de cunho social (necessidades da população) e para tanto necessita de impostos (renda provida pela população e indústria) e de infra-estrutura, pela qual ela deve pagar (Custos Incidentes).

A indústria necessita de infra-estrutura (parte provida pelas prefeituras) além de mão-de-obra e mercado (providos pela população).

Analogamente os investidores viabilizam os anteriores, mas dependem da possibilidade de sucesso daqueles para ter retorno do seu investimento.

Dessa forma, o aspecto social dos projetos em infra-estrutura apresenta uma componente sinérgica muito forte com o aspecto econômico. Isto porque as necessidades sociais são, em parte providas pela prefeitura e governos, e em parte pela indústria e comércio. Estando tanto a indústria como o comércio voltados basicamente ao aspecto econômico, mostra-se claramente a conseqüente sinergia entre os aspectos social e econômico. O resultado social é dependente do empresarial, e atuação do Estado (regulação) deve se dar no sentido de que, mais do que isso, um bom resultado empresarial implique em um bom resultado social.

Obviamente não está-se dizendo que a satisfação das necessidades sociais deva estar atrelada somente à resultados de análises de viabilidade econômica. O que se ressalta é que ambas as análises devem ser conduzidas de forma mais acoplada possível, dada a sinergia entre ambas . 
Neste processo de sinergia insere-se também o aspecto ambiental, que é necessidade tanto da população quanto da indústria (necessidade baseada nas exigências de mercado, regulação ambiental, etc.), completando as três vertentes básicas da análise voltada à sustentabilidade, Figura 4.3.

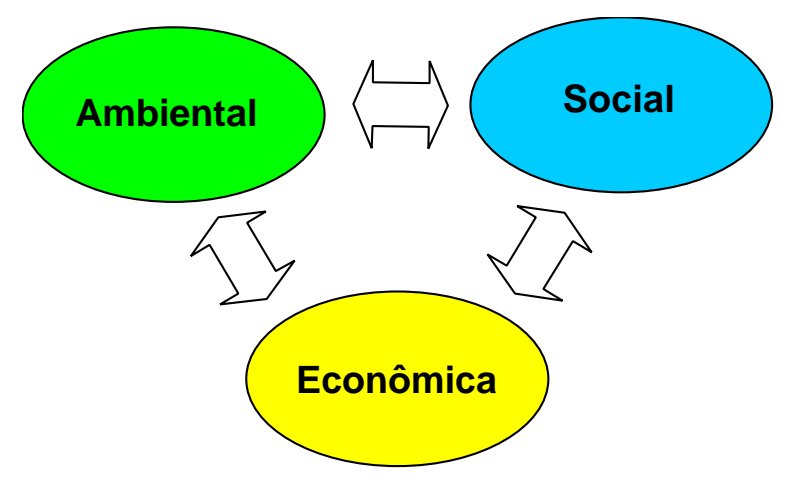

Figura 4.3: Vertentes Básicas da Sustentabilidade

No processo de identificação de necessidades sociais deve-se proceder à uma análise mais detalhada das características de índices sociais da região onde se insere o projeto.

De maneira geral, pode-se dizer que as regiões onde ainda encontramse disponíveis recursos não utilizados, são também as mais carentes de infraestrutura e as que apresentam o pior desempenho social.

A GIR deve buscar formas de associação que permitam ou facilitem a disponibilidade de estruturas ou serviços que atendam às necessidades da sociedade, especialmente de sua parcela mais carente.

Esta abordagem é parte importante do conceito de aceitação e viabilidade do empreendimento, sendo inclusive considerada na análise de projetos dessa natureza pelo Banco Mundial. 
Finalmente cabe aqui posicionar o que se considera como "socialmente necessárias", já que todos os componentes da infra-estrutura o são.

A diferenciação neste sentido merece maior atenção nos casos em que a necessidade social suplanta a econômica. Neste caso há diversos exemplos onde a implantação de determinada estrutura se "viabiliza" a despeito de inviabilidade econômica.

Isto ocorre através da atuação direta do setor público, que neste caso é quem historicamente tem definido quais são as ações necessárias ao atendimento das necessidades sociais prioritárias. Este aspecto requer uma melhor reflexão, pois o setor privado tem como meta a rentabilidade de seus investimentos e tem-se mostrado indiferente às necessidades sociais de qualquer ordem. Aos governos tem cabido tomar medidas que garantam o suprimento destas necessidades, mas estes nem sempre são sensíveis às mesmas, ou nem sempre têm demonstrado competência como investidores e administradores de projetos de infra-estrutura.

Aqui é onde ocorrem grande parte dos erros relacionados à implantação da infra-estrutura, já que se trata de resultado, além de análises técnicaseconômicas e sociais, de análise política.

Diversas causas de fracasso neste tipo de empreendimento ocorrem por adoção de políticas inadequadas, sejam tarifárias, fiscais, ou mesmo de adequação da infra-estrutura à realidade regional e temporal do local de implantação. Isto ocorre porque os governos têm atuado em áreas de competência do setor privado e não têm incentivado o interesse deste em atuar nas áreas sociais. 
Tais erros têm implicações sociais diversas e comprometem empreendimentos futuros.

Entende-se que a atuação dos governos deva ser de no máximo financiadores (facilitadores e catalisadores do empréstimo) dos projetos de infra-estrutura e de criador das condições regulatórias favoráveis à participação do setor privado neste tipo de investimento.

A GIR pode auxiliar na implementação de determinadas políticas de provisão de infra-estrutura, como já dito, auxiliando na divisão de riscos e investimentos, além de estar orientada à um melhor aproveitamento dos recursos (estratégicos, financeiros, ambientais e sociais). Poderá também analisar propostas de mudança na regulação que tornem empreendimentos sociais atrativos ao setor privado.

\subsubsection{Definição do Tipo de Atuação Privada e Pública}

A definição do tipo atuação ocorre baseada no tipo de infra-estrutura, nas condições do mercado, no nível de desenvolvimento do local, das características básicas do serviço (por exemplo se é de prestação obrigatória por parte do governo) etc. . A Tabela 4.5 anterior e a Tabela 4.9 apresentada adiante, fornecem informações que estabelecem a relação entre a infraestrutura e o melhor tipo de atuação tanto do setor privado como do setor público, segundo a visão do Banco Mundial.

As configurações de investimento (na operação e implantação) mais freqüentes atualmente são [Ref. 1]: 


\section{Opção A - Propriedade Pública e Operação Pública}

Esta é a mais comum das formas de propriedade e operação da infraestrutura e ocorre através de para-estatais, empreendimentos públicos, autoridades ou departamentos públicos, controlados por governos centrais, regionais ou locais.

Este tipo de propriedade e operação é mais bem sucedido quando operado segundo linhas comerciais, submetidas às mesmas regulações e normas do mercado comercial privado.

A competição com empresas privadas pressiona os provedores públicos à incrementarem seu desempenho, ao invés de se protegerem através de barreiras regulatórias.

A operação das entidades públicas neste ambiente proporciona a experiência necessária para que, gradualmente, se transfira a operação para o setor privado.

\section{Opção B - Propriedade Pública e Operação Privada}

Através de concessões ou leasings, o setor público pode delegar a operação das instalações de determinado componente da infra-estrutura (juntamente com os riscos comerciais), bem como a responsabilidade por novos investimentos ao setor privado. A forma de cada concessão varia com o tipo de infra-estrutura e o serviço relacionado.

\section{Opção C - Propriedade Privada e Operação Privada}

Esta é a forma de propriedade e operação mais atrativa ao investidor privado, desde que haja um potencial alto de retorno dos investimentos 
associados e riscos comerciais e políticos baixos. Os componentes da infraestrutura que têm mostrado maior potencial para este tipo de ação são as Telecomunicações, Energia, Transporte (Estradas de Ferro e Portos), desde que condicionados à uma política tarifária adequada. É menos atraente para tratamento do lixo e estradas rurais.

\section{Opção D - Provisão do Usuário e Comunidade}

Este tipo de operação e propriedade é mais adequado para serviços municipais e locais, onde a provisão através do usuário ou comunidade pode se dar em infra-estrutura de baixa escala, por exemplo: pequenas vias de ligação de vilarejos, suprimento de água e saneamento, canais de irrigação, geração isolada de energia, etc.. Tais serviços são, muitas vezes, economicamente acessíveis em muitas áreas, quando os custos recaem sobre os beneficiários. Tal modelo deve ser selecionado, projetado e implementado localmente, provendo estruturas informais até que haja expansão da rede formal de infra-estrutura.

Seguindo a organização anterior, o Banco Mundial aponta, para cada alternativa, como sendo fatores de sucesso:

\section{Opcão A (Propriedade Pública e Operação Pública)}

$\checkmark$ $\square$ Governo desempenha os papéis de proprietário, regulador e operador de maneira claramente separada;

$\checkmark$ • governo não exerce interferência em detalhes administrativos;

$\checkmark \square$ Os empreendimentos públicos estão submetidos às mesmas regras e exigências do mercado privado; 
$\checkmark \square$ Tarifas ajustadas à uma recuperação adequada do investimento e o empreendimento à um orçamento adequado;

$\checkmark$ \erviços públicos obrigatórios remunerados explicitamente por transferências públicas;

$\checkmark$ \Administradores selecionados segundo qualificação profissional e remunerados adequadamente;

$\checkmark \square$ Mecanismos apropriados de obtenção do "feed-back" dos usuários;

$\checkmark \square$ Obtenção de habilidades administrativas privadas;

$\checkmark$ Propriedade e controle compartilhados com o setor privado.

\section{Opção B (Propriedade Pública e Operação Privada)}

$\checkmark$ Base legal de contratos;

$\checkmark$ Contratos especificam claramente metas de desempenho, responsabilidades do proprietário e do operador, processos de revisões periódicas, mecanismos de solução de disputas e sanções para baixo desempenho;

$\checkmark$ Contratos firmados por um processo de seleção transparente, preferivelmente por um processo de licitação competitivo.

\section{Opcão C (Propriedade Privada e Operação Privada)}

$\checkmark$ マReestruturação apropriada e competitiva do subsetor empreendido;

$\checkmark$ Regulação para proteger os interesses públicos quando a competição é insuficiente e para encorajar o setor privado a prover estruturas relevantes;

$\checkmark$ - Barreiras a fatores que dificultem a entrada do setor privado (p. ex. restrições de acesso ao crédito); 


\section{Opcão D (Provisão do Usuário e Comunidade)}

$\checkmark \square$ Participação dos usuários ou membros da comunidade desde o início da preparação do programa, para encorajar a disposição a pagar pelo esquema;

$\checkmark$ Participação dos beneficiários garantida segundo meios organizacionais apropriados, com contribuições em dinheiro ou espécie;

$\checkmark$ $\square$ Grupo de usuários assistido por agências setoriais ou Organizações Não Governamentais, através de acesso à treinamento e assistência técnica;

$\checkmark$ Dar condições e requisitos técnicos para interconexão da estrutura local com a rede primária ou secundária de infra-estrutura, se relevante;

$\checkmark \square$ Operadores apropriadamente treinados e pagos.

A Tabela 4.9 a seguir resume as opções acima e suas respectivas funções. 
Tabela 4.9: Características do Tipo de Propriedade e Operação da InfraEstrutura

\begin{tabular}{|c|c|c|c|c|c|c|c|c|c|}
\hline \multirow[b]{4}{*}{ Função } & \multicolumn{5}{|c|}{ Opção A } & \multicolumn{2}{|c|}{ Opção B } & \multirow{4}{*}{ 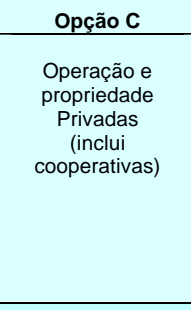 } & \multirow{4}{*}{$\begin{array}{c}\text { Opção D } \\
\\
\text { Usuário ou } \\
\text { Comunidade }\end{array}$} \\
\hline & \multirow{3}{*}{$\begin{array}{l}\text { Departamento } \\
\text { do governo }\end{array}$} & \multicolumn{4}{|c|}{ Empreendimento público } & \multirow{3}{*}{$\begin{array}{l}\text { Contrato } \\
\text { de leasing }\end{array}$} & \multirow{3}{*}{$\begin{array}{l}\text { Contrato de } \\
\text { concessão }\end{array}$} & & \\
\hline & & Tradicional & $\begin{array}{l}\text { Corporativo e } \\
\text { comercial }\end{array}$ & $\begin{array}{l}\text { Com contrato } \\
\text { de serviço }\end{array}$ & $\begin{array}{c}\text { Com contrato } \\
\text { de } \\
\text { gerenciamento }\end{array}$ & & & & \\
\hline & & & & & & & & & \\
\hline $\begin{array}{l}\text { Propriedade dos } \\
\text { bens }\end{array}$ & \multicolumn{2}{|c|}{ Público } & \multicolumn{3}{|c|}{ Público (majoritário) } & \multicolumn{2}{|c|}{ Privado (majoritário) } & $\begin{array}{c}\text { Privado } \\
\text { (majoritário) }\end{array}$ & $\begin{array}{l}\text { Privado ou } \\
\text { em comum }\end{array}$ \\
\hline $\begin{array}{l}\text { Planejamento, } \\
\text { coordenação, } \\
\text { políticas e } \\
\text { regulação } \\
\text { setorial do } \\
\text { investimento }\end{array}$ & $\begin{array}{l}\text { Interno ao } \\
\text { governo }\end{array}$ & ministério & \multicolumn{3}{|c|}{ Ministério ou autoridade pública separada } & \multicolumn{2}{|c|}{$\begin{array}{l}\text { Autoridade pública } \\
\text { negociada com o } \\
\text { operador privado }\end{array}$} & $\begin{array}{l}\text { Nenhum ou } \\
\text { autoridade pública }\end{array}$ & $\begin{array}{l}\text { Nenhum ou } \\
\text { autoridade } \\
\text { pública }\end{array}$ \\
\hline $\begin{array}{l}\text { Financiamento } \\
\text { do capital } \\
\text { (bens fixos) }\end{array}$ & $\begin{array}{l}\text { Orçamento do } \\
\text { governo }\end{array}$ & $\begin{array}{l}\text { Subsídios e } \\
\text { empréstimos } \\
\text { públicos }\end{array}$ & \multicolumn{3}{|c|}{$\begin{array}{l}\text { Principalmente financiamentos baseados em } \\
\text { marketing }\end{array}$} & Público & $\begin{array}{l}\text { Operador } \\
\text { privado }\end{array}$ & Privado & Privado \\
\hline $\begin{array}{l}\text { Financiamento } \\
\text { corrente } \\
\text { (capital de giro) } \\
\end{array}$ & $\begin{array}{l}\text { Orçamento do } \\
\text { governo }\end{array}$ & $\begin{array}{l}\text { Principalmente } \\
\text { Subsídios }\end{array}$ & \multicolumn{3}{|c|}{ Principalmente lucros internos } & \multicolumn{2}{|c|}{ Operador privado } & $\begin{array}{l}\text { Privado (governo } \\
\text { pode pagar por } \\
\text { serviços públicos } \\
\text { obrigatórios) } \\
\end{array}$ & Privado \\
\hline $\begin{array}{l}\text { Operação e } \\
\text { manutenção }\end{array}$ & Governo & \multicolumn{2}{|c|}{ Empreendimento Público } & $\begin{array}{l}\text { Operador } \\
\text { privado para } \\
\text { serviços } \\
\text { específicos } \\
\end{array}$ & $\begin{array}{l}\text { Operador } \\
\text { privado }\end{array}$ & \multicolumn{2}{|c|}{ Operador privado } & Privado & Privado \\
\hline $\begin{array}{l}\text { Coleta de } \\
\text { rendimentos } \\
\text { tarifários }\end{array}$ & Governo & $\begin{array}{l}\text { Empreendiment } \\
\text { o Público ou } \\
\text { Privado } \\
\end{array}$ & \multicolumn{3}{|c|}{ Empreendimento Público } & \multicolumn{2}{|c|}{ Operador privado } & Privado & Privado \\
\hline $\begin{array}{l}\text { Outras } \\
\text { características }\end{array}$ & \multicolumn{2}{|c|}{ Governo } & \multicolumn{2}{|c|}{ Empreendimento Público } & $\begin{array}{c}\text { Operador } \\
\text { privado }\end{array}$ & \multicolumn{2}{|c|}{ Operador privado } & Privado & Privado \\
\hline $\begin{array}{l}\text { Portador do } \\
\text { risco comercial }\end{array}$ & \multicolumn{2}{|c|}{ Governo } & \multicolumn{2}{|c|}{ Empreendimento Público } & $\begin{array}{l}\text { Principalment } \\
\text { e público }\end{array}$ & \multicolumn{2}{|c|}{ Operador privado } & Privado & Privado \\
\hline $\begin{array}{l}\text { Base da } \\
\text { compensação } \\
\text { da parte privada }\end{array}$ & \multicolumn{3}{|c|}{ Não se aplica } & $\begin{array}{c}\text { Taxa fixa } \\
\text { baseada em } \\
\text { serviços } \\
\text { rendidos } \\
\end{array}$ & $\begin{array}{l}\text { Baseado em } \\
\text { serviços e } \\
\text { resultados }\end{array}$ & \multicolumn{2}{|c|}{$\begin{array}{l}\text { Baseado em resultados, } \\
\text { rede ou taxa paga pelo } \\
\text { operador pelo uso dos } \\
\text { recursos existentes }\end{array}$} & $\begin{array}{l}\text { Determinado } \\
\text { privadamente }\end{array}$ & $\begin{array}{l}\text { Determinado } \\
\text { privadamente }\end{array}$ \\
\hline Duração típica & \multicolumn{3}{|c|}{ Sem limites } & $\begin{array}{l}\text { Menos de } 5 \\
\text { anos }\end{array}$ & $\begin{array}{c}\text { Aprox. de } 3 \text { a } \\
5 \text { anos }\end{array}$ & $\begin{array}{c}5 \text { a } 10 \\
\text { anos }\end{array}$ & 10 a 30 anos & Sem limite & Sem limite \\
\hline
\end{tabular}

Fonte: World Development Report 1994, World Bank.

\subsubsection{A Proposta da GIR}

A Gestão Integrada de Recursos busca a atuação conjunta dos entes público e privado, porém de maneira diferenciada do que tem ocorrido historicamente.

Conforme já abordado, o setor público tem-se mostrado pouco capaz de investir e administrar os componentes da infra-estrutura. 
O setor privado, por sua vez, tem-se mostrado indiferente às necessidades sociais, preocupando-se exclusivamente com o retorno do capital.

A proposta da GIR é que a análise integrada dos empreendimentos permita que cada setor participe de acordo com sua competência e a junção de ambos viabilize componentes que hoje são inviáveis às vistas do setor privado.

Ao setor público (não necessariamente governos) cabe a mudança da regulação dos setores de infra-estrutura, de forma a permitir atuações diferenciadas e criativas no sentido de se assegurar o retorno econômico das mesmas.

Dessa forma, o Estado deve atuar preferencialmente como ente regulador e, quando conveniente, através dos meios apropriados, como financiador.

Através de mecanismos regulatórios, o Estado tem meios para incentivar a participação do setor privado na infra-estrutura, e mais do que isso, deve estabelecer critérios ambientais e sociais que estejam de acordo com 0 Desenvolvimento Sustentável.

Para a sociedade caberá, além de colher os benefícios da disponibilidade de infra-estrutura, participar ativamente do processo de planejamento , sendo ouvida através de auditorias públicas, etc..

Ao setor privado fica destinada a atuação como investidor e gerenciador da infra-estrutura, que, nos moldes do mercado, deverá ser competitiva e portanto economicamente sustentável. Deverá ainda garantir a qualidade nos 
serviços prestados, a eficiência na operação e a acessibilidade por parte dos mais carentes, todos previstos na regulação.

Acredita-se que o setor institucional atuando conjuntamente com 0 empresarial devam proporcionar condições para que a infra-estrutura seja provida em maior quantidade e melhor qualidade que nos moldes atuais, onde já se evidenciaram inúmeros erros que acabaram por determinar a inacessibilidade de bens e serviços essenciais por grande parte da população em todo o mundo.

Assim sendo, segundo (Reis e Mielnick, 1999 [Ref.4], ANEXO 1) a Gestão Integrada de Recursos deverá ser estabelecida por meio de uma avaliação integrada dos aspectos institucionais e empresariais sobre as alternativas de desenvolvimento.

Segundo os autores, "do ponto de vista institucional, o enfoque se dará sobre a atuação dos agentes reguladores dos serviços de infra-estrutura, os quais, em um mercado competitivo, têm, entre outras, as funções de zelar pela preservação das regras da competição e de preservar os interesses da comunidade. O estabelecimento de projetos de interesse público, ao mesmo tempo em que resguardam os interesses dos entes participantes no projeto em si, é o tipo de ação que se visualiza no caso da Gestão Integrada de Recursos: o incentivo, a catálise, a criação de mecanismos. Sob este aspecto, o projeto deverá considerar a regulação dos serviços de infra-estrutura, com o objetivo de identificar e sugerir rumos de atuação que levem aos objetivos acima citados. 
Do ponto de vista empresarial, a abordagem considera os investidores privados, cuja principal motivação é a obtenção de lucros e demais benefícios associados aos investimentos. Considerando que o projeto vai considerar regiões que não são atrativas para cada empresa, considerada individualmente, é fundamental demonstrar a possibilidade de obtenção de ganhos por meio da formação de consórcios de empresas e de sua gestão unificada. O projeto deverá indicar os meios para realizar-se esta demonstração, assim como detalhar possíveis relações entre cada empresa e os seus investidores e a exploração das sinergias potenciais entre o conjunto das empresas envolvidas no contexto da Gestão Integrada de Recursos."

Dessa forma, a definição dos componentes da infra-estrutura nos quais se deve investir acontecerá no âmbito da análise de viabilidade, e caberá aos órgãos reguladores e ao Estado torná-los economicamente atrativos. Esta abordagem permite que o Estado evite os erros gerenciais do passado e fixese mais claramente no cumprimento de metas sociais, enquanto que a gestão empresarial procedida pelo setor privado, dentro dos moldes de mercado, deverá garantir a sustentabilidade econômica dos empreendimentos.

\subsubsection{Identificação da Sinergia (Construtiva e/ou Operativa) entre os Componentes da Infra-Estrutura}

Diversos componentes da infra-estrutura, de acordo com características próprias de construção e estruturas associadas, podem conectar-se entre si através de um único empreendimento, seja na construção ou na operação. 
A sinergia construtiva se apresenta nos casos em que a estrutura necessária para um determinado empreendimento é a mesma, ou então proporciona condições para construção de outro empreendimento. Como exemplo tem-se o caso em que, de acordo com as condições geográficas locais, barragens de hidrelétricas proporcionam a navegabilidade de rios, mediante a inclusão de eclusas no projeto.

A sinergia operativa pode se dar através de compatibilização de diferentes usos de recursos ou estruturas comuns a diferentes componentes.

Por exemplo o uso da água represada (para geração hidrelétrica) para abastecimento da população e irrigação (saneamento), controle de enchentes etc..

A sinergia operativa refere-se também à possibilidade de um mesmo empreendedor administrar e operar dois ou mais componentes da infraestrutura.

A seguir são apresentados diagramas simplificados de sinergia (construtiva e operativa) entre os componentes da infra-estrutura.

Na Figura 4.4 vê-se a sinergia entre a disponibilidade de água e energia elétrica, transporte (fluvial) e saneamento.

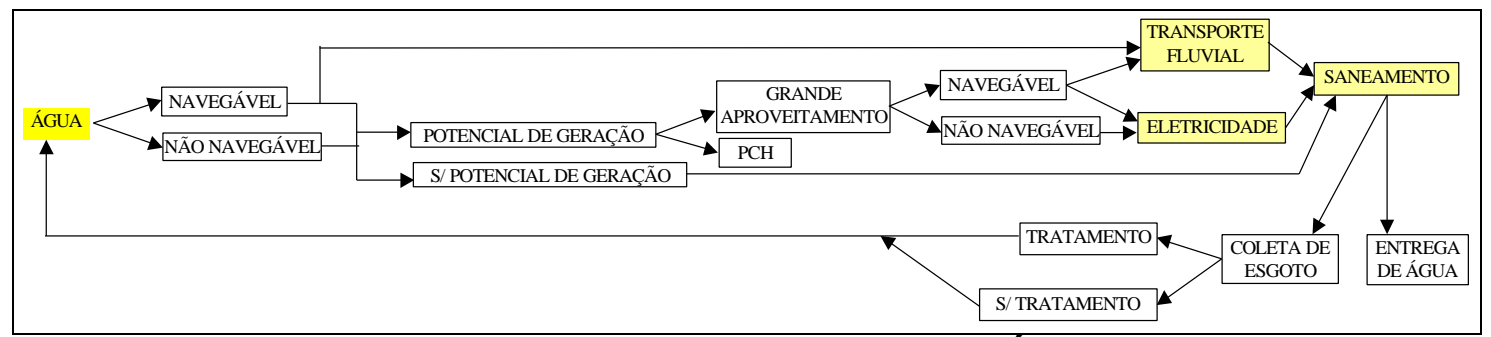

Figura 4.4: Sinergia a Partir da Água 
Nota-se a interconexão entre os múltiplos aproveitamentos e a possibilidade de um deles implicar ou não em outro.

$\checkmark \square$ água $\Rightarrow$ energia elétrica $\Rightarrow$ transporte fluvial e/ou saneamento

$\checkmark \square$ água $\Rightarrow$ transporte fluvial e/ou saneamento

$\checkmark \square$ água $\Rightarrow$ energia elétrica $\Rightarrow$ transporte fluvial + energia e/ou saneamento

$\mathrm{Na}$ Figura 4.5, referente ao recurso energia elétrica, apresenta-se um detalhamento, neste aproveitamento, do uso da água, além da opção de expansão da rede e de cogeração, cuja energia e estrutura propiciam o transporte fluvial e o saneamento.

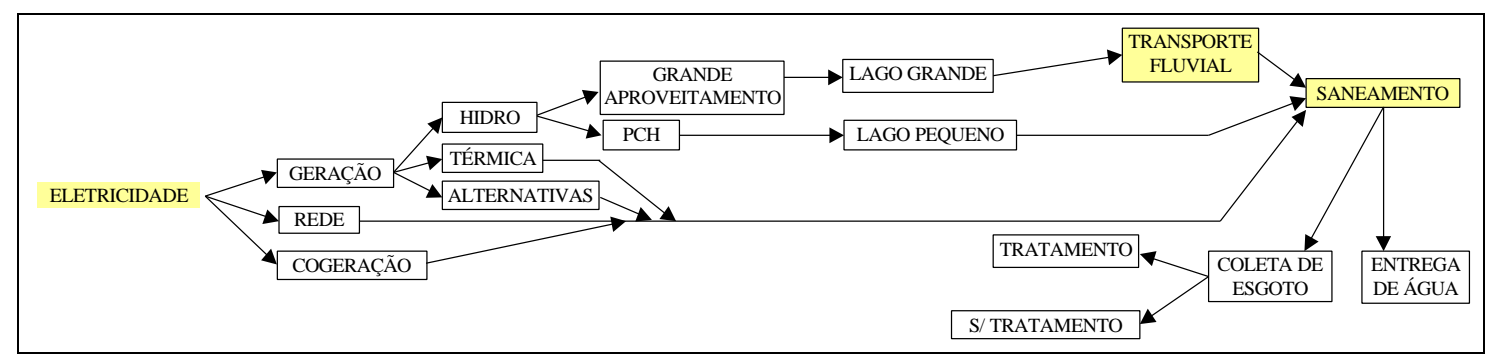

Figura 4.5: Sinergia a Partir da Eletricidade

$\mathrm{Na}$ Figura 4.6 o tratamento do lixo mostra-se associável com a eletricidade e o saneamento.

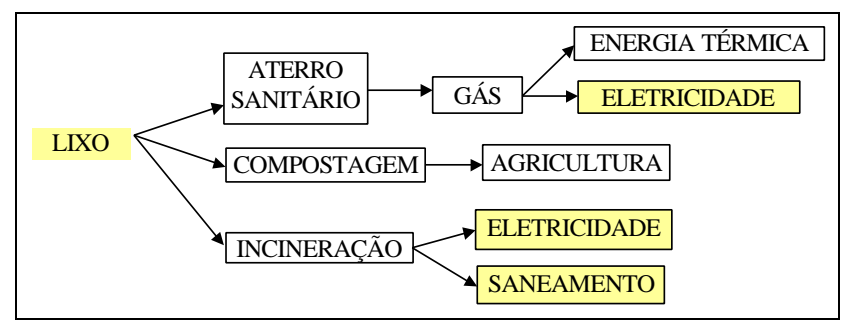

Figura 4.6: Sinergia a Partir do Tratamento do Lixo

No saneamento, a associação é óbvia, pois o próprio lixo é parte do mesmo. 
Na energia elétrica vislumbra-se a possibilidade de geração de energia termelétrica (resulta também em energia térmica - vapor) através do biogás ou da incineração, resultantes de dois processos de tratamento do lixo, o que, em si, implica em saneamento.

Na Figura 4.7 energia elétrica e telecomunicações se mesclam na possibilidade de utilização da mesma infra-estrutura necessária à distribuição de ambos (postes) ou através do uso de um mesmo meio (fibra ótica).

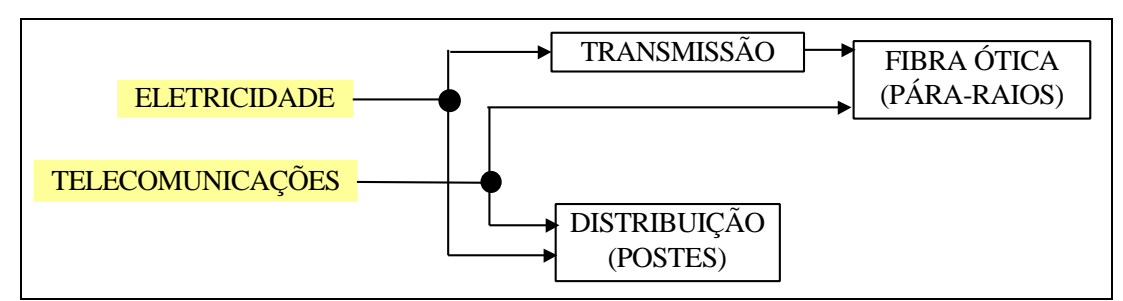

Figura 4.7: Sinergia entre Eletricidade e Telecomunicações

\subsubsection{Definição do Escopo}

A definição do escopo refere-se à etapa onde se determinam quais os componentes que se pretende associar, de acordo com análises prévias de viabilidade econômica, social e ambiental, e de acordo com a sinergia entre os componentes e objetivos que se pretendem alcançar (vide tabelas: 4.3, 4.4, 4.8).

\subsubsection{Definição do Tipo de Parceria}

A definição do tipo de parceria ocorre segundo, principalmente, os interesses econômicos e estratégicos dos investidores. 
Um conceito interessante associado ao termo parceria, é o de que nela, cada componente define as suas próprias vantagens, segundo o conceito de que todos ganham.

Dessa forma, cada participante deve ter de maneira clara, quais são as suas próprias vantagens, que no caso da GIR devem ser estabelecidas segundo as etapas anteriores.

A definição da parceria se funde também com o aspecto econômico, pois, nesta etapa, se define a forma de divisão do capital (de investimento e rendimento), conforme será visto a seguir.

Como foi dito, pode-se optar por duas formas de parcerias: uma única empresa ou empresas separadas.

A segunda opção se aplica melhor aos casos em que a sinergia entre os componentes e/ou serviços da infra-estrutura escolhidos possibilitem uma diferenciação clara em sua implantação ou operação. Dessa forma não seria necessária a criação de uma terceira empresa, pois a própria característica do empreendimento já garante a operação independente dos empreendedores.

Esta opção se caracterizaria apenas como uma aliança estratégica, sem a formação de uma estrutura própria para divisão de capital.

Se fosse necessária a criação de uma única empresa na etapa de implantação (remete-se à análise de opção por uma única empresa), a junção se daria apenas nesta etapa de investimento e cada participante deveria ter bem definida a forma de retorno lucrativo do capital investido, segundo a operação independente. 
O caso inverso, de implantação independente e operação única, é análogo.

No caso da opção por única empresa existem incontáveis maneiras de se definirem parcerias entre os participantes. A cada dia surgem inúmeras formas de associação entre empresas, decorrentes de novas necessidades, impostas pela globalização do mercado e pela crescente necessidade de se adquirir competitividade. Neste vasto campo de estudo, uma das formas de parceria entre empresas, que tem sido muito utilizada, são as chamadas Joint Ventures.

A seguir serão abordados alguns conceitos referentes a este tipo de associação. O intuito do texto é apenas o de servir como uma orientação básica para uma reflexão inicial. Segundo Lynch, o ideal seria que tais conceitos desencadeassem uma reflexão criativa que influenciasse o projeto de uma arquitetura personalizada para as necessidades específicas de cada aliança.

O texto a seguir foi extraído da [Ref. 10] , a qual é indicada para um melhor detalhamento no assunto.

\subsubsection{Estruturação de Joint Ventures}

A divisão do Capital ocorre segundo três princípios básicos: controle operacional, propriedade acionária e distribuição de compensações. 


\section{A) Controle Operacional}

"O controle operacional pode ser posto nas mãos de um proprietário minoritário; caso ele seja o mais qualificado para contribuir com recursos de gerenciamento efetivos para o empreendimento. Se um parceiro tiver apenas 20 a $25 \%$ das ações de uma Joint Venture, raramente recebe o controle operacional; ele costuma ser considerado um investidor financeiro passivo em vez de um parceiro ativo. (A exceção a esta regra ocorre quando há três ou mais parceiros).

\section{B) Propriedade Acionária}

O detentor do maior risco, ou o que mais contribui com dinheiro, freqüentemente recebe a maior participação acionária em uma Joint Venture. (Alianças estratégicas não têm interesses acionários, pois não é criada uma entidade separada). Se o proprietário da maior fatia acionária não tiver controle operacional, deve haver um processo que possibilite a esse membro "poderoso" participar da tomada de decisões juntamente com o membro "operacional" .

Em muitos acordos internacionais, os aliados decidem que não é interessante para eles ter um membro superior e um subordinado. Neste caso, uma das empresas contribui com dinheiro ou outros ativos em quantidade suficiente para criar paridade.

\section{C) Distribuição de Compensações}

O fluxo de caixa, os benefícios tributários e o ganho de capital precisam ser divididos, com a maior compensação, indo, em geral, para a parte que mais 
contribuiu para o sucesso do empreendimento. Quando se utiliza uma estrutura legal de sociedade (em vez de uma corporação), o fluxo de caixa, os benefícios tributários e o ganho de capital podem ser divididos segundo a maneira que os parceiros preferirem.

Empresas de capital aberto que precisam satisfazer as exigências de dividendos trimestrais dos acionistas, assim como empresas fracamente capitalizadas, podem querer fluxo de caixa de curto prazo e podem dar compensação a prazos mais longos para os parceiros que desejem maior ganho de capital e balanço financeiro mais sólido. Quando se utiliza a estrutura corporativa para a Joint Venture, divisões desiguais, comuns na estrutura de parceria, são pouco práticas, a menos que se usem ações preferenciais e royalties de licenciamento.

\subsubsection{Métodos de Divisão de Propriedade e Controle}

\section{A) Divisão Superior Subordinado}

Esta costuma ser uma divisão 51/49 (ou outras porcentagens que dão a uma das partes o controle claro do empreendimento, como 70/30). Nesta estrutura, a participação acionária, o controle operacional e a distribuição de compensações geralmente refletem claramente a postura maioria/minoria. Esta estrutura é utilizada com mais freqüência para empreendimentos de alto risco.

A diretoria é claramente controlada pelo parceiro superior e, portanto, é inerentemente cerimonial, quanto ao compartilhamento de informações. 


\section{Vantagens}

As vantagens deste formato estão na clareza da tomada de decisões, na capacidade de fazer ajustes rápidos e na compreensão de quem é o responsável e de quem está no controle.

\section{Desvantagens}

A parte minoritária pode não ter motivação por muito tempo, pode se sentir pressionada e pode tornar-se passiva ou descontente. Sob as piores condições, a parte majoritária pode até mesmo tirar vantagem do membro minoritário, intencionalmente ou não. O uso da estrutura superior/subordinado pode implicar na falta de uma visão unificada clara para o empreendimento, ou pode não haver um método efetivo de resolver diferenças.

\section{B) Divisão Igualitária}

Esta estrutura costuma proporcionar uma divisão 50/50 em toda a relação de trabalho e pressupõe que a contribuição, a tomada de decisões e o controle sigam a proporção 50/50. Com esta divisão nada acontece, a menos que haja consenso entre os parceiros: todos devem concordar ou, então, discutir suas diferenças até que se chegue a um acordo. A igualdade pressupõe que os parceiros sempre conseguirão resolver suas diferenças e que os gerentes operacionais tenham excelente habilidade de relações humanas para ajudar os proprietários numa efetiva tomada de decisões por consenso. Ambas as empresas são representadas igualmente na diretoria ou em comitês direcionadores; elas definem juntas a estratégia para a Joint Venture e tomam decisões operacionais em conjunto. 


\section{Vantagens}

O arranjo 50/50 ajuda a promover o engajamento ativo de ambas as partes. Este formato é mais adequado para empresas que tenham uma visão comum forte para o empreendimento, culturas corporativas semelhantes e, de preferência, uma relação pessoal amigável nos altos escalões. Usado com freqüência quando ambas as partes têm contribuições igualmente vitais de tecnologia e experiência a oferecer, este método assegura o suporte, os recursos e a colaboração de ambos os parceiros, e força o comprometimento com o sucesso do empreendimento.

\section{Desvantagens}

Infelizmente, como é visto com freqüência em parcerias, a igualdade pode ter sérios inconvenientes se não for cuidadosamente gerenciada. Pode surgir um impasse entre os parceiros quando ocorrer uma divergência. Para impedir que os conflitos surjam, os parceiros podem evitar a discussão dos problemas.

\section{C) Divisão Pela Regra da Maioria}

Esta estrutura, uma adaptação do método da igualdade, traz um terceiro componente - um acionista menor, usualmente um parceiro minoritário, que atua como um voto de desempate no caso de os de outros parceiros chegarem a um impasse. Nesta estrutura, freqüentemente disposta como 49/49/2 ou alguma variação semelhante, chega-se às decisões pela discussão de um problema até que ocorra unanimidade ou consenso. Raramente uma parceria vota de fato sobre algum assunto comercial. Gerentes hábeis sabem que o processo de boa resolução de problemas em equipe serve para construir 
consenso e comunicação, resultando em um trabalho mais forte entre os parceiros. O terceiro participante é mais do que um neutro; ele representa o "bem maior" da própria aliança.

Às vezes, a parte minoritária é assumida por um gerente do empreendimento, por um patrocinador ou por um membro da equipe de gerenciamento. Em outras circunstâncias, esta posição é ocupada por um alto executivo que se senta com a diretoria das empresas patrocinadoras. Ou ainda, esta posição pode ser preenchida por um professor universitário ou consultor profissional que devido ao conhecimento, ou conexões técnicas ou de mercado, pode ser de grande valor para que a operação seja bem sucedida.

\section{Vantagens}

A estrutura da regra da maioria possibilita que os parceiros principais permaneçam ativamente engajados no empreendimento, como no método de igualdade, sem os problemas de impasse nas decisões. O papel do parceiro minoritário envolve o incentivo de soluções criativas e novas idéias. Quando surgem conflitos, o parceiro minoritário costuma agir silenciosamente por trás dos bastidores para diagnosticar problemas e encontrar soluções elegantes que satisfaçam às condições de um duplo ganhar.

\section{Desvantagens}

A escolha certa do parceiro minoritário é crítica; pode também ser muito difícil mantê-lo suficientemente motivado, já que o mesmo pode ter muito pouco em jogo no empreendimento. Se a estrutura for multipartite (três ou mais partes), os mecanismos de controle operacional podem tornar-se complicados 
de gerenciar, a menos que sejam definidas linhas claras de autoridade e tomada de decisões.

\section{D) Empreendimentos com Múltiplas Partes}

Ter vários patrocinadores em uma Joint Venture permite que a organização e seus gerentes operem próximos às parcerias.

Há versões e variações diferentes que combinam esses métodos de divisão.

Países com restrições que impedem empresas estrangeiras de possuir $50 \%$, ou mais, de empresas domésticas têm causado a formação de numerosas Joint Ventures. Acordos internos de fluxo de caixa podem permitir que a empresa estrangeira receba honorários de gerenciamento e bônus, baseados na divisão dos lucros, além da divisão proporcional de dividendos corporativos."

\subsubsection{Técnicas Avançadas de Estruturação}

Existem diversas outras formas mais avançadas de estruturação, para as quais deve-se remeter-se à [Ref. 10]. A seguir tem-se uma destas, que poderia ser particularmente interessante para o caso da GIR.

\section{A) Joint Venture de Desmembramento}

A Joint Venture por desmembramento é uma solução para se evitarem os riscos de se iniciar uma nova empresa. Sendo assim, escolhe-se uma divisão já existente, em geral lucrativa, de uma das empresas, e vende-se 50\% dela para outro parceiro, em troca de caixa. 
O desmembramento dual, uma variante dessa abordagem, seleciona duas divisões, uma de cada parceiro, e funde-as em uma única corporação Joint Venture, conforme a figura 4.8.

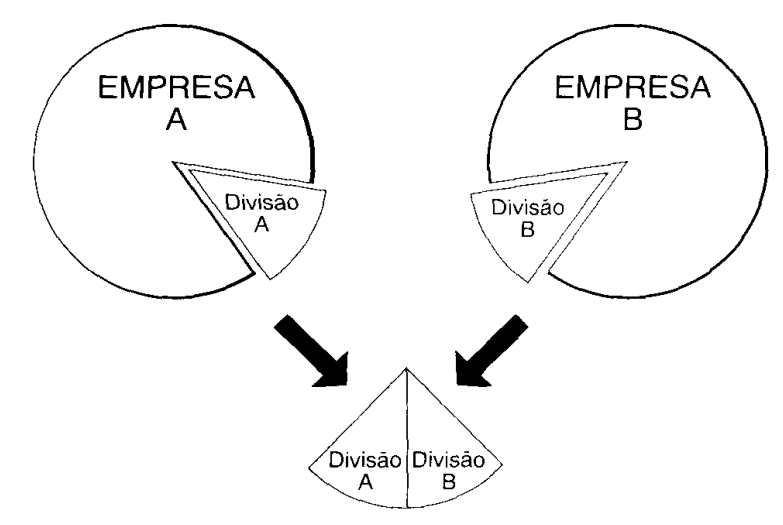

Figura 4.8: Joint Venture por Desmembramento

\subsubsection{Considerações Finais Acerca das Parcerias}

Finalmente, pode-se dizer que a definição do tipo de parceria é parte de uma análise focada em um caso de aplicação, pois envolve detalhes da infraestrutura, de cada ente interessado e até de aspectos regulatórios.

Os conceitos anteriores permitem dizer que não existem regras rígidas para a definição de parceria e que o ideal é a adequação (talvez de algum modelo anterior) à realidade pontual das empresas envolvidas, do tipo de empreendimento e das condições em que ele ocorre. 
De outro modo, aplicando-se apenas os modelos já estabelecidos, correse o risco de engessamento da parceria, o que provavelmente implicará em sua dissolução.

\subsubsection{Análise de Vantagens}

As vantagens provenientes de uma gestão integrada de recursos devem ser analisadas sob a ótica econômica, social e ambiental, nesta ordem.

Isto se deve ao fato de que, caso não haja condições para viabilidade econômica, a sustentabilidade do investimento já estará comprometida. Daí o porquê da análise econômica ser a primeira a ser satisfeita.

A análise social vem em seguida, não por ser menos importante mas porque a infra-estrutura deve atender aos interesses sociais, garantindo 0 acesso dos mais pobres, mas ao mesmo tempo garantindo o retorno do capital investido, sob pena de que, caso contrário, não haverá infra-estrutura disponível, o que é, reconhecidamente, fator de degradação social.

O meio ambiente vem em terceiro, não por grau de importância, mas por depender do sucesso dos dois anteriores. Onde não há desenvolvimento econômico e social há necessariamente a atuação humana predatória e destrutiva ao meio ambiente.

A sustentabilidade é buscada através da GIR considerando se bons os projetos que satisfaçam os três aspectos anteriores. 


\subsubsection{Análise das Vantagens Econômicas}

A análise econômica dos investimentos em infra-estrutura é um tarefa complexa e que requer um esforço a parte, que será melhor exemplificado no Capítulo 5. O detalhamento neste campo depende de análises conjunturais, decorrentes do momento em que são feitas, bem como das características e exigências particulares dos investidores.

O que se pretende aqui é a comparação dos investimentos isolados com os decorrentes da GIR.

A escolha de um componente da infra-estrutura depende de diversas análises, entre elas: de demanda, de mercado, de adequação técnica, etc.. Através delas identifica-se a infra-estrutura adequada aos interesses dos investidores.

Como seguimento a esta etapa é feita a análise econômica dos investimentos quanto à implantação e sua amortização durante a operação, de acordo com critérios de viabilidade fixados pelos investidores.

Assim sendo, de acordo com tais análises, é definida a estrutura, o capital para sua implantação, a margem de lucro esperada e consequentemente a tarifa incidente sobre o serviço.

No caso de se tratar de um componente socialmente indispensável, com conseqüente participação governamental, a participação deste pode-se dar na implantação e/ou na operação através de capital, incentivos fiscais ao setor privado, ou subsídios em tarifas, entre outros. 
Tal tipo de operação, muitas vezes, resulta em prejuízo financeiro ao Setor Público, o que pode ser minimizado com a GIR.

Uma vez que, pelo menos dois componentes da infra-estrutura ou serviços diferentes são avaliados de forma isolada, a partir da identificação da sinergia entre estes pode-se pensar na implantação da GIR.

Deve-se então proceder à uma análise de viabilidade conjunta, onde serão identificadas as vantagens e desvantagens (ambientais, econômicas e sociais) da implantação.

Para se estabelecer se há ou não vantagens econômicas, é necessário comparar-se os capitais e rendimentos (lucro ou prejuízo) das implantações e operações isoladas com os da operação e/ou implantação da GIR. Entende-se por lucro, o capital excedente após toda a remuneração do capital investido e do custo de implantação e operação, ver Figura 4.9. 


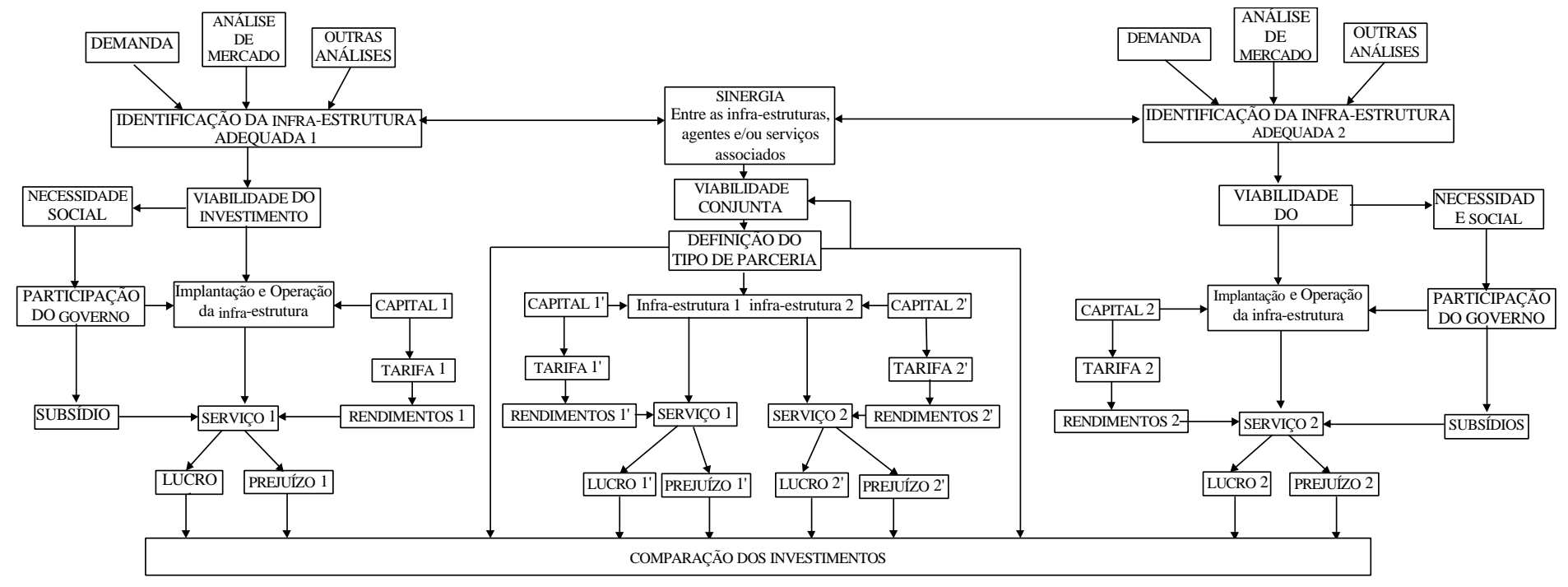

Figura 4.9 Estrutura de Comparação de Investimentos Convencionais e Segundo a GIR 
A análise econômica deve levar em consideração as possíveis combinações entre:

- O tipo de investimento - Público ou Privado;

- Quanto à implantação ou operação.

- Quanto ao tipo de parceria ou aliança.

De acordo com os critérios dos investidores, pode-se optar por implantar e/ou operar a associação sob a forma de uma única empresa ou empresas separadas.

Se for sob a forma de uma única empresa, as vantagens econômicas devem ser analisadas comparando-se os capitais e rendimentos das estruturas isoladas com o capital total e rendimento total da nova empresa (vide figura 4.10).

As formas como os capitais serão investidos ou recuperados constituem uma análise à parte, pertencente ao detalhamento do tipo de parceria, item 4.2.7.2. 


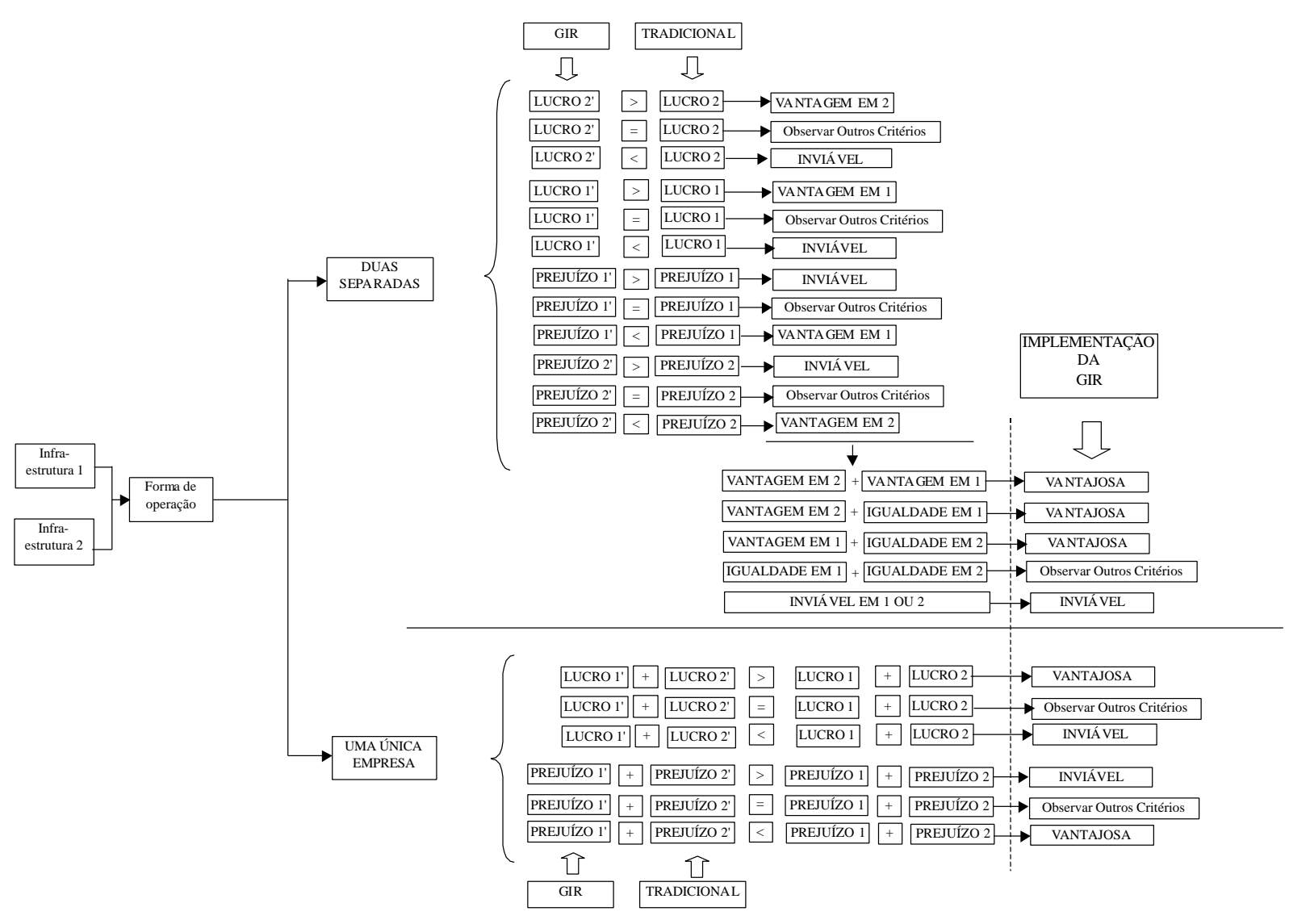

Figura 4.10:Análise de Possíveis Vantagens Econômicas 
Por outro lado, ao se optar por implantação e/ou operação através de duas empresas separadas, a análise se complica um pouco, pois poderão ocorrer diversas situações, Figura 4.10.

Neste caso a análise deverá contemplar a viabilidade em separado de cada componente da infra-estrutura e, a partir daí, analisar a viabilidade conjunta de ambas.

Basicamente a Figura 4.10 analisa as possibilidades de lucro ou prejuízo econômicos para as duas operações: empresas separadas ou única empresa.

\section{A) Única Empresa}

Neste caso a GIR foi classificada como:

Vantagem: quando apresenta lucro maior ou prejuízo menor que os da operação e/ou implantação convencionais.

Outros critérios: quando o lucro ou prejuízo empatam e então são necessárias análises de outras naturezas, por exemplo: vantagens ambientais e/ou sociais.

Inviável: quando o lucro for menor que o da operação convencional ou o prejuízo maior.

\section{B) Empresas Separadas}

Para empresas separadas, a análise é a combinação das análises anteriores.

Na Figura 4.10 encontra-se o exemplo para duas empresas separadas. 
Neste caso deve-se proceder a uma análise como a anterior para cada empresa, e a viabilidade da GIR se analisa de acordo com a combinação dos resultados.

Vantagem em 1 e Vantagem em 2, esta é a forma mais vantajosa da GIR, pois ambos os lados apresentam vantagens diretas.

Vantagem em 1 e lgualdade em 2 (ou vice-versa), ainda é vantagem, porém em um nível menor que a anterior. A aceitação da empresa em igualdade deve vir de outras análises e de possíveis acordos com a que está em vantagem.

Igualdade em 1 e 2, deve-se analogamente observar outros critérios, além do econômico.

Na parte que envolve a operação com prejuízo financeiro a análise é análoga, sendo vantajosa a possível diminuição do mesmo.

A questão do prejuízo (lucro negativo) foi tratada separadamente pois há casos em que a infra-estrutura é essencial e deve ser operada com subsídios e outros incentivos. Assim, a GIR representaria vantagem quando reduzisse 0 "prejuízo", ou seja a necessidade de subsídios e incentivos (fiscais, financeiros, etc.).

Para melhor ilustrar a motivação de se tratar o prejuízo de uma forma separada, tem-se a figura 4.11, que destaca as perdas com subsídios fiscais e ineficiência técnica, em comparação com o universo total de investimento em infra-estrutura ocorrido nos países em desenvolvimento. 


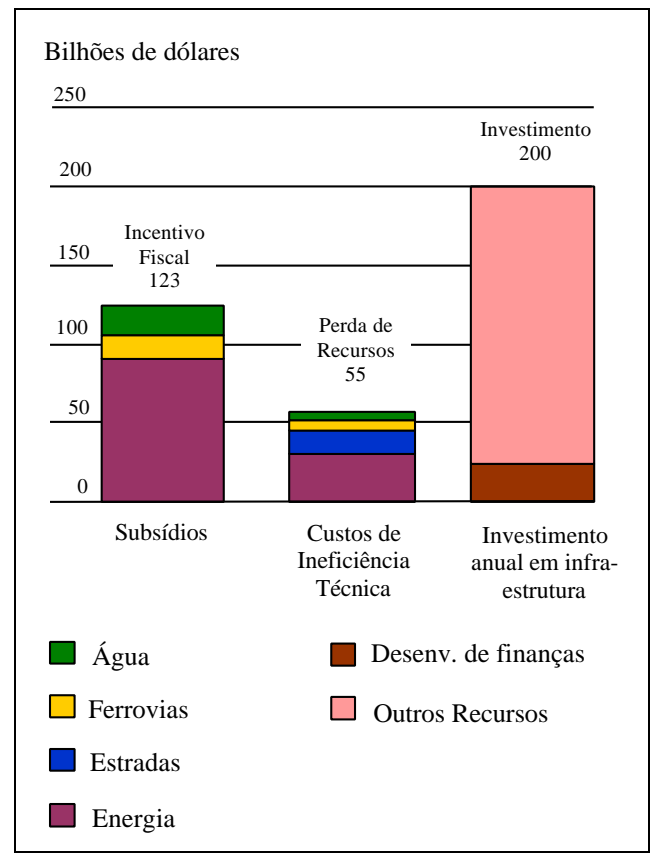

Fonte: World Development Report 1994, World Bank.

Figura 4.11: Perdas de Capital em Infra-Estrutura

Segundo relatório do Banco Mundial, somente em energia, água e ferrovias, os incentivos fiscais e subsídios representam US\$ 123 bilhões anuais, o que significa $60 \%$ do investimento anual total em infra-estrutura.

A ineficiência técnica representa outros US $\$ 55$ bilhões.

Dessa forma fica evidenciada a necessidade de se dar atenção especial à redução do "prejuízo", e o porque este fato deve ser considerado como vantagem.

\subsubsection{Análise das Vantagens Sociais}

A análise social se mescla com a econômica, na medida em que se deve sempre buscar a sustentabilidade financeira do investimento. 
Dessa maneira, o desempenho econômico dos componentes da infraestrutura tem implicação imediata sobre a população, seja pelos investimentos diretos e pelo capital movimentado, seja pelo acesso aos serviços prestados pela infra-estrutura.

Tais benefícios podem ser, de certa forma, mensurados através de índices sociais específicos, conforme será tratado adiante.

O maior benefício que pode ser identificado é justamente o acesso à infra-estrutura, principalmente pelas camadas mais carentes da sociedade.

A GIR, na medida em que facilite a provisão e o acesso à infra-estrutura, dentro dos moldes já mencionados, terá este como sendo o maior benefício social de sua implementação.

A redução de subsídios e mecanismos que oneram o Setor Público, ou ainda, o aumento na arrecadação de impostos, também serão considerados vantagem social, uma vez que a atuação do Setor Público deve ser no sentido de beneficiar a sociedade.

\subsubsection{Análise das Vantagens Ambientais}

No critério ambiental, devem ser analisadas as possibilidades de redução de impactos decorrentes de:

a) Implantação de serviços viabilizados pela GIR (por exemplo tratamento de esgotos, o que reduz impactos ambientais);

b) Redução da infra-estrutura global no atendimento dos serviços, em comparação à infra-estrutura isolada. 
Tanto num como no outro caso, o planejamento da infra-estrutura pode ser conduzido de forma a se minimizar os impactos ambientais, o que pode ser uma vantagem competitiva, pois tem como conseqüência maior facilidade na aprovação do EIA e RIMA dos projetos.

Além disso, o critério ambiental está-se tornando essencial para as empresas terem seus produtos aceitos nos mercados internacionais. Tal fato tem feito com que estas busquem fornecedores de insumos e matéria prima que também atendam à critérios ambientais mais rígidos. Dessa forma, prover serviços e infra-estrutura ambientalmente melhores torna-se um importante diferencial de competitividade.

Como conseqüência destes aspectos, o critério ambiental deve ser atendido buscando, já no planejamento integrado da infra-estrutura, formas de minimização de agressões decorrentes da implantação e operação destas. Novamente o governo deve exercer o seu papel de regulador, para garantir a preocupação dos investidores quanto a este aspecto.

\subsubsection{Aceitabilidade}

O conceito de aceitabilidade já foi apresentado no Capítulo 3, e aqui é apenas lembrado como parte integrante e fundamental do processo de desenvolvimento da Gestão Integrada de Recursos, sem o qual dificulta-se a busca desejada da suatentabilidade. 


\subsection{Metodologias, Métodos, Coleta de Dados e Informacõos}

Existem diversas metodologias e métodos de análises, tanto econômica como social e ambiental, embora as duas últimas ainda prescindam de métodos que permitam quantificá-las de modo que possam ser incluídas de maneira efetiva na análise econômica.

A seguir serão apresentados alguns exemplos de metodologias utilizadas nas avaliações econômicas, sociais e ambientais, algumas delas utilizadas no estudo de caso do capítulo 5. São apresentadas apenas a título de exemplificação, dado que existem diversos tipos de análises mais aprofundadas em todos estes aspectos, que embora devam ser consideradas em um estudo real de caso, fogem ao escopo deste trabalho.

\subsubsection{Exemplos de Metodologias de Análise Econômica}

4.3.1.1 Metodologias Para Análise Técnico-Econômica de um Projeto de uma PCH

Neste item, apresenta-se uma metodologia de análise técnicoeconômica adequada à uma avaliação preliminar expedita da viabilidade de um projeto de uma $\mathrm{PCH}$, que será utilizada no estudo de caso do capítulo 5 . Esta metodologia inclui nos cálculos de custos, os acréscimos devidos à taxas e encargos aplicáveis.

A metodologia é apresentada a seguir, com ênfase às Principais Variáveis e à descrição da metodologia, ela mesma (Reis, 1999, [Ref. 28]). 


\section{A) Principais Variáveis da Análise}

As principais variáveis da análise, consideradas na metodologia aqui descrita, são:

P : Potência instalada, em MW;

Cp : Custo unitário da Potência Instalada, em US\$/kW;

j : : taxa de recuperação anual da parcela de Investimento;

Com : Percentual da Parcela inicial de Investimento, correspondente aos custos anuais de Operação e Manutenção;

FC : Fator de Capacidade da Usina.

\section{A1) Acréscimos de Custos Devidos a Taxas e Encargos}

Na metodologia aqui descrita são considerados os acréscimos de custos devidos às seguintes taxas e encargos:

Royalties a Estados e Municípios; a Taxa de Fiscalização; os Impostos (COFINS e PIS); o Imposto de Renda e a Contribuição Social e a RGR Reserva Geral de Reversão. Os acréscimos devidos a custos de interconexão (linhas, equipamentos e componentes) e as tarifas de transporte (do Sistema de Transmissão), são também considerados na metodologia.

\section{A2) A Comercialização da Energia Elétrica}

São consideradas as duas alternativas possíveis de venda, às Concessionárias e venda ao Consumidor Final. 


\section{B) Metodologia Utilizada}

\section{B1) Custo Anual do Empreendimento}

O custo anual do empreendimento é formado por duas parcelas principais: Cinv e Co\&m.

a) Cinv é a parcela anual de recuperação do Investimento, calculada por:

\section{Cinv $=P \times C p \times 1000 \times$ FRC [ US\$ ]}

Onde:

P é a potência instalada, em MW

Cp é o custo unitário da capacidade instalada, em US\$/kW

FRC é o Fator de Recuperação do Capital, para uma série uniforme com taxa de recuperação j\% e $\mathrm{N}$ anos, dada por:

$$
F R C=\frac{i(1+i)^{N}}{(1+i)^{N}-1}
$$

A expressão acima apresenta a aproximação simplificadora de não incluir os juros durante a construção.

Esta parcela pode ter tratamento diferenciado, dependendo da forma de execução do investimento, influenciando também a escolha das principais variáveis a serem determinadas na análise econômica.

Nesta descrição metodológica, são consideradas três possibilidades:

i) Investimento efetuado no âmbito tradicional do Setor Elétrico Brasileiro. Neste caso, o período de análise (vida útil) e a taxa de retorno são 
definidos a priori e a análise se volta a determinar relações entre custos e benefícios;

ii) Investimento efetuado no contexto de um mercado aberto competitivo, com recursos próprios (de um fundo de pensão, por exemplo), sem alavancagem (parte financiada). Neste caso, o custo unitário de energia e a taxa de retorno do investimento podem ser fixadas a priori e a análise se voltará a determinar o tempo de retorno, para verificar se é atrativa com relação a outras taxas do mercado. Ou vice-versa: fixar o tempo e achar a taxa de retorno;

iii) Como o anterior, mas com alavancagem (parte do investimento financiado). Neste caso, é conveniente trabalhar com custos unitários e taxas fixas e determinar os correspondentes tempos de retorno.

No que se segue, a metodologia se dirige à avaliação completa, efetuada pelo foco de análise no âmbito tradicional do setor.

b) Co\&m é a parcela anual de custos de operação/manutenção, calculada por :

$$
\text { Co\&m }=\text { Com } \times \operatorname{Inv}=\operatorname{Com} \times \mathrm{P} \times \mathrm{Cp} \times 1000[\mathrm{US} \$ \text { ] }
$$

Onde, Com é o percentual anual de custos de operação e manutenção, relativamente aos custos de investimento.

O custo unitário da energia é calculado como se mostra em seguida:

Sendo,

$$
\text { Energia }=\mathrm{P} \times \mathrm{FC} \times 8760[\mathrm{MW} \mathrm{h}]
$$

Onde: 
8760 é o número de horas no ano,

FC é o Fator de Capacidade da usina.

O custo unitário da energia é dado por :

$\{$ Cinv + Co\&m $\} /$ Energia

B2) Acréscimos de Custo Devidos a Taxas e Encargos Incidentes, a Reserva Geral de Reversão e Outras Parcelas (Interconexão e Tarifa de Transporte de Energia)

B2.1) Taxas e Encargos

a) Royalties a Estados e Municípios: Não se aplica a PCHs.

b) Taxa de Fiscalização

Taxa $=$ Porcentagem (0,5\%) do Benefício Econômico.

Nos cálculos, considerou-se como benefício econômico o resultado das vendas brutas da energia.

c) Impostos (COFINS e PIS)

São de $2,65 \%$ no total ( $2 \%$ de COFINS e $0,65 \%$ de PIS), e incidem sobre o faturamento da empresa.

Nos cálculos também se considerou aqui o resultado das vendas brutas da energia.

d) Imposto de Renda e Contribuição Social

A serem avaliados do seguinte modo:

i) Receita Líquida e Depreciação 
Receita Líquida $=$ Receita Bruta - Custos Operacionais - Taxa de Fiscalização Impostos

ii) Lucro Tributável

Lucro Tributável $=$ Receita Líquida - Depreciação

iii) Imposto de Renda (IR)

IR $=0,15 \times$ (Lucro Tributável - Despesas Financeiras) (até $R \$ 240$ mil)

$\mathrm{IR}=0,25 \times$ (Lucro Tributável - Despesas Financeiras) (excedente a $\mathrm{R} \$ 240$ mil)

iv) Contribuição Social (CS)

CS $=0,08 \times$ Lucro Tributável

Não foram incluídos nos cálculos.

B2.2) Reserva Geral de Reversão - RGR

As empresas concessionárias de serviços públicos de energia elétrica, supridoras e supridas, devem pagar como RGR, uma quota anual de reversão de $2,5 \%$ que incide sobre seus investimentos, observado o limite de $3 \%$ da receita anual da empresa.

O decreto 2003 de 10/09/96, Art. 6, apresenta os encargos financeiros incidentes sobre autoprodutor e Produtor Independente de Energia Elétrica (PIE), não incluindo a Reserva Geral de Reversão.

\section{B2.3) Parcela de Interconexão}

Correspondente ao custo da interconexão entre a geração e o consumidor ou comprador da energia vendida. 


\section{B2.4) Tarifa de Transporte de Energia}

Correspondente à tarifas cobradas pelo sistema de Transmissão, para conexão e "pedágio". Não se aplica às PCHs até 2003.

\section{B2.5) Acréscimos de Custos Dependentes do Faturamento}

No caso de suprimento a concessionárias, a tarifa de venda da energia pode ser assumida dentro da faixa específica possível para a tarifa, levando em consideração o momento da análise e informações das próprias concessionárias.

No caso de venda para consumidor final, irá depender do fator de carga deste consumidor. Aí, a energia poderá ser vendida em dois blocos diferentes: um, com uma certa tarifa, correspondente ao contrato com o consumidor e, outro, correspondente à energia restante (se o fator de carga do consumidor for menor que $\mathrm{o}$ fator de capacidade da geração), vendida a outro comprador (concessionária, outro consumidor final, MAE, etc.)

\section{B2.5.1) Venda para Concessionária}

Os encargos e taxas podem ser calculados por :

$$
\text { Encargos: Ea (\%) x FE (US\$) / } 100+\text { Eb (US\$/MWh) x Energia }
$$

Onde:

Ea :é a soma dos encargos devidos ao COFINS, PIS e Fiscalização (3,15\%);

FE $:$ Faturamento $=$ Energia $\times$ Tarifa de Suprimento $a$ Concessionárias; 
Eb :soma taxas de interconexão (linha), tarifa de transporte.

Os encargos unitários, em US\$/MWh, são obtidos pela divisão da expressão pela quantidade de energia negociada, ou seja, pela expressão :

Encargos Unitários [US $\$ \mathrm{MWh}]=\mathrm{Ea}(\%) \times$ Tarifa de Suprimento a Concessionárias + Eb

\section{B2.5.2) Venda para Consumidor Final}

No caso da venda para consumidor final, como já apresentado, a energia pode ser dividida em duas parcelas, comercializadas de forma diferente :

Uma parcela, vendida ao consumidor com fator de carga Fcarga, com tarifa nível A2, dada por

Energia Consumidor = Energia $\times$ Fcarga;

e a outra parcela, vendida na forma de energia sem demanda, dada por:

Energia sem Demanda = Energia $\times(1-$ Fcarga $)$.

Nos dois casos Energia é o valor calculado pela equação (4.4).

Nas equações para cálculos dos encargos e taxas, apresentadas anteriormente, a variável FE passa a ter duas parcelas.

No caso de venda final ao consumidor, os encargos unitários são dados por :

Encargos Unitários [US\$/MWh] $=\mathrm{Ea}(\%) \times[$ Tarifa Média Ponderada $]+\mathrm{Eb}$ 
Sendo:

Tarifa Média Ponderada $=$

Fcarga x Tarifa Venda Consumidor Final + (1 - Fcarga) $x$ Tarifa sem Demanda.

\subsubsection{Metodologias Para Análise Técnico-Econômica da Produção Agrícola da Pupunha}

Analogamente ao caso da PCH, a pupunha, utilizada no Capítulo 5, será analisada segundo o método do Fator de Retorno do Capital.

A diferença básica é que, na pupunha, foi considerada a cobrança de juros durante a carência do empréstimo.

Assim, o valor total do empréstimo é corrigido de acordo com o número de meses de carência e, a partir da primeira colheita, os pagamentos (juros + amortização do capital) serão saldados anualmente segundo uma Parcela de Investimento, igualmente ao caso da $\mathrm{PCH}$.

A partir daí as análises se igualam, e o resultado é uma tabela contendo os custos e a lucratividade do cultivo da pupunha.

\subsubsection{Exemplos de Metodologias para Análise Social de Projetos.}

Existem diversas formas de se avaliar os impactos sociais decorrentes de um projeto. 
A forma mais comumente utilizada é avaliação através de indicadores, tais como Produto Interno Bruto - PIB per capita, Produto Nacional Bruto - PNB per capita, Índice de Desenvolvimento Humano - IDH, taxa de mortalidade infantil, taxa de instrução da população etc..

Existem também outros métodos mais completos, tais como a Matriz de Leontief, ou a Avaliação de Custos Completos, descrita no item 4.4.

A seguir tem-se a descrição sucinta de alguns destes índices e métodos.

\subsubsection{Indicadores}

Um dos indicadores mais utilizados para medição do desenvolvimento é o PNB per capita, ou ainda o PIB per capita.

O PIB (Produto Interno Bruto) refere-se à produção total de bens e serviços produzidos por uma economia [Ref. 9].

O PNB (Produto Nacional Bruto) é o PIB mais a renda líquida recebida do exterior, subtraindo-se pagamentos de mesma natureza efetuado ao exterior.

O PNB per capita é o valor médio dos bens e serviços, i.e., renda, disponível para cada pessoa de um país [Ref. 9].

Como se trata de um valor médio, acaba por encobrir distorções consideráveis de renda, presentes principalmente em países como o Brasil. Ainda assim, tais índices têm sido bastante empregados como indicadores do desempenho social de países e regiões. 
Outro índice utilizado é o IDH (Índice de Desenvolvimento Humano), que procura corrigir os problemas de índices como o PNB per capita.

O IDH incorpora outros índices, tais como a expectativa de vida e o grau de instrução da população e é composto da seguinte forma [Ref. 9]:

- Longevidade - medida pela expectativa de vida;

- Instrução - medida por uma combinação da alfabetização adulta (peso de dois terços) e anos médios de escolaridade (peso de um terço);

- Padrão de Vida - medido pelo poder de compra, baseado no PIB real per capita, ajustado para o custo de vida local.

O índice é composto pela média dos valores atribuídos à cada um dos componentes anteriores, segundo uma escala de 0 a 1.

Um aspecto interessante é o relacionamento que $\mathrm{o} I \mathrm{IDH}$ tem com a disponibilidade de energia. A partir de um TEP/capita/ano, o valor do IDH é 0,8 e praticamente constante para os países. Assim sendo, o valor energético per capita de 1 TEP/ano parece ser a energia necessária mínima para garantir um IDH aceitável [Ref. 9].

\subsubsection{Método da Matriz de Leontief}

O método da matriz de Leontief também pode ser utilizado para avaliação dos impactos sociais de um projeto.

Neste método, é construída uma matriz que relaciona o setor analisado com os demais setores da economia, de onde se determina o efeito 
multiplicador que cada unidade monetária investida neste setor tem sobre os demais.

Esta análise permite também a determinação do número de empregos gerados a partir deste incremento de unidade monetária neste setor e de seu efeito multiplicador nos demais.

O método é baseado na demanda direta que uma dado setor exerce sobre si mesmo e sobre os demais setores produtivos.

Para melhor esclarecer o método, são apresentadas a seguir exemplos de algumas tabelas, retiradas da [Ref. 20].

Inicialmente deve-se construir a tabela de Coeficientes Intersetoriais, presente nos estudos de relações Intersetoriais do IBGE. Esta tabela relaciona o efeito da demanda entre os setores produtivos.

Tabela 4.10: Coeficientes Técnicos Intersetoriais - IBGE 1995

\begin{tabular}{|l|c|c|c|c|c|c|c|}
\hline \multicolumn{1}{|c|}{ SETOR } & \multirow{2}{*}{ AGROPECUÁRIA } & SIDERURGIA & CONST. CIVIL & COMÉRCIO & TRANSP. & COMUNIC. & INSTITUIÇÕES \\
\hline AGROPEC. & 0,146 & 0,034 & 0,000 & 0,000 & 0,000 & 0,000 & 0,000 \\
\hline SIDERURGIA & 0,000 & 0,391 & 0,006 & 0,000 & 0,000 & 0,000 & 0,000 \\
\hline PAPEL E GRÁFICA & 0,000 & 0,003 & 0,001 & 0,016 & 0,003 & 0,004 & 0,005 \\
\hline CONST. CIVIL & 0,000 & 0,001 & 0,038 & 0,003 & 0,005 & 0,005 & 0,000 \\
\hline COMÉRCIO & 0,022 & 0,020 & 0,036 & 0,021 & 0,037 & 0,007 & 0,008 \\
\hline TRANSPORTES & 0,017 & 0,030 & 0,011 & 0,036 & 0,056 & 0,014 & 0,011 \\
\hline COMUNIC.AÇÕES & 0,000 & 0,003 & 0,001 & 0,010 & 0,007 & 0,001 & 0,014 \\
\hline INST. FINANC. & 0,004 & 0,013 & 0,003 & 0,018 & 0,019 & 0,011 & 0,069 \\
\hline A. PÚBLICA & 0,005 & 0,002 & 0,002 & 0,011 & 0,005 & 0,007 & 0,015 \\
\hline
\end{tabular}

Fonte: Pieroni, 1999. [Ref. 20]

Matriz incompleta, apenas para exemplificação.

A Matriz de Leontief (vide Tabela 4.11), também denominada matriz dos coeficientes de efeitos diretos e indiretos, é calculada a partir da inversão da 
Matriz dos Coeficientes Técnicos Intersetoriais (vide Tabela 4.10, que na realidade é uma matriz quadrada, reduzida aqui por se tratar de um exemplo).

Os coeficientes desta matriz indicam o aumento (de unidade monetária) necessário de produção dos setores indicados nas linhas para atender a um aumento na demanda final dos setores indicados nas colunas [Ref. 20].

Tabela 4.11 Matriz de Leontief

\begin{tabular}{|c|c|c|c|c|c|c|c|c|}
\hline Setor & \multirow[t]{2}{*}{ AGROPECUÁRIA } & \multirow[t]{2}{*}{ SIDERURGIA } & \multirow{2}{*}{$\begin{array}{l}\text { PAPEL E } \\
\text { GRÁFICA }\end{array}$} & \multirow{2}{*}{$\begin{array}{c}\text { INDÚSTRIA } \\
\text { TÊXTIL }\end{array}$} & \multirow{2}{*}{$\begin{array}{l}\text { CONST. } \\
\text { CIVIL }\end{array}$} & \multirow[t]{2}{*}{ COMÉRCIO } & \multirow[t]{2}{*}{ TRANSP. } & \multirow{2}{*}{$\begin{array}{l}\text { INSTITUIÇÕES } \\
\text { FINANCEIRAS }\end{array}$} \\
\hline SETOR & & & & & & & & \\
\hline AGROPEC. & 1,195 & 0,077 & 0,058 & 0,096 & 0,011 & 0,011 & 0,009 & 0,004 \\
\hline SIDERURGIA & 0,006 & 1,675 & 0,014 & 0,012 & 0,042 & 0,005 & 0,015 & 0,002 \\
\hline IND. DE PAPEL & 0,008 & 0,016 & 1,328 & 0,020 & 0,010 & 0,030 & 0,013 & 0,016 \\
\hline ITÊXTIL & 0,005 & 0,005 & 0,008 & 1,516 & 0,003 & 0,003 & 0,012 & 0,002 \\
\hline CON. CIVIL & 0,001 & 0,005 & 0,007 & 0,004 & 1,041 & 0,006 & 0,008 & 0,002 \\
\hline COMÉRCIO & 0,038 & 0,054 & 0,093 & 0,080 & 0,053 & 1,033 & 0,053 & 0,016 \\
\hline TRANSPORTE & 0,032 & 0,070 & 0,040 & 0,036 & 0,027 & 0,049 & 1,072 & 0,016 \\
\hline COMUNICA & 0,003 & 0,010 & 0,017 & 0,008 & 0,004 & 0,013 & 0,010 & 0,017 \\
\hline INST. FINANC. & 0,011 & 0,035 & 0,025 & 0,023 & 0,010 & 0,026 & 0,028 & 1,077 \\
\hline
\end{tabular}

Fonte: Pieroni, 1999 [Ref. 20]

Matriz incompleta, apenas para exemplificação.

Além destas, pode-se construir a Matriz de Coeficientes Técnicos de Geração de Empregos (vide Tabela 4.12), que relaciona a absorção de empregos diretos e indiretos por unidade de investimento efetuada nos ramos de atividade produtiva.

As atividades profissionais, na versão de 1980 do IBGE, são divididas em 2 categorias: empregos diretos e empregos diretos mais os indiretos. Essas duas categorias são apresentadas segundo quatro considerações diferentes: total de empregos gerados, total de empregos desconsiderando os sem remuneração, pessoal ocupado na produção (POP) e POP mais trabalhadores 
autônomos. Nas linhas são apresentados os setores produtivos segundo o nível de agregação considerada na Matriz de Insumo-Produto.

Tabela 4.12: Emprego e Coeficiente de Geração de Empregos - IBGE 1980

\begin{tabular}{|l|c|c|c|c|c|c|c|c|}
\hline & \multicolumn{3}{|c|}{ DIRETO } & \multicolumn{3}{c|}{ DIRETO + INDIRETO } \\
\hline ATIVIDADE & TOTAL & $\begin{array}{c}\text { TOTAL EXCETO } \\
\text { S/ } \\
\text { REMUNERAÇÃO }\end{array}$ & POP & $\begin{array}{c}\text { POP+ } \\
\text { AUTÔNOMOS }\end{array}$ & TOTAL & $\begin{array}{c}\text { TOTAL EXCETO S/ } \\
\text { REMUNERAÇÃO }\end{array}$ & POP & $\begin{array}{c}\text { POP+ } \\
\text { AUTONNOMOS }\end{array}$ \\
\hline AGROPECUÁRIA & 7,92 & 3,05 & 0,02 & 2,98 & 9,76 & 3,96 & 0,19 & 3,77 \\
\hline SIDERURGIA & 0,21 & 0,21 & 0,12 & 0,13 & 1,78 & 1,41 & 0,69 & 1,02 \\
\hline $\begin{array}{l}\text { IND.DE PAPEL E } \\
\text { GRÁFICA }\end{array}$ & 0,55 & 0,55 & 0,39 & 0,40 & 1,76 & 1,54 & 0,88 & 1,13 \\
\hline IND. TÊXTIL & 0,82 & 0,81 & 0,67 & 0,70 & 2,36 & 1,99 & 1,32 & 1,65 \\
\hline CONST. CIVIL & 1,65 & 1,64 & 0,59 & 1,14 & 2,86 & 2,71 & 1,16 & 1,94 \\
\hline COMÉRCIO & 1,82 & 1,59 & 0,64 & 1,19 & 2,30 & 2.00 & 0,83 & 1,48 \\
\hline TRANSPORTE & 1,93 & 1,93 & 0,81 & 1,09 & 2,57 & 2,50 & 1,06 & 1,49 \\
\hline COMUNIC. & 1,16 & 1,16 & 0,86 & 0,86 & 1,66 & 1,62 & 1,09 & 1,19 \\
\hline $\begin{array}{l}\text { INSTITUIÇÕES } \\
\text { FINANCEIRAS }\end{array}$ & 0,58 & 0,58 & 0,53 & 0,53 & 0.92 & 0,90 & 0,68 & 0,75 \\
\hline
\end{tabular}

Fonte: Pieroni, 1999. [Ref. 20].

Uma crítica que tem sido feita à este método é no que se refere à utilização de coeficientes fixos e lineares para a demanda dos setores, mas, para períodos curtos de análises, de até um ano, sua utilidade se mantém.

\subsubsection{Exemplos de Metodologias para Análise Ambiental de Projetos}

Das três análises, a ambiental é a que apresenta o maior grau de dificuldade, seja pelo alto grau de subjetividade que envolve, seja pela dificuldade de valoração dos impactos ambientais.

Tentando contornar estas dificuldades, têm surgido diversos métodos de avaliação de desempenho ambiental de alternativas, das quais algumas serão descritas sucintamente a seguir. 


\subsubsection{Estudo de Impacto Ambiental - EIA}

No processo de desenvolvimento de um plano ambiental é necessário que se avalie o impacto das ações propostas no plano dos meios físico, biológico e sócio-econômico. Um estudo deste tipo é dito Estudo de Impacto Ambiental - EIA [Ref. 5].

Segundo (Carvalho, 1997, [Ref. 21]), "O EIA pode ser descrito como um processo de identificação de prováveis conseqüências para meio biogeofísico e para saúde e bem estar do homem devido à implementação de alguma atividade, ou, numa ótica mais ampla, envolvendo todos os efeitos sócioeconômicos.

Sob o ponto de vista técnico, o EIA pode ser entendido como um processo de gerenciamento de dados. Ele possui três componentes. Primeiramente, a informação necessária apropriada para uma particular decisão a ser tomada, deve ser identificada, e, se possível, coletada. Secundariamente, mudanças nos parâmetros ambientais resultantes de implementação, devem ser determinadas e comparadas com a situação provável originada sem a proposição. Finalmente, mudança atual deve ser registrada e analisada.

$\mathrm{Na}$ verdade, a maior contribuição do EIA para o gerenciamento ambiental é a redução de impactos adversos antes do projeto atingir a sua fase de sancionamento."

De acordo com (Munn (1975) in [Ref. 5]) uma avaliação de impacto ambiental deve: 
a) descrever a ação proposta bem como alternativas à elas;

b) prever a natureza e a magnitude dos efeitos ambientais;

c) identificar as preocupações humanas relevantes;

d) listar os indicadores de impacto a serem utilizados e para cada um definir sua magnitude. Para o conjunto de impactos, os pesos de cada indicador obtidos do tomador de decisão ou das metas nacionais.

e) a partir dos valores previstos em (b) determinar os valores de cada indicador de impacto e o impacto ambiental total.

No Brasil, a avaliação de impactos ambientais está legalmente consubstanciada em dois instrumentos de gestão do ambiente, denominados EIA (Estudos de Impacto Ambiental) e RIMA (Relatório de Impacto Ambiental), cujas respectivas definições são dadas a seguir.

\section{E.I.A -Estudo de Impacto Ambiental - (CONAMA, 1986)}

Relatório técnico, elaborado por equipe multidisciplinar, independente do empreendedor, profissional e tecnicamente habilitada para analisar os aspectos físico, biológico e sócio-econômico do ambiente, que, além de atender aos princípios e objetivos da Lei da Política Nacional do Meio Ambiente, deve obedecer às seguintes diretrizes gerais:

I. Contemplar todas as alternativas tecnológicas e de localização do projeto, confrontando-as com a hipótese de não execução do projeto;

II. Identificar e avaliar sistematicamente os impactos ambientais gerados nas fases de implantação e de operação; 
III. Definir os limites da área geográfica a ser direta ou indiretamente afetada pelos impactos, denominada área de influência do projeto, considerando, em todos os casos, a bacia hidrográfica na qual se localiza;

IV. Considerar os planos e programas governamentais, propostos e em implantação, na área de influência do projeto e sua compatibilidade (inclusive diretrizes específicas e peculiares ao projeto, adicionais, fixadas pelo órgão estadual ou, quando couber, municipal competente). Como conteúdo mínimo o EIA deverá apresentar:

I. Informações gerais do empreendedor (identificação, histórico, localização, etc.);

II. Caracterização do empreendimento (objetivos, porte, etapas de implantação, etc.);

III. Área de influência do empreendimento;

IV. Diagnóstico ambiental da área de influência - descrição e análise dos recursos ambientais e suas interações, tal como existentes, nos meios físico, biológico e sócio-econômico.

V. Análise dos impactos e empreendimentos e de suas alternativas identificação, previsão de magnitude e importância (permanência, reversibilidade, cumulatividade, sinergismo, distribuição social, dos custos e benefícios, etc.) dos impactos relevantes prováveis.

VI. Definição de Medidas Mitigadoras dos impactos negativos. 
VII. Definição de Programa de Acompanhamento e Monitoramento dos impactos e das medidas mitigadoras através dos fatores e parâmetros ambientais de interesse.

RIMA - Relatório De Impacto Ambiental - (CONAMA, 1986)

Relatório resumo dos estudos do EIA, em linguagem objetiva e acessível para não-técnicos, contendo no mínimo:

I. objetivos e justificativas do empreendimento;

II. descrição do empreendimento e das alternativas locacionais e tecnológicas existentes (área de influência, matéria prima, energia, processo, efluentes, resíduos, etc.);

III. síntese dos resultados do diagnóstico ambiental;

IV. descrição dos impactos prováveis;

V. caracterização da qualidade ambiental futura;

VI. efeitos esperados das medidas mitigadoras;

VII. programa de acompanhamento e monitoramento;

VIII. conclusões e recomendações da alternativa mais favorável.

\subsubsection{Método da Matriz de Leontief}

Analogamente ao método descrito no item 4.3.2.2, a matriz de Leontief pode ser utilizada para quantificação de impactos ambientais secundários produzidos pela atividade de determinado setor, (James, 1994, [Ref. 19]). 
Para isso, ao invés do efeito multiplicador econômico seria considerado o efeito multiplicador ambiental, representado por coeficientes relacionados ao meio ambiente, tais como emissões, cobertura vegetal etc..

Sendo assim, ao se investir em um projeto de um determinado setor é possível estimar-se os efeitos ambientais globais decorrentes do efeito multiplicador deste setor sobre os demais.

Estes foram apenas alguns exemplos dos cada vez mais numerosos e sofisticados métodos de avaliação ambiental, sendo que o mais importante no tocante à GIR é consideração do meio ambiente como elemento fundamental para avaliação do projetos.

\subsubsection{Coleta de Dados e Informações}

Para elaboração dos estudos de qualquer natureza (econômica, social ou ambiental) uma etapa crítica é obtenção de dados e informações confiáveis.

Tanto a padronização dos dados como sua confiabilidade são afetados por diversos fatores. Segundo relatório do Banco Mundial [Ref. 1], os métodos estatísticos, a cobertura, as práticas e definições relativas à coleta de dados variam localmente, e a mudança de região ou período de tempo dos dados envolvem problemas complexos de difícil solução.

Daí tem-se que os dados normalmente disponíveis, devem ser usados mais para avaliação de tendências que para quantificação precisa.

A obtenção de dados acurados de uma região e suas características envolve grandes período de tempo e volume de capital para ser realizada. 
Mesmo assim, os dados conseguidos através dos meios mais comuns, como os censos populacionais, estudos realizados por órgãos governamentais, podem ser usados com relativa margem de confiabilidade no processo de avaliação de alternativas.

No estudo de caso do capítulo 5, são utilizados dados referentes à região do Médio Paranapanema, que foram levantados através de um estudo realizado pelo Departamento de Energia e Automação Elétricas da Universidade de São Paulo (Udaeta, 1999, [Ref. 22]).

\subsection{Avaliação de Alternativas}

$\mathrm{Na}$ avaliação de alternativas segundo a GIR, de maneira genérica, podese considerar como a melhor alternativa aquela que:

Apresente a maior autonomia financeira, em relação ao capital público. De preferencia seja totalmente privada e autônoma (sem subsídios);

Garanta o acesso aos serviços por todas as classes sociais;

- Remunere o capital investido de forma atrativa e sustentável à ampliação dos serviços por parte do setor privado;

Apresente uma estrutura administrativa enxuta e níveis de eficiência elevados;

Esteja voltada à preservação do meio ambiente. 
Estes conceitos são genéricos e se aplicam à quaisquer componentes da infra-estrutura.

Obviamente a análise detalhada de cada um é dependente do tipo de componente e suas características, bem como dos particularidades da região de implantação e das soluções propostas.

A abrangência e multidisciplinariedade neste campo não permitem que se defina parâmetros rígidos de análise, ficando esta tarefa relegada ao momento de uma análise pontual de cada caso estudado.

Para tanto, nos estudos pontuais, existem diversos métodos mais abrangentes e flexíveis que permitem uma avaliação de alternativas.

Como exemplo de um método abrangente, que considera paralelamente os aspectos econômico, social e ambiental pode-se citar o método da Avaliação de Custos Completos, que será descrito sucintamente a seguir.

\subsubsection{Método da Avaliação dos Custos Completos}

A Avaliação dos Custos Completos permite que se avalie diferentes alternativas considerando-se com pesos iguais os critérios Econômico, Social e Ambiental.

Este método será descrito de maneira resumida a seguir e para um maior aprofundamento remete-se à [Ref. 21].

O método descrito a seguir foi inicialmente desenvolvido para avaliação de recursos energéticos, mas pode-se extendê-lo a outros recursos. Para que 
se dê início ao processo de avaliação, é feita uma triagem inicial dos recursos considerados, descrita a seguir, segundo extrato da [Ref. 21].

\subsubsection{Triagem Inicial dos Recursos}

\section{A) Definição}

"Por Triagem Inicial dos recursos energéticos, entende-se como sendo a seleção daqueles recursos que sejam mais factíveis e que condizem mais com a realidade da região em foco. Esta é a primeira etapa do processo de avaliação e seleção dos recursos energéticos.

\section{B) Etapas}

A Triagem Inicial pode ser dividida nas seguintes etapas:

1. Definir as opções de suprimento de energia ou os chamados recursos energéticos;

2. Definir os "Elementos de Triagem";

3. Selecionar os Atributos e os respectivos Indicadores;

4. Montar as "Matrizes de Avaliação" , sendo uma matriz para cada atributo contendo os respectivos indicadores;

5. Realizar a avaliação através das matrizes, segundo a ordem, a saber: Avaliação por Efeitos, Avaliação por Pontuação e Avaliação por Conceituação.

6. Selecionar as opções com melhor conceituação, discutir e interpretar os resultados quanto à coerência e factibilidade. 


\section{C) Critérios Adotados}

Os critérios usados para a triagem ou o que é denominado de "elementos de triagem", são os seguintes:

> Tempo de Estudo

> Características da Região : São as características geográficas, econômicas, populacionais, sociais, de infra-estrutura, políticas, etc. .

Cada recurso deve ser avaliado segundo determinados atributos, sendo que cada atributo possui diversos indicadores que procuram contemplar os aspectos mais importantes a ele relacionado. Abaixo são apresentados os atributos e seus indicadores:

a.) Atributo Ambiental: Aspectos minerais, Água, Cobertura vegetal, Fauna terrestre, Fauna aquática, Uso do solo, Emissões aéreas;

b.) Atributo Sócio-Cultural: Aspectos rurais, Aspectos urbanos, Infraestrutura local, Usos múltiplos, Criação de empregos, Riscos à saúde humana, Migração;

c.) Atributo Econômico: Tempo de implantação, Disponibilidade de recursos na região, Custos de instalação e O\&M, Rendimento e eficiência, Facilidade de implantação na região.

\subsubsection{Metodologia de Avaliação}

A avaliação dos recursos é feita através de matrizes, onde, para cada atributo, tem-se uma matriz correspondente, sendo que todos os atributos têm 
pesos iguais para fins de avaliação. A avaliação deve seguir os seguintes passos:

Passo 1: Refere-se à "Avaliação por Efeitos" onde se busca avaliar os recursos qualitativamente utilizando a seguinte escala: Fortemente positivo, Positivo, Moderado, Negativo e Fortemente negativo;

> Passo 2: Corresponde à "Avaliação por Pontuação" onde se obtém uma pontuação a partir da avaliação anterior;

Passo 3: A partir da pontuação obtida chega-se, por fim, a uma "Avaliação por Conceituação" onde os recursos são avaliados para cada atributo segundo os seguintes conceitos: Máximo, Alto, Médio, Baixo e Mínimo;

> Passo 4: Por fim, de posse das avaliações intermediárias chega-se a uma avaliação final, obtendo-se um score e consequentemente uma conceituação final para cada recurso.

\subsubsection{Seleção dos Recursos}

A seleção dos recursos é feita com base nos resultados finais das matrizes de avaliação, onde selecionam-se os recursos que obtiverem maior conceituação, verificando-se a consistência dos resultados.

Por fim, vale ressaltar que as avaliações obtidas são comparativas, de forma que os recursos selecionados são os que obtiverem as maiores conceituações em relação aos outros recursos considerados, particularmente 
aplicados para a região em estudo, tendo em vista a consideração dos elementos de triagem expostos.

\subsubsection{Avaliação dos Custos Completos}

\section{A) Conceitos Importantes}

Para que se possa definir o que é a Avaliação dos Custos Completos (ACC) é preciso explicitar alguns conceitos a ela relacionados:

a) Externalidades: Em relação aos recursos energéticos, entende-se por externalidades ou impactos externos, como sendo os impactos negativos derivados de uma tecnologia de geração de energia cujos custos não são incorporados ao preço da eletricidade e, consequentemente, não são repassados aos consumidores, sendo arcados por uma terceira parte ou pela sociedade como um todo.

b) Custos Internos: São aqueles custos explicitamente avaliados numa transação de mercado. Eles são os recursos pagos diretamente pela empresa para atingir um objetivo específico como é o caso de adquirir combustível, custear operações, manutenção e atividades administrativas.

c) Custos Externos: São custos não diretamente sofridos pelos usuários do recurso mas impostos aos outros pelas conseqüências da degradação ambiental. Pode-se definir ainda os custos externos como o valor monetário de uma externalidade. 


\section{B) Definição de Análise dos Custos Completos}

É um meio pelo qual considerações ambientais podem ser integradas nas decisões de um determinado negócio. Ela é uma ferramenta que incorpora custos ambientais e custos internos com dados de impactos externos e custos/benefícios de atividades sobre o meio-ambiente e na saúde humana.

Nos casos onde os impactos não podem ser monetarizados, são usadas avaliações qualitativas.

Trata-se então de uma ferramenta para auxiliar as tomadas de decisão.

A abordagem da ACC consiste em internalizar ou incorporar os custos externos buscando também definir e alocar melhor os custos internos.

Devem-se determinar os custos internos associados com os recursos considerados e avaliar qualitativamente os custos externos uma vez que para monetarizá-los seria necessário um estudo mais amplo.

\section{B1) Custos Internos}

Os custos internos podem ser calculados segundo os métodos apresentados no item 4.3.1.

\section{B2) Custos Externos}

Abaixo é descrita a metodologia utilizada para se considerar esses custos na avaliação, bem como os resultados obtidos. 


\section{B2.1) Metodologia Adotada}

Para a avaliação dos custos externos é adotada uma abordagem qualitativa. Dessa forma, o que se busca nesta fase é evidenciar as externalidades associadas a cada recurso.

As etapas de avaliação são as seguintes:

1. Estudo dos possíveis impactos de cada recurso;

2. Montagem de uma Matriz de Avaliação de Impactos;

3. Definição de Pesos e Significâncias para cada impacto;

4. Aplicação da Matriz para cada cenário;

5. Discussão dos resultados.

\section{B2.2) Descrição dos Impactos}

Onde são descritos, sucintamente, os possíveis impactos associados a cada recurso, conforme item 2.2.

\section{B2.3) Matriz de Avaliação e Resultados}

Para realizar a avaliação, selecionam-se os indicadores mais representativos quanto aos impactos, que são assim classificados:

Ambientais: Emissões aéreas, Efeitos na água, Efeitos no solo;

Sociais e Culturais: Fluxos migratórios, População, Empregos, Usos múltiplos.

Para cada um desses indicadores é atribuído um peso de acordo com um critério estabelecido. A avaliação em si é dada pela significância de cada impacto. 
A estrutura da matriz utilizada é mostrada a seguir.

Tabela 4.13 : Estrutura da Matriz de Avaliação de Impactos

\begin{tabular}{|c|c|c|c|c|c|}
\hline \multirow[t]{2}{*}{ Impactos } & \multirow[t]{2}{*}{ Peso } & \multicolumn{3}{|c|}{ Significância } & \multirow[t]{2}{*}{ Score } \\
\hline & & $\mathrm{B}$ & $\bar{M}$ & $A$ & \\
\hline \multicolumn{6}{|l|}{ Ambientais } \\
\hline \multicolumn{6}{|l|}{ Sociais } \\
\hline \multirow{2}{*}{\multicolumn{5}{|c|}{ Culturais }} & \\
\hline & & & & & \\
\hline
\end{tabular}

Nesta matriz, os pesos estão associados à forma (direta ou indireta) com que os impactos afetam o ser humano e a significância à intensidade desses impactos (Baixa, Média ou Alta).

Os resultados obtidos nesta avaliação são mostrados na tabela 5, onde quanto maior o score, melhor é a avaliação da alternativa quanto às externalidades e, portanto, menor serão os seus impactos. Dessa forma, os valores permitem uma ordenação das alternativas quanto aos impactos causados.

\subsubsection{Avaliação Final dos Custos Completos}

A avaliação completa de cada cenário deve levar em consideração tanto os custos internos quanto os externos. Esses custos foram assim considerados:

Custos Internos: indica qual a alternativa mais viável sob o ponto de vista econômico;

Custos Externos: orienta sobre qual alternativa produz menores impactos. 
Dessa forma, a alternativa mais atraente é aquela que possui menor custo de geração de energia e menor impacto, onde subentende-se ter um menor custo externo.

É importante ressaltar que todas as alternativas são passíveis de utilização de acordo com determinados condicionantes, o que é analisado no plano indicativo.

\subsubsection{Plano Indicativo para as Alternativas}

A partir da análise dos resultados obtidos, elabora-se um plano de aproveitamento dos recursos selecionados dentro dos cenários propostos, tendo em vista o horizonte de tempo definido do projeto. 


\section{GIR - ESTUDO DE CASO}

\subsection{O Caso Estudado: Energia Elétrica, Água / Irrigação / Produção}

\section{Agrícola}

Para efeito de exemplificação dos conceitos abordados, procede-se aqui a um estudo de caso englobando o uso da água para geração de energia elétrica e irrigação.

O caso estudado prevê a construção de uma pequena central hidrelétrica $(\mathrm{PCH})$ e a consideração de um projeto para inclusão de uma nova cultura agrícola na região, mediante a implantação de um sistema de irrigação. O estudo será baseado em dados da região do Médio Paranapanema.

Será estudado um possível modelo de gestão integrada para compatibilização dos interesses envolvidos, tanto do ponto de vista do produtor rural como do produtor de energia elétrica.

\subsubsection{O Problema Isolado}

A utilização da água de um reservatório para geração de energia elétrica deve estabelecer limites máximos e mínimos do nível do mesmo, para que haja utilização eficiente do ponto de vista elétrico.

A irrigação, por sua vez, compete com a geração e dispõe do direito de utilização de parcela do mesmo curso d'água, e, dependendo do montante pode vir a comprometer o retorno do capital investido na usina, pois representa redução da água para geração (água turbinada). Da mesma forma, a 
consideração apenas do volume de água sem a parcela da irrigação incorre em sub aproveitamento do recurso para geração, pois este percentual de retirada de água pode não ocorrer no período de recuperação do capital da usina.

Atualmente, o montante permitido de retirada de água, para fins de irrigação, é estabelecido pelo Código Nacional de Águas, e está fixado em 30 \% da vazão regularizada de um curso d'água. Com a criação, já em andamento, da Agência Nacional de Águas - ANA, podem ocorrer mudanças na regulação do setor, existindo a possibilidade de alteração deste percentual. Para a elaboração deste estudo de caso foi adotado o percentual de $30 \%$ de retirada para irrigação.

Desta forma, a produção de energia elétrica e o uso para irrigação têm competido pelo uso da água, gerando conflitos e problemas para ambos os lados (aceitabilidade).

\subsubsection{A Gestão Integrada}

No caso proposto será estudada a gestão integrada da água, para disponibilização de energia elétrica e um sistema de irrigação, considerando um possível modelo que compatibilize os aspectos diferenciados destes diferentes usos da água.

Neste modelo será proposta a atuação do Estado, como financiador e facilitador; do Comitê de Bacia, como ente regulador e viabilizador da irrigação e da PCH, através de ações regulatórias diferenciadas, que compatibilizem o uso da água. 
Serão analisados os retornos financeiros dos investimentos isoladamente dentro do contexto atual e conjuntamente através de um modelo de Gestão Integrada de Recursos. Também serão comparados os desempenhos sociais e ambientais em ambos os casos.

Uma característica do estudo da GIR que deve ser ressaltada é quanto ao nível de detalhamento que tal abordagem exige. Ao contrário do planejamento, que trata de previsões e tendências, que podem ser analisadas em um nível macro, a GIR (pela própria definição contida em seu nome), implica em gerenciamento. O gerenciamento requer dados e avaliações bem mais específicas e detalhadas que o planejamento, pois refere-se à implantação e operação da infra-estrutura.

Dessa forma, enquanto o planejamento aponta a necessidade de energia elétrica para uma região, a gestão, irá implantá-la e operá-la, necessitando saber exatamente quantos consumidores há na região, suas características, o quanto de energia é necessária, como será gerada etc..

Este estudo de caso adota simplificações neste sentido, mas, muitos dos detalhes que foram necessários ao seu desenvolvimento foram mantidos no corpo central do texto, à medida em que foram sendo necessários, como forma de se avaliar a abrangência e multidisciplinaridade requeridas pela abordagem da GIR. 


\subsection{Caracterização da Região de Estudo: Médio Paranapanema - MPP}

\subsubsection{Características Sócio-Econômicas e Fundiárias}

A região do MPP é a terceira região mais pobre do Estado de São Paulo, apresentando um déficit significativo de infra-estrutura e desenvolvimento, sendo por isso considerada neste estudo.

As necessidades básicas da região podem ser bem caracterizadas através de uma visão global da situação atual do MPP, como na Tabela 5.1 a seguir.

\section{Tabela 5.1: Números Característicos do Vale do Médio Paranapanema}

\begin{tabular}{|l|c|c|c|c|c|}
\hline \multicolumn{1}{|c|}{ ANO } & 1989 & 1990 & 1991 & 1992 & 1993 \\
\hline População & 199.467 & 202.340 & 207.045 & 210.893 & 213.949 \\
\hline Água Encanada (Usuários) & 35.245 & 33.777 & 35.365 & 46.393 & 29.402 \\
\hline Rede de Esgoto (Usuários) & 28.152 & 25.732 & 29.059 & 25.438 & 24.984 \\
\hline consumo de EE (MWh) & 170.340 & 177.494 & 187.063 & 193.673 & 198.871 \\
\hline Consumidores de EE & 48.270 & 49.814 & 53.043 & 55.694 & 58.342 \\
\hline Pessoal Ocupado (In Co Se) & 23.551 & 23.267 & 12.444 & 25.250 & 27.350 \\
\hline Credito Rural (US\$ 94) & 126279446 & 95029222 & 81498842 & 82694542 & 87375090 \\
\hline Receita Municipal (US\$ 94) & 48381457 & 53131097 & 48122149 & 44113339 & 49235782 \\
\hline Investimento per Capita (US\$/Hab.) & 40,64 & 56,27 & 53,60 & 37,40 & 19,57 \\
\hline PIB per Capita* (US\$/Hab.) & 1.550 & 2.100 & 1.890 & 1.880 & $1.690^{*}$ \\
\hline $\begin{array}{l}\text { * Valor inferido através do indicador de Intensidade de EE (relativo a São Paulo) e relacionado ao investimento } \\
\text { per capita da região }\end{array}$ & & & & \\
\hline
\end{tabular}

Fonte: Gimenes, 1997. [Ref. 29]

A estrutura fundiária é caracterizada pela predominância de pequenas propriedades rurais, o que caracteriza produtores de baixa renda.

A Tabela 5.2 apresenta a divisão fundiária nos municípios do CIERGA Consórcio Intermunicipal da Região do Governo de Assis. 
Tabela 5.2: Caracterização Fundiária da Região do CIERGA, 1985.

\begin{tabular}{|c|c|c|c|}
\hline \multirow[b]{2}{*}{ MUNICÍPIO } & \multicolumn{3}{|c|}{ ESTABELECIMENTOS } \\
\hline & $\begin{array}{c}\text { PEQUENO } \\
\% \mathrm{~N}^{\circ} \\
\end{array}$ & $\begin{array}{l}\text { MÉDIO } \\
\text { \%ÁREA }\end{array}$ & $\begin{array}{l}\text { GRANDE } \\
\text { \%ÁREA }\end{array}$ \\
\hline ASSIS & 73.03 & 29.23 & 41.85 \\
\hline CAMPOS NOVOS & 60.05 & 35.40 & 31.44 \\
\hline CÂNDIDO MOTA & 70.43 & 47.58 & 10.79 \\
\hline CRUZÁLIA & 64.38 & 40.86 & 21.76 \\
\hline ECHAPORÃ & 56.73 & 27.62 & 47.59 \\
\hline FLORÍNEA & 58.15 & 36.17 & 33.48 \\
\hline IBIRAREMA & 74.12 & 39.24 & 25.64 \\
\hline LUTÉCIA & 46.59 & 34.14 & 39.94 \\
\hline MARACAÍ & 70.18 & 37.20 & 30.72 \\
\hline PALMITAL & 76.05 & 38.90 & 20.21 \\
\hline PARAGUAÇÚ & 64.04 & 30.86 & 44.00 \\
\hline BORÁ & 37.50 & 37.89 & 38.73 \\
\hline OSCAR BRESSANE & 65.86 & 43.32 & 22.02 \\
\hline QUATÁ & 52.99 & 18.30 & 65.29 \\
\hline PLATINA & 54.13 & 30.68 & 46.31 \\
\hline ESTADO & 75.93 & 29.83 & 41.44 \\
\hline
\end{tabular}

Fonte: Censo Agropecuário- IBGE, 1985. (AEDAS, 1999, [Ref. 34])

Nota-se que no município de Cruzália, que balizará este estudo, mais de $60 \%$ dos produtores são de pequeno porte, ou seja, com propriedades de tamanho inferior à 50 ha.

\subsubsection{Características Físicas}

Os dados aqui utilizados são resultado de um estudo realizado na região para o projeto AEDAS [Ref. 34] e se referem aos municípios de: Assis, Campos Novos Paulista, Cândido Mota, Cruzália, Florínea, Ibirarema, Lutécia, Maracaí, Palmital, Paraguaçú Paulista, Pedrinhas Paulista, Platina e Tarumã, somando, aproximadamente, 552.500 ha. 
A seguir é apresentado um extrato do texto do Projeto A.E.D.A.S [Ref. 34], referente ao clima e solo da região.

\subsubsection{Clima}

O clima da região, segundo a classificação de Koppen, é moderadamente úmido, sem estação seca.

A época mais chuvosa, no verão, com precipitação média mensal superior a $100 \mathrm{~mm}$ corresponde aos meses de outubro a março e a época mais seca em julho e agosto, apresentando precipitação média inferior a $50 \mathrm{~mm}$, (mínimo de $35 \mathrm{~mm}$ ).

A precipitação anual atinge valores médios de $1.260 \mathrm{~mm}$.

Quanto ao regime térmico, a região apresenta temperatura anual em torno de $22{ }^{\circ} \mathrm{C}$, com o mês mais frio, em julho, próxima a $18{ }^{\circ} \mathrm{C}$ e o mês mais quente, fevereiro, com temperatura em torno de $25^{\circ} \mathrm{C}$.

A umidade relativa apresenta valores médios variando entre $68 \%$ e $78 \%$, e, enquanto os valores máximos de cada mês apresenta uma alta uniformidade, em torno de $92 \%$, os valores mínimos manifestam maior variabilidade, com valores mais altos, em torno de $65 \%$, entre março e junho e valores mais baixos entre agosto e outubro, cerca de $50 \%$.

\subsubsection{Solos}

De uma maneira geral, os solos de maior ocorrência na bacia do médio Paranapanema são: Latossolo Roxo, Latossolo Vermelho Escuro, Terra Roxa 
Estruturada, Hidromórfico, Podzólico Vermelho Escuro, Cambissolo, Litólico e Solos Aluviais.

Desses solos, os quatro primeiros predominam na parte alta, enquanto os hidromórficos predominam nas partes baixas, adjacentes aos rios.

Os Latossolos Roxos, que serão os enfocados neste estudo de caso, são solos argilosos, porosos, muito friáveis, excessivamente drenados. São predominantemente eutróficos e de boa fertilidade. Encontram-se sob condições de relevo plano a suave ondulado e apresentam baixa suscetibilidade à erosão. A exploração atual destes solos é dominado pelas culturas de soja e algodão no verão, e pelo trigo e pelo milho de safrinha no Inverno.

\subsubsection{Recursos Hídricos}

A seguir têm-se as vazões conhecidas dos rios da região do Médio Paranapanema (Fukuda, 1996, [Ref. 23]).

Tabela 5.3: Vazões Características dos Rios da Região do MPP

\begin{tabular}{|c|c|c|c|c|c|c|c|c|c|c|c|c|c|c|c|}
\hline Rio & Jan. & Fev. & Março & Abril & Maio & Jun. & Julho & Ago. & Set. & Out. & Nov. & Dez. & Média & Mín. & Máx. \\
\hline $\begin{array}{l}\text { Peixe - } \\
\text { Marília-Assis }\end{array}$ & 3,78 & - & 6,83 & - & 9,33 & - & 5,03 & - & 3,61 & - & 5,58 & - & 5,69 & $\overline{3,61}$ & 9,33 \\
\hline $\begin{array}{l}\text { Peixe - } \\
\text { Emilianópolis } \\
\text { Flora-Rica }\end{array}$ & 70,68 & - & 107,57 & - & 59,64 & - & 57,41 & - & 47,49 & - & 46,15 & - & 64,82 & 46,15 & 107,57 \\
\hline Capivara & 22 & 36 & 20 & 22 & 18 & 17 & 16 & 14 & 14 & 15 & 15 & 14 & 18,58 & 14 & 36 \\
\hline \begin{tabular}{|l} 
Paranapan. \\
Barr.Capivara \\
\end{tabular} & 1038,7 & - & 1412,8 & - & 769,6 & - & 1389,7 & - & 767,2 & - & 1278,7 & - & 1109,45 & 767,2 & 1412,8 \\
\hline Pari & 17 & 17 & 16 & 14 & 13 & 14 & 11 & 11 & 9 & 9 & 11 & 11 & 12,75 & 9 & 17 \\
\hline Outros & & & & & & & & & & & & & 17,56 & 0 & 0 \\
\hline $\begin{array}{l}\text { Vazão Média } \\
\text { Mensal em } \\
\mathrm{m}^{3} / \mathrm{s}\end{array}$ & & & & & & & & & & & & Total & 1228,86 & & \\
\hline
\end{tabular}




\subsection{Energia Elétrica: Geracão Através de uma PCH}

A usina considerada será suposta no rio Capivara, da região do Médio Paranapanema. As PCHs são isentas do pagamento de outorga pelo uso da água, que nas médias e grandes usinas fica em $6 \%$ do valor da energia vendida. Além disso, através da nova legislação do setor elétrico, a ANEEL Agência Nacional de Energia Elétrica, estabeleceu tarifas diferenciadas de transmissão para facilitar a implantação deste tipo de geração.

A motivação da construção se daria, em primeira instância, para o atendimento da ponta e também para suprir o déficit energético da região, que apresenta grande percentual de demanda reprimida, conseqüência de seu baixo desenvolvimento. Além disso, contempla-se a venda de energia para fora da região, através do sistema interligado.

\subsubsection{Dimensionamento}

O rio Capivara conforme a Tabela 5.3, apresenta as seguintes vazões:

Máxima: $36 \mathrm{~m}^{3} / \mathrm{s}$;

Mínima: $14 \mathrm{~m}^{3} / \mathrm{s}$;

Média: $18,6 \mathrm{~m}^{3} / \mathrm{s}$

Considerando-se a possibilidade da construção de uma barragem que permita uma vazão regularizada igual à média anual do rio temos:

Potência:

$$
P=9,81 . h \cdot Q \cdot H
$$


Onde:

$\mathrm{P}=$ potência $(\mathrm{kW})$

$\mathrm{h}$ = eficiência do grupo gerador - turbina

$\mathrm{Q}=$ vazão da água $\left(\mathrm{m}^{3} / \mathrm{s}\right)$

$\mathrm{H}$ = queda líquida.

Considerando-se uma queda líquida de $12 \mathrm{~m}$ tem-se:

$P_{\text {média }}=9,81 \cdot 0,8 \cdot 18,6 \cdot 12=1751,7 \mathrm{~kW}$

Ou 1,75 MW de potência elétrica média.

Para uma operação de 8760 h/ano a energia total produzida será de:

$15330 \mathrm{MWh} / \mathrm{ano}$.

\subsubsection{Análise de Viabilidade Econômica da PCH}

A análise que se segue foi desenvolvida segundo a metodologia descrita no capítulo 4, item 4.3.1.1.

\subsubsection{Valores de Referência / Dados Básicos}

De acordo com a metodologia descrita no item 4.3.1 foram utilizados os seguintes valores de variáveis:

P : Potência instalada: 2500 MW (ver comentários sobre FC- Fator de Capacidade, aseguir). 
Cp : Custo unitário da Potência Instalada: considerado neste caso como sendo Cp : 1000 US $\$ / k W$. O custo considerado para tal instalação foi de US\$1000,00/kW, baseado em dados relativos à PCH-Ubirajara Machado de Moraes, de potência instalada de $800 \mathrm{~kW}$, pertencente ao Departamento Municipal de Eletricidade de Poços de Caldas - MG (Fukuda, 1996, [Ref. 23]).

j : Taxa de recuperação anual da parcela de Investimento. Vai depender da modalidade do investimento efetuado.

Com : Percentual da Parcela inicial de Investimento, correspondente aos custos anuais de Operação e Manutenção. Foi utilizado o valor de $5 \%$, segundo recomendação da Eletrobrás.

FC : Fator de Capacidade da Usina. Considerou-se neste trabalho, a operação anual de 8760 horas com $\mathrm{FC}=0,70$. Na realidade, este fator dependerá de um estudo de otimização, que considere o regime de vazões, a forma de regularização e a carga alimentada [Ref.2]. No caso adotou-se 0,70, apenas como referência, uma vez que a carga que define este número dependerá do resto do sistema: quem será alimentado?, haverá venda de energia para fora da região? etc.. Isto porque a irrigação considerada na análise é apenas uma parte muito pequena da carga.

A partir destes valores a Potência máxima será de 2.500 kW, e então o investimento total será de US $\$ 2,5$ milhões. 


\subsubsection{Taxas e Encargos}

\section{A) Reserva Geral de Reversão - RGR}

Não incluída, por se tratar de PIE - Produtor independente de Energia.

B) Parcela de Interconexão

Foi assumido o custo médio de 0,4 US\$/MWh, para interligação em 138 kV, com 8 km de distância.

C) Tarifa de Transporte de Energia

Não incluída, por se tratar de PCH antes de 2003, isenção concedida pela ANEEL.

D) Acréscimos de Custos Dependentes do Faturamento

No caso de suprimento de concessionárias, assumiu-se a tarifa de 71 $\mathrm{R} \$ / \mathrm{MWh}$, referência da ANEEL para PCHs (valor normativo). Para efeito dos cálculos procedidos neste estudo, foi considerado o valor correspondente em dólares americanos que, para a taxa de câmbio vigente em dezembro de 1999 - 2R $\$ /$ US $\$$, equivaleria aproximadamente à $35 \mathrm{US} \$ / \mathrm{MWh}$. 


\subsubsection{Avaliação Econômica Segundo a Prática Tradicional do Setor Elétrico}

A análise apresentada a seguir, considerando a prática tradicional do setor elétrico, parte de taxas de retorno e tempos de retorno pré-fixados e é elaborada com base em relações de Custos e Benefícios.

Nestes casos, se considerou tempo de retorno de 50 anos, que é o tempo de vida útil assumido para PCHs, (Eletrobrás, 1999, [Ref. 25]).

A taxa de retorno foi variada em 10, 12 e $15 \%$, para ilustrar a sensibilidade dos resultados a esta variável.

Esta análise considera as diversas alternativas apresentadas para variáveis do problema, assim como diferenciação na forma de comercialização da energia.

\section{A) Resultados - Custos da Geração Propriamente Dita, Sem Acréscimos}

Estes custos, para as diversas situações avaliadas são apresentados na Tabela 5.4.

Tabela 5.4: Custos da Geração Propriamente Dita, Sem Acréscimos

\begin{tabular}{|c|c|c|c|c|c|}
\hline Caso & & \multicolumn{4}{|c|}{ Custo Unitário da Energia Elétrica (US\$MWh) } \\
\hline $\mathbf{( 1 )}$ & $\begin{array}{c}\text { Investimento } \\
\text { Inicial } \\
\text { (milhões US\$) }\end{array}$ & $\begin{array}{c}\text { Energia } \\
\text { Anual } \\
\text { (GWh) }\end{array}$ & $\begin{array}{c}\text { Parcela } \\
\text { Invest } \\
\text { (US\$/MWh) }\end{array}$ & $\begin{array}{c}\text { Parcela } \\
\text { O\&M } \\
\text { (US\$/MWh) }\end{array}$ & TOTAL \\
\hline Base(*) & 2,5 & 15,33 & 19,63 & 8,15 & 27,78 \\
\hline j 10\% & 2,5 & 15,33 & 16,45 & 8,15 & 25,59 \\
\hline j 15\% & 2,5 & 15,33 & 24,48 & 8,15 & 32,63 \\
\hline Com 2,5\% & 2,5 & 15,33 & 19,63 & 4,07 & 23,71 \\
\hline Perda - 30\% & 2,5 & 10,73 & 28,06 & 11,64 & 39,71 \\
\hline
\end{tabular}

$\left(^{*}\right)$ Dados do Caso Base : $P=2,5 \mathrm{MW}$; Cp $=1000$ US $\$ / k W ; j=12 \% ; \quad N=50$ anos, Com $=5 \%$ Inv; $F C=0,70$. 
(1) Esta coluna indica a variável que foi alterada, com relação ao Caso Base.

B) Resultados - Custos Com Acréscimos Devidos à Taxas e Encargos, Interconexão e Tarifa de Transporte

Os resultados destes cálculos são apresentados na tabela 5.5, para venda à Concessionárias.

Tabela 5.5 :Taxas, Encargos e Outros Acréscimos Venda à Concessionárias

\begin{tabular}{|c|c|c|c|c|c|c|}
\hline Caso (1) & $\begin{array}{c}\text { Custo Unitário da } \\
\text { Energia Elétrica }\end{array}$ & \multicolumn{3}{|c|}{$\begin{array}{c}\text { Taxas e Encargos } \\
\text { [ US\$/MWh] }\end{array}$} & \multicolumn{2}{c|}{$\begin{array}{c}\text { Percentual do Custo } \\
\text { Unitário Ce (\%) }\end{array}$} \\
\hline & & Parcela 1 & \multicolumn{2}{|c|}{ Parcela 2 } & Parcela & TOTAL \\
\hline & & $\left(^{* *}\right)$ & Intercon & Transporte & Parcela 1 & Parcela 2 \\
\hline Base $\left(^{*}\right)$ & 27,78 & 1,102 & --- & --- & 3,96 & - \\
\hline $\begin{array}{c}\text { Custos de } \\
\text { Interconexão }\end{array}$ & 27,78 & 1,102 & 0,70 & --- & 3,96 & $2,52 \%$ \\
\hline
\end{tabular}

(*) Dados do Caso Base : Como os da Tabela 5.4, com :

Tarifa de venda à concessionária $=35,00$ US $\$ / M W h$;

Parcelas de Transporte $=0,0\left(^{* \star}\right)$ COFINS + PIS + Taxa de Fiscalização $=$ $3,15 \%$

(1) Esta coluna indica as variáveis que foram alteradas, com relação ao Caso Base.

C) Avaliação dos Resultados

Destas tabelas podem ser retiradas as seguintes conclusões principais :

a) Em todos os casos analisados a parcela referente aos encargos e taxas, sem inclusão do Imposto de Renda e Contribuição Social, ficou em torno de no máximo $6,5 \%$ do custo total da energia.

Esta porcentagem vai depender largamente da diferença entre o preço unitário de venda e o custo unitário da energia, sem acréscimos. 
Considerando-se a tarifa normativa que a ANEEL fixou para PCHs, de aproximadamente 36 US $\$ \mathrm{MWh}$ a diferença máxima chegou a 12,30 US\$/MWh, para o caso de manutenção a 2,5\% e o pior caso se configurou com a redução de $30 \%$ na geração de energia, que produziu um prejuízo de 3,71 US\$ /MWh, inviabilizando a PCH. O caso base apresentou diferença de 8,22 US\$/MWh.

5.3.2.4 Investimento Efetuado no Contexto de Mercado Competitivo, Sem Alavancagem

Neste caso, as variáveis tarifa de venda, taxa e tempo de retorno são tratadas como independentes, uma vez que o investimento a ser efetuado deverá competir com outras alternativas do mercado.

Pode-se considerar aí, três enfoques alternativos do problema:

- fixa-se a tarifa e a taxa desejada e determina-se o tempo de retorno;

- fixa-se a tarifa e o tempo de retorno desejado e determina-se a taxa de retorno;

- fixa-se a taxa e o tempo de retorno, determinando-se a tarifa.

A fixação de variáveis e o critério de avaliação, com base no valor da variável determinada, obviamente dependerão do cenário do mercado, quando da análise do investimento. 
Como referência comparativa com análise efetuada segundo a prática usual do setor elétrico, considerou-se o "Caso Base", com taxas, encargos e outros acréscimos.

Para este caso Base, tem-se as seguintes variáveis:

$P=2,5 \mathrm{MW} ; C_{p}=1000$ US $\$ \mathrm{~kW} ; C_{o m}=5 \% \operatorname{Inv} ; F C=0,70$

Parcelas de Interconexão $=$ US $\$ 0,4 / \mathrm{MWh}, \mathrm{CCC}$ e Transporte = 0,0;

No caso analisado, o custo unitário da energia elétrica, com as taxas, resultou em cerca de 29,58 US\$/MWh (soma dos componentes da primeira linha da Tabela 5.6), que corresponde à taxa de juros de $12 \%$ e tempo de retorno de 50 anos.

A Tabela 5.6 a seguir apresenta resultados de avaliações efetuadas fixando-se duas das variáveis independentes e calculando-se a terceira.

Tabela 5.6: Resultados para um Mercado Competitivo, Sem Alavancagem

\begin{tabular}{|c|c|c|c|c|}
\hline Caso & \multicolumn{2}{|c|}{$\begin{array}{c}\text { Custo Unitário da Energia } \\
\text { Elétrica }\end{array}$} & $\begin{array}{c}\text { Tempo de } \\
\text { retorno }\end{array}$ & $\begin{array}{c}\text { Taxa de } \\
\text { retorno }\end{array}$ \\
\hline & \multicolumn{2}{|c|}{ [USW] } & Anos & porcento \\
\hline Base & 27,78 & 29,58 & 50 & 12 \\
\hline A 1 & 28,94 & 30,74 & 25 & 12 \\
\hline A 2 & 37,01 & 38,81 & 10 & 12 \\
\hline B 1 & 33,38 & 35,18 & 25 & 15 \\
\hline B 2 & 40,64 & 42,44 & 10 & 15 \\
\hline C 1 & 23,43 & 25,23 & 25 & 8 \\
\hline C 2 & 32,45 & 34,25 & 10 & 8 \\
\hline D 1 & 20,91 & 22,71 & 25 & 6 \\
\hline D 2 & 30,30 & 32,12 & 10 & 6 \\
\hline
\end{tabular}




\section{A) Avaliação dos Resultados}

Os resultados apresentados indicam que a diminuição do tempo de retorno desejado, para uma mesma taxa de retorno, tem um impacto significativo nos custos unitários da energia e portanto no lucro, caso o custo total com taxas se enquadre dentro de um valor competitivo. Como os valores se reduzem com a redução da taxa de retorno, permitindo-se visualizar aumento da competitividade, pode-se considerar que (para venda à média de 36 US $\$ / M W h)$, à taxas internacionais de juros de $6 \%$ a $8 \%$ ao ano, o projeto sob análise poderia ser competitivo, para um tempo de retorno de 25 anos, que corresponde à metade da vida útil da usina. Tanto numa como noutra taxa, o custo da energia é inferior ao conseguido no caso base, que considera os valores usuais do setor elétrico.

\section{4 Água: O Uso para Irrigação e a Produção Agrícola}

Neste estudo de caso será considerada a mudança de cultura viabilizada pela implantação de um sistema de irrigação.

A cultura inicialmente considerada será a soja, predominante na região, com posterior mudança para o cultivo da pupunha (Bactris gasipaes H.B.K.), uma espécie de palmito melhor adaptada à produção em larga escala.

A seguir serão levantados alguns dados pertinentes à cada cultura, que posteriormente permitirão a análise de retorno do capital empregado. Os dados abordarão as características gerais de cada cultura e também sua adequação à região do Médio Paranapanema descrita no item 5.2. 
A quantidade e as características da necessidade de irrigação serão determinadas a partir destes aspectos.

\subsubsection{A Propriedade Estudada}

Como a maior parte dos produtores rurais da região do Médio Paranapanema é composta de pequenos produtores (vide Tabela 5.2), este estudo irá considerar uma propriedade de 50 ha. Trata-se de uma pequena propriedade, que, como será visto adiante, costuma apresentar baixa rentabilidade ao produtor, no cultivo de grãos.

As grandes propriedades costumam contar com recursos próprios suficientes, ou mesmo fácil acesso ao crédito, e por isso não foram alvo deste estudo.

Por proximidade ao rio Capivara, considerado para implantação da $\mathrm{PCH}$, a propriedade seguirá as características do município de Cruzália, que serão discutidas conforme necessitadas durante o texto.

\subsubsection{A Soja}

\subsubsection{Clima}

As temperaturas médias, ótimas para o melhor desenvolvimento da soja são entre 20 e $35^{\circ} \mathrm{C}$ e precipitações pluviométricas anuais de 700 a $1.200 \mathrm{~mm}$ bem distribuídas. Essas condições são encontradas em todo o planalto paulista, que se mostra apto para o desenvolvimento da cultura. (Dihel e Junquetti, [Ref.32]). 


\subsubsection{Solos}

Limitações por fertilidade não são de muita importância para a soja, pois essa reage otimamente à adubação. A maior limitação para a cultura no aspecto solo é a sua declividade, que se maior de $12 \%$ torna difícil a mecanização.

Um tipo muito bom de solo para o seu cultivo é o Latossolo Roxo (presente em boa parte da região do Médio Paranapanema). (Dihel e Junquetti, [Ref.32]).

\subsubsection{Adequação às Características da Região do Médio Paranapanema - MPP}

Na região do MPP, a soja é cultivada geralmente em conjunto com o milho safrinha. A seguir tem-se as Tabelas $5.7,5.8$ e 5.9 com os custos e rentabilidade deste plantio, de acordo com o tamanho da propriedade, para os municípios da região do CIERGA. Para os dados a seguir foi considerado o tipo de solo Latossolo roxo (AEDAS, 1999, [Ref. 34]).

Tabela 5.7: Viabilidade Econômica de um Estabelecimento Produtor de Grãos de 50 ha, na Região do CIERGA

\begin{tabular}{|c|c|c|c|c|c|c|c|}
\hline & Soja & Milho & Receita & COT & & Renda & Salário \\
\hline $\begin{array}{l}\text { Sistemas de } \\
\text { produção }\end{array}$ & Prod./ha & Prod./ha & Total & Total & Lucro & Mensal & Mínimo $^{2}$ \\
\hline $\begin{array}{l}\text { soja latossolo milho } \\
\text { safrinha baixa }\end{array}$ & 40 & 37,5 & 37552,50 & 29178,00 & 8374,50 & 644,19 & 4,96 \\
\hline $\begin{array}{l}\text { soja latossolo milho } \\
\text { safrinha alta }\end{array}$ & 40 & 37,5 & 43824,00 & 32873,50 & 10951.85 & 842.45 & 6,48 \\
\hline $\begin{array}{l}\text { soja plantio direto } \\
\text { milho safrinha baixa }\end{array}$ & 40 & 37,5 & 37552,50 & 29644,00 & 7908,50 & 608,35 & 4,68 \\
\hline $\begin{array}{l}\text { soja plantio direto } \\
\text { milho safrinha alta }\end{array}$ & 40 & 55,17 & 43825,35 & 33339,50 & 10484,67 & 806,60 & 6,20 \\
\hline $\begin{array}{l}\text { soja safrinha milho } \\
\text { verão }\end{array}$ & 25 & 37,5 & 28462,50 & 33240,50 & 4778,00 & $-367,54$ & $-2,83$ \\
\hline
\end{tabular}

Fonte: Resultados da Pesquisa [Ref. 34]

1. Preços em Reais de $21 / 07 / 97$

2. Mensal 
Tabela 5.8: Viabilidade Econômica de um Estabelecimento Produtor de Grãos de 75 ha, na Região do CIERGA

\begin{tabular}{|c|c|c|c|c|c|c|c|}
\hline Sistemas de & Soja & Milho & Receita & COT & & Renda & Salário \\
\hline Produção & Prod./ha & Prod./ha & Total & Total & Lucro & Mensal & Mínimo \\
\hline $\begin{array}{l}\text { soja latossolo milho } \\
\text { safrinha baixa }\end{array}$ & 40 & 37,5 & 56328,75 & 43702,00 & 12626,75 & 971,29 & 7,47 \\
\hline $\begin{array}{l}\text { soja latossolo milho } \\
\text { safrinha alta }\end{array}$ & 40 & 55.17 & 65738,03 & 49245,25 & 16492.78 & 1268,68 & 9,76 \\
\hline $\begin{array}{l}\text { soja pl. Direto milho } \\
\text { safrinha baixa }\end{array}$ & 40 & 37,5 & 56328,75 & 44401,00 & 11927,75 & 917,52 & 7,06 \\
\hline $\begin{array}{l}\text { soja pl. Direto milho } \\
\text { safrinha alta }\end{array}$ & 40 & 55,17 & 65738,03 & 49944,25 & 15793,98 & 1214,91 & 9,35 \\
\hline soja safr. Milho verão & 25 & 37,5 & 42693,75 & 49795,75 & $-7102,00$ & $-546,31$ & $-4,20$ \\
\hline
\end{tabular}

Fonte: Resultados da Pesquisa [Ref. 34]

1. Preços em Reais de $21 / 07 / 97$

Tabela 5.9: Viabilidade Econômica de um Estabelecimento Produtor de Grãos de 100 ha, na Região do CIERGA

\begin{tabular}{|c|c|c|c|c|c|c|c|}
\hline Sistemas de & Soja & Milho & Receita & COT & & Renda & Salário \\
\hline Produção & Prod./ha & Prod./ha & Total & Total & Lucro & mensal & Mínimo $^{2}$ \\
\hline $\begin{array}{l}\text { soja latossolo milho } \\
\text { safrinha baixa }\end{array}$ & 40 & 37,5 & 75105,00 & 58226,00 & 16879,00 & 1298,38 & 9,99 \\
\hline $\begin{array}{l}\text { soja latossolo milho } \\
\text { safrinha alta }\end{array}$ & 40 & 55,17 & 87650,70 & 65617,00 & 22033,70 & 1694,90 & 13,04 \\
\hline $\begin{array}{l}\text { soja plantio direto milho } \\
\text { safrinha baixa }\end{array}$ & 40 & 37,5 & 75105,00 & 59158,00 & 15947,00 & 1226,69 & 9,44 \\
\hline $\begin{array}{l}\text { soja plantio direto milho } \\
\text { safrinha alta }\end{array}$ & 40 & 55,17 & 87650,70 & 66549,00 & 21099,33 & 1623,03 & 12,49 \\
\hline soja safr. milho verão & 25 & 37,5 & 56925,00 & 66351,00 & $-9426,00$ & $-725,08$ & $-5,58$ \\
\hline
\end{tabular}

1. Preços em Reais de 21/07/97

2. Mensal

- COT - Custo operacional total, que soma a estas, outras despesas operacionais como encargos financeiros, trabalhistas, seguro, depreciação, arrendamento da terra e custos administrativos efetivos.

Como o estudo em questão refere-se à propriedades de 50 ha, nota-se, da Tabela 5.7, que a rentabilidade deste produtor é muito baixa, sendo, no melhor caso, $R \$ 842,00$ equivalentes à US\$ $420,00 /$ mês.

\subsubsection{A Pupunha}

O cultivo da pupunha no Brasil ainda é incipiente, se comparado ao da soja, e por isso as informações à seu respeito estão dispersas e muitas vezes discrepantes. Por este motivo, ao longo do texto, são citadas diversas fontes 
para um mesmo tipo de informação, para que a partir daí sejam estimados os dados necessários à avaliação que se pretende proceder neste estudo de caso.

A pupunheira é uma palmeira originária da região amazônica e que permite múltiplas utilidades, como frutos cozidos, extração de óleo, fabrico de farinha para alimentação humana e para arraçoamento animal e, ainda, a extração do palmito de excelente qualidade.

No Brasil, o palmito de pupunha, até o momento, é pouco consumido, apesar de seu excelente sabor e qualidade; no entanto, vem sendo industrializado e até exportado para outros países, como o Peru e a Costa Rica (Ferreira, [Ref. 33]).

\subsubsection{Potencial Econômico e de Mercado}

O mercado internacional de palmito está estimado em US\$ 500 milhões segundo dados da Associação Brasileira dos Produtores de Palmito (ABRAPALM). O Brasil é o maior exportador de palmito do mundo, detendo 85\% do mercado mundial. Entre os principais compradores estão: Argentina, França e Estados Unidos (Unicamp, [Ref.44]).

O mercado interno é estimado em 40 mil toneladas anuais (CERVI 1996), correspondentes a mais de 400 milhões de dólares [Ref. 44]. O maior centro consumidor do Brasil é a cidade de São Paulo, tendo consumido, só em 1994, 6.736 toneladas do produto, ou $7,5 \%$ de todo o mercado nacional. Este fato justifica o interesse pela produção de palmito no estado de São Paulo, como neste estudo de caso. 
Estes números mostram a potencialidade de mercado da produção da pupunha, cuja viabilidade econômica da produção será calculada adiante.

\subsubsection{Clima}

"A pupunha pode ser introduzida em diferentes condições climáticas, embora sua origem seja de regiões tropicais úmidas, onde apresenta maior potencialidade de desenvolvimento e qualidade do palmito.

As regiões onde o cultivo se desenvolve melhor compreendem localidades quentes e úmidas com temperatura média anual mínima de $22{ }^{\circ} \mathrm{C}$ e com precipitação pluviométrica acima de $1.600 \mathrm{~mm}$ por ano, bem distribuídos ao longo das estações do ano, considerando-se um dos fatores limitantes para o desenvolvimento do cultivo. A ausência desses fatores ocasionará maior período de tempo para a realização da colheita e menor produtividade por área cultivada." (Ferreira, [Ref. 33]).

\subsubsection{Solo}

"O cultivo da pupunha não é exigente em solos, pois observa-se seu desenvolvimento em solos de baixa fertilidade e com acidez elevada; a adição de elementos de correção do solo e fertilizações aumentam significativamente a produção.

Como característica, o solo deve ser de textura média e leve, com boa capacidade de drenagem, pois a pupunha não tolera solos encharcados.

Em relação à topografia da área a ser cultivada, consideram-se aptas as de relevo plano ou suavemente ondulado, o que facilita a mecanização, 
condução, colheita e transporte, embora não seja descartada a possibilidade de plantio em áreas de maior grau de declividade do terreno". (Ferreira, [Ref. 33]).

\subsubsection{Produtividade}

Considerando-se a plantação de 5.000 mudas em uma área de um hectare, ao longo da colheita, a mesma quantia plantada irá aumentar para 7.500 plantas aptas para o consumo. Ou seja, cada cova rende 1,5 pé de palmito de pupunha, sendo esta a média da lavoura, (Lima, 1998 [Ref. 36]).

Estima-se que a produtividade da cultura da pupunha seja de 1 a 4 t/ha de palmito. Para a produção de frutos, estima-se uma produtividade de até 20 t/ha, a partir do quarto ano. Para a produção de sementes, uma pupunheira produz até 8 cachos por ano, com mais ou menos 350 frutos cada uma, geralmente entre os meses de janeiro e abril, (Ferreira, [Ref. 33]).

Aos 18 meses, o palmito pode ter entre 150 e 300 gramas de peso. Aos três anos, pode-se colher plantas até com 500 gramas de palmito. Não é aconselhável colher a idades superiores a essa, pois o maior diâmetro do palmito trará problemas à industrialização por não corresponder, eventualmente, a capacidade da embalagem (lata ou vidro), (Agro-Fauna, 1998, [Ref. 35]).

A periodicidade de colheita é bastante variável, dependendo do material genético, clima, solo e técnicas de exploração e cultivo. Nas condições brasileiras e para o tipo de palmito de maior aceitação no mercado (acima de 2,5 cm de diâmetro), é esperado colher, no máximo, 2 palmitos por planta ao 
ano, sendo mais sensato fazer apenas uma colheita anual. Consegue-se uma produção de palmito de primeira em torno de 1,3 a 1,8 toneladas por hectare ao ano, iniciando-se a colheita 18 meses após o plantio. Igual produção é obtida da pane basal (palmito caulinar) e do ápice ("picadinho"), (Agro-Fauna, 1998, [Ref. 35]).

Segundo (Lima, 1998 [Ref. 36]), um hectare de pupunha produz cerca de $1.700 \mathrm{Kg}$ de palmito e $2.500 \mathrm{Kg}$ de subprodutos, são eles: palmitos picadinhos ou em rodelas. O preço de comercialização do subproduto é $60 \%$ do valor do palmito. Esses dados consideram o plantio de 5.000 plantas/ha, valor que garante uma maior produtividade do palmito.

\subsubsection{Custos Associados}

A cultura da Pupunha apresenta excelente viabilidade econômica. Entretanto, seu custo de implantação é elevado, situando-se em torno de $R$ \$ $4.000,00 /$ ha, com um custeio anual variando de $R \$ 500,00$ a $R \$ 800,00 /$ ha (Segundo NISHIKAWA et al., 1997) in (Lima, et al., 1999, [Ref. 41]). Este valor já inclui o custo das mudas, que varia de $R \$ 0,50$ à $R \$ 1,00$.

A estimativa de receita líquida a partir do segundo ano de implantação é atualmente de $\mathrm{R} \$ 4.000,00 /$ ha. (Lima, 1998 [Ref. 36]).

\subsubsection{Comercialização}

O produtor pode comercializar sua produção in natura ou envasada, sendo esta última mais lucrativa, porém é necessário a instalação de uma 
indústria para processamento. Estima-se que produtores isolados ou associados, com plantações acima de 300.000 pés de pupunha, já se encontram em um patamar economicamente viável para a instalação desta, (Lima, et al., 1999, [Ref. 41]).

Esta pode compor uma segunda etapa de um plano para o desenvolvimento de uma determinada região, pois a industrialização do palmito não requer um alto grau de sofisticação e agrega um valor significativo ao produto.

Segundo ainda os autores, uma fábrica para o beneficiamento de palmito deve conter basicamente três setores:

1. Setor de recepção do produto, onde o palmito é descarregado e as bainhas fibrosas remanescentes retiradas, e feita a seleção dos materiais por diâmetro e tamanho.

2. Setor de pré-processamento, onde o palmito é lavado e dividido em partes. O palmito tradicional é cortado em toletes uniformes, a base cortada em rodelas e a capa é picada. São colocados em vidro padronizados e esterilizados.

3. Setor de processamento, onde o palmito já envasado recebe uma salmoura (água + ácido cítrico + cloreto de sódio - $\mathrm{NaCl}$ ). Os vidros envasados são então cozinhados em "banho maria" por 35 minutos à $100^{\circ} \mathrm{C}$, para que o ar saia dos toletes. O palmito deve permanecer maturando nos vidros por um período de 15 a 40 dias, sendo então lacrados e rotulados.

De acordo com as informações anteriores foram assumidos os seguintes valores de produtividade, custos e lucratividade: 
Produtividade para 5000 pés/ha:

Palmito de primeira: $1600 \mathrm{~kg} / \mathrm{ha} / \mathrm{ano}$

Sub produtos (picadinho e rodelas): $2400 \mathrm{~kg}$;

Total: $4000 \mathrm{~kg} / \mathrm{ha} / \mathrm{ano}$;

\section{Custos e Prazos:}

Implantação: US\$2.000/ha;

Operação: US\$ 300/ha;

Lucratividade: US\$2.000/ha/ano após a primeira colheita.

Tempo até a primeira colheita: 18 meses.

Tais valores são conservadores em vista das estimativas mais otimistas, e portanto apresentam uma margem de segurança, que representa um resultado que não o ótimo, embora a irrigação considere uma complementação que tornaria a produtividade esperada próxima do ótimo.

Deve-se ressaltar que, após a primeira colheita, a produção é anual e contínua, além do que ela própria garante a renovação das mudas, que se multiplicam na taxa de 1,5 para cada cova plantada, existindo a possibilidade de que o produtor possa vendê-las. 


\subsubsection{Adequação às Características da Região do Médio Paranapanema}

\section{A) Segundo as Características Físicas}

O solo da região escolhido (o latossolo roxo), bem como a umidade e características climáticas se adaptam às necessidades básicas da planta, ficando a ressalva ao regime pluvial.

De acordo com as informações anteriores, vê-se a necessidade de complementação por irrigação das necessidades hídricas da pupunha. Conforme exposto, a necessidade anual da pupunha gira em torno de 1800 mm de água, enquanto a média anual da região em questão é de 1260 mm, chegando nos meses secos à $50 \mathrm{~mm}$.

Como a pupunha requer um regime bem distribuído ao longo do ano, isso significa uma média mensal de aproximadamente $150 \mathrm{~mm}$ de água. No MPP, no período seco, isso representa a necessidade de complementação de $100 \mathrm{~mm}$, ou o dobro das chuvas neste período. No período chuvoso, a complementação seria de $50 \mathrm{~mm}$ mensais. Obviamente, os cálculos aqui apresentados representam apenas uma estimativa da quantidade de água requerida, sem os cuidados devidos que seriam necessários para uma aplicação real, onde a agronomia possui estudos detalhados sobre as necessidades de irrigação dos diversos tipos de culturas.

Tal complementação deve ser feita de maneira que não haja encharcamento do solo, pois a planta não é tolerante a este fator. Isto implica em que não haja irrigação de forma concentrada em um curto período de tempo durante o dia. 


\subsubsection{Sistemas de Irrigação}

Existem diversos tipos de sistemas de irrigação, com diferentes níveis de eficiência e custos.

Segundo (Hernandez, 1989, [Ref. 42]), resumidamente, os principais são:

Sistemas de irrigação de superfície, que distribuem a água na superfície por gravidade. A água penetra no solo a partir de canais abertos. A quantidade aplicada é determinada pela taxa de porosidade do solo e pelo tempo que a água deve ficar disponível em sua superfície.

Sistemas de irrigação por aspersão, que descarregam a água através de aspersores ou de difusores instalados em tubulação de distribuição pressurizada. Os aspersores, e às vezes a tubulação, são instalados em suportes fixos ou móveis. A quantidade da aplicação é determinada pelas horas de operação.

Sistemas de irrigação localizada, tais como gotejamento ou microaspersão, que distribuem a água em espaços curtos, através de canos pressurizados. A água é descarregada a partir de emissores, mini aspersores ou de condutos porosos a baixa pressão. Estes sistemas requerem aplicações mais freqüentes do que os métodos de irrigação de superfície ou os de aspersão.

Sistemas de subirrigação, que requerem o levantamento do nível do lençol freático de modo que a ação capilar atrairá a água do solo para a zona de ação das raízes. 
Cada sistema possui características próprias que se adaptam à determinadas culturas, para este estudo de caso será considerado o sistema de aspersão, comum para o cultivo de hortaliças. O sistema de gotejemento e micro aspersão são mais eficientes quanto ao consumo de água, e têm sido mais utilizados nas culturas de citros. O cultivo da pupunha ainda prescinde de dados que possam indicar com clareza o tipo ideal do sistema de irrigação. Estudos preliminares da UNESP junto à FAPESP (Hernandez, 1999, [Ref. 43]) comprovaram um baixo desempenho desta cultura no noroeste paulista com irrigação por gotejemento, indicando a necessidade de aprofundamento neste campo.

Então, para fins desta análise, foi escolhido o sistema de irrigação por aspersão, que adapta-se bem à maioria das culturas e já tem o seu uso bastante consolidado, além de possuir um nível de eficiência aceitável.

\section{A) Sistema de Irrigação por Aspersão}

Os três tipos principais de sistemas por aspersão são (Hernandez, 1989, [Ref. 42]):

Sistemas fixos, sistemas semi-fixos e sistemas móveis.

Os sistemas de irrigação por aspersão são adequados para a maioria das plantações e são adaptáveis à maioria dos solos irrigáveis.

A pressão necessária para distribuir a água e operar os aspersores é geralmente fornecida por bombas hidráulicas.

Os sistemas de aspersores móveis irrigam o solo enquanto estão em movimento e geralmente aplicam água mais uniformemente do que os 
sistemas semi-fixos e fixos. O sistema de pivô central é o sistema móvel mais comum, cuja irrigação é feita em uma área circular. A extremidade fixa, o ponto do pivô, é ligada ao suprimento de água. A transversal consiste em uma série de torres variando em comprimento e mantidas a cerca de 3 metros acima do chão por uma unidade motriz, montada sobre rodas propelidas por motores elétricos.

A velocidade rotacional do sistema é regulada pela velocidade da unidade motriz da extremidade, a qual pode ser controlada pelo operador.

Os sistemas fixos ou de deslocação contínua, pivô central, são mais adequados para as condições em que as irrigações freqüentes e pouco intensas são necessárias, tais como para plantas de raízes rasas ou para solos com baixa capacidade de retenção de água (que será o caso em questão).

"Considerando que os aspersores descarregam a água no espaço acima das plantas, ocorre alguma evaporação. Sob condições de vento, uma parte pequena da água desvia-se da área-alvo da aplicação, acusando evaporação e desvio entre 5 a 20\% da água descarregada." (Hernandez, 1989, [Ref. 42]).

Para efeito deste estudo, foi considerado o sistema de pivô central, que possui uma eficiência relativa ao uso da água em torno de $85 \%$.

O intuito do exemplo é dotar de água propriedades de pequenos produtores. Em um segundo nível de desenvolvimento poderia-se proceder uma troca do equipamento por outras técnicas mais eficientes. 


\section{A1) Dimensionamento e Custos de Implantação e Operação}

\section{A11) Dimensionamento da Lâmina d'Água}

O dimensionamento aqui exposto, conforme já salientado, tem como objetivo apenas estimar a quantidade de água necessária e o consumo energético para sua utilização.

Como parâmetro para avaliação das chuvas locais, serão utilizados dados da região próxima à cidade de Cruzália, que se encontra próxima ao rio Capivara onde se localizou a PCH.

Assim sendo, as médias pluviométricas mensais dos últimos 20 anos, para esta região são apresentadas na Tabela 5.10.

Tabela 5.10: Média Pluviométrica Mensal do Município de Cruzália

\begin{tabular}{|c|c|c|c|c|c|c|c|c|c|c|c|c|}
\hline & Jan. & Fev. & Mar & Abr. & Maio & Jun. & Jul. & Ago. & Set. & Out. & Nov. & Dez \\
\hline média & 192,8 & 145,3 & 145,8 & 90,1 & 103,5 & 73,4 & 39,5 & 31,1 & 92,6 & 119,4 & 135,9 & 186,6 \\
\hline
\end{tabular}

Fonte: Banco de Dados Pluviométricos do Estado de São Paulo, 1997

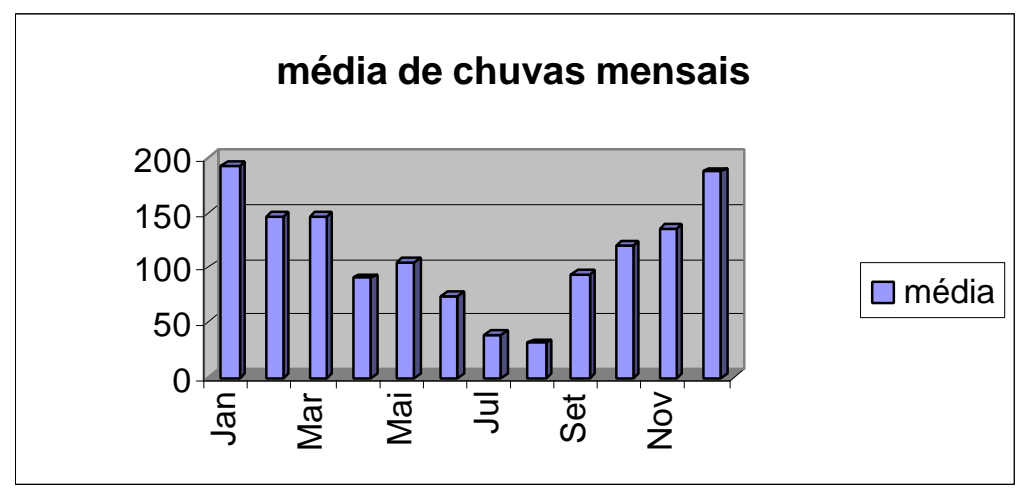

Visualização dos dados:

Figura 5.1: Gráfico das Médias Mensais Pluviométricas no Município de Cruzália

A partir destes dados, pode-se construir a Tabela 5.11, que contém as estimativas da necessidade de complementação por irrigação. 
Tabela 5.11: Estimativas Mensais da Necessidade de Irrigação

\begin{tabular}{|c|c|c|c|c|c|c|}
\hline & $\begin{array}{c}\text { média } \\
\text { pluviométrica }\end{array}$ & $\begin{array}{c}\text { média } \\
\text { necessária }\end{array}$ & $\begin{array}{c}\text { Complementação } \\
\text { para } 12 \text { meses }\end{array}$ & $\begin{array}{c}\text { Correção de } \\
15 \%\end{array}$ & $\begin{array}{l}\text { Água } \\
\text { Necessária }\end{array}$ & $\begin{array}{c}\text { Água } \\
\text { Necessária }\end{array}$ \\
\hline Mês & $(\mathrm{mm})$ & $(\mathrm{mm})$ & $(\mathrm{mm})$ & $(\mathrm{mm})$ & $\mathrm{m}^{3} / \mathrm{ha} / \mathrm{mês}$ & $\mathrm{m}^{3} / \mathrm{ha} / \mathrm{dia}$ \\
\hline Janeiro & 192,80 & 150 & $42,80^{*}$ & $49,22^{*}$ & $492,25^{*}$ & $15,87^{*}$ \\
\hline Fevereiro & 145,29 & 150 & 4,70 & 5,41 & 54,10 & 1,93 \\
\hline Março & 145,78 & 150 & 4,21 & 4,84 & 48,47 & 1,56 \\
\hline Abril & 90,1 & 150 & 59,9 & 68,88 & 688,85 & 22,96 \\
\hline Maio & 103,47 & 150 & 46,53 & 53,50 & 535,09 & 17,26 \\
\hline Junho & 73,43 & 150 & 76,57 & 88,05 & 880,55 & 29,35 \\
\hline Julho & 39,53 & 150 & 110,47 & 127,04 & 1270,40 & 40,98 \\
\hline Agosto & 31,13 & 150 & 118,87 & 136,70 & 1367,00 & 45,56 \\
\hline Setembro & 92,55 & 150 & 57,45 & 66,06 & 660,67 & 21,31 \\
\hline Outubro & 119,39 & 150 & 30,60 & 35,19575 & 351,95 & 11,73 \\
\hline Novembro & 135,85 & 150 & 14,15 & 16,27 & 162,72 & 5,24 \\
\hline \multirow[t]{2}{*}{ Dezembro } & 186,55 & 150 & $36,55^{*}$ & $42,03^{*}$ & $420,32^{*}$ & $14,01^{*}$ \\
\hline & & & & & $\mathrm{m} 3 / \mathrm{ha} / \mathrm{ano}$ & \\
\hline $\begin{array}{l}\text { total } \\
\text { acumulado }\end{array}$ & 1355,89 & 1800 & 444,11 & 510,72 & 6932,43 & 227,80 \\
\hline Média mensal & 112,99 & 150 & 37,00 & 42,56 & 577,70 & 18,98 \\
\hline
\end{tabular}

A precipitação diária mínima é identificada no mês de agosto, sendo este o pior caso para irrigação.

Isto representa uma necessidade bruta de complementação de aproximadamente $4,4 \mathrm{~mm} / \mathrm{ha} / \mathrm{dia}$.

Assim sendo dimensionou-se o seguinte sistema:

Área irrigada: 50 ha;

Precipitação diária $4,50 \mathrm{~mm}$;

Utilização: 7 dias por semana;

Altura livre entre as torres em terreno plano: $2,74 \mathrm{~m}$;

Lamina Líquida: 3,8 mm/dia; 
Eficiência da aplicação: 85 \%;

Lamina Bruta: $4,4 \mathrm{~mm} / \mathrm{dia} \quad(9,53$ horas/dia);

Área circular irrigada: aprox. 50 ha; Giro de 360 graus;

Lâmina por percurso: $1,5 \mathrm{~mm} / \mathrm{volta}$;

3 voltas em $9,5 \mathrm{~h}$;

Vazão Total: $240 \mathrm{~m}^{3} / \mathrm{h}$;

Vazão por área: 4,80 m³/h/ha;

Potência necessária para o sistema: 102 CV ou 77 kW.

Custos totais estimados: US\$ $110.000,00$ (estes custos e valores de potência foram estimados a partir dos valores de um sistema de pivô central no projeto AEDAS [Ref. 34]).

Valores por ha:

$1,54 \mathrm{~kW} / \mathrm{ha}$

US\$ $2.200,00 /$ ha.

Para complementação menor que a necessária no inverno, será considerada a redução no número de horas diárias de aplicação. Para que não haja necessidade de um número de horas diárias que impliquem em um número fracionário de voltas do sistema, este ajuste deve ser feito com base na regularização mensal.

Custos de manutenção e operação:

Os custos de operação foram considerados como sendo o da energia elétrica fornecida e 1\% em manutenção e operação: 
Manutenção: $\mathrm{R} \$ 22,00$ /ha/ano;

Operação: energia elétrica para os 50 ha:

Tabela 5.12: Custos Mensais de Energia Elétrica ( $p / 50$ ha)

\begin{tabular}{|l|c|c|c|c|}
\hline \multicolumn{1}{|c|}{ Mês } & \multicolumn{2}{|c|}{ Consumo previsto } & Tarifa $^{*}$ & Valor \\
\hline & (horas) & $\mathbf{( k W h )}$ & $\mathbf{R} \mathbf{\text { MWh }}$ & $\mathbf{R \$}$ \\
\hline Janeiro & 104 & 8008 & 78,04 & 624,62 \\
\hline Fevereiro & 11 & 847 & 78,04 & 66,07 \\
\hline Março & 10 & 770 & 78,04 & 60,06 \\
\hline Abril & 145 & 11165 & 78,04 & 870,87 \\
\hline Maio & 113 & 8701 & 78,04 & 678,68 \\
\hline Junho & 186 & 14322 & 78,04 & 1117,12 \\
\hline Julho & 268 & 20636 & 78,04 & 1609,61 \\
\hline Agosto & 289 & 22253 & 78,04 & 1735,73 \\
\hline Setembro & 139 & 10703 & 78,04 & 834,83 \\
\hline Outubro & 74 & 5698 & 78,04 & 444,44 \\
\hline Novembro & 34 & 2618 & 78,04 & 204,20 \\
\hline Dezembro & 89 & 6853 & 78,04 & 534,53 \\
\hline Total anual & 1462 & 112574 & -- & 8780,77 \\
\hline
\end{tabular}

* Este valor de tarifa corresponde à média de tarifa rural praticada na região Sudeste em 1999, segundo dados da ANEEL, 1999, [Ref. 27].

Reflexo dos custos de irrigação na lucratividade da pupunha, considerando-se manutenção e operação(energia elétrica):

Sem irrigação: US\$2.000,00 /ha/ano.

Com irrigação: US\$1.890,00 /ha/ano.

Estes valores não incluem o custo do capital para implantação do sistema de irrigação nem da troca de lavoura (custo inicial da pupunha). O que será inserido na análise a seguir. Mesmo assim, mostram que o impacto da irrigação no cultivo da pupunha não é um fator que compromete sua viabilidade. 


\subsubsection{Análise de Viabilidade Econômica da Pupunha Com o Sistema de Irrigação}

Do anteriormente exposto, obtém-se os seguintes valores, correspondentes à uma propriedade de 50 ha:

> Capital necessário para implantação da cultura: US\$100.000,00.

> Capital necessário para implantação da irrigação: US\$110.000,00.

> Custos de manutenção e operação:

- Cultura: US\$ 300,00/ha.

- Irrigação manutenção: US\$1.100,00

- Irrigação operação (energia elétrica): US\$ 4.400,00

O capital inicial é de US $\$ 210.000,00$, que deve ser desembolsado no ato da implantação da cultura e do sistema de irrigação. Além deste capital, foi considerada a necessidade de provisão, já no ato do empréstimo, de recursos para cobrir os custos durante a carência necessária à primeira produção. Como esta carência é de 18 meses os custos associados devem ser de:

Cultivo de 50 ha: US $\$ 22.500,00$

Irrigação: manutenção: US\$1.650,00

Operação: US\$ 6.600,00

Total: US $\$ 30.750,00$

Perfazendo um volume total de empréstimo de: US\$241.000,00.

Além disso, nos cálculos, foi considerada a cobrança de juros durante a carência, integralizada após a mesma. 
Após a carência de 18 meses o novo valor do empréstimo é de US\$ $285.656,51$.

Considera-se que um produtor com estas características não disponha de um montante desta ordem, assim será considerada a opção de empréstimo rural com baixos juros anuais. Ressalta-se aqui que tal produtor não conseguiria ter aprovado um empréstimo desta monta junto aos bancos. Este problema deverá ser levado em conta na análise integrada.

Características do empréstimo:

O empréstimo deverá ter carência de 18 meses, extensível à 24. Nesta modalidade de empréstimos não são amortizados os juros durante a carência.

Para efeito de cálculo, foi considerada uma modalidade de empréstimo com características próximas ao EGF (Empréstimo do Governo Federal [Ref. 45]), onde as taxas de juros efetivas são em torno de $8,75 \%$ ao ano. O prazo de pagamento, inicialmente considerado será de 5,5 anos, incluída a carência de 18 meses para o caso base, ou 6 anos no caso de 24 meses de carência. A modalidade EGF prevê prazos de pagamento de até 12 anos.

Tabela 5.13: Custos e Lucratividade do Cultivo da Pupunha

\begin{tabular}{|c|c|c|c|c|c|c|c|}
\hline & \multirow[t]{2}{*}{$\begin{array}{c}\text { Investimento } \\
\text { Inicial } \\
\text { (mil US\$) }\end{array}$} & \multirow[t]{2}{*}{$\begin{array}{c}\text { Produção } \\
4000 \mathrm{~kg} / \mathrm{ha} \\
\text { (US\$/ha) }\end{array}$} & \multirow[t]{2}{*}{$\begin{array}{l}\text { Parcela } \\
\text { Invest. } \\
\text { (US } \$ / \text { ha) } \\
\end{array}$} & \multicolumn{2}{|c|}{$\begin{array}{c}\text { Parcela } \\
\text { O\&M } \\
\text { (US\$/ha) } \\
\end{array}$} & \multirow[t]{2}{*}{$\begin{array}{l}\text { Custo } \\
\text { Total } \\
\text { US\$/ha }\end{array}$} & \multirow[t]{2}{*}{$\begin{array}{c}\text { Lucratividade } \\
\text { US } \$ / \text { ha }\end{array}$} \\
\hline & & & & Cultura & Irrigação & & \\
\hline Base $\left({ }^{*}\right)$ & 241 & 2300 & 1678 & 300 & 110 & 2088 & 212 \\
\hline j $12 \%$ & 241 & 2300 & 1800 & 300 & 110 & 2210 & 90 \\
\hline j $6 \%$ & 241 & 2300 & 1577 & 300 & 110 & 1987 & 313 \\
\hline P 7 anos & 241 & 2300 & 1076 & 300 & 110 & 1486 & 814 \\
\hline P 9 anos & 241 & 2300 & 902 & 300 & 110 & 1312 & 988 \\
\hline P 12 anos & 241 & 2300 & 753 & 300 & 110 & 1163 & 1137 \\
\hline Car. 2 anos & 241 & 2300 & 1749 & 300 & 110 & 2159 & 141 \\
\hline Perda $10 \%$ & 241 & 2070 & 1678 & 300 & 110 & 2088 & -18 \\
\hline
\end{tabular}


Base: produção 4000 kg/ha, j 8,75\%, prazo para pagamento 5,5 anos, carência de 18 meses.

Na primeira coluna são apresentadas variáveis que foram alteradas em relação ao caso base, para verificar seu efeito sobre a lucratividade.

Assim, uma propriedade de 50 ha deverá apresentar uma renda mensal apresentada na Tabela 5.14 a seguir.

Tabela 5.14: Rendas Mensais Proporcionadas pelo Cultivo da Pupunha

\begin{tabular}{|c|c|c|c|}
\hline & $\begin{array}{c}\text { Renda } \\
\text { mensal }\end{array}$ & $\begin{array}{c}\text { Renda } \\
\text { mensal }\end{array}$ & $\begin{array}{c}\text { Renda } \\
\text { mensal }\end{array}$ \\
\hline & (US\$) & (R\$) & $\begin{array}{c}\text { (salários } \\
\text { mínimos) }\end{array}$ \\
\hline Base & 883,33 & 1766,67 & 14,72 \\
\hline j 12\% & 375,00 & 750,00 & 6,25 \\
\hline j 6\% & 1304,17 & 2608,33 & 21,74 \\
\hline P 7 anos & 3391,67 & 6783,33 & 56,53 \\
\hline P 9 anos & 4116,67 & 8233,33 & 68,61 \\
\hline P 12 anos & 4737,50 & 9475,00 & 78,96 \\
\hline Car. 2 anos & 587,50 & 1175,00 & 9,79 \\
\hline Perda 10\% & $-75,00$ & $-150,00$ & $-1,25$ \\
\hline
\end{tabular}

\section{A) Avaliação dos Resultados}

A lucratividade da pupunha se mostrou mais sensível ao prazo de pagamento do empréstimo que às taxas de juros, e, mesmo no caso base, apresentou um excelente resultado, proporcionando uma renda mensal ao agricultor de mais de 20 salários mínimos, durante o período de amortização do empréstimo.

Estes resultados são ainda mais expressivos se os compararmos com a renda proporcionada pela soja, que no melhor dos casos é de 6,2 salários (Tabela 5.7). 
A produção da pupunha, com hipótese de perda sistemática de $10 \%$ da produção apresenta um resultado negativo de 1,25 salários por mês.

Estes resultados mostram que, a despeito da impossibilidade do agricultor conseguir um empréstimo desta monta, a cultura da pupunha tem um excelente resultado empresarial já no período de amortização do capital.

\subsection{Análise do Problema Isolado}

O problema isolado apresenta uma série de inconvenientes tanto para o produtor rural quanto para o empreendedor da $\mathrm{PCH}$.

Para a $\mathrm{PCH}$ existe o risco de retirada dos $30 \%$ de irrigação, o que inviabilizaria o retorno do capital investido. Desta forma, o que costuma acontecer é que, a PCH acaba incorrendo em custos maiores de capital para que se possa compensar o risco em que está inserida. Obviamente que, neste contexto, o investidor do setor energético não tem, e nem deve ter, interesse no desenvolvimento da irrigação na área de abrangência de seu reservatório.

Do lado do produtor rural tem-se uma situação ainda pior, pois este não tem recursos para modernizar sua produção e está à margem dos empréstimos bancários, que exigem garantias muito maiores que sua capacidade. Desse modo, perpetua-se a situação de baixo rendimento nas pequenas propriedades rurais (no nosso caso são em torno de $60 \%$ do total de propriedades) estimulando o êxodo rural e o declínio dos índices sociais, tanto no campo quanto na cidade. Esta lógica infeliz, em parte contribui para o setor elétrico, que pode considerar em seu planejamento, o risco de retirada e água como sendo mínimo, no período de retorno do capital investido na usina. 
O fato é que, a despeito da viabilidade do cultivo da pupunha, apresentado anteriormente, o caso anterior não é factível no paradigma atual e a única relação com a implantação da usina é a competição pelo uso da água, que pode encarecer o capital relativo à administração do risco deste tipo de investimento.

Este caso exemplifica a necessidade de uma abordagem integrada que busque a sinergia entre os componentes da infra-estrutura, com vistas ao desenvolvimento social e econômico da população e, ao mesmo tempo, o retorno do capital do setor privado de forma igualmente sustentável.

A seguir o mesmo caso será submetido à abordagem da Gestão Integrada de Recursos, para verificar-se a possibilidade da conciliação de tais interesses e a possível obtenção de vantagens à todos os envolvidos.

\subsection{O Problema Segundo a Gestão Integrada de Recursos}

Passa-se agora ao estudo do mesmo caso segundo os preceitos da GIR.

O estudo que se segue foi baseado em dados reais e tendências que têm sido apontadas. Mesmo assim, não foi dada muita importância para se garantir aderência rigorosa às leis e regulamentações vigentes, uma vez que o intuito do estudo é fixar os conceitos da GIR, que devem estar, o tanto quanto possível, acima de detalhes regulatórios ou circunstanciais (que sofrem muitas mudanças ao longo do tempo). Além disso, a própria GIR pode, em estudos mais avançados, servir de base para alterações institucionais. 
Os componentes da infra-estrutura escolhidos são a energia elétrica e a irrigação, sendo que a sinergia entre ambos se dá na utilização da água de um mesmo reservatório, só que para fins diferentes.

No caso isolado verificou-se a impossibilidade de um pequeno agricultor conseguir um empréstimo suficiente para implantação da cultura da pupunha.

Para a $\mathrm{PCH}$ o problema mais sério se referia à possibilidade de retirada de água do reservatório, o que inviabilizaria o empreendimento. Este é um caso limite, pois as médias e grandes usinas são menos sensíveis à retirada de água para irrigação, que, pela ordem de grandeza dos grandes e médios reservatórios, é de baixa probabilidade de ocorrência.

A seguir o problema passará a ser abordado segundo a Gestão Integrada de Recursos, sendo inicialmente realizada a Identificação dos Componentes.

\subsubsection{Identificação dos Componentes}

Neste caso, considera-se a PCH como sendo justificável por contar com um mercado consumidor economicamente atraente (uma vez que a região apresenta demanda reprimida) e, de acordo com o novo modelo do setor, contando com a participação privada no seu financiamento, construção e operação.

No entanto, deve-se lembrar que, de acordo com o Código de Águas, pode ocorrer, ao longo do tempo, a retirada de no máximo $30 \%$ da água para irrigação (vide Tabela 5.4). Neste caso, ou já se dimensiona uma menor 
capacidade de geração (incorrendo em perda de receita, caso a retirada não ocorra) ou deve haver um mecanismo para compensação da mesma.

A GIR deve considerar o problema da retirada de água, de forma a garantir o interesse do Setor Privado na construção e operação da PCH.

A irrigação, por outro lado, pode ser enquadrada como uma estrutura socialmente necessária e portanto deverá contar com a participação do Estado como ente financiador.

Entende-se que o capital necessário à alavancagem da atividade agrícola deva ser provido por órgãos (governamentais ou não) de fomento. Isto porque o desenvolvimento da agricultura é fundamental para a sustentabilidade de um país, e sua viabilidade vai muito além da econômica.

Ainda sobre essa participação, se tais órgãos considerassem o custo de oportunidade de seu capital, provavelmente não haveria o financiamento de nenhum tipo de atividade agrícola. O Estado não deve ser um investidor cujo lucro visado seja o máximo retorno do capital empregado, e sim o máximo retorno social e ambiental que este capital pode proporcionar.

Esta abordagem é comum inclusive nos países industrializados e de economia dita globalizada, que muitas vezes subsidiam (e outras tantas vezes adotam práticas protecionistas) a atividade agrícola local.

Por esses motivos é que se identificou como sendo necessária a atuação do setor público no financiamento do capital necessário à agricultura, evitando a sua inviabilização por concorrência (desnecessária e desequilibrada) com o capital especulativo, que apresenta altas taxas efetivas de juros, sem no entanto estar vinculado à qualquer atividade produtiva. 
Esta atuação visa garantir os empréstimos com taxas de juros e carências próprias ao desenvolvimento do setor agrícola e não ao ganho financeiro relacionado ao capital especulativo.

\subsubsection{A Nova Modelagem}

\subsubsection{Atividade Agrícola}

Para alterar as condições desfavoráveis à agricultura, será considerado o seguinte caso:

Será constituída uma área de 200 ha, composta por 5 pequenos produtores, portanto propriedades menores que 50 ha.

O sistema de irrigação será comprado por uma empresa privada de produção de palmito industrializado, e, ao final de 12 anos, o sistema deverá ser de propriedade dos agricultores.

Será composta uma sociedade onde os agricultores deverão entrar com a terra e o trabalho e a indústria de palmito com o sistema de irrigação.

O agricultor será remunerado segundo a lucratividade do caso base, ou seja, US\$212,00/ha/ano (vide Tabela 5.13).

A indústria terá seu investimento baseado segundo o caso de 9 anos para pagamento do empréstimo (vide Tabela 5.13).

A remuneração de cada agricultor será de acordo com a quantidade de terra plantada de sua propriedade e a duração da sociedade deverá ser de pelo menos 12 anos, que inclui os 9 anos do empréstimo mais 3 anos, após os quais o agricultor passa a ser o proprietário do sistema de irrigação. 
Essa diferença na divisão de lucros se deve ao fato de que é a indústria quem está assumindo o risco do empréstimo, que para o sistema de irrigação e compra das mudas é da ordem de US\$964.000,00.

Além disso, a diferença justifica que, ao final dos 12 anos, o sistema de irrigação passe a ser de propriedade do agricultor. Neste caso, a diferença ficaria como sendo o pagamento de um leasing por parte do agricultor, que estaria comprando o sistema.

Aqui podem-se identificar as seguintes atuações:

Estado: financiador da atividade agro-industrial.

Setor privado: empresa assume o empréstimo e o risco, viabilizando a construção do sistema de irrigação e a cultura da pupunha.

Agricultor: terá um acréscimo substancial na sua renda e contará com o sistema de irrigação ao final de 12 anos.

\subsubsection{Sustentabilidade no Uso da Água}

A sustentabilidade deve ser um dos objetivos da GIR, sendo assim, deverá ser analisada já durante a elaboração da proposta.

A utilização da água para irrigação é extremamente importante para o desenvolvimento de uma região, mas alguns aspectos devem ser analisados.

O Código Nacional de Águas estabelece que $30 \%$ do volume de água regularizada de um rio ou reservatório é para uso deste fim e que retiradas insignificantes não devem ser objeto de taxação. 
Se consideramos o benefício que a irrigação representará, é natural esperarmos que tais $30 \%$ sejam disponibilizados ao maior número possível de agricultores.

Caso contrário, criar-se-á uma elite irrigada, com seu direito adquirido sobre os $30 \%$, privando-se outros produtores do mesmo benefício.

A única forma de se garantir que o máximo de produtores tenha acesso a este recurso precioso é garantindo-se níveis mínimos de eficiência na irrigação.

Uma das formas para se atingir este objetivo é a polêmica cobrança no uso da água.

Em primeira instância pode parecer um imposto a mais ou um fardo para o agricultor, mas, do ponto de vista da sustentabilidade, é uma forma de incentivar o uso racional do recurso e ainda compensar pelo seu uso (vale lembrar que no futuro, quando os $30 \%$ ocorrerem haverá aqueles agricultores que não terão acesso à água, e não seria justo que os beneficiados não pagassem pelo seu uso).

Segundo a lei 9.433 de 8 de janeiro de 1997 (Cap. III, Art. 38), a cobrança pelo uso da água deve ficar a critério dos Comitês de Bacia e diz que é de competência dos Comitês, entre outros:

II - arbitrar, em primeira instância administrativa, os conflitos relacionados aos recursos hídricos;

V - propor ao Conselho Nacional e aos Conselhos Estaduais de Recursos Hídricos as acumulações, derivações, captações e lançamentos de 
pouca expressão, para efeito de isenção da obrigatoriedade de outorga de direitos de uso de recursos hídricos, de acordo com os domínios destes;

$\mathrm{VI}$ - estabelecer os mecanismos de cobrança pelo uso de recursos hídricos e sugerir os valores a serem cobrados;

IX - estabelecer critérios e promover o rateio de custo das obras de uso múltiplo, de interesse comum ou coletivo.

Para que fique claro o caráter participativo da sociedade nos Comitês, é descrita a composição de seus membros (segundo Art. 39 da mesma lei):

Representantes:

I - da União;

II - dos Estados e do Distrito Federal cujos territórios se situem, ainda que parcialmente, em suas respectivas áreas de atuação;

III - dos Municípios situados, no todo ou em parte, em sua área de atuação;

IV - dos usuários das águas de sua área de atuação;

V - das entidades civis de recursos hídricos com atuação comprovada na bacia.

$\S 1^{\circ} \mathrm{O}$ número de representantes de cada setor mencionado neste artigo, bem como os critérios para sua indicação, serão estabelecidos nos regimentos dos comitês, limitada a representação dos poderes executivos da União, Estados, Distrito Federal e Municípios à metade do total de membros. 
Esta composição mostra o caráter participativo da sociedade nas decisões do Comitê, que tem a atuação governamental limitada em no máximo $50 \%$.

Fica claro também que os Comitês podem estabelecer o critério de cobrança no uso da água e determinarem quem deve ser submetido à tal cobrança.

\section{A) Atuação dos Comitês de Bacia no Caso Proposto}

No nosso exemplo caberia ao Comitê regional a gestão do uso da água.

A gestão da água deve garantir que o maior número possível de agricultores tenha acesso à esta e ao mesmo tempo que haja interesse do setor privado na construção da usina.

Esta segunda parte pode parecer contraditória, mas a regularização do rio representa um aumento significativo da água disponível para irrigação.

No caso em questão, o rio regularizado em $18,6 \mathrm{~m}^{3} / \mathrm{s}$ contra os $14 \mathrm{~m}^{3} / \mathrm{s}$ (correspondentes à vazão mínima no período de estiagem) representa um acréscimo de $32 \%$ na água disponível, representando um ganho de 1,38 m³ para irrigação, justamente na época mais crítica para agricultura.

Neste contexto, a gestão da água deve considerar o valor deste aumento substancial da água disponível, e daí a necessidade de incentivos para que a usina seja construída.

Com o intuito de garantir o máximo de água para irrigação e ao mesmo tempo seu uso eficiente, seria estabelecido um valor para cobrança no uso pela irrigação, valor este que seria alocado para um fundo a cargo do comitê. 
A cobrança seria executada apenas após a primeira colheita, e o destino dos recursos do fundo estariam bem definidos à priori. A cobrança não pode incidir sobre a PCH, pois esta é isenta pela lei 9.433.

O Fundo teria como objetivos:

- Fornecer recursos para ampliação (criação de novos projetos) e eficientização da irrigação na área de atuação do Comitê de Bacia;

- Prover recursos para a compensação da usina, que será melhor detalhada adiante.

\section{B) A Cobrança da Água para Irrigação}

Para efeito deste estudo, será calculado o valor agregado à cada produto (energia elétrica e pupunha) por $\mathrm{m}^{3}$ de água utilizado. Sendo consideradas as utilizações: água turbinada pela usina e água usada na irrigação, sem a preocupação com as características diferenciadas de cada uso.

Essas características diferenciadas referem-se ao fato de que a água para irrigação é retirada do reservatório ou rio e é absorvida pela terra ou evaporada, representando perda imediata para o curso d'água.

A água turbinada na usina, por sua vez, não é retirada do curso, mas é imobilizada para outros usos, pois está reservada para geração (excetuados os usos para dessedentação animal e uso humano, que, via de regra, representam retiradas insignificantes). Além disso, a criação do reservatório acarreta diversos danos ambientais, conforme tratado no Capítulo 2. 
Sendo assim teremos:

$\underline{\mathrm{PCH}}$

No nosso caso, o valor da energia considerado foi de:

$1 \mathrm{MWh}=\mathrm{US} \$ 35,00$.

Como para gerar $1 \mathrm{MWh}$ são necessários $38.225 \mathrm{~m}^{3}$ (1 hora a 10,62 $\mathrm{m}^{3} / \mathrm{s}$, segundo equação 5.1 ), então:

"Valor Agregado pela Energia Elétrica à Água" $\Rightarrow$ US $\$ 0,0009 / \mathrm{m}^{3}$.

Pupunha

Será considerado o valor bruto de venda, que é de US\$ 2.300/ha/ano (Tabela 5.13) para 6.932,43 $\mathrm{m}^{3} /$ ha (Tabela 5.11).

"Valor Agregado pela Pupunha à Água" $\Rightarrow$ US $\$ 0,33 / \mathrm{m}^{3}$.

Estes dois valores mostram bem a diferença de valores agregados por um e outro uso, e fica evidente que, embora a agricultura retire parte da água, esta agrega muitas vezes mais valor por $\mathrm{m}^{3}$ utilizado.

Um valor que tem sido cogitado para cobrança no uso da água é de $R \$$ $0,01 / \mathrm{m}^{3}$ [Ref. 17], que corresponde a US $\$ 0,005 / \mathrm{m}^{3}$.

Este valor corresponderia a $16 \%$ do valor agregado líquido pela pupunha à cada $\mathrm{m}^{3}$ e não se pode dizer que não seria significativo. $O$ valor agregado líquido se refere à lucratividade, segundo o caso base, durante a amortização do empréstimo, que é de US $\$ 212,00 /$ ha/ano, e representa US $\$$ $0,03 / \mathrm{m}^{3}$. 
Sob a ótica da aceitabilidade, tal cobrança deveria corresponder à redução de outros encargos.

Por outro lado deve haver cobrança para que haja sustentabilidade.

Aqui depara-se novamente com a problemática da Aceitabilidade versus Sustentabilidade. Se a cobrança da água fosse realmente compensada com a redução equivalente de tributos, certamente ela seria mais aceitável. Além disso, dada a composição heterogênea dos Comitês, o processo para estabelecimento da cobrança da água torna-se mais democrático e participativo, pois conta diretamente com o envolvimento dos afetados.

Este caráter participativo está de acordo com os preceitos da aceitabilidade, discutidos no Capítulo 3. A aceitação desta cobrança só acontecerá no caso em que fique bem claros seus objetivos e benefícios, e isto só deve acontecer caso haja um processo de debate aberto. Além disso, tal processo deve ser precedido de uma etapa de conscientização e educação dos envolvidos.

Para efeito deste exemplo, o valor cobrado será reduzido à US\$ 0,003 ou $10 \%$ do valor agregado líquido da pupunha.

Este valor não é significativamente alto para esta cultura, que possui um alto valor agregado por $\mathrm{m}^{3}$ de água utilizada. Por outro lado, o valor da água não poderá deixar de ponderar o valor de outras culturas, bem como estudos constantes de mercado e viabilidade das safras, de modo a não se penalizar o cultivo de outros produtos. O valor da cobrança não deve comprometer 0 desempenho de mercado das culturas que façam uso da irrigação, mas 
também não deve ser tão baixo a ponto de que uma cultura de pouco valor agregado e muita utilização de água seja beneficiada (sustentabilidade).

Deste valor, $30 \%$ será reservado para a gestão da problemática referente à usina, conforme será visto a seguir.

\subsubsection{Compensação à $P C H$}

Para que haja viabilidade da $\mathrm{PCH}$ é necessário que não haja a retirada dos $30 \%$ para irrigação, ou mesmo que seja criado um mecanismo para compensá-la. Conforme mencionado, este é um caso limite para a geração de energia elétrica, pois, via de regra, as usinas têm sua viabilidade garantida quase que independentemente da irrigação.

Na gestão do recurso hídrico é necessário que haja a construção da barragem, viabilizada inicialmente pela usina, pois, conforme já mencionado, sua construção aumentará sensivelmente a disponibilidade de água para irrigação, além dos outros usos.

Embora entenda-se aqui que a usina não é proprietária do reservatório, somente tem o direito de utilização da água para geração, sua presença foi vista, neste exemplo, como necessária para o financiamento da barragem, que de outra maneira teria poucas chances de ser construída. Dessa forma, embora a $\mathrm{PCH}$ não seja proprietária do reservatório, é ela, em primeira instância, quem vai justificar financeiramente a sua construção. 
Dessa forma, para este exemplo será proposto um mecanismo que compense a usina de possíveis retiradas de água para irrigação, desde que venham a ocorrer no intervalo de recuperação do capital da mesma.

Para tanto, o período de recuperação considerado seria de 25 anos.

Para que esta situação ocorra é necessário um empréstimo à usina à taxa de $8 \%$ ao ano.

Novamente o Estado deverá participar do processo, desta vez não como financiador mas como facilitador de um empréstimo internacional para o projeto. Esta figura do facilitador se daria através do Estado intervindo em favor da empresa para obtenção de um empréstimo internacional, sob a justificativa de que se trata de um projeto voltado ao desenvolvimento de uma região carente. Mecanismos análogos têm sido implementados para a viabilização de termelétricas a gás natural, onde a Eletrobrás (empresa estatal) garante a compra de gás, caso não seja usado para geração de energia elétrica. Trata-se de uma aliança estratégica, sem a formação de uma sociedade, que, dentro das regras de mercado, garante a viabilização de um empreendimento, no caso, o gasoduto. Analogamente, o Estado poderia fornecer a garantia de compra da energia elétrica proveniente da $\mathrm{PCH}$.

A compensação à usina se dará com $30 \%$ do valor do Fundo, que corresponde, aproximadamente, ao valor agregado pela energia elétrica para cada $\mathrm{m}^{3}$ turbinado.

Assim, a cada $1 \%$ de retirada de água no período de 25 anos será pago o valor de US $\$ 0,001 / \mathrm{m}^{3}$ para usina, multiplicado pelo fator de compensação descrito a seguir. 


\section{A) Fator de Compensação à Usina}

Para que haja a retirada de água é necessário o consumo de energia elétrica para bombeamento. Assim sendo, ao mesmo tempo em que há a perda relativa à retirada de água, há, paralelamente, um benefício associado à venda de energia elétrica pela usina.

Segundo esta lógica, a usina pode até se interessar pela ocorrência de índices baixos de eficiência elétrica, pois estaria vendendo mais energia para cada metro cúbico de água retirado do reservatório.

Para que isto não ocorra, será sugerido um índice simplificado (k) de perda para usina, baseado também na eficiência da irrigação, conforme se segue:

$\mathrm{K}_{\text {usina: }}:\left[\mathrm{kWh} / \mathrm{m}^{3}\right]$,

ou seja: $\mathrm{kWh}$ gerados por $\mathrm{m}^{3}$ turbinado na usina.

$\mathrm{K}$ irrigação: $\left[\mathrm{kWh} / \mathrm{m}^{3}\right]$,

ou seja: $\mathrm{kWh}$ gastos por $\mathrm{m}^{3}$ bombeado para irrigação.

A partir destes dois índices definiu-se o fator de compensação da usina:

$$
\mathrm{FC}=\frac{\mathrm{K}_{\text {usina }}}{\mathrm{K}_{\text {irrigação }}}
$$

Para o nosso exemplo temos:

$\mathrm{K}_{\text {usina }}: 0,26958 \mathrm{kWh} / \mathrm{m}^{3}$ gerados.

$\mathrm{K}_{\text {irrigação: }}: 0,3248 \mathrm{kWh} / \mathrm{m}^{3}$ gastos. 
Ou seja, para cada $\mathrm{m}^{3}$ utilizado na irrigação, a PCH deixou de gerar $0,26958 \mathrm{kWh}$, mas vendeu outros $0,3248 \mathrm{kWh}$.

Dessa maneira, o Fator de Compensação $(\mathrm{Fc})$ da usina será:

$\Rightarrow F c=\frac{0,26958}{0,3248}=0,83 \%$

que é o que a usina realmente perde com a irrigação.

A partir deste valor, a compensação do montante de água retirado da usina deverá ser corrigido de acordo com este valor, sendo tanto menor a compensação quanto menor for a eficiência energética da irrigação pois a usina já está sendo compensada com maior venda de energia.

Por outro lado se a usina quiser uma maior compensação deverá investir em eficiência, seja na sua própria geração (que aumentaria a parcela $\mathrm{K}_{u s i n a}$ ), seja na irrigação através de equipamentos mais eficientes (o que diminuiria

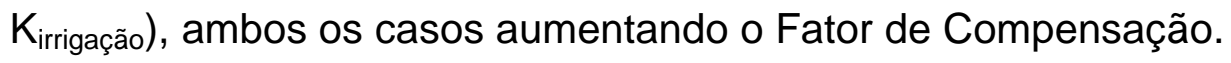

Tal eficiência poderia se dar através de equipamentos que utilizem rotação variável [Ref. 6 e 7], tanto na geração como no bombeamento, e que poderiam ser alugados, vendidos, financiados ou fornecidos através de leasing para os agricultores, que por sua vez teriam como benefício a redução na conta de energia elétrica.

Um aspecto a se ressaltar é o de que o fator não considera o custo marginal de produção de energia elétrica pela usina. Dessa forma, uma outra maneira da usina obter um melhor desempenho em relação à irrigação seria o uso de técnicas de Gerenciamento pelo Lado da Demanda - GLD [Ref. 30]. Ou seja, atuar nos usos finais da energia elétrica (consumidores), de modo a 
alterar o seu horário de uso para outro onde o custo marginal de produção da usina é menor. Um exemplo seria a utilização de descontos especiais na tarifa de energia elétrica para os agricultores que utilizarem seus sistemas de irrigação em horários menos críticos para o setor elétrico. Estes descontos poderiam ser dados em acordo com a concessionária local, já que para comprar energia elétrica diretamente de uma $\mathrm{PCH}$ é necessário ter uma potência instalada da ordem de $500 \mathrm{~kW}$.

Em outra etapa de desenvolvimento do projeto devem-se estabelecer padrões de eficiência no consumo de água/ha/tipo de cultura. A partir daí o fator de compensação poderia considerar ações como por exemplo a mudança de técnica de irrigação para obter redução no consumo de água, mas sem se desobrigar da eficiência elétrica.

Ainda em um grau de desenvolvimento mais adiantado, a tarifa pelo uso da água poderia ser alterada de acordo com o nível de eficiência energético do sistema de irrigação e ainda de acordo com a quantidade de água utilizada por área plantada.

Este fator tem como objetivo garantir o interesse da usina na eficiência energética da irrigação, para que haja um fluxo de capital (resultado de análises econômicas da $\mathrm{PCH}$ ) para a eficiência energética no âmbito rural (geralmente descapitalizado).

Ainda sobre esta compensação pode-se considerar que o risco de retiradas é baixo, pois, para que ocorra a retirada dos 30\%, são necessários investimentos da ordem de US\$184 milhões correspondentes à sistemas de 
irrigação para 3.800 ha, que é a área passível de irrigação com este montante de água.

Dessa forma, garante-se 0 interesse do setor privado na usina e assume-se um risco reduzido para tal. A ocorrência da retirada seria inclusive o melhor caso, dado o montante de valor agregado à agricultura da região e ao fundo do Comitê de Bacia (2/3 vão para novos projetos).

A retirada total dos $30 \%$ representaria US $\$ 527.912,00 /$ ano para o fundo dos quais US $\$ 158.373,00 \times 0,83$ iriam para usina, perfazendo um total de US\$ 131.450,00. Aqui nota-se a importância do Fator de compensação, que reduziu em US\$26.923,00 a compensação à usina. Este valor mostra como ações de eficientização poderiam afetar diretamente o faturamento da usina, no caso da compensação ocorrer.

Após o período de 25 anos o comitê estaria desobrigado da compensação à usina e todo o valor seria revertido para ações visando a irrigação.

De acordo com o até agora exposto tem-se:

> Infra-estrutura: energia elétrica e irrigação;

> Componente economicamente viável: $\mathrm{PCH}$;

> Componente socialmente necessário: Irrigação;

Participação no processo:

População Carente: pequenos agricultores com 5 propriedades: 200 ha;

Setor privado: $\mathrm{PCH}$; Indústria de palmito; 
Setor público: Estado: financiador para agricultura e facilitador para $\mathrm{PCH}$;

Regulador: Comitê de Bacia, submetido às normas da Agência Nacional de Águas - ANA: cobrança do uso da água com vistas à sustentabilidade.

\subsubsection{Análise das Vantagens}

\subsubsection{Análise das Vantagens Econômicas}

\section{A) Pupunha}

O novo modelo altera drasticamente o panorama do cultivo da pupunha.

É realizada uma espécie de arrendamento da terra, onde o agricultor, além da terra, entra com o trabalho e toda a realização da cultura.

A indústria de palmito investirá no sistema de irrigação e mudas de pupunha, ficando com a responsabilidade do empréstimo discutido anteriormente.

Por se tratar de uma indústria, o crédito é mais facilmente liberado, até porque ela em si garante a compra da produção e possui uma maior capacidade de endividamento.

Nesse modelo, o empréstimo será com prazo de 9 anos (esta modalidade de empréstimo tem prazos de até 12 anos) e taxa efetiva de juros de $8,75 \%$ ao ano (vide Tabela 5.11), conforme o modelo EGF (Empréstimo do governo Federal). 
O agricultor será remunerado segundo o caso base (6 anos) e receberá US\$212/ha/ano, ou seja, o lucro que ele teria caso tivesse acesso ao crédito necessário (vide Tabela 5.11).

A indústria, por estar operando em um prazo alongado em relação ao base, teria uma lucratividade de US\$ 988,00/ha/ano (vide Tabela 5.11), descontando-se o valor a ser pago aos agricultores então a lucratividade real será de US\$776,00/ha/ano.

Com a cobrança do uso da água, prevista neste modelo teríamos:

Consumo de água (tabela 5.11): $6.933 \mathrm{~m}^{3} / \mathrm{ha} / \mathrm{ano}$.

Valor a ser pago: US $\$ 0,003 / \mathrm{m}^{3}$.

Logo: US $\$ 20,8 /$ ha/ano.

De onde a nova lucratividade da empresa será de US\$755,5/ha/ano.

Como o interesse da indústria é beneficiar o palmito, esta lucratividade pode ser vista pela mesma como redução nos custos de matéria prima, que no caso é a pupunha in natura.

Este exemplo não tem como objetivo analisar a viabilidade desta indústria, mas, apenas como referência, apresentam-se os seguintes dados relativos à pupunha:

Produto in natura: US $\$ 0,58 / \mathrm{kg}$.

Produto envasado (média): US\$ 5,25/kg para o envasamento em vidro de $300 \mathrm{~g}$.

Pode-se verificar que o valor agregado ao produto in natura é da ordem 
de 9 vezes, sendo que se trata de um processo de beneficiamento relativamente simples [Ref. 41].

Como no novo modelo a empresa passa a contar com uma redução de US\$ $755 /$ ha ou US\$ 755/4000 kg o novo preço de custo do produto in natura passa de US\$ 0,58 para US\$ 0,39/kg, mostrando a vantagem para a indústria, que se beneficiará de uma redução de 32\% no valor da matéria prima.

Após a recuperação do capital, este sistema permitirá aumentar o ganho do agricultor e reduzir ainda mais os custos para a indústria.

Segundo os valores da Tabela 5.13, o volume total do capital movimentado pela indústria de palmito, para 200 ha, é de US\$4.160.000,00. O valor movimentado pela pupunha in natura é de US\$309.000,00. Este valor já está descontado do lucro da empresa de palmito, que tem este lucro creditado como redução no valor a se pagar pela pupunha. Ou seja, somente a viabilização do cultivo e industrialização do palmito trará à região a quantia aproximada de US\$ 4.470.000,00, sem se considerar o efeito multiplicador desta atividade sobre os outros setores da economia local.

\section{B) $\mathrm{PCH}$}

Para a $\mathrm{PCH}$ o risco relativo à retirada de água fica compensado através dos recursos do fundo. Para este exemplo, foi considerada a possibilidade de compensação a partir de $1 \%$ de retirada de água.

O Comitê de Bacia terá a incumbência de complementar o rendimento da usina através dos recursos do fundo, para montantes de retiradas a serem definidos, de acordo com as regras fixadas pela regulação vigente e pelo contrato de concessão. 
O período de recuperação será de 25 anos, através da obtenção do empréstimo internacional a $8 \%$ ao ano (vide Tabela 5.6).

Dessa forma, o maior risco da $\mathrm{PCH}$ fica reduzido à $5 \%$ em 25 anos, que é o novo período de recuperação do capital e sua viabilidade e atratividade econômica ficam garantidas ao setor privado.

O valor bruto de capital gerado pela $\mathrm{PCH}$ é calculado a seguir.

Para um fator de carga de 70\% (baseado na operação de uma usina semelhante da região [Ref. 22]), tem-se:

Energia Elétrica anual: $15.330 \mathrm{MWh}$.

Para a tarifa de US\$ 35,00 / MWh, então:

A PCH deverá agregar um valor bruto anual à região de US\$ $536.550,00$.

\subsubsection{Análise das Vantagens Sociais}

Socialmente, a GIR traz o benefício imediato da facilitação da implantação da $\mathrm{PCH}$ e do cultivo da pupunha. Considerando-se que, para ambos os casos, há mercado comprador (ambos com demanda reprimida).

Sem estes, a situação de pouco desenvolvimento, falta de infraestrutura, pequenos agricultores e êxodo rural se manteria.

Neste caso, o maior impacto, do ponto de vista social, é justamente a falta de acesso à infra-estrutura e desenvolvimento, conseqüentes da não disponibilidade de atividades produtivas que permitam o afluxo de capital para 
a região.

Para que se possam avaliar os resultados da implantação do projeto, são dadas a seguir algumas das características relativas ao município de Cruzália, que serviu de base para este exemplo. Em seguida, serão descritas conseqüências desta proposta para o Setor Público e para a População.

\section{A) Características Sociais do Município de Cruzália}

$\mathrm{Na}$ tabela 5.15 a seguir tem-se algumas das características físicas e sociais do município de Cruzália.

Tabela 5.15: Características Físicas e Sociais do Município de Cruzália

\begin{tabular}{|l|c|c|c|}
\hline & CRUZÁLIA & Região & $\begin{array}{c}\text { Ano de } \\
\text { Referência }\end{array}$ \\
\hline Área & 122 km² $^{2}$ & --- & -- \\
\hline População & $3153^{*}$ (habitantes) & $233.238^{*}$ & 1999 \\
\hline Taxa de Natalidade & 13,71 (por mil habitantes) & 19,4 & 1993 \\
\hline Taxa de Mortalidade & 5,19 (por mil habitantes) & 6,87 & 1993 \\
\hline Evasão Escolar $\mathbf{1}^{\circ}$ grau & 13,17 (por mil habitantes) & 13,45 & 1990 \\
\hline Evasão Escolar $\mathbf{2}^{\circ}$ grau & 20,88 (por mil habitantes) & 22,06 & 1990 \\
\hline PIB per capita (média da região) & $1.890^{* *}$ (US\$/habitante) & $1890^{* *}$ & 1990 \\
\hline
\end{tabular}

* Estimativa

** Valor inferido através do indicador de Intensidade de EE (relativo a São Paulo) e relacionado ao investimento per capita da região

1- Fonte: (Fukuda,[Ref. 23], AEDAS [Ref. 34]

Nota-se que o município apresenta índices melhores que a média da região, com menores taxas de mortalidade, natalidade e evasão escolar.

Mesmo assim, os valores destes índices ainda são altos, especialmente a evasão escolar, que tem apresentado crescimento em seus índices [Ref. 34]. 


\section{B) Impactos no Setor Público}

\section{B1) Prefeituras}

As Prefeituras locais teriam um aumento significativo na arrecadação de impostos, através da produção da pupunha e sua industrialização, além da geração de energia elétrica.

Como exemplo da importância que um projeto destes tipo representaria, há caso da prefeitura de São Tomé, no estado do Paraná. A Prefeitura da cidade criou, como opção de incrementar a renda dos produtores rurais do município, o Projeto Pupunha, o Palmito Ecológico de São Tomé, [Ref. 36] que tem como meta o incentivo para plantação de 4 milhões de pés de pupunha. Estima-se que tal quantidade seja responsável pela injeção anual de $\mathrm{R} \$ 6$ milhões na economia local.

O Município será beneficiado com o aumento na arrecadação de impostos, e o comércio através do aumento do consumo interno decorrente da circulação de moeda na comunidade local. Com o projeto serão beneficiados 60 agricultores, em uma área de 800 ha. A indústria de palmito instalada na região já gerou 20 empregos diretos em sua unidade produtiva, além dos empregos gerados no meio rural.

Como incentivo à produção, a Prefeitura Municipal de São Tomé está subsidiando as mudas comercializadas na região que passaram de $R \$ 0,50$ para $R \$ 0,22$, o que altera bastante o custo inicial do investimento na cultura.

No nosso exemplo, para 200 ha, haveria uma redução de US $\$ 90.000,00$ no custo inicial de implantação da cultura, o que mostra que os benefícios para região são consideráveis a ponto de justificar tal incentivo. 
Um exemplo de arrecadação direta pela prefeitura é a cobrança do ISS, que incide sobre a produção e comércio locais, além de incidir nos rendimentos de profissionais autônomos.

\section{B2) Governo Estadual}

O Governo Estadual, embora isente a pupunha in natura da cobrança do ICMS, terá benefícios com a cobrança deste imposto na venda do palmito industrializado, que, para efeito deste estudo foi suposta como sendo de $7 \%$ (que é a menor alíquota de ICMS no Estado de São Paulo).

Além disso, há a cobrança sobre a venda de energia elétrica ao consumidor final, com alíquotas que variam de 0 (consumidores de baixa renda) até $25 \%$.

\section{B3) Governo Federal}

O Governo Federal, que participou como financiador, teria por sua vez maior arrecadação em impostos e seria igualmente beneficiado pela implantação do projeto, pois, tanto a implantação da $\mathrm{PCH}$ como da agroindústria de palmito, representam rendas e arrecadações anteriormente inexistentes.

Para melhor exemplificar os ganhos do Setor Público, será estimado o valor da arrecadação anual de impostos, considerando-se apenas os que incidem sobre o valor bruto dos produtos. A pupunha in natura não será considerada nesta estimativa, pois sua produção vem recebendo incentivos fiscais de diversas naturezas. 
Para a prefeitura, será considerada a cobrança de ISS, suposto como sendo de $1 \%$ para o palmito industrializado, no município de Cruzália.

Para o governo do Estado, serão consideradas as alíquotas de 12,5\% para energia elétrica e $7 \%$ para o palmito industrializado.

Para o governo Federal, será considerada a cobrança dos impostos sobre o faturamento bruto:

Cofins: $2 \%$

$>$ PIS-PASEP: $0,65 \%$

> Contribuição Social: 12\%.

Perfazendo um percentual total de $14,65 \%$ do faturamento bruto.

Os faturamentos anuais de acordo com as atividades foram calculados a seguir.

\section{B4) PCH}

Faturamento da $\mathrm{PCH}$ : US $\$ 536.550,00$.

Para o cálculo do ICMS este valor é subestimado, pois este imposto aplica-se sobre a tarifa de venda de energia elétrica para o consumidor final, que no caso residencial pode chegar a mais de US $\$ 60,00 / \mathrm{MWh}$.

\section{B5) Palmito Industrializado}

Conforme já calculado, o valor bruto anual é de: US\$4.160.000,00.

A partir destes valores construiu-se a Tabela 5.16 a seguir. 
Tabela 5.16: Estimativa de Arrecadação de Impostos

\begin{tabular}{|l|c|c|c|c|}
\hline ATIVIDADE & $\begin{array}{c}\text { Prefeitura } \\
\text { ISS } \\
\text { (US\$) }\end{array}$ & $\begin{array}{c}\text { Estado } \\
\text { ICMS } \\
\text { (US\$) }\end{array}$ & $\begin{array}{c}\text { Gov. Federal } \\
\text { Cofins - PIS - Cont. Social } \\
\text { (US\$) }\end{array}$ & $\begin{array}{c}\text { Setor } \\
\text { Público }\end{array}$ \\
\hline PCH & --- & 67.069 & 78.603 & 99.700 \\
\hline Palmito Ind. & 41.600 & 291.200 & 609.440 & 942.240 \\
\hline TOTAL & $\mathbf{4 1 . 6 0 0}$ & $\mathbf{3 5 8 . 2 6 9}$ & $\mathbf{6 8 8 . 0 4 3}$ & $\mathbf{1 . 0 4 6 . 3 1 2}$ \\
\hline
\end{tabular}

Estes valores mostram o quanto é significativa a arrecadação proveniente da implantação do projeto.

Para efeito de avaliação de benefícios, pode-se destacar o caso do Governo Federal, que foi o financiador da cultura da pupunha, com juros de $8,75 \%$ aa. A parcela relativa à amortização anual da dívida mais juros é de US\$ $180.400,00$ e, em princípio poderia parecer que o governo estaria incorrendo em prejuízo financeiro. A Tabela 5.16 mostra que o ganho com impostos (na realidade apenas parte deles) é 3,6 vezes superior à amortização do capital e mostra que há também, além do social e ambiental, benefício financeiro para 0 governo. Se somarmos os valores de arrecadação mais a parcela do empréstimo teremos US\$ 868.444,00, que corresponde à $90,40 \%$ do montante total do empréstimo concedido. Obviamente que isto acontece por efeito da implantação da indústria de palmito com capital privado, mas, em uma análise mais ampla, como neste caso, estes resultados são parâmetros válidos, pois a indústria não teria se instalado na região caso a pupunha não tivesse sido viabilizada pelo empréstimo.

Este tipo de atuação do Setor Público, é justamente a proposta da GIR, pois o Estado alavancou a atividade agrícola através de financiamento e, ao 
mesmo tempo, permitiu, através da regulação, a integração do Setor Privado ao empreendimento, garantindo a provisão de infra-estrutura (Energia Elétrica e o sistema de Irrigação).

Além dos impostos considerados, há ainda o Imposto de Renda, tanto das empresas quanto dos trabalhadores, o ISS da prefeitura sobre os rendimentos do comércio e de profissionais autônomos, bem como os impostos que incidem sobre outros setores que acabam alavancados pela atividade e circulação de capital, decorrentes do efeito multiplicador, explicado no item 4.3.2.2.

\section{C) Comitê de Bacia}

A implementação do projeto prevê uma área de 200 ha e como a cobrança da água por ha é de US $\$ 20,80$, correspondentes ao consumo de $6.932 \mathrm{~m}^{3}$, anualmente serão arrecadados US\$ 4.160,00 correspondentes à uma retirada de água da ordem de $1.386 .400 \mathrm{~m}^{3} / \mathrm{ano}$.

Este montante corresponde à $0,24 \%$ do volume do rio (que para o período de 1 ano apresenta um volume de 586.569.600 $\mathrm{m}^{3}$ ) e, neste exemplo, não implicaria em compensação à usina, que só deveria ocorrer em 1\%.

A cobrança deverá ser efetuada sobre outros produtos que se utilizem da irrigação da mesma forma que este, mas deverá resguardar os pequenos agricultores, que necessitarão de ajuda para implantação e eficientização de seus rudimentares sistemas de irrigação, sendo este justamente o objetivo principal do Fundo. 
Pretende-se assim incentivar a racionalização do uso para esta finalidade e garantir o acesso de outros produtores, com a aplicação dos recursos arrecadados.

Apenas a título de exemplo, uma possibilidade interessante a respeito da gestão da água é o da usina abrir mão de sua parte para geração. Esta possibilidade seria interessante em um futuro onde a retirada dos $30 \%$ já teria se concretizado.

Através da cobrança do Comitê a usina poderia abrir parte de sua quota para irrigação e seria recompensada por isso.

Vale lembrar que o valor US\$ 0,003 é 3,33 vezes superior aos US\$ $0,0009 / m^{3}$ conseguidos com a geração.

Dessa maneira, o Comitê poderia gerenciar o uso da água de forma a garantir o maior uso para irrigação e, ao mesmo tempo, maior lucratividade para usina e maior valor agregado para região, sem no entanto abrir mão da sustentabilidade do projeto. Este exemplo parte da premissa que, no futuro, a geração de energia elétrica (no montante deste exemplo) será apenas um detalhe se comparada aos benefícios (econômicos e sociais) advindos do desenvolvimento da agricultura. Dessa forma, o uso da água passaria a ser priorizado para uma atividade de maior valor agregado por $\mathrm{m}^{3}$ de água utilizado e que geraria maior riqueza na região.

\section{D) Impactos na População}

Para a sociedade haverá ganhos como a geração direta e indireta de empregos (associados à $\mathrm{PCH}$, beneficiamento do palmito, área rural, manutenção, etc.) e todo o efeito multiplicador proveniente das duas atividades. 
Além disso, a maior arrecadação de impostos pelo Setor Público, deverá reverter-se em benefício da sociedade e portanto de toda a comunidade local. Espera-se com isto a melhora nas condições de ensino e saúde, bem como de toda a infra-estrutura da região.

Outro fator é o aumento do PIB per capita da cidade. Conforme a Tabela 5.1, o valor do PIB per capita médio da região é de US\$1.890,00. Com a implantação do projeto, haverá uma injeção de US\$ 5.005.550,00 na economia local. Fazendo-se o novo rateio pela população, que é de 3150 habitantes, o novo PIB per capita passa a ser de US\$3.479,00, ou seja, $84 \%$ maior.

Levando-se em conta que o IDH, descrito no item 4.3.2.1, é composto, com peso de um terço, pelo PIB local, haverá uma melhora considerável neste índice, que é considerado um bom parâmetro do desenvolvimento social.

Considerando-se ainda, novos investimentos em infra-estrutura que poderiam ser efetuados, mediante o aumento da arrecadação de impostos, é provável também que tanto na saúde (expectativa de vida) como na educação (grau de instrução) haja melhoras significativas, melhorando ainda mais o IDH local.

Um efeito importante a se destacar é a redução na utilização de agrotóxicos, decorrente do cultivo da pupunha. Esta redução está melhor explicada no item 5.6.3.3, mas sabe-se que deverá ocorrer a redução de pessoas contaminadas por estes elementos, especialmente os trabalhadores rurais. Este fato deve ser considerado como um fator de melhora na saúde e na condição de vida dessas pessoas. 
Ressalta-se que no cálculo do PIB per capita não foram incluídos os montantes de capital investidos para execução do projeto, que são volumes altos de capital e igualmente importantes para a economia da região.

Além destes, espera-se obter ganhos sociais como a fixação do homem no campo, conseqüência dos maiores salários e da presença de infra-estrutura básica, como a energia elétrica e a possibilidade de exploração de atividades econômicas conseqüentes da construção do lago, como pesca, recreação etc.

\subsubsection{Análise das Vantagens Ambientais}

\section{A) Mudança de Cultura de Soja para Pupunha}

Como no nosso exemplo houve mudança de cultura, de soja para pupunha, é necessário verificar-se se houve vantagens ou desvantagens ambientais, que deverão ser analisadas.

Para isso será analisado a seguir a influência de cada cultura no meio ambiente.

\section{A1) Impactos Ambientais do Cultivo da Soja}

Além dos problemas apontados no item 2.2.1, um dos impactos mais nocivos da agricultura para o meio ambiente é a erosão dos solos.

O preparo da terra (aragem e gradagem), necessário ao cultivo de grãos, é um dos principais causadores da erosão.

Além disso, a aragem provoca perda de carbono pela terra, e, em escala mundial, representa uma liberação de $\mathrm{CO}_{2}$ superior às emissões mundiais pela queima de combustíveis fósseis, segundo relatório do PNUD [Ref. 31]. 
Segundo o mesmo relatório, estima-se que para cada tonelada de grãos produzida no Brasil, dez toneladas de terra fértil são perdidas, carregadas pelas chuvas.

O Instituto Agronômico de São Paulo, analisou a perda de solo de diversas lavouras, e dentre elas, a soja apresentou uma perda de 20,1 t/ha/ano [Ref. 31], o que é uma perda alarmante.

Dessa maneira verifica-se que o cultivo da soja requer cuidados minuciosos no tratamento da terra que muitas vezes são deixados de lado, principalmente pelos pequenos agricultores (que compõem este estudo de caso).

Outro aspecto a ser ressaltado é o relativo ao uso de agrotóxicos.

Segundo dados do PNUD [Ref. 31], é no plantio da soja que se concentra a maior parte dos investimentos brasileiros em agrotóxicos, com $35 \%$ do mercado nacional (estimado em US\$ 2,2 bilhões anuais), ficando a cana-de-açúcar em segundo lugar.

O plantio direto, utilizado na região do Médio Paranapanema, é uma técnica de cultivo que reduz a erosão, mas necessita de uma quantidade elevada de herbicidas.

Além disso, os agrotóxicos têm sido aplicados em doses exageradas, principalmente em propriedades cuja lavoura não conta com o acompanhamento de um agrônomo (novamente os pequenos agricultores).

Como conseqüência do uso indiscriminado de agrotóxicos tem-se: 
- Intoxicação dos trabalhadores rurais (estima-se que, só em 1993, 300.000 pessoas tenham sido intoxicadas por agrotóxicos [Ref. 31]);

- Contaminação de recursos hídricos;

- Contaminação dos solos;

- Contaminação de cadeias alimentares (animais, os próprios alimentos, e o homem);

- Aumento do número de pragas resistentes aos agrotóxicos (mais de 400 novas pragas em menos de 20 anos);

\section{A2) Impactos Ambientais do Cultivo da Pupunha}

A cultura da pupunha possui características muito diferenciadas das da soja.

Como o seu crescimento (e consequentemente a sua colheita), é desuniforme, há sempre cobertura vegetal protegendo o solo quanto à erosão, tanto pelo efeito das chuvas (ou irrigação) como dos ventos.

Além desta cobertura vegetal densa, há a incorporação pelo solo da matéria orgânica excedente da planta, que não é utilizada comercialmente. Isto melhora as condições químicas, físicas e biológicas do solo, podendo até regenerar áreas degradadas e/ou de baixa fertilidade [Ref. 36].

Outro fator de extrema importância é que o cultivo da pupunha não requer a utilização de agrotóxicos, sendo este um diferencial fortemente positivo em relação não só ao cultivo da soja, mas de muitas outras culturas.

Além destes aspectos, a cultura da pupunha representa o cultivo sustentável do palmito, sendo chamada de "palmito ecológico". 
Isto se deve ao fato de que anteriormente o palmito era basicamente extraído da palmeira juçara (Enterpe Edulis), planta nativa da Mata Atlântica.

Cada pé de juçara leva em média 20 anos para chegar à idade adulta. Para produzir um palmito de $400 \mathrm{~g}$ a palmeira juçara leva 10 anos, enquanto que a pupunha necessita de apenas 1 ano para produzir a mesma quantidade.

A produção de palmito esteve, e ainda está, baseada no extrativismo predatório da juçara, o que representa a extinção da mesma no longo prazo.

O IBAMA proibiu o extrativismo da juçara, nativa da Mata Atlântica, mas a pobreza da população que vive em torno da mata faz com que o único modo de sobrevivência das famílias seja tal extração.

Algumas empresas têm-se valido deste fato e compram boa parte de seu palmito destas pessoas. Além disso, muitas fábricas de palmito registradas no IBAMA compram palmito clandestino juntamente com aquele produzido legalmente [Ref. 31].

Esta é uma prática proibida e predatória que está levando a palmeira juçara à extinção, o que tem efeitos danosos também à fauna que se alimenta desta espécie.

Um exemplo deste fato é o estado do Paraná, que nas décadas de 40 e 50 foi o maior produtor nacional de palmito juçara, atingindo praticamente $100 \%$ da produção nacional. Atualmente o Estado participa com apenas $0,1 \%$ do palmito consumido, evidenciando-se que, nos últimos 30 anos, o palmito nativo paranaense foi praticamente extinto [Ref. 36]. 
Outro aspecto não menos importante do extrativismo ilegal do palmito é o do risco à saúde dos consumidores, que muitas vezes compram palmito de origem clandestina, processado sem condições mínimas de higiene, o que pode causar botulismo, intoxicação que pode levar à morte.

O cultivo da pupunha, além dos benefícios apresentados, representa a alternativa sustentável à prática extrativista predatória, sendo por isto, a alternativa ambientalmente preferível.

Além do extrativismo predatório da palmeira juçara, outra espécie que tem sido extraída é a palmeira de açaí (Euterpe oleraceae), nativa da região amazônica. Com a redução na disponibilidade da juçara, muitas indústrias voltaram-se à região amazônica e passaram a extrair o palmito de açaí. 0 cultivo da pupunha pode aliviar também a pressão sobre o açaí, possibilitando que faça um manejo adequado de seu extrativismo.

\section{B) Cobrança da Água}

No tocante ao uso da água para irrigação, o modelo, ao estabelecer a cobrança, implica na busca da eficiência.

Ambientalmente esta eficiência representa a diminuição do volume de água aplicado por unidade de área. Esta redução representa uma menor disposição de sais no solo, evitando este efeito de degradação ambiental.

Além disso, a simples prática eficiente, por si só representa um abordagem ambientalmente melhor, pois poupa recursos que estariam sendo retirados da natureza apenas para complementar tal ineficiência. 


\section{C) $\mathrm{PCH}$}

Do ponto de vista da barragem, a GIR, neste caso, não apresenta diferencial ambiental em relação à abordagem convencional, uma vez que a sinergia se deu no uso e não na construção (isto partindo-se do princípio que a usina seja construída dentro de padrões sérios de preservação ambiental).

Assim sendo, não há vantagens nem desvantagens ambientais na construção da PCH por conta da abordagem da GIR.

\section{D) Avaliação Final das Vantagens}

Conforme os itens anteriores, pode-se verificar que a abordagem da GIR proporcionou vantagens em todos os aspectos: econômico, social e ambiental, dentro de parâmetros políticos e tecnológicos factíveis.

No primeiro aspecto porque facilitou a viabilização da implantação de um projeto que traz grande afluxo de capitais para a região, e que, segundo a abordagem tradicional, estava inviabilizado.

No segundo, como decorrência do primeiro, porque aumentou o nível de emprego, o PIB da região e a arrecadação de impostos pelo setor público, o que deve reverter-se em favor da sociedade.

Finalmente, no terceiro aspecto, pelas características do cultivo da pupunha, pela substituição da cultura da soja e pelo aumento dos índices sociais, mostrou-se que haverá também ganhos ambientais. 


\subsubsection{A Consideração do Caso Proposto em um Horizonte de Planejamento}

Como finalização da análise deste estudo de caso, apresentam-se aqui alguns aspectos relacionados à sua inserção em um horizonte mais longo de atuação.

O estudo anterior mostrou as vantagens de uma Gestão Integrada dos recursos, no caso a energia elétrica e a irrigação.

Mesmo assim, a despeito de tais vantagens, a área irrigada considerada pelo exemplo, 200 ha, é muito pequena em vista da área cultivável da região. Além disso, a porcentagem utilizada do rio foi de apenas $0,24 \%$.

Embora tais valores sejam realmente baixos, mostram-se adequados à alavancagem inicial do desenvolvimento regional, pois requerem o mínimo de participação do capital público (como financiamento) e baixo investimento inicial privado. No caso da utilização do rio, verifica-se que uma escolha adequada de cultura pode agregar maior valor por $\mathrm{m}^{3}$ de água utilizado, gerando benefícios sociais e econômicos, sem no entanto exaurir os recursos naturais da região.

O crescimento da atividade agrícola baseada na irrigação deve ser implementado com moderação, permitindo que se possam estabelecer parâmetros corretos para sua utilização, de forma que a natureza tenha condições de absorver adequadamente os resultados de tal atividade.

Esta abordagem poupa recursos que, certamente, serão a base para um futuro desenvolvimento sustentável da região. 
O mecanismo criado para compensação pelo uso da água, pode apresentar resultados pouco significativos inicialmente, em vista do pequeno montante de da água envolvido, mas, com o passar dos anos tenderá a se tornar mais relevante, conforme a atividade agro-industrial se desenvolva. $\mathrm{O}$ modelo de Gestão apresentado não se refere apenas ao projeto de irrigação da pupunha, mas para todas as outras captações para irrigação, que deverão ocorrer ordenadamente ao longo dos anos.

Segundo esta linha, entende-se que a completa utilização do potencial do rio para irrigação deva ocorrer no longo prazo, balizada por um planejamento bem estruturado, que contemple a melhor utilização dos recursos, da maneira mais abrangente e integrada o possível. Um exemplo de planejamento que possui tais características é o Planejamento Integrado de Recursos [Ref. 8], que já possui um arcabouço teórico bem consolidado para sua aplicação.

Um planejamento para a região deve também abranger estratégias de investimentos em novos componentes da infra-estrutura que propiciem 0 desenvolvimento de outras culturas agrícolas, outras atividades industriais, comerciais, tecnológicas etc.

A Gestão Integrada de Recursos, permite que os investimentos em infraestrutura atendam à critérios sociais e ambientais a partir do mais básico nível de desenvolvimento, como foi o do estudo de caso, e, ao longo do tempo, pode se adaptar perfeitamente à novas exigências provenientes de outros níveis mais elevados. 
O exemplo também mostrou que o cultivo da pupunha possui maior valor agregado por $\mathrm{m}^{3}$ de água utilizado.

Porque então não deixar-se de lado a $\mathrm{PCH}$ ?

A PCH é importante não apenas como financiador da barragem, conforme discutido anteriormente, mas, com uma possível (e desejada) ampliação da atividade agrícola e da irrigação será necessário um montante maior de energia elétrica, que, em determinado momento, justificará, por si só a $\mathrm{PCH}$. Durante o período em que a agricultura esteja se desenvolvendo, a $\mathrm{PCH}$ terá sua sustentação econômica baseada no mercado da região, que apresenta déficit energético. Além deste, vislumbra-se também a venda de energia para outros mercados, através da conexão com o sistema interligado. Deve-se lembrar que o desenvolvimento da indústria de palmito, além de seu próprio consumo de energia elétrica, apresenta um efeito multiplicador sobre outros setores da economia regional, o que pressionará ainda mais a demanda por esta energia.

A Gestão Integrada de Recursos é um mecanismo que deverá estar presente durante o planejamento e implementação de ações futuras, e seu conceito, voltado à sustentabilidade, deverá ser aplicado, preferencialmente, desde as etapas iniciais do desenvolvimento proposto.

Apenas como exemplo, apresenta-se a seguir a descrição de um possível plano de reinvestimento no projeto de industrialização do palmito, de forma a ampliar o projeto como um todo. 


\subsubsection{Plano de Ampliação do Projeto}

Para a ampliação do projeto, será proposto um plano de reinvestimento bienal, com recursos provenientes da lucratividade da indústria de palmito no cultivo da pupunha.

A meta será a de aproximar a produção, em um período em torno de 12 anos, ao montante de 5000 t/ano de palmito industrializado, o que corresponde à $70 \%$ do consumo anual atual da cidade de São Paulo.

A lucratividade da pupunha refere-se à diferença entre o seu custo de produção e o preço de mercado para o produto in natura, que, segundo a Tabela 5.13, é de US\$988,00/ha. Descontando-se o valor de US\$212,00/ha pago aos agricultores, tem-se o valor de US\$776,00/ha, sendo este o valor disponível para reinvestimento.

O reinvestimento será direcionado para a implantação de uma nova área cultivada, segundo o montante acumulado a cada dois anos.

Esta nova área apresentará uma lucratividade maior, pois não deverá remunerar juros do empréstimo para o capital investido, que agora é próprio.

Sendo assim, a nova lucratividade destas áreas pode ser obtida da Tabela 5.13, onde deve-se desconsiderar o pagamento da parcela de investimento. A partir daí obtém-se a nova lucratividade, que é de US\$ 1890,00/ha. O valor pago aos agricultores será aumentado na mesma proporção e passará a ser de US\$405,00/ha. A nova lucratividade da indústria de palmito será de US\$1486,00/ha. 
Após os 9 anos de pagamento do empréstimo inicial, a área inicial de 200 ha passará a apresentar esta mesma lucratividade.

Para maior clareza têm-se a Tabela 5.17.

Para a pupunha é apresentada a área inicial (área 1) e a área aumentada (área 2) bem como as respectivas lucratividades ao longo dos anos.

São também apresentados a potência instalada para a irrigação, a porcentagem de água retirada do rio e o pagamento efetuado ao Comitê de Bacia pelo uso da água. No caso, a potência instalada da irrigação (1.919kW) está próxima dos $2.500 \mathrm{~kW}$ da $\mathrm{PCH}$. Assim, um plano mais ambicioso poderia, numa primeira análise, suscitar alguma dúvida quanto à capacidade da usina de fornecer energia suficiente para bombear mais água. No entanto, deve-se lembrar aqui que a irrigação tem Fator de Carga muito baixo $(<0,20)$, e a $\mathrm{PCH}$, com potência média de $1750 \mathrm{~kW}$, poderia alimentar uma carga, com estas características, da ordem de até 8,5 MW, desde que haja um uso planejado que permita uma escalonamento da carga ao longo das horas e dos dias, o que se constitui em uma medida de Gerenciamento pelo Lado da Demanda, conforme já mencionado. 
Tabela 5.17 Reinvestimento para Ampliação do Projeto

\begin{tabular}{|c|c|c|c|c|c|c|c|c|c|c|c|}
\hline \multirow[t]{2}{*}{ Ano } & \multicolumn{7}{|c|}{ PUPUNHA IN NATURA } & \multirow{2}{*}{\begin{tabular}{|c|} 
IND. \\
PLAMITO \\
$\begin{array}{c}\text { Faturam. } \\
\text { Bruto } \\
\text { (US\$/ ano) }\end{array}$ \\
\end{tabular}} & \multicolumn{3}{|c|}{ REINVESTIMENTO } \\
\hline & \begin{tabular}{|c|} 
Área 1 \\
(Inicial) \\
(ha)
\end{tabular} & \begin{tabular}{|c|} 
Lucro 1 \\
(mil US\$/ \\
ha/ ano)
\end{tabular} & $\begin{array}{c}\text { Área 2 } \\
\text { (Ampliada) } \\
\text { (ha) }\end{array}$ & \begin{tabular}{|c|} 
Lucro 2 \\
(mil US\$/ \\
ha/ ano)
\end{tabular} & \begin{tabular}{|c|}
$\%$ água \\
retirada \\
do rio
\end{tabular} & $\begin{array}{l}\text { Valor do } \\
\text { Uso água } \\
\text { (mil } \\
\text { US\$/ ano) }\end{array}$ & \begin{tabular}{|c|} 
Pot. Inst. \\
(kW)
\end{tabular} & & \begin{tabular}{|c|}
$\begin{array}{c}\text { Pupunha } \\
\text { (mil US\$/ } \\
\text { ano) }\end{array}$ \\
\end{tabular} & $\begin{array}{c}\text { Total } \\
2 \text { anos } \\
\text { (mil US\$/ } \\
\text { ano) }\end{array}$ & $\begin{array}{l}\text { Nova } \\
\text { Área } \\
\text { (ha) }\end{array}$ \\
\hline 1 & 200 & 0 & 0 & 0 & 0,24 & 4,16 & 308 & 4.160 .000 & 0 & & 0 \\
\hline 2 & 200 & 151 & 0 & 0 & 0,24 & 4,16 & 308 & 4.160 .000 & 151 & 151 & 31 \\
\hline 3 & 200 & 151 & 31 & 0 & 0,28 & 4,80 & 356 & 4.804 .800 & 151 & & 0 \\
\hline 4 & 200 & 151 & 31 & 44 & 0,28 & 4,80 & 356 & 4.804 .800 & 195 & 346 & 72 \\
\hline 5 & 200 & 151 & 103 & 44 & 0,36 & 6,30 & 467 & 6.302 .400 & 195 & & 0 \\
\hline 6 & 200 & 151 & 103 & 147 & 0,36 & 6,30 & 467 & 6.302 .400 & 298 & 493 & 102 \\
\hline 7 & 200 & 151 & 205 & 147 & 0,49 & 8,42 & 624 & 8.424 .000 & 298 & & 0 \\
\hline 8 & 200 & 151 & 205 & 292 & 0,49 & 8,42 & 624 & 8.424 .000 & 443 & 741 & 154 \\
\hline 9 & 200 & 151 & 359 & 292 & 0,67 & 11,63 & 861 & 11.627 .200 & 443 & & 0 \\
\hline 10 & 200 & 285,2 & 359 & 512 & 0,67 & 11,63 & 861 & 11.627 .200 & 797 & 1240 & 257 \\
\hline 11 & 200 & 285,2 & 616 & 512 & 0,98 & 16,97 & 1257 & 16.972 .800 & 797 & & 0 \\
\hline 12 & 200 & 285,2 & 616 & 878 & 0,98 & 16,97 & 1257 & 16.972 .800 & 1164 & 1961 & 407 \\
\hline 13 & 200 & 285,2 & 1023 & 878 & 1,47 & 25,44 & 1883 & 25.438 .400 & 1164 & & 0 \\
\hline 14 & 200 & 285,2 & 1023 & 1459 & 1,47 & 25,44 & 1883 & 25.438 .400 & 1744 & 2908 & 603 \\
\hline
\end{tabular}

Para que seja possível tal ampliação, em termos de área cultivada, seria necessário que o projeto ultrapassasse os limites de um único município, o que proporcionaria um desenvolvimento mais uniforme na região.

A Tabela 5.17 permite visualizar como, a partir de um pequeno investimento inicial (facilitado pela GIR), é possível alcançar-se o desenvolvimento na região, dado o alto valor movimentado pela agroindústria.

Nota-se também que, ao final de 14 anos, é possível atingir-se a área cultivada de 1246 ha, com uma produção de 4.984 t/ano de palmito. O valor anual movimentado, apenas por esta indústria, é da ordem de US\$26 milhões. O pagamento efetuado aos agricultores, sofreria um aumento, em dólares, da ordem de $90 \%$. 
Para que se atinjam tais cifras, é necessária a retirada de 1,5\% da água do rio, o que representaria um pagamento próximo de US\$26.000,00/ano ao Comitê de Bacia. Este valor de retirada evidencia que o desenvolvimento da região pode ser alcançado de forma a preservar os recursos naturais de que se dispõem.

A potência instalada para irrigação ficaria próxima de $2 \mathrm{MW}$, e representaria menos de um quarto da capacidade que a $\mathrm{PCH}$ apresenta para este fim. Vale lembrar que, paralelamente à esta atividade estarão se desenvolvendo outros setores da economia e a própria instalação da indústria de palmito.

Além disso, deve-se buscar o desenvolvimento de outras atividades agrícolas e industriais para a região, que, com o afluxo de capitais proporcionado pelo projeto inicial, passaria a ter meios para implementar melhoras na infra-estrutura local, o que propiciaria o aparecimento de outros tipos de atividades produtivas mais sofisticadas.

Embora trate-se de um exemplo simples de atuação no longo prazo, permite verificar que a GIR proporciona condições iniciais para a alavancagem do desenvolvimento de uma região compatíveis com os posteriores desdobramentos do mesmo.

Tais condições são criadas a partir de parâmetros de factibilidade relativos às características locais e em conformidade com a proposta inicial de atuação pública e privada, com vistas ao desenvolvimento sustentável. 
A extensão do modelo para o longo prazo mostra que o mesmo continua válido e, mais do que isso, tem importância crescente ao longo do tempo, principalmente sob o ponto de vista da sustentabilidade. 


\section{CONCLUSÕES E RECOMENDAÇÕES}

De maneira geral, e de acordo com o que se pôde concluir ao longo do texto, pode-se destacar os seguintes aspectos referentes à provisão de infraestrutura segundo os preceitos da GIR:

- A GIR é necessária como uma ferramenta que permite a harmonização dos aspectos institucionais e empresariais envolvidos na provisão da infra-estrutura;

- Sua abordagem deve deixar clara a necessidade de participação de todos os entes envolvidos e afetados e o papel de cada um;

- O Estado deve, cada vez mais, participar ativamente do processo de provisão da infra-estrutura, só que segundo o papel de regulador, estabelecendo e garantindo o cumprimento de critérios sociais e ambientais, com vistas ao desenvolvimento sustentável. Através deste papel também deve ser estabelecido o novo paradigma de obtenção de recursos financeiros, ou seja, através de mecanismos diferenciados que proporcionem o investimento do setor privado na provisão da infraestrutura;

- Outro aspecto a ser destacado é que o processo deve ser procedido sob a ótica da busca da sustentabilidade, o que exige medidas, muitas vezes, de pouca aceitação. Neste ponto identifica-se como necessária a participação da sociedade no processo de elaboração da GIR, o que no estudo de caso aconteceu através dos Comitês de Bacia; 
- Também deve-se destacar que, a despeito do novo paradigma com ênfase no Estado Regulador, este ainda é necessário como financiador, como acontece inclusive nos países desenvolvidos, principalmente em atividades como a agricultura. Mesmo assim, através da GIR obteve-se um incremento significativo na arrecadação de impostos, mostrando também que há benefícios financeiros para o Estado. Esta participação é válida desde que tal participação aconteça apenas como um fator de alavancagem inicial, permitindo investimentos de maior porte, provenientes do setor privado;

- Evidencia-se também a necessidade de um processo de planejamento abrangente e igualmente integrado, que permita aos investidores e demais participantes enxergarem novas oportunidades de negócios, normalmente não disponíveis em uma visão fracionada da provisão de infra-estrutura. Esta necessidade evidencia-se pelo fato de que a GIR, que é voltada à ações (momento), é melhor procedida se estiver sob encaminhamento de uma visão abrangente e de longo prazo, necessária à efetiva busca da sustentabilidade. Para tanto, os governantes devem estar atentos para o novo papel do Estado, e devem tomar suas decisões de momento, balizadas por esta visão de longo prazo;

- A energia elétrica, conforme mencionado, tem papel preponderante no fomento do desenvolvimento, e, quando inserida no contexto mais amplo da infra-estrutura, pode ter sua disponibilização facilitada e inclusive compatibilizada com interesses que, de outra forma, seriam 
conflitantes. No estudo de caso, a implantação da PCH foi facilitada por estar inserida em uma visão que contemplou o uso da água para os outros usos, e que pôde valorar o benefício da construção da barragem também para tais usos.

- Finalmente poderia-se dizer que a Gestão Integrada de Recursos permite a viabilização de um processo onde "todos ganham", pois a sociedade passa a ter acesso à infra-estrutura, o setor privado passa a contar com novas oportunidades de negócios e o Estado, através da regulação, cumpre seu papel com a coletividade, buscando garantir o acesso da população carente à infra-estrutura e melhorando as condições ambientais. 


\section{Referências Bibliográficas}

[1] WORLD BANK; "World Development Report - Infrastructure for Development", , Cambrige University Press, New York, USA, 1994.

[2] REIS, L. B.; "Geração de Energia Elétrica"; Editora Tec Art, São Paulo, 1998.

[3] REIS, L. B., SILVEIRA, S., et ali; "Energia Elétrica Para Um Desenvolvimento Sustentável "; Edição do LAIS - Latin American Institute - Stockholm University e GEPEA - Grupo de Energia do Departamento de Engenharia de Energia e Automação Elétricas da Escola Politécnica da Universidade de São Paulo, Edusp, São Paulo, 2000.

[4] REIS; L. B.; MIELNICK, O.; "Um Modelo de Gestão Integrada de Recursos para Viabilizar o Desenvolvimento Sustentável", Artigo em fase de publicação, constante no ANEXO 1, Escola Politécnica da USP, São Paulo, 1999.

[5] BRAGA; P. F. B.; CONEJO, J. G. L.; BARROS, M. T. L. ; et ali; "Introdução à Engenharia Ambiental"; apostila do Departamento de Engenharia Hidráulica e Sanitária da Escola Politécnica da Universidade de São Paulo, 1994.

[6] REIS, L. B., "Usinas Hidrelétricas com Rotação Variável - Opção Energética Para Longa Distância, Aproveitamentos de Pequeno Porte e Reversíveis", Tese para obtenção do título de Professor Livre Docente junto ao Departamento de Engenharia de Energia e Automação Elétricas da Escola Politécnica da Universidade de São Paulo, 1993.

[7] TASINATO, P. M. ; "Regulação de Geradores de Fluxo pela Variação da Rotação", dissertação de mestrado apresentada à Escola Federal de engenharia de Itajubá, Itajubá, 1998.

[8] UDAETA, M. E. M.; 'Planejamento Integrado de Recursos (PIR) para o Setor Elétrico (pensando o desenvolvimento sustentável)', tese de doutorado, São Paulo - SP, EPUSP - Departamento de Engenharia de Energia e Automação Elétricas, 1997.

[9] GOLDEMBERG, J.; "Energia, Meio Ambiente \& Desenvolvimento"; Edusp, Editora da Universidade de São Paulo, São Paulo, 1998.

[10]LYNCH, R. P.; "Alianças de Negócios - Uma Arma Secreta, Inovadora e Oculta para Vantagens Competitivas", Editora McGraw Hill, São Paulo, 1994.

[11] VIANNA, M. A. F.; VELASCO, S. D.; "Futuro: Prepare-se!", Ed. Gente, segunda edição, São Paulo, 1998. 
[12] REIS, L. B.; GALVÃO, L. C. R.; CARVALHO, C. E.; "Planejamento da Integração Energética Voltado ao Desenvolvimento Sustentável, com Ênfase às Interligações Elétricas", III Congresso Brasileiro de Planejamento Energético, São Paulo de 22 a 25 de junho de 1998.

[13] MAKRIDAKIS, S., "Management in the 21st Century", Artigo extraído do livro Facing Up to the Future: In Search of Pragmatism in Management, Free Press, New York, USA, 1989.

[14] SHERMAN, A.; GREENO, J. L; ROSS, C. E. ; "Planejamento de Cenários", Revista HSM Management, $\mathrm{n}^{\circ} 11$, ano 2, páginas 100 a 110, Barueri SP, novembro-dezembro de 1998.

[15] CARVALHO, C. E., UDAETA, M. E. M., REIS, L. B. R., CHIAN, C. C. T.; "Análise teórica da aplicação do Planejamento Integrado de Recursos em uma área rural para a produção de termofosfatos em pequena escala", XVI Conferência Internacional de Eletrificação Rural - CLER, Santiago, Chile, Setembro, 1997.

[16] THE INSTITUTION OF CIVIL ENGINEERS; "Sustainability \& Acceptability In Infrastructure Development"; Thomas Telford Publishing, London, UK, 1996.

[17] ABCE - Associação Brasileira de Concessionárias de Energia Elétrica, "Uso Múltiplo das Águas - Gestão de Recursos Hídricos, envolvimento dos Municípios", Simpósio, São Paulo, de 05 a 06 de outubro de 1999.

[18] IBGE - INSTITUTO BRASILEIRO DE GEOGRAFIA E ESTATÍSTICA; "Índices sociais Mínimos", http://www.ibge.gov.br, Rio de Janeiro, 1997.

[19] JAMES, D.; " The Application of Economic Techniques in Environmental Impact Assesment", Kluwer Academic Publishers, Dordrecht, Netherlands, 1994.

[20] PIERONI, F. P.; GUERRA, S. M. G.; "Implantação do Gasoduto Bolívia - Brasil - A Geração de Empregos Segundo a Matriz de Leontief", trabalho de formatura apresentado à Universidade Estadual de Campinas Faculdade de Engenharia Mecânica Departamento de Energia, Campinas, julho de 1999.

[21] CARVALHO, C.E., CHIAN, C.C.T. "Avaliação dos Custos Completos dos Recursos Energéticos na Produção Integrada de Termofosfatos no Médio Paranapanema" Projeto de Formatura apresentado à EPUSP, São Paulo,1997.

[22] UDAETA, M. E. M.; "Levantamento de Dados sobre a Região do Médio Paranapanema", Grupo de Energia do Departamento de Engenharia de Energia e Automação Elétricas da EPUSP, São Paulo, 1999. 
[23] FUKUDA, F., 'Sistema de Informações Para Análise Geoenergética (SAGe) - (Informações Energéticas Referenciadas Geograficamente da Região do Médio Paranapanema), projeto de formatura 1996, São Paulo - SP, EPUSP- Departamento de Engenharia de Energia e Automação Elétricas, 1996.

[24] EHRLICH, P. J.;"Engenharia Econômica - Avaliação e Seleção de Projetos de Investimento", Editora Atlas, $5^{\circ}$ edição, São Paulo, 1989.

[25] ELETROBRÁS; "Manual de Inventário Hidrelétrico", http://www.eletrobras.gov.br, Biblioteca Virtual, 1999.

[26] ELETROBRÁS; "Plano Decenal de Expansão 1999 - 2008", http://www.eletrobras.gov.br, Biblioteca Virtual, 1999.

[27] ANEEL; "Tarifas Medidas por classe de Consumo - Regional e Brasil", http://www.aneel.gov.br, 1999.

[28] REIS; L. B.; "Oportunidades de Geração Termelétrica no Setor Elétrico Brasileiro e Metodologias para Avaliação de Viabilidade ", estudo do GEPEA, Escola Politécnica da USP, São Paulo, 1999.

[29] GIMENES, A. L. V.; GALVÃO, L. C. R.; REIS, L. B.; UDAETA, M. E .M. "Proposta de Gerenciamento Pelo Lado da Demanda Visando o Desenvolvimento Sustentado para a Região do Médio Paranapanema - MPP". SENESE X - Congresso Internacional de Energias Sustentables, Punta Arenas - Chile, 18 a 20 de novembro de 1998.

[30] GIMENES, A. L. V.; BONZOI, E. E.; "Gerenciamento Pelo Lado da Demanda para a Região do Médio Paranapanema - MPP", Projeto de Formatura apresentado à EPUSP, São Paulo,1997.

[31] PROGRAMA DAS NAÇÕES UNIDAS PARA O DESENVOLVIMENTO PNUD; " PROJETO BRA/94/016 - Área Temática: Agricultura Sustentável", Consórcio Museu Emílio Goeldi, MPEG, USPPROCAM, ATECH, texto para Workshop de janeiro de 1999.

[32] DIEHL, S. R. L.; JUNQUETTI, M. T. G.; "Soja - Manual das Culturas CATI Centro de Informações Agropecuárias" http://www.cati.sp.gov.br/tecnologias/culturas/soja.html, CIAGRO/CATI, Campinas.

[33] FERREIRA, L. G. S; "Pupunha - Manual das Culturas CATI Centro de Informações Agropecuárias"

http://www.cati.sp.gov.br/tecnologias/culturas/pupunha.html, CIAGRO/CATI, Campinas.

[34] MARTINHO, P. R. R.; DIAS, H. S.; CALHEIROS, R. O.; PEREIRA, A. D.; SAKAI, E.; ARRUDA, F. B.; OKAWA, H.; CARVALHO, Y. M. C.; 
"Projeto A.E.D.A.S - Área Experimental e Demonstrativa de Agricultura Sustentável", Médio Paranapanema, Centro de Desenvolvimento do Vale do Paranapanema - CDVale, Instituto Agronômico - IAC, Instituto de Economia Agrícola - IEA, Assis, SP, 1999.

[35] AGRO-FAUNA Com. de Insumos Ltda; "Palmito Pupunha - (Bactris gasipaes Kunth.)" $\quad$ - http://www.agrofauna.com/palmito_pupunha.htm, 1997-98.

[36] LIMA, A. F; "Projeto Pupunha, o Palmito Ecológico de São Tomé", Prefeitura do Município de São Tomé. Co-Participantes: EMATER-PR, IAPAR, IAP, APROMAC. http://www.apromac.org.br/pupunha.htm, São Tomé - PR, 1998.

[37] NETO, R. F. V.; Meleiro, M.; "Pupunha", CATI Responde, Regional de São Paulo, http://www.cati.sp.gov.br/dct/PUPUNHA.html.

[38] YUYAMA, K.; "Sistemas de cultivo para produção de palmito da pupunheira", in A Revista da Pupunha, http://peixeboi.inpa.gov.br/pupunha/artigos.html, Horticultura Brasileira, suplemento pág. 191-198. 1997.

[39] BOVI, M. L. A.; "Expansão do cultivo da pupunheira para palmito no Brasil", in A Revista da Pupunha, http://peixeboi.inpa.gov.br/pupunha/artigos.html, IAC Horticultura Brasileira, suplemento pág. 183-185. 1997.

[40] BONACCINI, L.; "O Mercado Nacional e Internacional de Palmito", 10. Seminário do Agronegócio Palmito de Pupunha na Amazônia, Porto Velho, 11 de Agosto de 1.999. http://sites.uol.com.br/bonaccini/estrat.htm.

[41] LIMA G. B. N.; Carvalho G. R.; Maluf, W. R.; "Cultivo de Palmito de Pupunha", Boletim Técnico de Hortaliças No 22, 1a edição, http://www2.ufla.br/ wrmaluf/bth022/bth022.html, Universidade Federal de Lavras - UFLA, Março de 1999.

[42] HERNANDEZ, F. B. T. ; "Sistemas de Irrigação para Todos os Fins Aplicações dos sistemas e exame dos avanços na irrigação", Agribusiness Worldwide, v. 11, n. 6, p. 20-30, http://www.agr.feis.unesp.br/sistemas.htm, 1989.

[43] HERNANDEZ, F. B. T. ; "Irrigação na Cultura da Pupunha no Noroeste Paulista" UNESP" http://www.agr.feis.unesp.br/aracatuba.htm, Palestra proferida no SIRAN, Araçatuba, 29 de maio de 1999.

[44] UNICAMP,

"6.

Extração

de

Palmito", http://www.unicamp.br/nipe/rbma/pal_exp.htm, documento disponível na página eletrônica sem data, Campinas, SP. 
[45] MINISTÉRIO DA AGRICULTURA; "Plano Agrícola - 1999/2000 " http://www.agricultura.gov.br/, 1999.

[46] CONTETO; http://clockworktec.com.br/contetocombr/docs.htm, 1999.

"Impostos",

[47] RECEITA FEDERAL;

http://www.receita.fazenda.gov.br, 1999.

Jurídica", 


\title{
ANEXO1 \\ UM MODELO DE GESTÃO INTEGRADA DE RECURSOS PARA VIABILIZAR O DESENVOLVIMENTO REGIONAL SUSTENTÁVEL
}

\author{
Lineu Belico dos Reis
}

Octavio Mielnick

\section{INTRODUCÃO}

O estabelecimento de uma estratégia adequada para a utilização de recursos de infra-estrutura disponíveis é uma necessidade fundamental para o desenvolvimento de uma determinada área, seja ela um continente, um país ou uma região. Além disso, a utilização destes recursos de uma forma integrada e harmoniosa com os componentes ambientais e sociais é um requerimento fundamental para que haja sustentabilidade no processo de desenvolvimento. A utilização equilibrada dos vários recursos de infra-estrutura--associando critérios econômicos, sociais e ambientais em uma gestão conjunta--representa uma alternativa que promove a melhor distribuição dos recursos (na abordagem dos bens públicos) e oferece uma nova oportunidade de negócios (na perspectiva do setor privado).

O objetivo do modelo da gestão integrada de recursos é permitir a viabilização de processos sustentáveis de desenvolvimento, por meio do estabelecimento dos mecanismos operacionais que viabilizem a utilização integrada e harmoniosa de recursos. Entende-se que estes mecanismos sejam estabelecidos dentro do contexto atual de desenvolvimento e de orientação dos investimentos privados. O modelo da gestão integrada de recursos visa, principalmente, as regiões onde, nas condições atuais, prevalecendo avaliações econômicas setorializadas --em detrimento de critérios que associem aspectos técnicos, econômicos, sociais e ambientais--não se consegue atrair os investimentos necessários para a implantação de empresas privadas para o funcionamento dos serviços de infra-estrutura. 
No processo de reestruturação dos serviços de infra-estrutura no Brasil, as áreas com menor produto econômico, cuja população apresente menor poder aquisitivo, tendem a ser desprezadas pelos investidores privados, agravando as disparidades existentes e dificultando a melhoria das condições gerais de atividade pela implantação de melhores serviços de infra-estrutura. Pelos mecanismos adotados anteriormente, esse impasse acabaria dando lugar à concessão de subsídios, permitindo, desse modo, um acesso precário das populações dessas regiões aos serviços de infra-estrutura sem viabilizar a melhoria qualitativa em suas atividades. Os novos critérios operacionais a serem propostos pelo modelo da gestão integrada de recursos terão, por referência, as oportunidades oferecidas pela nova ordem, baseada em (1) reorganização institucional dos setores relacionados à infra-estrutura (energia, transportes, telecomunicações, água e saneamento básico); (2) incentivo à aplicação de capitais privados nos mesmos setores e (3) criação das agências reguladoras, cuja missão é, entre outras coisas, a de assegurar a qualidade dos serviços públicos em benefício da população e a de viabilizar projetos de interesse público, por critérios que preservem os interesses do conjunto dos participantes, incluindo os órgãos governamentais, as empresas e os seus investidores.

O modelo contempla mecanismos operacionais técnicos, econômicos e regulatórios que permitem a Gestão Integrada dos Recursos em uma região, de modo a viabilizar o seu desenvolvimento nas condições atuais do processo de reestruturação dos serviços de infra-estrutura. Estes mecanismos serão orientados à exploração de sinergias geradas pela formação de consórcios de empresas atuando nos diversos setores de infra-estrutura, obedecendo a critérios comuns de gestão.

\section{A NECESSIDADE DE UM MOdELO DE GESTÃo INTEGRADA DE RECURSOS}

As principais razões que justificam o modelo de gestão integrada de recursos, são: 
(1) A importância de estabelecer-se mecanismos que incentivem a utilização integrada e mais adequada dos recursos disponíveis em uma dada região, de forma a estabelecer uma estratégia de desenvolvimento sustentável, que elimine desperdícios, se harmonize com o meio ambiente, promova a equidade e seja adequada às condicionantes políticas do momento.

(2) A necessidade de uma visão holística e multidisciplinar dos principais vetores de infra-estrutura relacionados com o desenvolvimento e sua sustentabilidade: energia, telecomunicações, transporte, água e saneamento básico.

(3) A necessidade de viabilizar a aplicação de conceitos que relacionem a utilização integrada de recursos, a exploração de sinergias potenciais e o desenvolvimento sustentável, de uma forma prática e atrativa para investidores privados.

(4) O processo de reestruturação e de reforma institucional dos serviços públicos de infra-estrutura no País, o que cria oportunidades para a introdução de novos debates, procedimentos e propostas

(5) A identificação, no País, de diversas áreas e regiões, onde o desenvolvimento tem sido inviabilizado, principalmente por falta de investimentos nos serviços de infra-estrutura, resultando em menos investimentos e em redução cada vez mais acentuada da atividade econômica.

(6) A viabilização da possibilidade de estabelecer unidades de negócio em consórcio, com gestão unificada, permitindo a utilização integrada dos recursos da região de modo que o melhor uso dos recursos (interesse da comunidade) esteja associado a oportunidades atrativas aos investidores privados. 


\section{CONCEPÇÃO BÁSICA DO MODELO}

Em sua concepção geral, o modelo visa estabelecer mecanismos operacionais técnicos, econômicos e regulatórios que permitam a Gestão Integrada dos Recursos em uma região, de modo a viabilizar o seu desenvolvimento nas condições atuais do processo de reestruturação dos serviços públicos de infraestrutura.

Esta concepção traz, em seu bojo, os seguintes objetivos específicos

- A criação de mecanismos para incentivar o aproveitamento integrado de recursos regionais e o desenvolvimento sustentável por meio do estabelecimento de oportunidades de negócios.

O estabelecimento de métodos e procedimentos para o planejamento, implementação e controle de projetos desenvolvidos com base na integração de recursos e desenvolvimento sustentável. Este arcabouço metodológico é fundamental para a Gestão Integrada de Recursos, permitindo a clara identificação de custos e benefícios setoriais (ou por atores envolvidos) e das responsabilidades e participações dos envolvidos, tanto nos procedimentos decisórios como na implementação e operação dos projetos.

O estabelecimento de mecanismos regulatórios que permitam a superação de barreiras econômicas e financeiras, criando condições para que a utilização integrada dos recursos tenha lugar por meio de uma gestão privada unificada dos serviços públicos de infra-estrutura.

De uma certa forma, esta concepção, quando aplicada a uma determinada região, vai resultar em que o modelo apresente uma série de características específicas da região abordada. 
Assim, é importante que se apresente a metodologia de desenvolvimento do modelo, esta sim de caráter geral, que incorporará, à medida em que se desenvolve as referidas características específicas.

\section{A METODOLOGIA DE DESENVOLVIMENTO DO MODELO DE GESTÃO INTEGRADA DE RECURSOS PARA UMA DADA REGIÃO}

\section{1 - Descrição Geral}

O fundamento básico do modelo é a aplicação do conceito de Distribuição Integrada de Recursos--desenvolvido com base na aplicação do Planejamento Integrado de Recursos aos sistemas de distribuição de energia elétrica com Geração Distribuída--ao funcionamento dos serviços de infra-estrutura em uma região. De fato, a Distribuição Integrada de Recursos se relaciona com o melhor uso integrado dos recursos de infra-estrutura, considerando os aspectos relativos à sua viabilização e, principalmente, à sua distribuição por toda a região.

A metodologia geral de desenvolvimento do modelo baseia-se na determinação do melhor modo de convivência dos interesses da gestão empresarial com os dos agentes regulatórios para viabilizar e incentivar estratégias de desenvolvimento estabelecidas por meio dos métodos da Distribuição Integrada de Recursos. Estas estratégias servirão de base para 0 estabelecimento de mecanismos para operacionalizar a Gestão Integrada de Recursos a partir do amálgama de duas concepções: (1) a visão empresarial, que pretende a realização do lucro, considerando o papel e as atribuições dos investidores; (2) a visão institucional, com ênfase na defesa dos interesses coletivos e na atuação dos agentes reguladores dos serviços de infra-estrutura.

O objetivo final é a busca do equilíbrio dos pontos concordantes e discordantes destas duas visões e o estabelecimento de procedimentos de negociação de conflitos que permitam sua harmonização ao longo do tempo. Para isso, as 
visões empresarial e institucional devem debruçar-se sobre um modelo de integração de recursos e de sua gestão, contendo duas concepções básicas :

- uma concepção técnica, com enfoque central no consumidor e na sustentabilidade, que deverá orientar a construção de um arcabouço metodológico para permitir o desenvolvimento, monitoração e controle de projetos associados à utilização integrada de recursos;

- uma concepção econômica, com enfoque empresarial, que deverá orientar o estabelecimento de mecanismos que permitam a gestão integrada privada dos mesmos recursos.

\section{2 - Descrição da metodologia}

A Gestão Integrada de Recursos será estabelecida por meio de uma avaliação integrada dos aspectos institucionais e empresariais sobre alternativas de desenvolvimento vinculadas à Distribuição Integrada de Recursos.

Do ponto de vista institucional, o enfoque se dará sobre a atuação dos agentes reguladores dos serviços de infra-estrutura, os quais--em um mercado competitivo--têm, entre outras, as funções de zelar pela preservação das regras da competição e de preservar os interesses da comunidade. $O$ estabelecimento de projetos de interesse público, ao mesmo tempo em que resguardam os interesses dos entes participantes no projeto em si, é o tipo de ação que se visualiza no caso da Gestão Integrada de Recursos: o incentivo, a catálise, a criação de mecanismos. Sob este aspecto, o projeto deverá considerar a regulação dos serviços de infra-estrutura, com o objetivo de identificar e sugerir rumos de atuação que levem aos objetivos acima citados.

Do ponto de vista empresarial, a abordagem considerará os investidores privados, cuja principal motivação é a obtenção de lucros e demais benefícios associados aos investimentos. Considerando que o modelo vai considerar regiões que não são atrativas para cada empresa--considerada individualmente--é fundamental demonstrar a possibilidade de obtenção de 
ganhos por meio da formação de consórcios de empresas e de sua gestão unificada. O projeto deverá indicar os meios para realizar-se esta demonstração, a partir dos resultados da análise da Distribuição Integrada de Recursos, assim como detalhar possíveis relações entre cada empresa e os seus investidores e a exploração das sinergias potenciais entre o conjunto das empresas envolvidas no contexto da Gestão Integrada de Recursos.

Com relação às alternativas associadas à Distribuição Integrada de Recursos, o projeto tratará, basicamente, dos aspectos técnicos e econômicos, abordando as ações resultantes da Concepção Técnica e da Concepção Econômica destas alternativas. A metodologia para o desenvolvimento desta concepções se desenvolverá a partir de algumas premissas básicas, de que se trata a seguir.

\section{3 - Concepção Técnica}

A concepção técnica das alternativas de desenvolvimento associadas à Gestão Integrada de Recursos será baseada nas seguintes premissas :

- Utilização e Distribuição Integrada dos Recursos: energia, transportes, telecomunicações, água e saneamento básico. Estes recursos apresentam as seguintes características, que fortalecem o seu tratamento integrado:

\footnotetext{
$>\quad$ envolvem redes de distribuição;

$>\quad$ são serviços públicos, portanto operados sob regime de concessão;
}

$>$ formam, no conjunto, a infra-estrutura para o desenvolvimento. 
- A comunidade-alvo é uma região. A aplicação se dará, então, em escala regional, privilegiando regiões menos atrativas, do ponto de vista de cada empresa individualmente, mas apresentando potencial econômico de desenvolvimento.

- A Gestão Integrada de Recursos deverá viabilizar um atendimento alternativo a estas regiões, nas quais os critérios convencionais de administração privada não encontram aplicabilidade.

\section{4 - Concepcão Econômica}

A concepção econômica estará baseadas nos seguintes componentes estratégicos para a ação de investidores privados:

- A Gestão Integrada de Recursos tem por objetivo a obtenção de lucros em atividades nas quais, individualmente, as empresas não teriam estimulo para realizar investimentos; no entanto, a articulação de várias empresas--explorando as sinergias resultantes da associação de suas vantagens individuais--em uma gestão unificada dos serviços públicos de infra-estrutura de uma região deverá torná-la um mercado atrativo.

- $\quad$ Atividades envolvendo a distribuição de serviços públicos de infraestrutura devem promover economias de escala, ampliando os benefícios advindos da utilização de canais comuns nas diversas cidades e comunidades da região.

- A Gestão Integrada de Recursos servirá como suporte para a criação de novas oportunidades e de novos negócios possibilitados pela realização dos serviços de infra-estrutura. 